Portland State University

PDXScholar

7-8-2002

\title{
Comparison of Heat Output and Microchemical Changes of Palladium Cathodes under Electrolysis in Acidified Light and Heavy Water
}

Conrado Salas Cano

Portland State University

Follow this and additional works at: https://pdxscholar.library.pdx.edu/open_access_etds

Part of the Physics Commons

Let us know how access to this document benefits you.

\section{Recommended Citation}

Salas Cano, Conrado, "Comparison of Heat Output and Microchemical Changes of Palladium Cathodes under Electrolysis in Acidified Light and Heavy Water" (2002). Dissertations and Theses. Paper 4616. https://doi.org/10.15760/etd.6500

This Thesis is brought to you for free and open access. It has been accepted for inclusion in Dissertations and Theses by an authorized administrator of PDXScholar. Please contact us if we can make this document more accessible: pdxscholar@pdx.edu. 


\section{THESIS APPROVAL}

The abstract and thesis of Conrado Salas Cano for the Master of Science in Physics were presented July 8, 2002 and accepted by the thesis committee and the department.

COMMITTEE APPROVALS:

John Dash, Chair

Pavel Smejtek

Robert O'Brien

Representative of the Office of Graduate Studies

DEPARTMENT APPROVAL:

Erik Bodegom, Chair

Department of Physics 


\begin{abstract}
An abstract of the thesis of Conrado Salas Cano for the Master of Science in Physics presented July 8, 2002.
\end{abstract}

Title: Comparison of Heat Output and Microchemical Changes of Palladium Cathodes under Electrolysis in Acidified Light and Heavy Water.

Two experiments have been conducted to ascertain if a cell with a palladium cathode, a platinum anode, and a solution of $\mathrm{H}_{2} \mathrm{SO}_{4}$ in $\mathrm{D}_{2} \mathrm{O}$ can produce excess heat under electrolysis compared to a similar cell with $\mathrm{H}_{2} \mathrm{O}$. In each experiment, two cells were connected in series with constant current. The two cells were identical except for the fact that the heavy water cell used $\mathrm{D}_{2} \mathrm{O}$ instead of $\mathrm{H}_{2} \mathrm{O}$ in the electrolyte. Both cells in each experiment employed Pd cathodes, Pt anodes, and $\mathrm{H}_{2} \mathrm{SO}_{4}$ in the solution.

On a piece of Pd foil that had been cold-rolled and cleaned like the cathodes but had not been electrolyzed, scanning electron microscopy (SEM) and energy dispersive spectrometry (EDS) failed to find any traces of unexpected elements. 
In the first experiment the indication was that the light water cell was slightly warmer despite receiving slightly less power. Small amounts of silver were found on both cathodes after electrolysis.

In the second experiment, the $\mathrm{D}_{2} \mathrm{O}$ cell produced an excess heat relative to the $\mathrm{H}_{2} \mathrm{O}$ cell that was too large by at least an order of magnitude to be explainable by chemical reactions or mechanical artifacts.

After electrolysis, it was found that $\mathrm{Cd}$ was present on the surface of the $\mathrm{H}_{2} \mathrm{O}$ cathode at levels of concentration that were variable but generally no less than $4 \%$ relative to $\mathrm{Pd}$ (above $3 \sigma$ ). The $\mathrm{H}_{2} \mathrm{O}$ cathode of this second experiment finished electrolysis very straight.

The $\mathrm{D}_{2} \mathrm{O}$ cell cathode finished severely arched $\left(\sim 30^{\circ}\right)$, with its convex side facing the anode, and covered in a deposit of powdery black substance which was most likely $\mathrm{PdS}$ formed accidentally on the first day of this experiment when the $\mathrm{D}_{2} \mathrm{O}$ cell had been run with the wrong polarity. On this $\mathrm{D}_{2} \mathrm{O}$ cell cathode, no statistically significant traces of $\mathrm{Cd}$ were detected but $\mathrm{Ag}$ was present in 2-5\% concentration relative to $\mathrm{Pd}$. In some spots, the $\mathrm{Ag}$ abundance surpassed $20 \%$ that of $\mathrm{Pd}$. The most likely explanation is neutron-induced nuclear transmutation of some of the $\mathrm{Pd}$ nuclides with direct release of heat into the solid-state lattice. 
COMPARISON OF HEAT OUTPUT AND MICROCHEMICAL CHANGES OF PALLADIUM CATHODES UNDER ELECTROLYSIS IN ACIDIFIED LIGHT AND HEAVY WATER

\author{
by \\ Conrado Salas Cano
}

A thesis submitted in partial fulfillment of the requirements for the degree of

\title{
MASTER OF SCIENCE \\ in \\ PHYSICS
}

Portland State University

2002 


\section{ACKNOWLEDGMENT}

There is no end to the persons I would like to thank.

First and foremost, I would like to thank my parents, for their unfathomable patience and support. They truly have given me everything I am.

Next, I would like to thank David Icke, whose words set me free and gave me the courage to face with enthusiasm the challenges of life.

My acknowledgement of John Dash goes also beyond the academic and the professional into the personal. Working with him has been a learning experience at all levels. Without his patience and support I would truly not have gone past hooking up the first thermocouple.

I would like to thank too the endearing help and advice I have received from John Warner, Hideo Kozima, Leroy Laush the Silicon God, Marc Nisenfeld, Steve Kaplan, Brian O'Leary, and countless others I have met along the way. I am also very thankful to Pavel Smejtek and Robert O'Brien for their invaluable comments and suggestions.

This work was supported by the New York Community Trust. 


\section{TABLE OF CONTENTS}

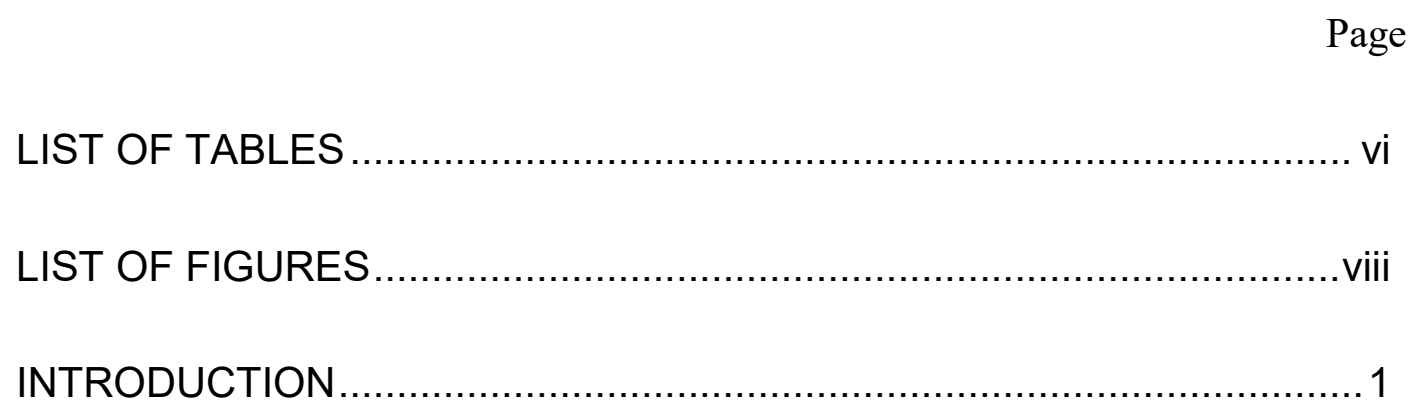

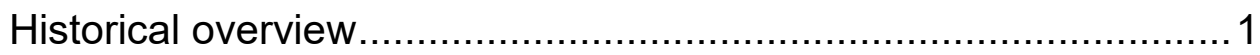

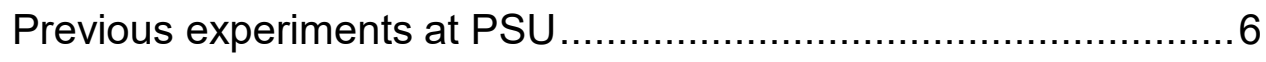

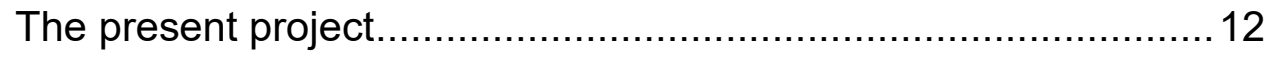

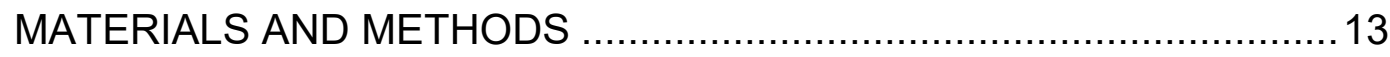

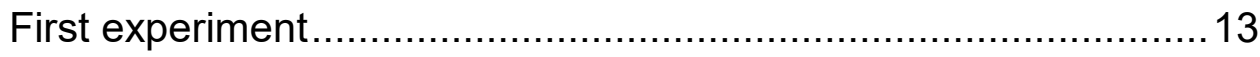

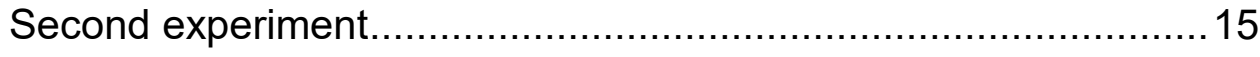

Post-experiment cathode

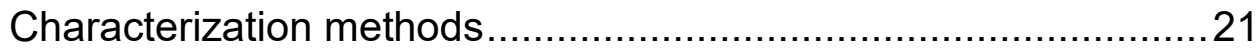

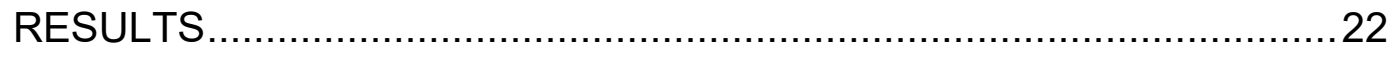

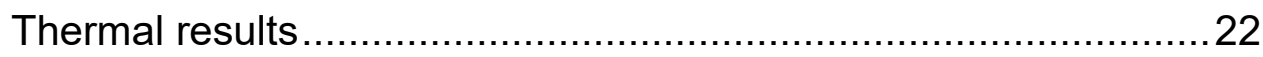

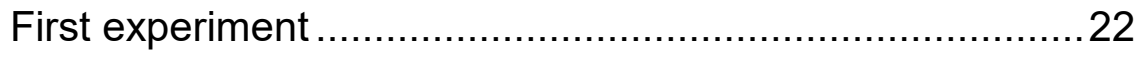

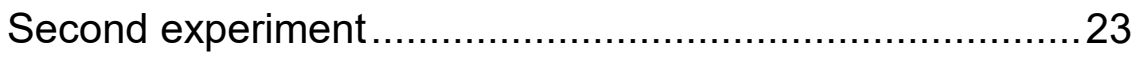


Cathode characterization results ............................................25

Blank piece of unelectrolyzed palladium ..........................25

Cathodes from first experiment....................................27

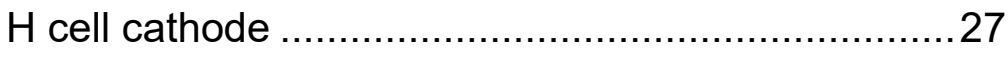

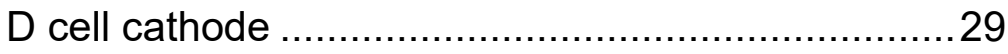

Cathodes from second experiment ................................. 30

$\mathrm{H}$ cell cathode ................................................ 30

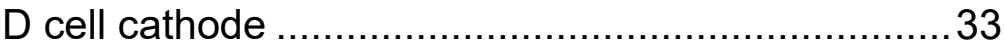

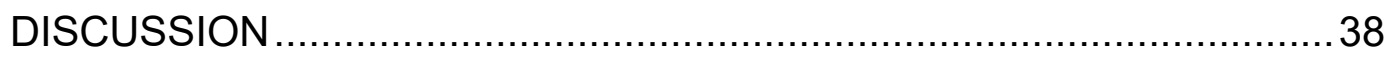

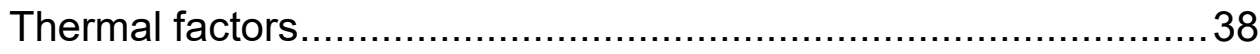

Thermodynamic considerations ...................................... 38

Heat results............................................................ 57

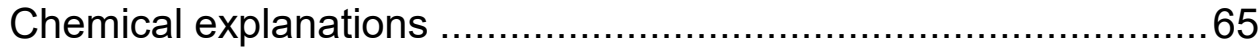

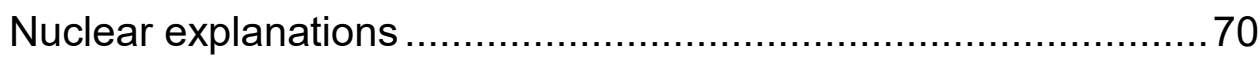

Related results that have been

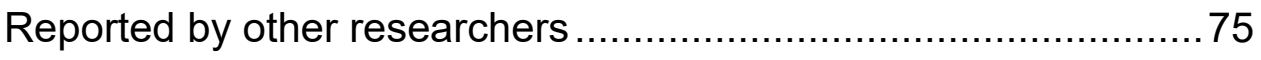

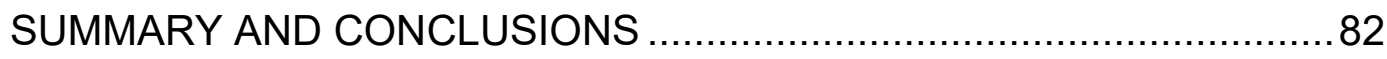


APPENDIX A: CALIBRATION OF THE TEMPERATURE SENSORS

IN THE SECOND EXPERIMENT

APPENDIX B: THERMAL EVOLUTION OF THE CELLS

IN THE FIRST EXPERIMENT

APPENDIX C: DETAILED FOLLOW-UP OF

SECOND EXPERIMENT

APPENDIX D: ADDITIONAL SPECTRA FROM

UNELECTROLYZED PALLADIUM

APPENDIX E: ADDITIONAL SPECTRA FROM THE

H CELL CATHODE

OF THE FIRST EXPERIMENT AFTER ELECTROLYSIS 138

APPENDIX F: ADDITIONAL SPECTRA FROM THE

D CELL CATHODE

OF THE FIRST EXPERIMENT AFTER ELECTROLYSIS 142 
APPENDIX G: ADDITIONAL MICROGRAPHS AND SPECTRA

FROM THE H CELL CATHODE OF THE

SECOND EXPERIMENT AFTER ELECTROLYSIS

APPENDIX H: ADDITIONAL MICROGRAPHS AND SPECTRA

FROM THE D CELL CATHODE OF THE

SECOND EXPERIMENT AFTER ELECTROLYSIS

APPENDIX I: SUPPLIERS

220 


\section{LIST OF TABLES}

Page

Table 1: Cell component description and mass

at the start of the first experiment

14

Table 2: Cell component description and mass

at the start of the second experiment

16

Table 3: Results of elemental analysis from

X-ray Spectrum of FIG. 6

26

Table 4: Analysis of X-ray spectrum of FIG. 6

for the metallic elements .................................................. 26

Table 5: Analysis of X-ray Spectrum of FIG. 7

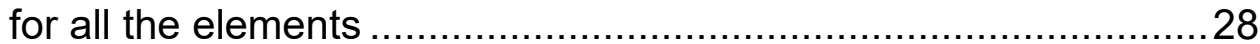

Table 6: Analysis of X-ray Spectrum of FIG. 7

for the metallic elements..................................................... 29

Table 7: Results of elemental analysis of spectrum of FIG. 11,

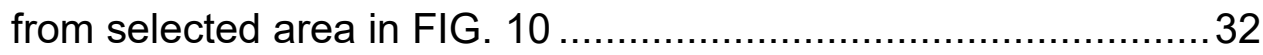


Table 8: Results of analysis of spectrum of FIG. 11, from selected area in FIG. 10, for the metallic elements 33

Table 9: Results of elemental analysis of spectrum of FIG. 16, from selected area in FIG. 15 37

Table 10: Results of analysis of spectrum of FIG. 16, from selected area in FIG. 15, (metallic elements) 37

Table 11: HEAT SUMMARY OF THE SECOND EXPERIMENT (FROM CELL MASS LOSSES) 62

Table 12: HEAT SUMMARY OF THE SECOND EXPERIMENT (FROM THE CURRENT) 64 


\section{LIST OF FIGURES}

FIG. 1: Appearance of $\mathrm{H}$ and $\mathrm{D}$ cells at the start of the second experiment

FIG. 2: Circuit diagram for the second experiment 18

FIG. 3: Photo of experimental setup for second experiment 19

FIG. 4: Comparison of power inputs in the run of January 18, 2002 24

FIG. 5: Comparison of cell temperatures in the run of January 18, 2002. 24

FIG. 6: Spectrum from selected area on unelectrolyzed Pd 25

FIG. 7: Spectrum from $2.1 \mathrm{~mm} \times 2.1 \mathrm{~mm}$ selected area on $\mathrm{H}$ cell cathode, of the first experiment 28

FIG. 8: H cell cathode before electrolysis, side of the spotweld (facing the anode) 30

FIG. 9: $\mathrm{H}$ cell cathode after electrolysis, side of the spotweld (facing the anode) 30 
FIG. 10: $0.11 \mathrm{~mm} \times 12 \mu \mathrm{m}$ fissure along edge of $\mathrm{H}$ cell cathode after electrolysis

FIG. 11: X-ray spectrum from selected area in FIG. 10 32

FIG. 12: D cell cathode of the second experiment before electrolysis, side opposite the spotweld (looking away from the anode) 34

FIG. 13: D cell cathode of the second experiment after electrolysis, side opposite the spotweld (looking away from the anode) 34

FIG. 14: Tip of D cell cathode of the second experiment after electrolysis (edge-on view) 35

FIG. 15: Tip of D cell cathode of the second experiment after electrolysis 36

FIG. 16: X-ray spectrum from selected area in FIG. 15 36

FIG. 17: Crystal unit cell of $\beta-P d H_{x}\left(\right.$ or $\left.\beta-P d D_{x}\right)$ 52

FIG. 18: Phase diagram of $\mathrm{PdH}_{\mathrm{x}}\left(\right.$ or $\left.P d D_{x}\right)$ at 1 atm .53 
Page

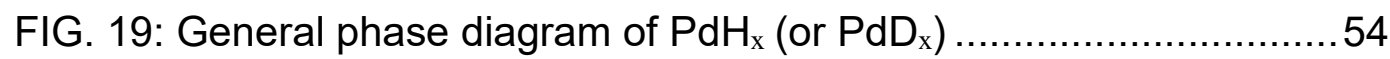




\section{INTRODUCTION:}

\section{Historical Overview:}

The field of solid state and plasma-discharge-induced nuclear reactions has made substantial advances over the past few years.

In March of 1989, Fleischmann and Pons announced that copious amounts of excess energy had been produced in their University of Utah lab by electrolyzing palladium in a $\mathrm{D}_{2} \mathrm{O}+\mathrm{LiOD}$ electrolyte. Their announced effect was not reproduced with success, and quickly fell in considerable disrepute (Peat, 1989; Rothman, 1990; Close, 1991; Taubes, 1993; Huizenga, 1994), which was aggravated by Fleischmann and Pons' claim that the excess energy in their electrochemical cells had been generated by $d-d$ nuclear fusion taking place in the palladium cathode (Fleischmann and Pons, 1989).

In the attempt to reproduce the Fleischmann and Pons effect, however, many scientists made remarkable new discoveries. In many cases, neutron bursts, anomalous energy production, helium-3, helium-4, gamma ray counts, charged particle emission and elemental transmutation have been reported (Storms, 1991; Beaudette, 2000).

The methods that have proved useful to produce excess energy include: 
-Electrolysis of $\mathrm{D}_{2} \mathrm{O}$-based electrolytes using a $\mathrm{Pd}$ cathode, performed between room temperature and $100{ }^{\circ} \mathrm{C}$ (Storms, 1991).

Hugo (1994) has reported over $12 \mathrm{~W} / \mathrm{cm}^{2}$ and a peak excess power of $23 \mathrm{~W}$ with a Pd cylinder charged equally from two sides.

Lewis and Sköld (1990), using fluid-flow and temperature change methods, have observed $1 \mathrm{~W} / \mathrm{cm}^{2}$ (total excess energy of $10^{5} \mathrm{~J}, 10^{5}$ $\mathrm{J} / \mathrm{cm}^{2}$ ), and power bursts up to $2 \mathrm{~W}$.

McKubre et al. (1994), employing sealed and pressurized cells, and working with several sample and calorimeter designs, have detected up to $10^{6} \mathrm{~J}$ excess energy and a peak excess power of $3 \mathrm{~W}$.

Gozzi et al. (1990, 1991), employing a dual calibration method and inert cathodes as blanks, have reported $1.8 \cdot 10^{6} \mathrm{~J}$ excess energy (over $1.7 \cdot 10^{6} \mathrm{~J} / \mathrm{cm}^{2}$ and $1.2 \mathrm{~W} / \mathrm{cm}^{2}$ ), with peak excess power of $12.8 \mathrm{~W}$.

Ota et al. (1994), with a $\mathrm{Pd}_{0.9} \mathrm{Ag}_{0.1}$ alloy, have reported $3.6 \cdot 10^{6} \mathrm{~J}$ of excess energy (over $2.3 \cdot 10^{6} \mathrm{~J} / \mathrm{cm}^{2}$ and $1.2 \mathrm{~W} / \mathrm{cm}^{2}$ ) and $7.2 \mathrm{~W} / \mathrm{cm}^{2}$ of excess power.

-Electrolysis of $\mathrm{H}_{2} \mathrm{O}$-based electrolyte employing a $\mathrm{Ni}$ cathode, performed between room temperature and $100{ }^{\circ} \mathrm{C}$ (Mills and Kneizys, 1991; Mills et 
al., 1992). Subsequent reports seem to corroborate the validity of this method (Mills et al., 1994).

The Patterson claim of energy generation in a specially designed cell containing small plastic nickel-coated beads and a $\mathrm{H}_{2} \mathrm{O}-\mathrm{Li}_{2} \mathrm{SO}_{4}$ electrolyte has been strongly contested, though the Patterson device has been demonstrated at several international conferences (Storms, 1991). Evidence of transmutation of potassium to calcium has been reported (Bush and Eagleton, 1993; Notoya and Enyo, 1993; Notoya, 1995). Indications of conversion of rubidium to strontium by the same process have also been noted (Bush and Eagleton, 1994).

Excess energy is also observed with $\mathrm{Cs}_{2} \mathrm{SO}_{4}$ in the electrolyte (Bush and Eagleton, 1994). Tritium (Ramamurthy et al., 1994; Notoya and Enyo, 1993) at low levels and other radioactive isotopes (Bush and Eagleton, 1994) have also been detected.

Unlike the $\mathrm{Pd}-\mathrm{D}_{2} \mathrm{O}$ system, which has a long and variable incubation period, the $\mathrm{Ni}-\mathrm{H}_{2} \mathrm{O}$ system seems to begin heat generation within one hour of the start of electrolysis. Alkali metal carbonates or hydroxides, as well as $\mathrm{Li}_{2} \mathrm{SO}_{4}$, seem to be successful in $\mathrm{Ni}-\mathrm{H}_{2} \mathrm{O}$ systems, whereas only LiOD and $\mathrm{Li}_{2} \mathrm{SO}_{4}$ seem to work in Pd-D $2 \mathrm{O}$ systems (Storms, 1991). 
-Electrolysis of $\mathrm{KCl}-\mathrm{LiCl}$ dissolved in $\mathrm{D}_{2} \mathrm{O}$ electrolytes with a Pd cathode at $450{ }^{\circ} \mathrm{C}$ (Liaw et al., 1990). Excess energy 15 times the applied electrolytic power has been reported. Helium was seemingly detected in the cathode, though not in amounts correlated with all the energy that was claimed.

-Acoustic implantation of deuterium into palladium bathed in $\mathrm{D}_{2} \mathrm{O}$ (Stringham and George, 1993). Significant excess energy (10-100 W) and helium generation (up to $550 \mathrm{ppm}$ ) are reported. The ${ }^{3} \mathrm{He} /{ }^{4} \mathrm{He}$ ratio is observed to rise $10^{3}$ times above background. Excess heat is not observed in $\mathrm{Pd}-\mathrm{H}_{2} \mathrm{O}$ or stainless steel- $\mathrm{D}_{2} \mathrm{O}$ combinations. No neutron or gamma emissions have been detected though investigation is ongoing.

-The passing of a small current $(40 \mu \mathrm{A})$ through a ceramic proton conductor like $\mathrm{Sr}(\mathrm{Ce}, \mathrm{Y}, \mathrm{Nb}) \mathrm{O}_{3}$ bathed in $\mathrm{D}_{2}$ gas and heated at $400-500{ }^{\circ} \mathrm{C}$ (Mizuno et al., 1994). Energy is generated during the deuterium absorption and desorption cycles as the polarity of the applied voltage $(18 \mathrm{~V})$ is reversed back and forth. No significant excess heat has been observed when $\mathrm{H}_{2}$ is used or when $\mathrm{Al}_{2} \mathrm{O}_{3}-\mathrm{SiO}_{2}$ is treated in the same way with $\mathrm{D}_{2}$. Nuclear byproducts have not been detected. Chemical explanations are limited since the ceramic is not reactive with hydrogen.

-Gas discharge of hydrogen with Pd electrodes (Dufour, 1994). The method of Dufour consists of bombarding Pd electrodes with ions generated in an 
ozoniser. The apparatus creates a discharge in the space between the two Pd electrodes, which is filled with $\mathrm{H}_{2}$ gas and which contains several Pyrex barriers. A mean excess energy of $2.1 \pm 0.5 \mathrm{~W}$ ( $66 \%$ of the input power) is reported.

- Gas discharge of deuterium with Pd electrodes (above $500{ }^{\circ} \mathrm{C}$ ) (Karabut $e t$ al., 1992). Karabut et al. report excess energy production (five times the input power) using a DC discharge $(100-500 \mathrm{~V}, 10-100 \mathrm{~mA})$ between a palladium cathode and a molybdenum anode. The ${ }^{90} \mathrm{Zr} /{ }^{91} \mathrm{Zr}$ ratio changed seemingly by a factor of 20 and the overall zirconium content rose from less than $0.05 \mathrm{ppm}$ to $1200 \mathrm{ppm}$. The changes seemed to be localized very near the bombarded surface.

-Placing of a specially treated nickel rod in hydrogen at $400{ }^{\circ} \mathrm{C}$ (Focard et al., 1994). No neutrons or gamma rays were initially reported above background, though subsequent studies revealed the presence of these emissions. Attempts to reproduce this work have failed as the details of the treatment have not been disclosed.

-Reaction of finely divided palladium (palladium-black) in a palladium tube with deuterium gas pressurized to 10 atmospheres (Arata and Zhang, 1994). A special treatment of the palladium-black seems to be required to rid it of 
surface impurities, and the effectiveness of this method is still being called into question.

\section{Previous experiments at PSU:}

Before the Fleischmann and Pons announcement, Cousins at Portland State University (1982) had investigated the application of magnetic fields to electrolyzing systems with water and $\mathrm{H}_{2} \mathrm{SO}_{4}$ in the electrolyte, observing some thermal gradient in the direction of the Lorentz force.

When the Fleischmann and Pons announcement was made in 1989, there was at the Portland State University Physics department a sudden stimulus to look at the possibility of obtaining excess energy and perhaps nuclear byproducts from electrolytic cells. Since there was no LiOD available at the time at Portland State University, $\mathrm{H}_{2} \mathrm{SO}_{4}$-water cells similar to those that had been employed earlier by Cousins would be used.

Keefe (1990) was then assigned to conduct two experiments to look for signs of nuclear reactions in $\mathrm{Pd} / \mathrm{H}_{2} \mathrm{SO}_{4}+$ water/Pt cells.

For Keefe's first experiment, Donald Howard of the Physics department at Portland State University lent some palladium. It was only a small amount, and so to 
fabricate the cathodes it was cold-rolled to only $0.03 \mathrm{~mm}$ thickness. The thus constructed cathode sheets measured $5 \mathrm{~mm} \times 3 \mathrm{~cm}$. One cathode was placed in the light water cell $\left(\mathrm{H}_{2} \mathrm{O}+\mathrm{H}_{2} \mathrm{SO}_{4}\right)$, and the other in the heavy water cell $\left(\mathrm{D}_{2} \mathrm{O}+\mathrm{H}_{2} \mathrm{SO}_{4}\right)$. Platinum wire was spotwelded to the back side of each cathode. The anodes were prepared from cold-rolled platinum sheets $0.03 \mathrm{~mm}$ and $2 \mathrm{~cm}$ square, with another Pt wire spotwelded to the sheets. Both cells were placed in series. Indications of excess heat from the heavy water cell relative to the light water cell did arrive towards the end of this first electrolysis experiment by Keefe, which went on for over 45 hours, and was mostly conducted under a constant current of $0.75 \mathrm{~A}$. The cathode sheets bent around too much, however, due to their thinness, and so for Keefe's second experiment new palladium would be purchased which would be cold-rolled only to $\sim 0.3 \mathrm{~mm}$ thickness.

For his second experiment, Keefe's palladium was then cold-rolled from its lot's original thickness of $0.5 \mathrm{~mm}$ to $0.35 \mathrm{~mm}$ prior to being cut into $2.5 \mathrm{~mm} \times 4 \mathrm{~cm}$ cathodes. Both of his cells employed again platinum foil anodes. Platinum wires were spotwelded to both cathodes and anodes. About $1 \mathrm{~cm}^{2}$ of the Pd cathodes were kept submerged in the electrolyte. The light water cell again had $\mathrm{H}_{2} \mathrm{O}+\mathrm{H}_{2} \mathrm{SO}_{4}$ in the electrolyte and the heavy water cell again had $\mathrm{H}_{2} \mathrm{O}+\mathrm{H}_{2} \mathrm{SO}_{4}$. Both cells were identical in every other respect and were again placed in series to receive equal current, something which would become standardized practice at the Portland State University physics lab. The applied constant current was 0.5 A for the first 48 hours of electrolysis and $0.75 \mathrm{~A}$ for the remaining 120 hours. 
Increased tritium decays were measured in the heavy water electrolyte of Keefe's first experiment after electrolysis, but in Keefe's second experiment the tritium counts in the after-electrolysis heavy water electrolyte were basically the same as in the before-electrolysis heavy water electrolyte, and no definitive conclusions could be drawn. Checks for gamma radiation were also inconclusive.

Elizabeth Newlon Nicholas (1992) prolonged Keefe's second experiment for many more hours, finding that the excess heat of the heavy water cell relative to the light water cell was maintained and even increased.

Noble (1994) found later gold on $\sim 50 \mu \mathrm{m}$-sized plateaus that had appeared on both of Keefe's second experiment cathodes after Nicholas finished the extra runs. The plateaus had risen on the lower tips of the cathodes on the sides that had been facing the anodes.

The decision was adopted to continue at Portland State University research on this type of $\mathrm{Pd} / \mathrm{D}_{2} \mathrm{O}+\mathrm{H}_{2} \mathrm{SO}_{4} / \mathrm{Pt}$ versus $\mathrm{Pd} / \mathrm{H}_{2} \mathrm{O}+\mathrm{H}_{2} \mathrm{SO}_{4} / \mathrm{Pt}$ electrolytic systems, using for the cathodes Pd slightly cold-rolled from the manufacturer's lot. In addition to their promise as manifested in Keefe's, Nicholas' and Noble's work, the choice of an acidic electrolyte offered over the traditional, basic, LiOD-based electrolytes the advantage that the electrolyte did not leach the glass.

Subsequent work at Portland State University has indicated that a mixed acidic solution of $\mathrm{H}_{2} \mathrm{O}$ and $\mathrm{D}_{2} \mathrm{O}$ might even work better than $\mathrm{D}_{2} \mathrm{O}$ alone. This is also hinted in recent experiments by Mizuno et al. (2001), which have detected 
significant neutron bursts after performing electrolysis of Pd cathodes in heavy water and then transferring the cathodes to light water cells. The neutron bursts took place with the Pd cathodes already in light water, either immediately after electrolysis was commenced in this new medium or when the voltage was raised. In the heavy water preliminary phase of electrolysis, $0.2 \mathrm{M}$ of $\mathrm{K}_{2} \mathrm{CO}_{3}$ was dissolved. Both in the light and in the heavy water phases, the anode was a platinum mesh that surrounded the cathode. The Pd cathode was a wire $1 \mathrm{~mm}$ in diameter and $3 \mathrm{~cm}$ in length. The light water cell was made of Pyrex glass, with a diameter of $10 \mathrm{~cm}$ and a height of $20 \mathrm{~cm}$, and had a silicon rubber lid. In the light water phase the voltage was $40 \mathrm{~V}$ and the current reached a maximum of $8 \mathrm{~A}$. Neutron bursts were detected in 7 out of 10 experiments.

Parallel work at Portland State University has also employed titanium cathodes in $\mathrm{D}_{2} \mathrm{O}+\mathrm{H}_{2} \mathrm{SO}_{4} / \mathrm{H}_{2} \mathrm{O}+\mathrm{H}_{2} \mathrm{SO}_{4}$ type cells, with successful, if not always fully reproducible, results (Warner, 1998, 2001). Excess heat was initially observed in the $0.1-0.2 \mathrm{~W}$ range, at levels that were significant but not above $3 \sigma$ (Warner, 1998).

In his first experiment, Warner's control cell started with 18 grams of $\mathrm{H}_{2} \mathrm{O}$ and 1 gram of $\mathrm{H}_{2} \mathrm{SO}_{4}$. His experimental cell started with 14.3 grams of $\mathrm{D}_{2} \mathrm{O}$ and 1 gram of $\mathrm{H}_{2} \mathrm{SO}_{4}$. His titanium cathodes measured $1 \mathrm{~mm} \times 0.13 \mathrm{~mm} \times 1 \mathrm{~cm}$. The anodes were made of platinum. Both cells received a constant current of 0.20 A. The average excess heat for the 30 valid minutes of steady-state in that first experiment 
was $0.13 \pm 0.08 \mathrm{~W}$. In his second experiment, the experimental cell started with 14.3 grams of $\mathrm{D}_{2} \mathrm{O}$ and 1 gram of $\mathrm{H}_{2} \mathrm{SO}$; his control cell started with 17.6 grams of $\mathrm{H}_{2} \mathrm{O}$ and 1 gram of $\mathrm{H}_{2} \mathrm{SO}_{4}$. The current through both cells was initially held at $0.20 \mathrm{~A}$, then raised to $0.30 \mathrm{~A}$, to $0.40 \mathrm{~A}$, and finally lowered to $0.25 \mathrm{~A}$. In this second experiment, the experimental cell employed a titanium cathode $(2 \mathrm{~mm} \times 0.13 \mathrm{~mm} \times$ $1.06 \mathrm{~cm})$ while the control cell used a platinum cathode $(1.5 \mathrm{~mm} \times 0.04 \mathrm{~mm} \times 1$ $\mathrm{cm})$. The anodes were also of Pt. No excess heat was found and in fact the indication was that the platinum cathodes had been generating more heat than the titanium cathodes. After these two experiments, Energy Dispersive Spectrometry (EDS) found no new elements on the cathodes that could not be attributable to contamination. Subsequent experiments with pairs of $\mathrm{Ti} / \mathrm{D}_{2} \mathrm{O}+\mathrm{H}_{2} \mathrm{SO}_{4} / \mathrm{Pt}$ cells that differed only slightly in the width of the cathodes and a reference control $\mathrm{Ti} / \mathrm{H}_{2} \mathrm{O}+\mathrm{H}_{2} \mathrm{SO}_{4} / \mathrm{Pt}$ cell all showed excess heat in the $0.1-0.2 \mathrm{~W}$ range, in two cases above $3 \sigma$. Subsequent EDS analysis clearly indicated that new elements $(\mathrm{K}, \mathrm{Ca}, \mathrm{V}$, $\mathrm{Cr}, \mathrm{Fe}, \mathrm{Ni}$ ) could have been produced on the titanium cathodes during the electrolysis, as background checks and repeated analysis after ultrasonically rinsing the cathodes eliminated the possibility that the presence of these elements was due to contamination.

In subsequent and much more extensive work, Warner (2001) found excess heat above $0.1 \mathrm{~W}$ and $5 \sigma$ in over one third of 64 experimental Ti/ $\mathrm{D}_{2} \mathrm{O}+\mathrm{H}_{2} \mathrm{SO}_{4} / \mathrm{Pt}$ cells. Half of the excess-heat-producing cathodes revealed evidence of Cr upon EDS after electrolysis, and over one third of the non-excess heat producing cells displayed 
signs of $\mathrm{Cr}$ and other elements. Secondary Ion Mass Spectrometry also confirmed the presence of chromium. As much as $30 \% \mathrm{TiH}$ was found on the surface of the cathode up to a depth of $1 \AA$, and the Transmission Electron Microscope (TEM) pointed to the presence of $\beta-\mathrm{TiO}_{2}$. Warner found that a $20 \%$ reduction of the titanium thickness from that given by the manufacturer yielded optimum heat results.

Further work at PSU continued finding possible evidence for transmutation on Pd and Ti cathodes in aqueous electrolytic systems (Dash et al., 1997; Silver and Dash, 1999).

Recent developments by other researchers in the field (Bernardini et al., 2000) have also accentuated the viability of titanium electrolytic systems as producers of excess heat. A release of over $10^{5} \mathrm{~J}$ was detected from an unknown source $(\sim 1 \mathrm{~W}$ average) after electrolysis of $0.6 \mathrm{M} \mathrm{K}_{2} \mathrm{CO}_{3}$ in $\mathrm{D}_{2} \mathrm{O}$. Gamma spectroscopy also appeared to detect emissions from the Ti samples after the end of electrolysis, emissions that could not be attributed to radioactive impurities.

Li et al. (2000) have reported the appearance of nickel on a $2 \mu \mathrm{m}$ x $50 \mu \mathrm{m}$ x 100 cm Pd wire on a glass substrate upon deuterium absorption in electrolysis. DougarJabon et al. (2000) have found neutron emissions in the accumulative recrystallization phase of deuterium-loaded palladium above $500{ }^{\circ} \mathrm{C}$. Miley et al. (2000) have described finding energy outputs of 100-200 W/cm ${ }^{3}$, far in excess of any chemical source, as well as isotopic reaction byproducts, from arrays of layered 
Pd-Ni thin films (five alternating $\sim 1000 \AA$ layers ending with Pd on the outer surface), in $\mathrm{Li}_{2} \mathrm{SO}_{4}-\mathrm{H}_{2} \mathrm{O}$ or $\mathrm{Li}_{2} \mathrm{SO}_{4}-\mathrm{D}_{2} \mathrm{O}$ solutions. That corresponded to an unprecedented $\sim 10-20 \mathrm{~W}$ per gram of metal $(\mathrm{Pd}, \mathrm{Ni})$, in contrast with the power densities of $\sim 0.1-0.4 \mathrm{~W}$ reported by Miles (1995) with solid Pd electrodes, or the $\sim 0.006 \mathrm{~W} / \mathrm{g}$ of McKubre (1999). A 5 second duration $1 \mathrm{~kW}$ power burst was reported.

\section{The present project:}

In the light of all these developments, the decision was adopted to carry out two new experiments at Portland State University. The specific aims of these two new experiments were:

-To look again at the excess heat that a cell with a palladium cathode, a platinum anode, and a solution of sulfuric acid in heavy water $\left(\mathrm{D}_{2} \mathrm{O}\right)$ can produce under electrolysis, relative to an identical cell with light water $\left(\mathrm{H}_{2} \mathrm{O}\right)$ as the solvent.

-To evaluate the changes in morphology and composition that electrolysis brought.

The cathodes would be cut into strips of the same dimensions as in Keefe's second experiment ( $\sim 0.3 \mathrm{~mm} \times 3 \mathrm{~mm} \times 4 \mathrm{~cm}$ with $\sim 1 \mathrm{~cm}^{2}$ exposed to the electrolyte). The 
anodes would be $0.1 \mathrm{~mm} \times 12 \mathrm{~mm} \times 25 \mathrm{~mm}$ Pt sheets (in Keefe's second experiment, the heavy water cell anode had been a folded-up $0.03 \mathrm{~mm} \times 20 \mathrm{~mm} \times$ $120 \mathrm{~mm}$ sheet while the light water cell anode had been a $0.03 \mathrm{~mm} \times 20 \mathrm{~mm} \times 20$

mm sheet). Analysis with the Scanning Electron Microscope (SEM) and Energy Dispersive Spectrometry (EDS) would be performed on the cathodes following the two experiments to study the microchemical changes produced by the electrolysis.

\section{MATERIALS AND METHODS:}

\section{First experiment:}

In both experiments the heavy water cell (D cell) used $\mathrm{D}_{2} \mathrm{O}$ from Aldrich, Lot \#04344PS, 99.96\%. The light water cell (H cell) used deionized $10 \mathrm{M} \Omega \mathrm{cm} \mathrm{H}_{2} \mathrm{O}$. The palladium cathodes in both cells were from Alfa Aesar, Stock \#11514, Lot \#E06J04, 99.9\%. The platinum anodes were from Alfa Aesar, PREMION, Stock $\# 11509$, Lot \#J18K06, 99.99\%. The platinum of the electrode lead wires was from Aldrich, Lot number KI02916LU 175 mg/cm, 99.99\%. 
In the first experiment the lead wires had a diameter of $1 \mathrm{~mm}$ in the $\mathrm{H}$ cell and of $0.5 \mathrm{~mm}$ in the D cell. Previous work had indicated that cold-rolling increased the likelihood of producing excess heat (Noble et al., 1995; Warner, 2001), so the palladium of the cathodes was cold-rolled $30 \%$ prior to the experiment, and then subjected to two cleaning cycles (each one consisting of $5^{\prime}$ in a bath of deionized water in ultrasonics), followed by a rinse in methanol. The cathodes and anodes were spotwelded to their respective lead wires, and after the spotweld they were cleaned with sulfuric acid followed by another two standard cleaning cycles and a rinse in methanol. The spotweld area of the cathodes was then sheathed in a Teflon tube and was shrunken by heating to seal the interface with the cathode.

The components of both cells for the first experiment are listed in Table 1:

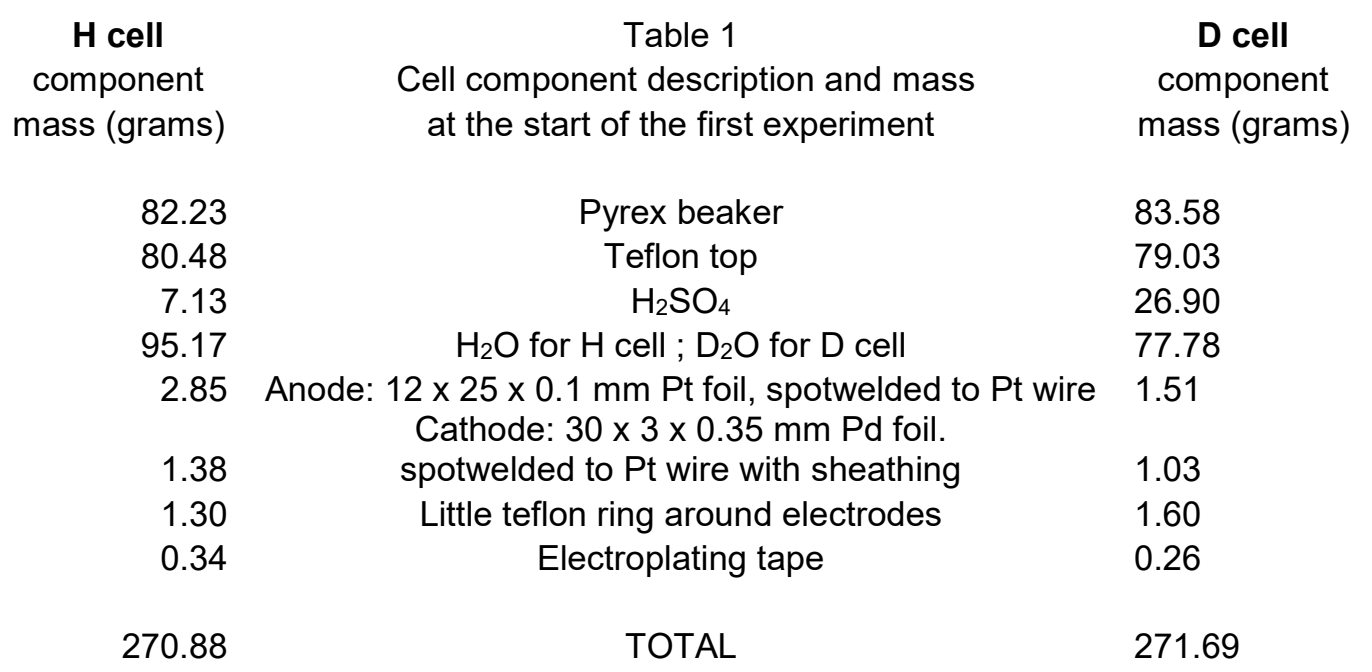


If one of the two cells had to be slightly heavier, the proper choice was the D cell. If the D cell had a slightly higher thermal inertia a possible excess heat reading in the D cell compared to the $\mathrm{H}$ cell would be strengthened.

The two cells were placed in series and supplied the same current of $0.75 \mathrm{~A}$. In this first experiment, the software that was usually employed to monitor the cell temperatures through thermocouples was not available. To have an approximate idea of the thermal evolution of the cells, two thermocouples were attached to each cell at the same positions and were connected to a strip chart recorder. The voltage difference across the thermocouple was translated manually to ${ }^{\circ} \mathrm{C}$.

\section{Second experiment:}

In the second experiment the lead wires for the electrodes were of $1 \mathrm{~mm}$ diameter except for the lead wire of the cathode of the $\mathrm{H}$ cell, which was made from two pieces that were spotwelded together. The lower piece of the wire had a length of $63 \mathrm{~mm}$ and a diameter of $0.8 \mathrm{~mm}$. The upper piece had a length of $53 \mathrm{~mm}$ and a diameter of $1 \mathrm{~mm}$.

The palladium of the cathodes was cold-rolled $46 \%$ from its initial dimensions of $25 \times 4.16 \times 0.5$ millimeters to $33 \times 5.5 \times 0.27$ millimeters. The cathodes and anodes were spotwelded to their respective lead wires, and after the spotweld they were cleaned with sulfuric acid followed by another two standard cleaning cycles and a 
rinse in methanol. The spotweld area of the cathodes was then sheathed in a Teflon ring and was shrunken by heating to seal the interface with the cathode. The unsheathed surface of the cathode was $21 \mathrm{~mm} \times 5.5 \mathrm{~mm}$ and was fully submerged in the electrolyte at the start of this second experiment.

The components of both cells for the second experiment are summarized in Table

2:

\begin{tabular}{|c|c|c|}
\hline $\begin{array}{c}\text { H cell } \\
\text { component } \\
\text { mass (grams) }\end{array}$ & $\begin{array}{l}\text { Table } 2 \\
\text { Cell component description and mass } \\
\text { at the start of the second experiment }\end{array}$ & $\begin{array}{c}\text { D cell } \\
\text { component } \\
\text { mass (grams }\end{array}$ \\
\hline 82.33 & Pyrex beaker & 80.64 \\
\hline 80.47 & Teflon top & 79.03 \\
\hline 2.34 & $\mathrm{H}_{2} \mathrm{SO}_{4}$ & 13.95 to 15.78 \\
\hline 53.30 & $\mathrm{H}_{2} \mathrm{O}$ for $\mathrm{H}$ cell $; \mathrm{D}_{2} \mathrm{O}$ for $\mathrm{D}$ cell & 48.13 to 46.29 \\
\hline 2.48 & $\begin{array}{c}\text { Anode: } 12 \times 25 \times 0.1 \mathrm{~mm} \text { Pt foil, spotwelded to Pt wire } \\
\text { Cathode: } 21 \times 5.5 \times 0.27 \mathrm{~mm} \mathrm{Pd} \mathrm{foil}\end{array}$ & 3.03 \\
\hline 2.40 & spotwelded to Pt wire with sheathing & 3.20 \\
\hline 0.73 & Little teflon tube around electrodes & 0.62 \\
\hline 0.76 & Electroplating tape on teflon top & 0.85 \\
\hline 2.62 & Electroplating tape to secure teflon top to beaker & 1.11 \\
\hline 227.42 & TOTAL & 230.56 \\
\hline
\end{tabular}

A drawing showing to scale the components of the cells and the electrolyte level at the start of the second experiment is shown in FIG. 1. 
FIG. 1: Appearance of $H$ and $D$ cells at the start of the second experiment

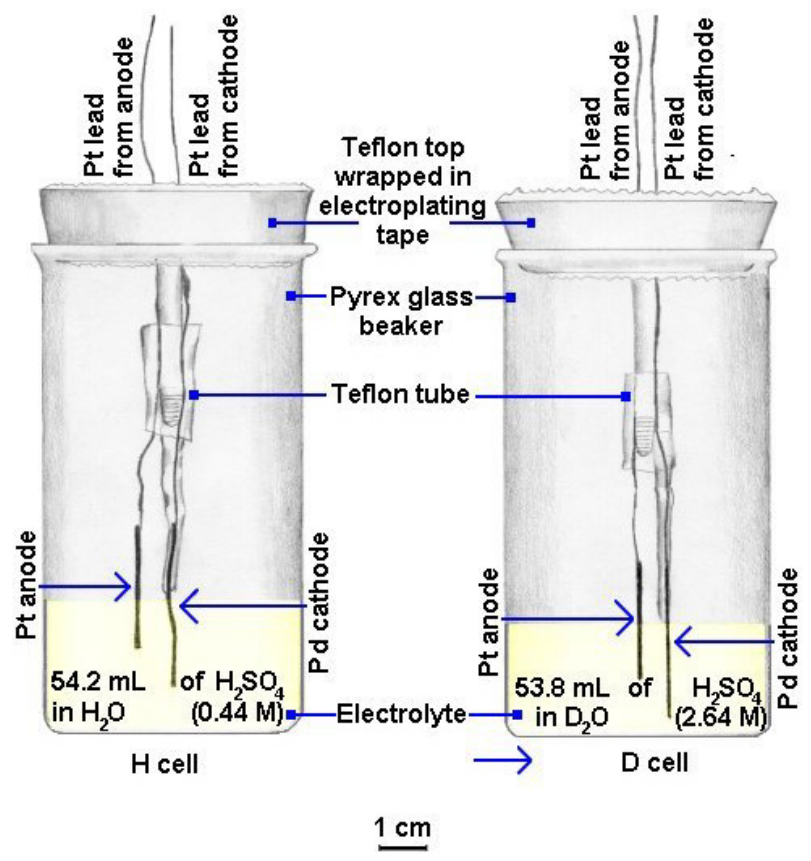

The box in which the Pyrex glass beakers had been shipped, which had holes already cut out in the cardboard with the diameter of the beakers and measured 32 $\mathrm{cm} \times 5 \mathrm{~cm} \times 25 \mathrm{~cm}$, was used to hold the cells in place during this second experiment. The two cells were placed in the same row in the two farthest removed holes. About $18 \mathrm{~cm}$ of air separated the two cells. The box with the cells was placed on the lab countertop with two weights placed inside in the middle to prevent the box from being moved or tipped over accidentally. A 31 centimeter long mercury thermometer was laid horizontally on the box right between the two cells so its bulb would be in the midpoint between the cells.

There was a double-pole, double-throw current switch in the circuit to measure the cell voltages by means of a Keithley digital multimeter (177 Microvolt). Hence one 
could monitor with the multimeter the voltage across either the $\mathrm{H}$ or $\mathrm{D}$ cell by turning the switch. Constant current was supplied by a Hewlett-Packard HARRISON 6202B DC power source, and the two cells were connected in series. The negative terminal of the power supply was wired to the cathode of the $\mathrm{H}$ cell; the anode of the $\mathrm{H}$ cell was wired to the cathode of the $\mathrm{D}$ cell; the anode of the D cell was wired to the negative terminal of a D.C. ammeter; and the positive terminal of the ammeter was wired back to the positive terminal of the power supply. The multimeter was placed approximately 32 centimeters from the box with the cells.

The full circuit diagram is shown in FIG. 2.

FIG. 2: Circuit diagram for the second experiment.

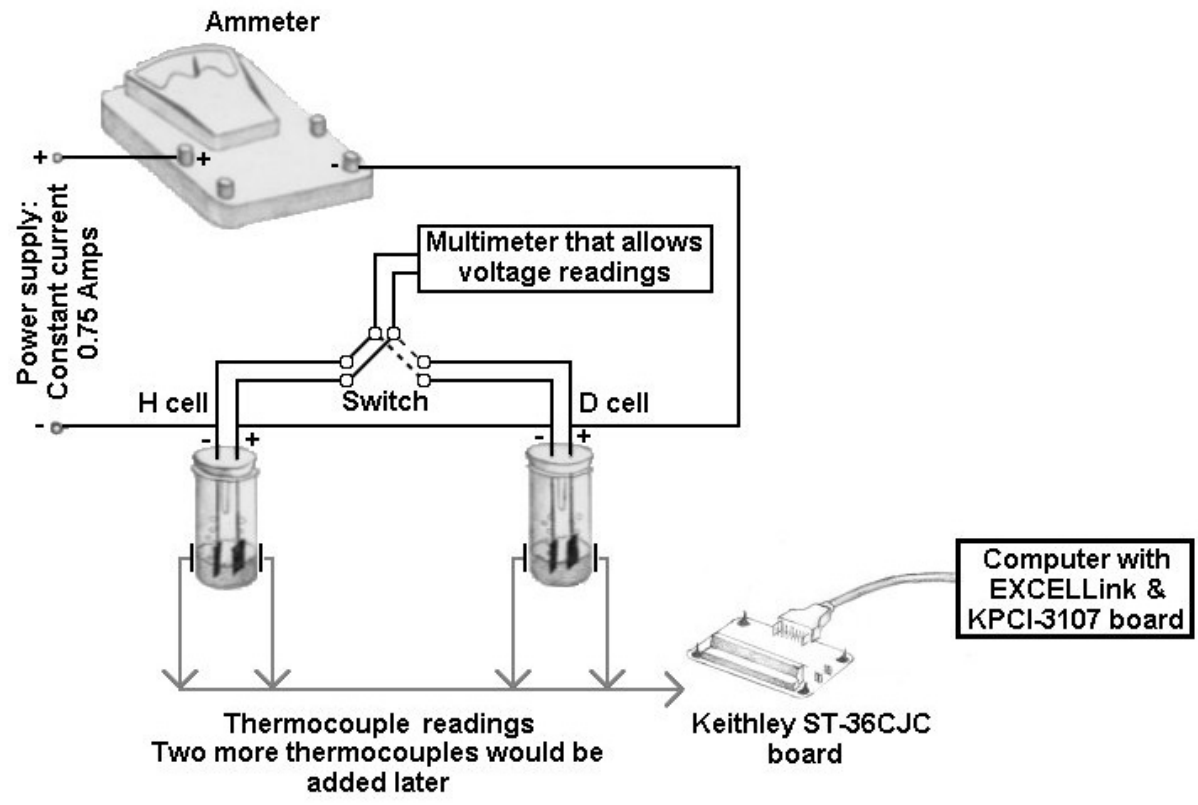


Temperatures were recorded with 3 foot long Type SA1-K OMEGA precision fine wire thermocouples, which had a diameter of $0.25 \mathrm{~mm}$, were insulated in Teflon, and were flattened at the hot junctions to achieve good contact with the cell walls. The adhesive contacts containing the hot junctions had dimensions of $25 \mathrm{~mm} \times 19$ $\mathrm{mm}$. The thermocouples had lost their adhesive quality due to previous usage and so in this experiment were affixed to the glass cells using thin transparent tape. The thermocouples were connected to a KPCI-3107/STP-36CJC Keithley data acquisition board (serial number 0875032, STP-36CJC), which was first used in its differential mode. In this differential mode, one leg of the thermocouple is hooked up in each channel to the positive terminal and the other leg is hooked up to the negative terminal. FIG. 3 shows the full experimental setup.

FIG. 3: Photo of experimental setup for second experiment

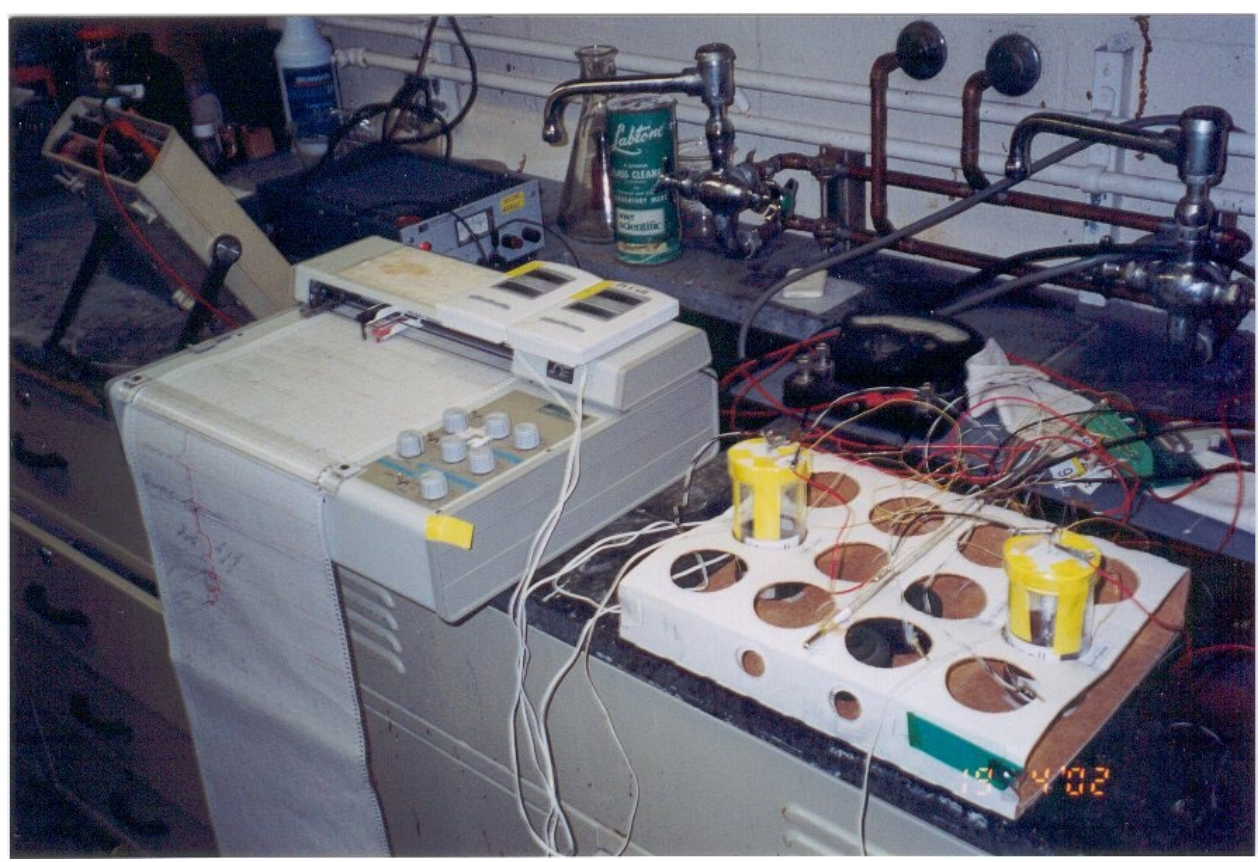


The KPCI-3107/STP-36CJC board came equipped with ExceLINX software, courtesy of Keithley instruments. This new software translated automatically thermocouple readings to temperatures and recorded them in Excel. The resulting temperature recordings from each thermocouple would subsequently be calibrated with the mercury thermometer that had been placed between the cells. Two thermocouples were attached to each cell in the same position at the start of this second experiment, to monitor the temperatures on the sides of the cell walls in the electrolyte-covered portion. Two more thermocouples would be added in each cell for the last runs of the second experiment, one to monitor the temperature at the bottom and one to monitor the temperature at the top.

Additionally, two Radio-Shack LCD Dual Display Indoor/Outdoor thermometers were affixed with tape to the bottom of the cells in the same position relative to the electrodes for an independent visual reading of the temperature. The calibration of all these thermocouples and of the LCD dual display thermometers would be conducted after the end of this second experiment.

For details about this calibration, please refer to Appendix A.

Current was set at $0.75 \mathrm{~A}$ for all the runs of this second experiment using the constant current procedure given in the manual of the power supply. This corresponded to an approximate cathode current density of $0.65 \mathrm{~A} / \mathrm{cm}^{2}$ at the start of the experiment when the full unsheathed area of the cathodes was submerged. 


\section{Post-experiment}

\section{Cathode characterization methods:}

At the end of both experiments, the cathodes from both experiments were examined visually and characterized using a Scanning Electron Microscope (SEM) and Energy Dispersive Spectrometry (EDS).

The SEM was an ISI-SS40 model. It was equipped with an OXFORD EDS detector. The detector model was 5565. The detector area was $10 \mathrm{~mm}^{2}$. Its resolution was $138 \mathrm{eV}$. The detector was coupled with ISIS software (the name of the specific program was SEMQuant) that estimated the elemental composition of a spot or reduced area on the sample based on the X-ray spectrum. The more X-ray counts that were acquired, the more accurate that the X-ray analysis turned out to be. The accelerating voltage was set at $20 \mathrm{kV}$ for all characterizations.

The SEM characterization was done with great care to minimize any possible contamination of the cathodes that would be examined. Pincers washed in methanol were used to place and remove the cathodes from the brass stage in the SEM vacuum chamber. The cathodes were affixed to the stage with an aluminum stub. The stage itself was handled with gloves. After each analysis, the cathode was returned to its vial. 
Before the cathodes from the cells of both experiments were characterized, the preliminary step was to examine a piece of unelectrolyzed palladium from the same lot from which the cathodes had been cut and cold-rolled. This blank piece of unelectrolyzed palladium was therefore cold-rolled in the same way as the cathodes, then put through two standard cleaning cycles and finally rinsed in methanol following the same cleaning procedure that had been used for the cathodes prior to assembling the cells.

\section{RESULTS:}

\section{Thermal results:}

\section{First experiment:}

Although thermocouple readings were not available for the first experiment, the indications from the strip chart recorder were that for the most of 60 hours of electrolysis that were conducted the $\mathrm{H}$ (light water) cell was slightly warmer $\left(\sim 1^{\circ}\right.$ C) than the $\mathrm{D}$ (heavy water) cell, with the $\mathrm{H}$ cell was receiving slightly less $(\sim 5 \%)$ power. 
For more details about the thermal evolution of the cells in this first experiment, please refer to Appendix B.

\section{Second experiment:}

In the second experiment, a total of 8119 minutes of electrolysis were conducted for both cells. Of these, 7250 minutes were of steady-state. In the first run, however, which lasted for 261 minutes and had 216 minutes of steady-state, the D cell was run with the polarity reversed by mistake. As a result, some palladium was dissolved, and a deposit of powdery black substance formed around the cathode of this cell. During the course of electrolysis, it was observed that the cathode of the D cell bent towards the anode, while the cathode of the $\mathrm{H}$ cell remained straight.

The $\mathrm{H}$ cell was always kept at a higher voltage than the $\mathrm{D}$ cell; for the majority of the runs this potential difference was about $0.2-0.3$ Volts. In spite of this, the D cell remained warmer for most of the minutes of electrolysis.

There was a run, performed on January 18,2002 , in which the D cell temperature surpassed the $\mathrm{H}$ cell temperature by more than $2{ }^{\circ} \mathrm{C}$. In this run, the $\mathrm{H}$ cell was at an average of 3.74 Volts during the 671 minutes of steady-state, while the D cell was at an average of 3.47 Volts (FIG. 4). The $\mathrm{H}$ cell responded by being at an average temperature of $32.9 \pm 0.4{ }^{\circ} \mathrm{C}$ (measured by two thermocouples), with the $\mathrm{D}$ cell at 
$34.8 \pm 0.4{ }^{\circ} \mathrm{C}$ (FIG. 5). For more details about the thermal evolution of the cells in this second experiment, please refer to Appendix C.

FIG. 4: Comparison of power inputs in the run of January 18, 2002.

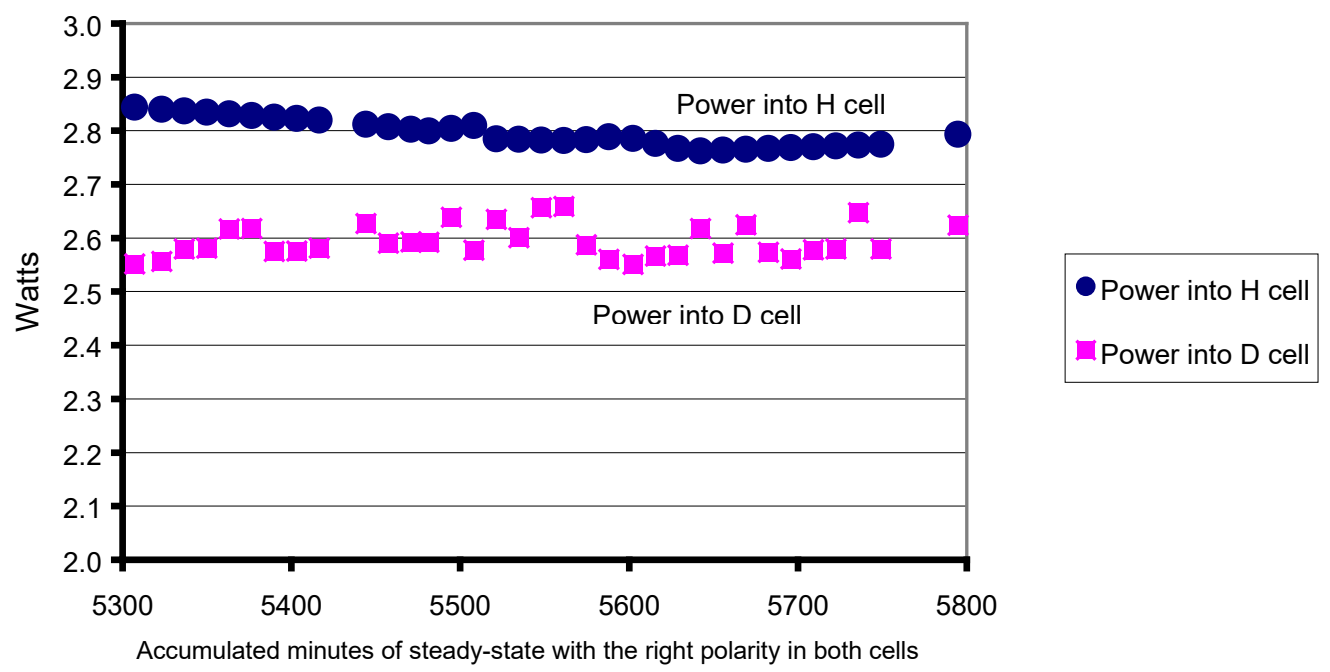

FIG. 5: Comparison of cell temperatures in the run of January 18, 2002.

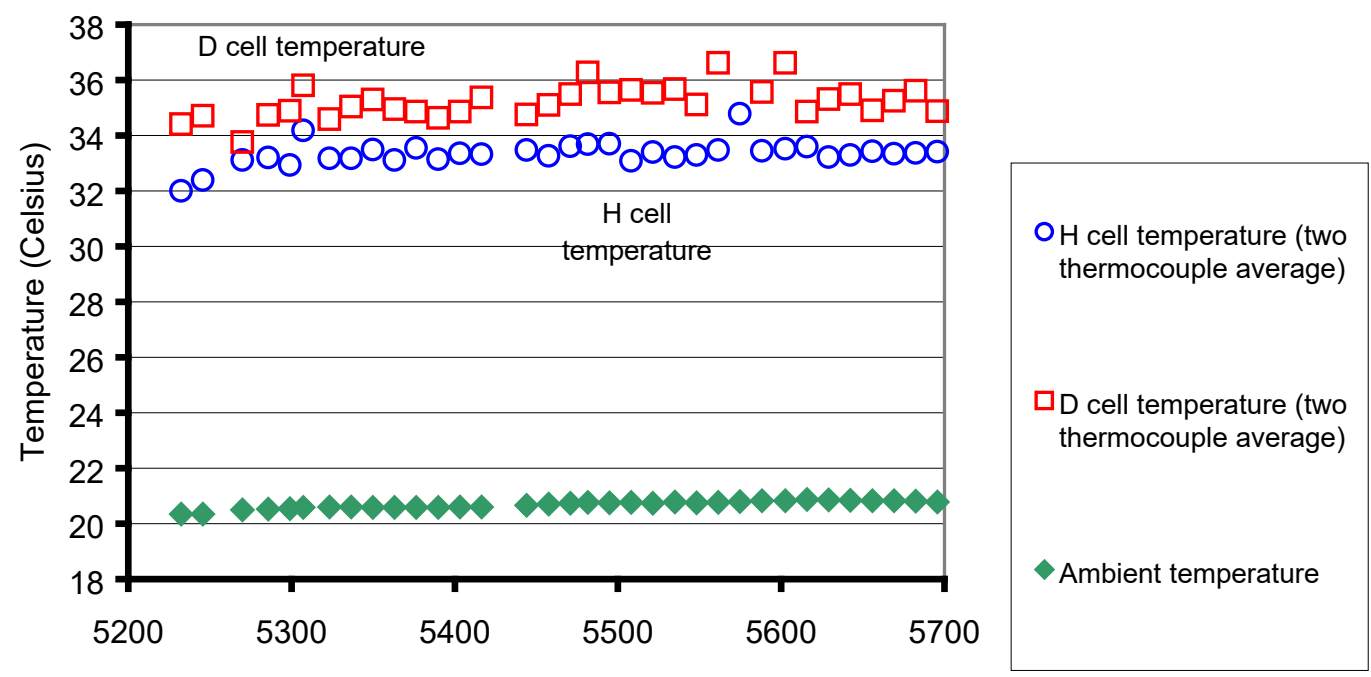

Accumulated minutes of steady-state with the right polarity in both cells 


\section{Cathode characterization results:}

Blank piece of unelectrolyzed palladium:

The piece of unelectrolyzed cold-rolled palladium that had been chosen as a blank was examined with EDS. It had only Pd. No traces of $\mathrm{Ag}$ or $\mathrm{Cd}$ were found.

A representative spectrum is shown in FIG. 6. It was acquired from a $2.5 \mathrm{~mm} \times 2.5$ $\mathrm{mm}$ square selected area. The results of the SEMQuant analysis on this spectrum for all the elements are listed in Table 3. Table 4 lists the results for the metallic elements only:

FIG. 6: Spectrum from selected area on unelectrolyzed Pd.

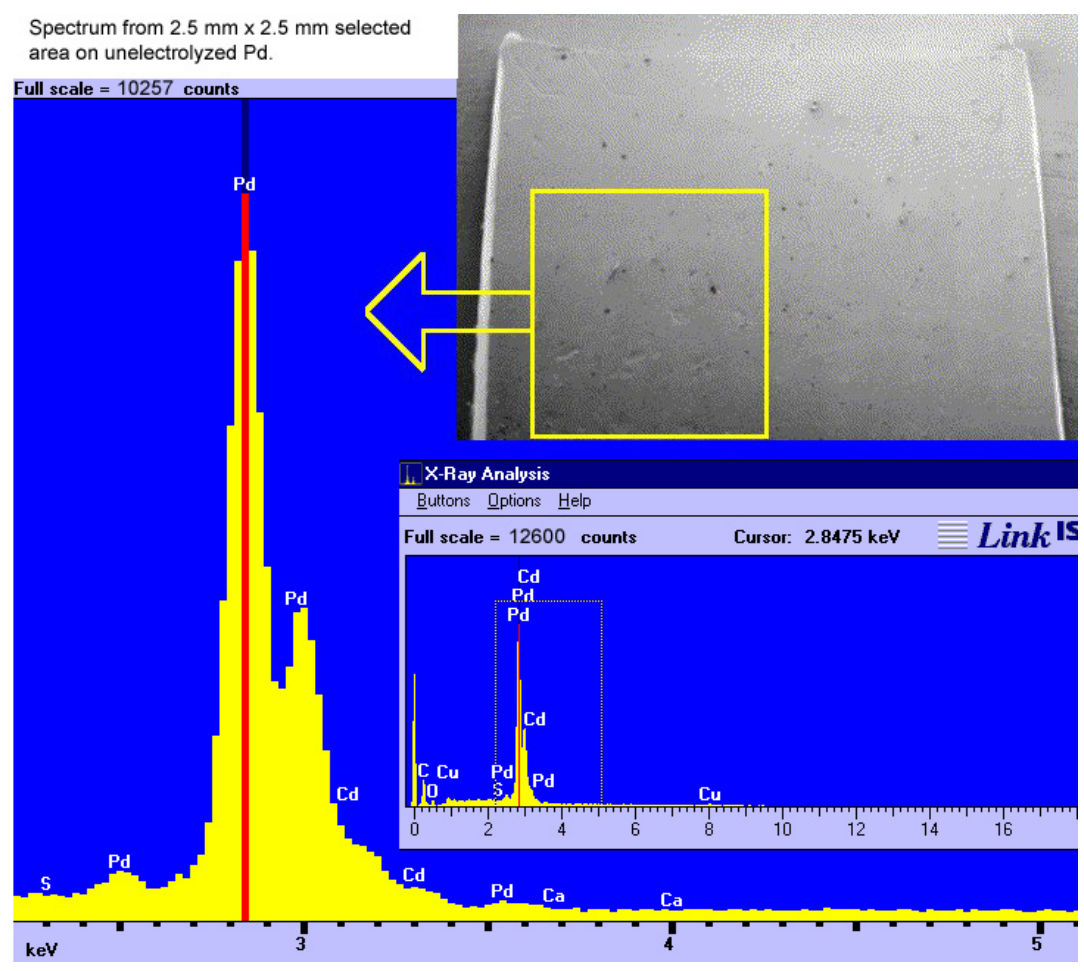


Table 3: Results of elemental analysis from X-ray Spectrum of FIG. 6.

\begin{tabular}{lrrr}
\multicolumn{5}{c}{$\begin{array}{c}\text { In number } \\
\text { of atoms }\end{array}$} & In mass & \multicolumn{2}{l}{ 位 mass } \\
C & $41.93 \%$ & $10.56 \%$ & $0.20 \%$ \\
$\mathrm{O}$ & $20.69 \%$ & $6.94 \%$ & $0.48 \%$ \\
$\mathrm{~S}$ & $0.07 \%$ & $0.04 \%$ & $0.06 \%$ \\
$\mathrm{Cu}$ & $1.09 \%$ & $1.45 \%$ & $0.24 \%$ \\
$\mathrm{Pd}$ & $36.09 \%$ & $80.51 \%$ & $0.85 \%$ \\
$\mathrm{Ag}$ & $0.00 \%$ & $0.00 \%$ & $0.70 \%$ \\
$\mathrm{Cd}$ & $0.00 \%$ & $0.00 \%$ & $0.42 \%$ \\
$\mathrm{Pt}$ & $0.13 \%$ & $0.51 \%$ & $0.20 \%$
\end{tabular}

(Surface analysis up to a depth of $\sim 1 \mu \mathrm{m}$ ).

Table 4: Analysis of X-ray spectrum of FIG. 6 for the metallic elements. An actual separate analysis was conducted for these elements.

\begin{tabular}{|c|c|c|c|}
\hline & $\begin{array}{l}\text { In number } \\
\text { of atoms }\end{array}$ & In mass & $\sigma_{\text {in mass }}$ \\
\hline $\mathrm{Cu}$ & $2.87 \%$ & $1.72 \%$ & $\quad 9.51 \%$ \\
\hline$P d$ & $96.81 \%$ & $97.67 \%$ & $35.74 \%$ \\
\hline $\mathrm{Ag}$ & $0.00 \%$ & $0.00 \%$ & $29.18 \%$ \\
\hline $\mathrm{Cd}$ & $0.00 \%$ & $0.00 \%$ & $17.38 \%$ \\
\hline $\mathrm{Pt}$ & $0.32 \%$ & $0.60 \%$ & $8.20 \%$ \\
\hline
\end{tabular}

(Surface analysis up to a depth of $\sim 1 \mu \mathrm{m}$ ).

For more details about this spectrum and other spectra that were taken from this blank piece of unelectrolyzed palladium, please refer to Appendix D. 
Cathodes from first experiment:

\section{$H$ cell cathode:}

Silver was present on the $\mathrm{H}$ cell cathode of the first experiment, which finished the runs slightly bent.

$5.05 \pm 0.34 \% \mathrm{Ag}$ in number of atoms was found on a large $(2.1 \mathrm{~mm} \times 2.1 \mathrm{~mm})$ area on the concave side of the $\mathrm{H}$ cell cathode of this first experiment, very near its tip. On that region, the number concentration of $\mathrm{Pd}$ was $68.73 \pm 0.37 \%$.

FIG. 7 shows the X-ray spectrum from this region. Table 5 displays the results for all the elements; Table 6 displays the results for the metallic elements only. 
FIG. 7: Spectrum from $2.1 \mathrm{~mm} \times 2.1 \mathrm{~mm}$ selected area on $\mathrm{H}$ cell cathode of the first experiment

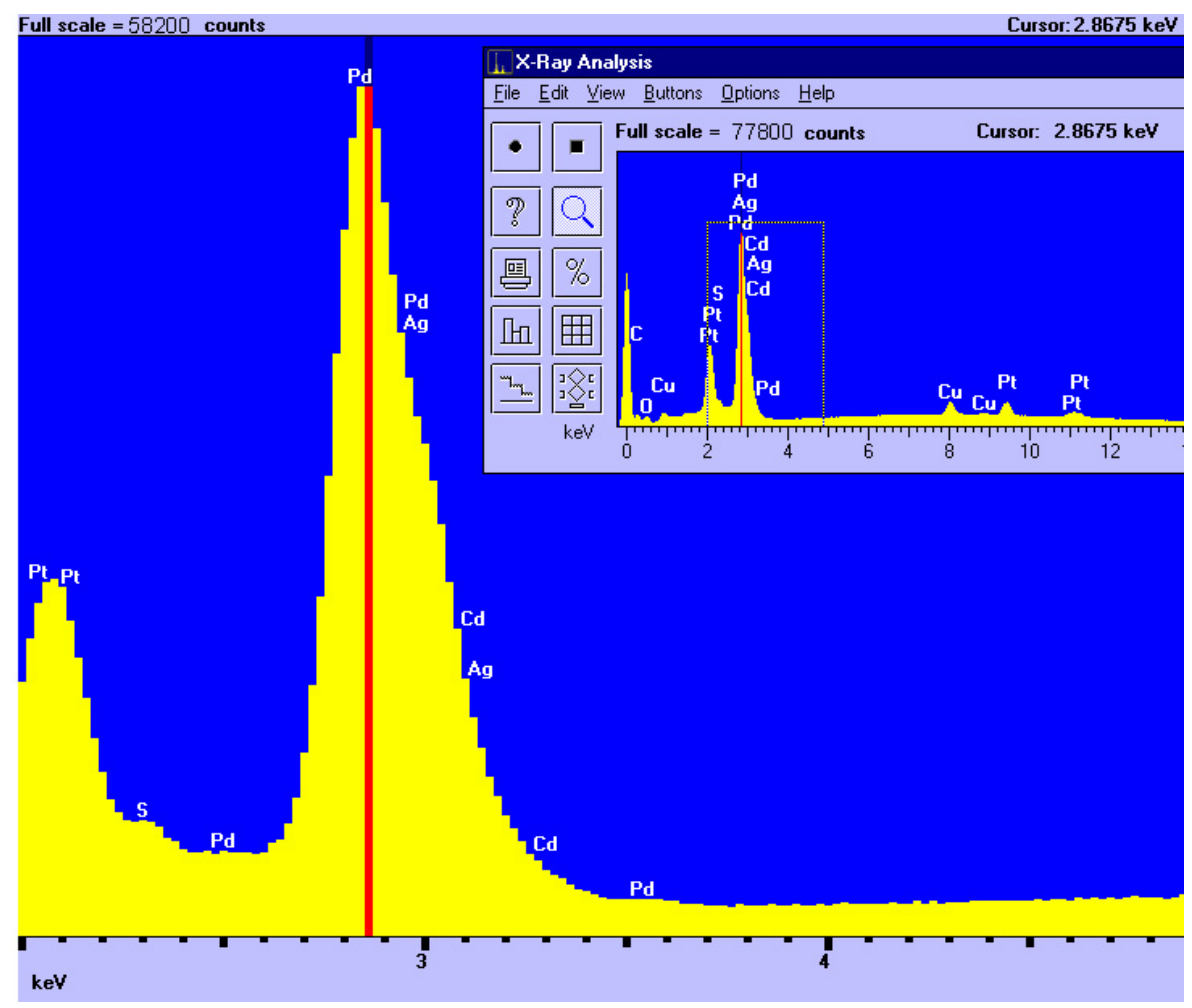

Table 5: Analysis of X-ray Spectrum of FIG. 7 for all the elements.

\begin{tabular}{lrrr}
\multicolumn{5}{c}{ In number } & & \\
& of atoms & In mass & \multicolumn{1}{l}{ 位 mass } \\
$\mathrm{C}$ & $0.00 \%$ & $0.00 \%$ & $0.11 \%$ \\
$\mathrm{O}$ & $31.06 \%$ & $6.24 \%$ & $0.18 \%$ \\
$\mathrm{~S}$ & $3.24 \%$ & $1.31 \%$ & $0.05 \%$ \\
$\mathrm{Cu}$ & $9.03 \%$ & $7.20 \%$ & $0.17 \%$ \\
$\mathrm{Pd}$ & $44.87 \%$ & $59.95 \%$ & $0.35 \%$ \\
$\mathrm{Ag}$ & $3.22 \%$ & $4.35 \%$ & $0.31 \%$ \\
$\mathrm{Cd}$ & $0.11 \%$ & $0.16 \%$ & $0.25 \%$ \\
$\mathrm{Pt}$ & $8.48 \%$ & $20.78 \%$ & $0.17 \%$
\end{tabular}

(Surface analysis up to a depth of $\sim 1 \mu \mathrm{m}$. Some of the $\mathrm{Cu}$ reading might have been a systems peak from the brass stage.) 
Table 6: Analysis of X-ray Spectrum of FIG. 7 for the metallic elements.

\begin{tabular}{lrrr}
\multicolumn{5}{c}{ In number } & & \\
& of atoms & In mass & \multicolumn{1}{c}{$\sigma_{\text {in mass }}$} \\
$\mathrm{Cu}$ & $13.84 \%$ & $7.90 \%$ & $0.18 \%$ \\
$\mathrm{Pd}$ & $68.73 \%$ & $65.68 \%$ & $0.35 \%$ \\
$\mathrm{Ag}$ & $5.05 \%$ & $4.90 \%$ & $0.33 \%$ \\
$\mathrm{Cd}$ & $0.25 \%$ & $0.26 \%$ & $0.27 \%$ \\
$\mathrm{Pt}$ & $12.13 \%$ & $21.26 \%$ & $0.18 \%$
\end{tabular}

(Surface analysis up to a depth of $\sim 1 \mu \mathrm{m}$. Some of the $\mathrm{Cu}$ reading might have been a systems peak from the brass stage.)

On the opposite side of this $\mathrm{H}$ cell cathode, the concentration of Ag was lower but still statistically significant. For more details, please refer to Appendix E.

\section{D cell cathode:}

On the D cell cathode of this first experiment, which finished the runs somewhat less bent than the $\mathrm{H}$ cell cathode, $\mathrm{Ag}$ number abundances of $7 \%$ (above $3 \sigma$ ) relative to Pd were found over large millimeter-sized areas.

On the convex side of the D cell cathode, there was over 1 atom of $\mathrm{Ag}$ for 5 of Pd on a $13 \mu \mathrm{m} \times 13 \mu \mathrm{m}$ area.

For details about the spectra that were taken, please refer to Appendix F. 
Cathodes from second experiment:

\section{H cell cathode:}

FIG. 8 shows the appearance of the $\mathrm{H}$ cell cathode before the experiment, while FIG. 9 shows the appearance after the electrolysis.

FIG. 8: $\mathrm{H}$ cell cathode before electrolysis, side of the spotweld (facing the anode).

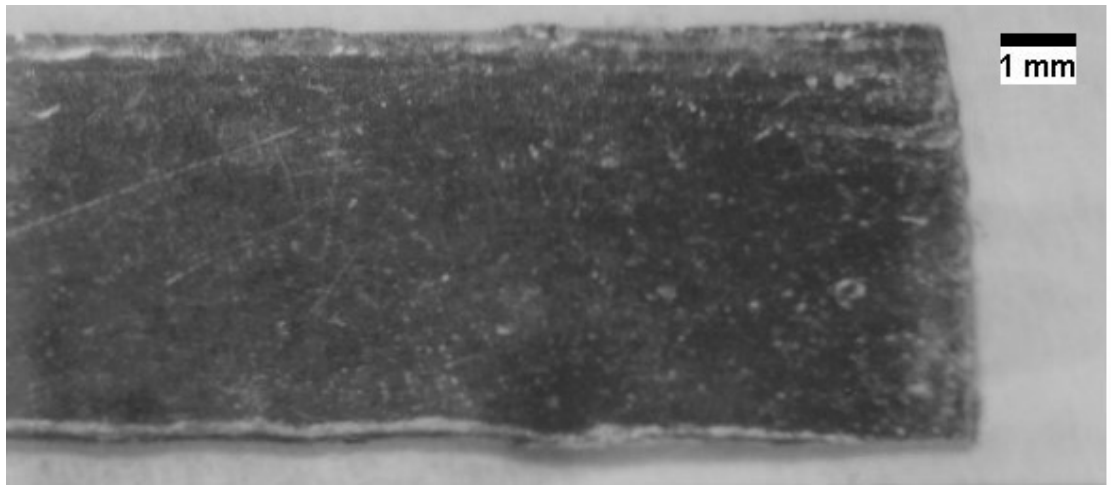

FIG. 9: H cell cathode after electrolysis, side of the spotweld (facing the anode).

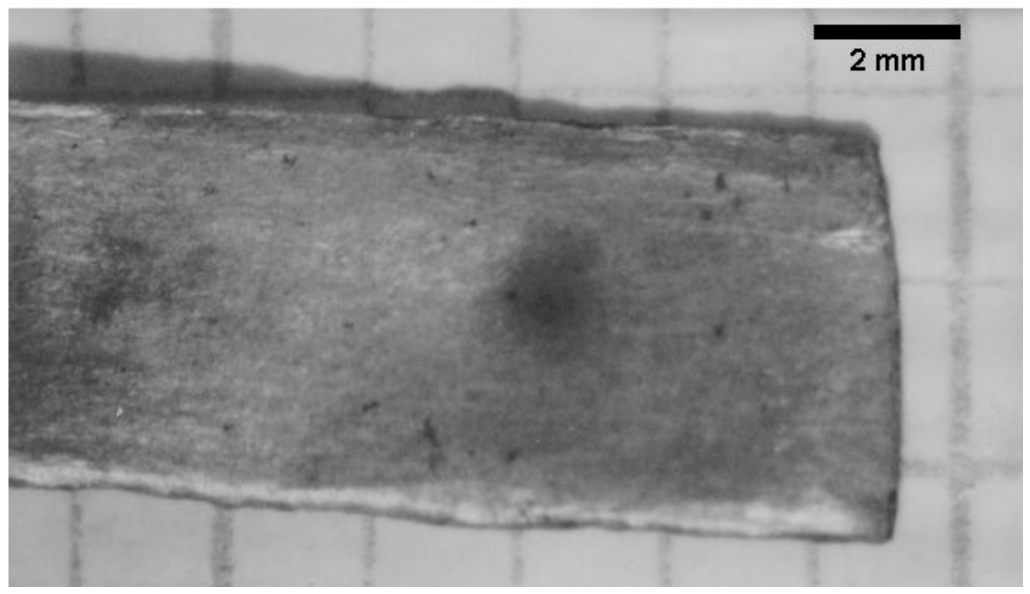


Cadmium was present over both sides of the $\mathrm{H}$ cell cathode after electrolysis, at levels of $5 \%$ relative to Pd in number of atoms, though it was not clear from the spectra that were taken if this Cd was uniformly spread out over large areas or localized in small pockets. The Cd SEMQuant readings were above $3 \sigma$. Inside crevices, the concentration of $\mathrm{Cd}$ was higher. $\mathrm{Ag}$ was also found, mostly in localized cavities.

In a $0.11 \mathrm{~mm} \times 12 \mu \mathrm{m}$ fissure along edge of the cathode, there were over 7 atoms of Cd for every 10 of Pd. FIG. 10 shows the area and FIG. 11 shows the X-ray spectrum. Table 7 lists the results of the SEMQuant analysis for all the elements, while Table 8 lists the results for the metallic elements only.

FIG. 10: $0.11 \mathrm{~mm} \times 12 \mu \mathrm{m}$ fissure along edge of $\mathrm{H}$ cell cathode after electrolysis. This was the side opposite the spotweld, looking away from the anode. The lower tip of the cathode lies $2.3 \mathrm{~mm}$ above this picture (with the scale of $20 \mu \mathrm{m}$ indicated by the marker).

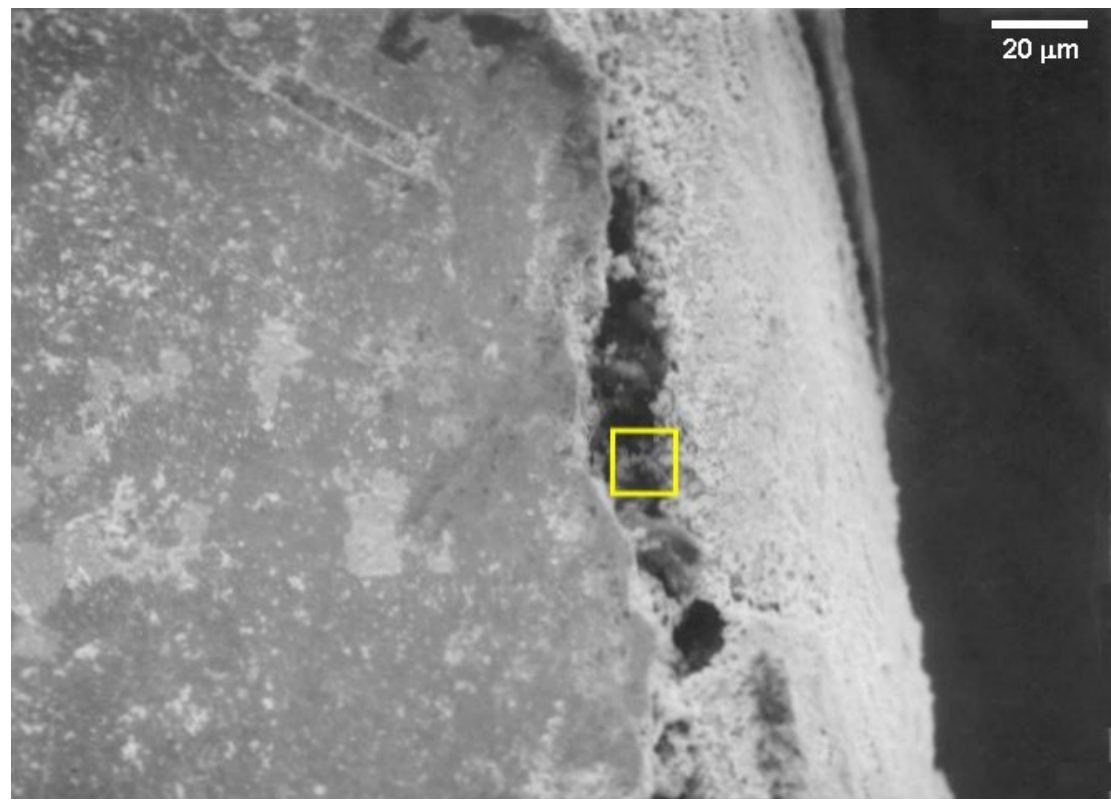


FIG. 11: X-ray spectrum from selected area in FIG. 10

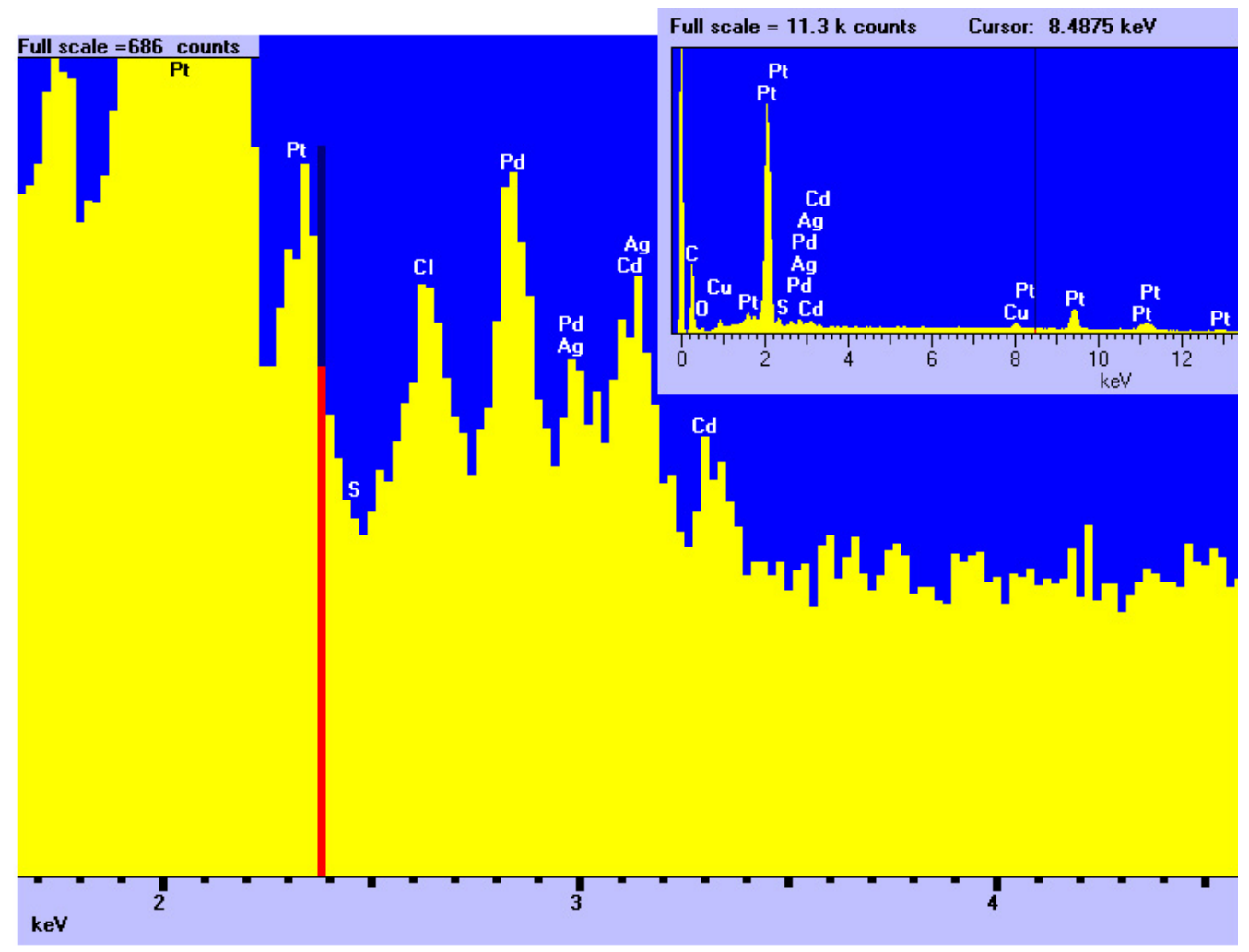

Table 7: Results of elemental analysis of spectrum of FIG. 11, from selected area in FIG. 10.

\begin{tabular}{lrrr}
\multicolumn{5}{c}{$\begin{array}{l}\text { In number } \\
\text { of atoms }\end{array}$} & In mass & \multicolumn{2}{l}{$\sigma_{\text {in }}$ mass } \\
C & $85.46 \%$ & $35.34 \%$ & $0.34 \%$ \\
$\mathrm{O}$ & $3.62 \%$ & $1.99 \%$ & $0.25 \%$ \\
$\mathrm{~S}$ & $0.00 \%$ & $0.00 \%$ & $0.09 \%$ \\
$\mathrm{Cu}$ & $1.59 \%$ & $3.48 \%$ & $0.25 \%$ \\
$\mathrm{Pd}$ & $0.65 \%$ & $2.37 \%$ & $0.27 \%$ \\
$\mathrm{Ag}$ & $0.04 \%$ & $0.16 \%$ & $0.29 \%$ \\
$\mathrm{Cd}$ & $0.49 \%$ & $1.91 \%$ & $0.24 \%$ \\
$\mathrm{Pt}$ & $8.15 \%$ & $54.70 \%$ & $0.42 \%$
\end{tabular}

(Surface analysis up to a depth of $\sim 1 \mu \mathrm{m}$ ). 
Table 8: Results of analysis of spectrum of FIG. 11, from selected area in FIG. 10, for the metallic elements. An actual separate SEMQuant analysis was conducted for these elements only.

\begin{tabular}{|c|c|c|c|}
\hline & $\begin{array}{l}\text { In number } \\
\text { of atoms }\end{array}$ & In mass & $\sigma_{\text {in }}$ mass \\
\hline $\mathrm{Cu}$ & $13.48 \%$ & $5.12 \%$ & $0.36 \%$ \\
\hline $\mathrm{Pd}$ & $6.37 \%$ & $4.05 \%$ & $0.45 \%$ \\
\hline $\mathrm{Ag}$ & $0.42 \%$ & $0.27 \%$ & $0.49 \%$ \\
\hline $\mathrm{Cd}$ & $4.82 \%$ & $3.24 \%$ & $0.41 \%$ \\
\hline $\mathrm{Pt}$ & $74.90 \%$ & $87.32 \%$ & $0.77 \%$ \\
\hline
\end{tabular}

(Surface analysis up to a depth of $\sim 1 \mu \mathrm{m}$. Some of the $\mathrm{Cu}$ reading might have been a systems peak from the brass stage).

For more micrographs and spectra from the $\mathrm{H}$ cell cathode following electrolysis, please refer to Appendix G.

\section{D cell cathode:}

In the second experiment, the $\mathrm{D}$ cell cathode finished markedly bent (by $\sim 30^{\circ}$ ). FIG. 12 shows the D cell cathode before electrolysis and FIG. 13 shows the D cell cathode after electrolysis. 
FIG. 12: D cell cathode of the second experiment before electrolysis, side opposite the spotweld (looking away from the anode).

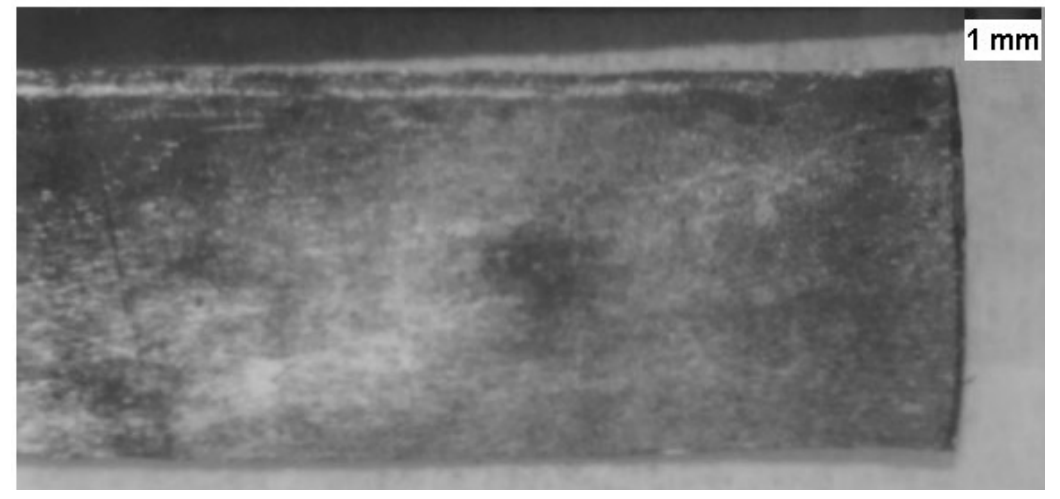

FIG. 13: D cell cathode of the second experiment after electrolysis, side opposite the spotweld (looking away from the anode).

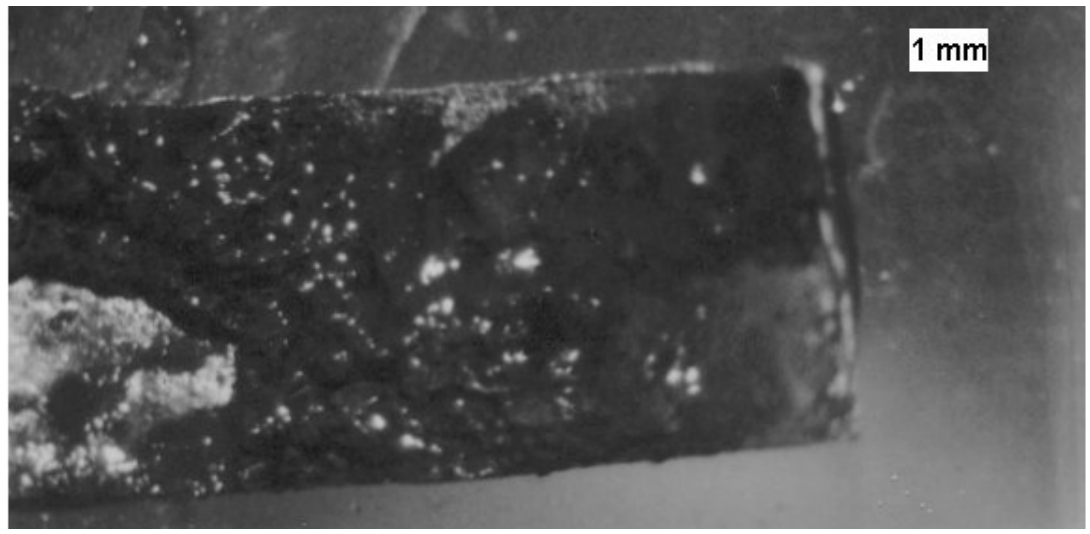

FIG. 14 shows a close-up edge-on view of the tip of the D cell cathode after electrolysis. 
FIG. 14: Tip of D cell cathode of the second experiment after electrolysis.

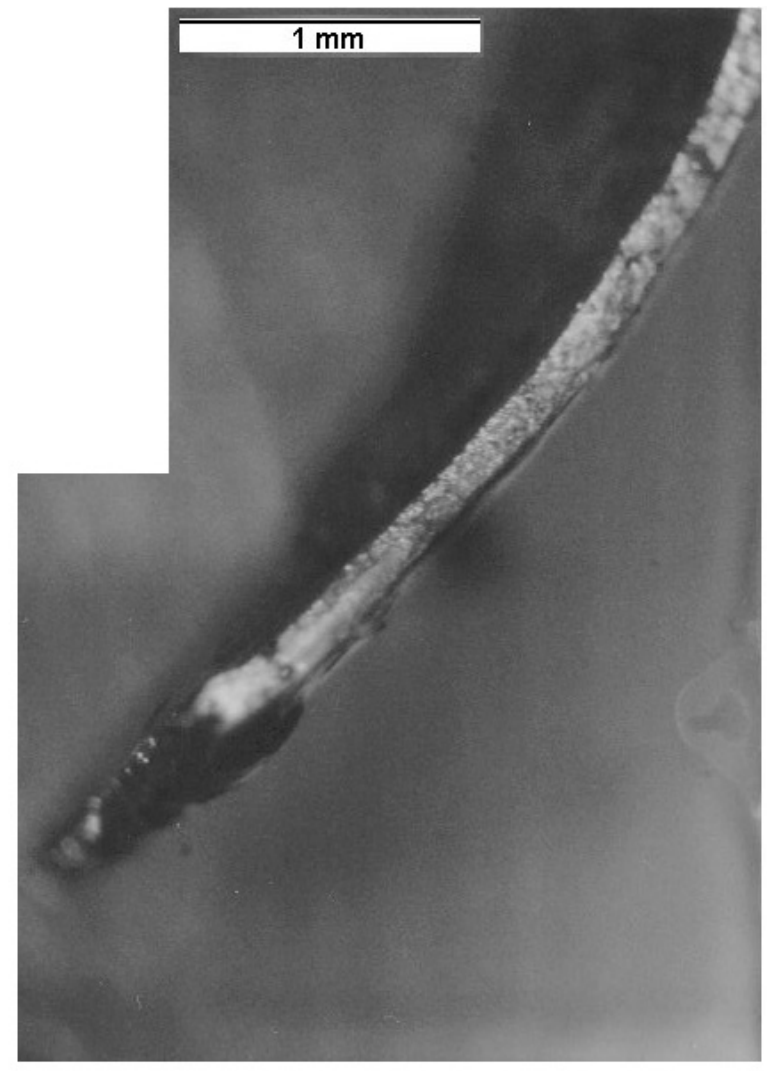

Traces of Cd could have been present in the X-ray spectra from some areas on the D cell cathode after electrolysis, but the main finding was silver, whose number abundance relative to $\mathrm{Pd}$ reached $20 \%$ on some localized spots.

X-rays were acquired from a $2.5 \mathrm{~mm}$ x $2.5 \mathrm{~mm}$ selected area on the convex spotweld side of the D cathode very close to the lower tip. This convex side was facing the anode when the experiment was finished. FIG. 15 shows the region, which was covered in the deposit of black substance, and the selected area. FIG. 16 shows the spectrum from this selected area. Table 9 lists the results of the SEMQuant analysis for all the elements; while Table 10 lists the results for the 
metallic elements only. The number abundance of $\mathrm{Ag}$ over that area was $4.31 \pm 0.34 \%$ relative to $\mathrm{Pd}$.

FIG. 15: Tip of D cell cathode of the second experiment after electrolysis

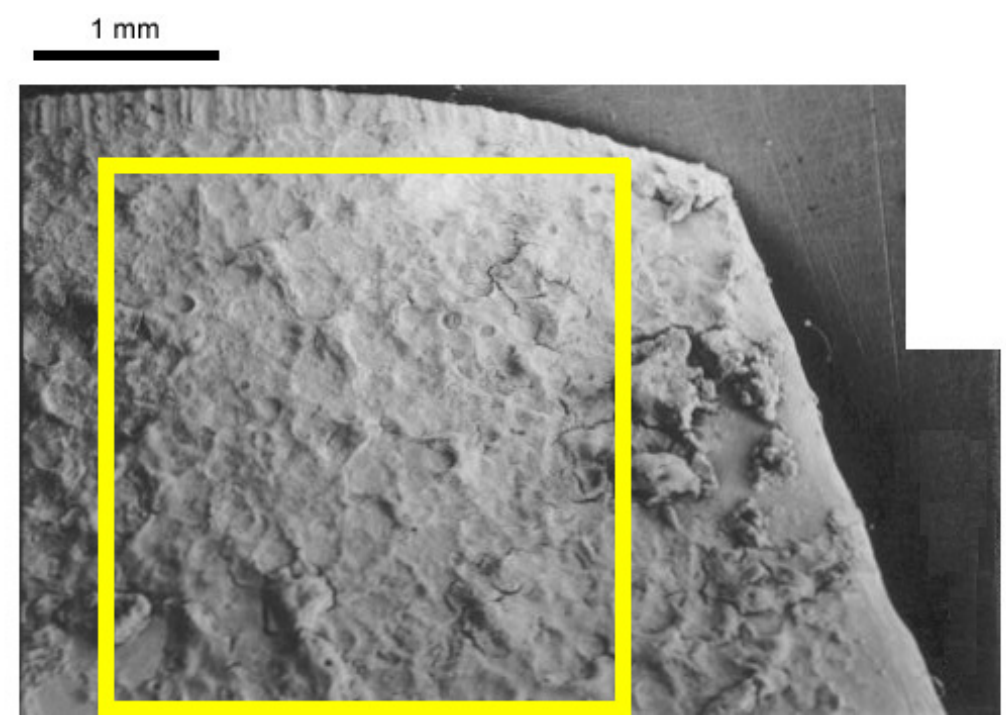

FIG. 16: X-ray spectrum from selected area in FIG. 15

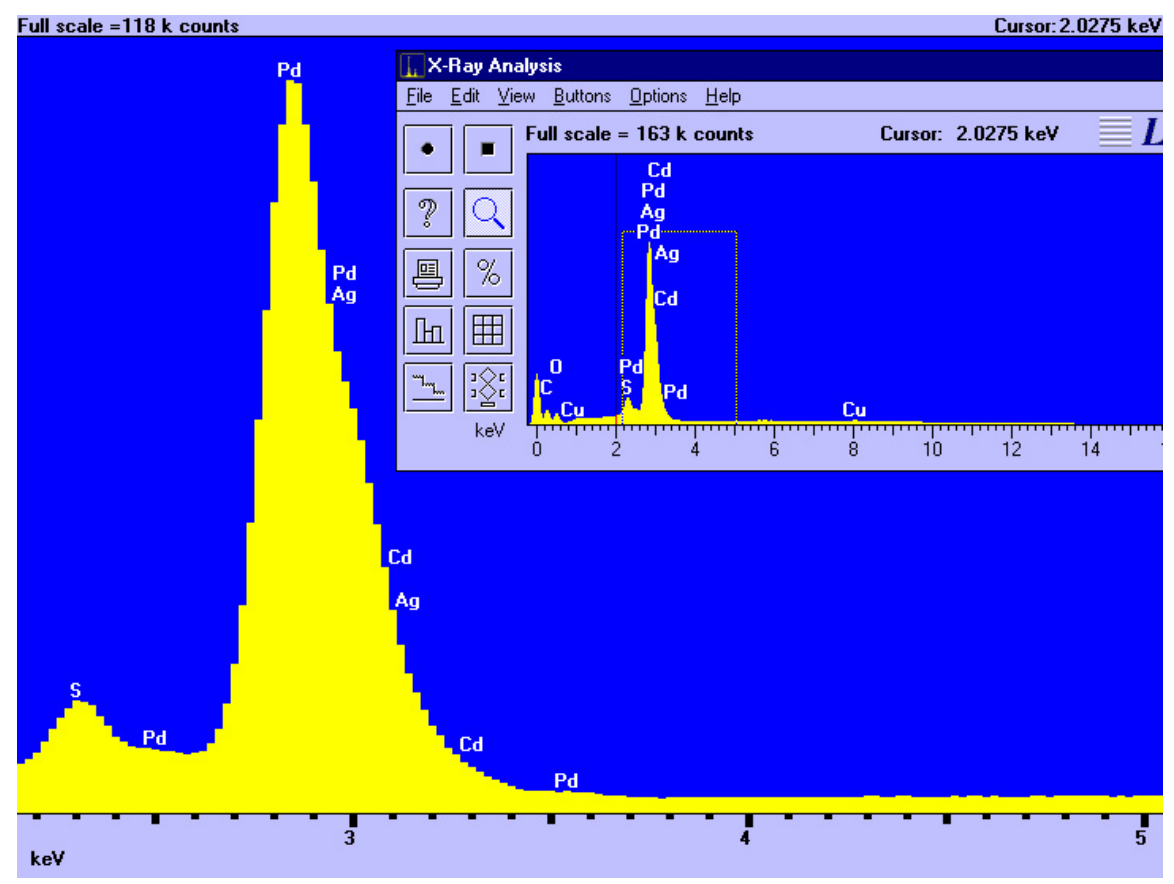


Table 9: Results of elemental analysis of spectrum of FIG. 16, from selected area in FIG. 15.

\begin{tabular}{lrrr}
\multicolumn{5}{c}{$\begin{array}{l}\text { In number } \\
\text { of atoms }\end{array}$} & \multicolumn{2}{l}{ In mass } & \multicolumn{2}{l}{$\begin{array}{l}\text { O } \text { in mass } \\
\text { C }\end{array}$} & $12.87 \%$ & $3.21 \%$ & $0.07 \%$ \\
$\mathrm{O}$ & $47.04 \%$ & $15.59 \%$ & $0.20 \%$ \\
$\mathrm{~S}$ & $4.55 \%$ & $3.02 \%$ & $0.04 \%$ \\
$\mathrm{Cu}$ & $0.71 \%$ & $0.94 \%$ & $0.09 \%$ \\
$\mathrm{Pd}$ & $33.14 \%$ & $73.04 \%$ & $0.31 \%$ \\
$\mathrm{Ag}$ & $1.43 \%$ & $3.19 \%$ & $0.25 \%$ \\
$\mathrm{Cd}$ & $0.00 \%$ & $0.00 \%$ & $0.19 \%$ \\
$\mathrm{Pt}$ & $0.26 \%$ & $1.03 \%$ & $0.08 \%$
\end{tabular}

(Surface analysis up to a depth of $\sim 1 \mu \mathrm{m}$ ).

Table 10: Results of analysis of spectrum of FIG. 16, from selected area in FIG. 15 (metallic elements)

\begin{tabular}{lrrr}
\multicolumn{5}{c}{$\begin{array}{l}\text { In number } \\
\text { of atoms }\end{array}$} & In mass & \multicolumn{2}{l}{ 更 } \\
& $1.99 \%$ & $1.20 \%$ & $0.11 \%$ \\
$\mathrm{Cu}$ & $93.26 \%$ & $93.42 \%$ & $0.39 \%$ \\
$\mathrm{Pd}$ & $4.02 \%$ & $4.07 \%$ & $0.32 \%$ \\
$\mathrm{Ag}$ & $0.00 \%$ & $0.00 \%$ & $0.24 \%$ \\
$\mathrm{Cd}$ & $0.73 \%$ & $1.31 \%$ & $0.10 \%$ \\
$\mathrm{Pt}$ & & &
\end{tabular}

(Surface analysis up to a depth of $\sim 1 \mu \mathrm{m}$ ).

For more micrographs and spectra from the D cell cathode of this second experiment, please refer to Appendix $\mathrm{H}$. 


\section{DISCUSSION:}

\section{Thermal factors:}

Thermodynamic considerations:

In steady-state the amount of energy per unit time that goes into any closed system, such as an imaginary box encompassing the electrodes in this experiment, must equal the amount of energy that leaves the system:

\section{Power in $=$ Power out}

The terms that contribute to this power balance in this particular experiment will be listed in order of importance:

-Terms in the Power-out side: i.e., terms that contribute to the total power that the electrodes must produce to maintain the steady-state: 
The Electrolysis term, which will be denoted $\frac{d H_{\mathrm{H}_{2} \mathrm{O}}}{d t}$ for the $\mathrm{H}$ (light water) cell and $\frac{d H_{\mathrm{D}_{2} \mathrm{O}}}{d t}$ for the $\mathrm{D}$ (heavy water) cell. It is the energy per unit time spent by the cells in electrolyzing the water, according to:

$\mathrm{H}_{2} \mathrm{O}(l) \rightarrow \mathrm{H}_{2}(\uparrow)+\frac{1}{2} \mathrm{O}_{2}(\uparrow)$

.. ... for the light water cell or.. ..

$\mathrm{D}_{2} \mathrm{O}(l) \rightarrow \mathrm{D}_{2}(\uparrow)+\frac{1}{2} \mathrm{O}_{2}(\uparrow)$

.....for the heavy water cell.

The enthalpy for this reaction is of course the opposite of the enthalpy of formation $\Delta H_{f}^{o}$ of water (or heavy water) listed in the tables (Lide, 1993), and equates to $285,900 \frac{J}{m o l e}$ for the light water electrolysis and 294,700 $\frac{J}{m o l e}$ for the heavy water electrolysis, at $25{ }^{\circ} \mathrm{C}$ and 1 atmosphere. Both molecular hydrogen (or deuterium) and oxygen are already gaseous at $25{ }^{\circ} \mathrm{C}$ and hence no extra enthalpy is required to vaporize them in the temperature range of this experiment.

Hence the electrolysis term for the light (or heavy) water cell is the product of the absolute value of the enthalpy of formation of light (or heavy) water, 
times the rate of light (or heavy) water mass loss in the cell due to electrolysis, divided by the molecular mass of light (or heavy) water. That is:

$$
\begin{aligned}
& \frac{d H_{\mathrm{H}_{2} \mathrm{O}}}{d t}=285,970 \frac{J}{\text { mole }} \cdot \frac{d \mathrm{~m}_{\mathrm{H}_{2} \mathrm{O}}}{d t} \cdot \frac{1}{18.00 \text { grams } / \text { mole }} \\
& \frac{d H_{\mathrm{D}_{2} \mathrm{O}}}{d t}=294,750 \frac{J}{\text { mole }} \cdot \frac{d \mathrm{~m}_{\mathrm{D}_{2} \mathrm{O}}}{d t} \cdot \frac{1}{20.00 \text { grams } / \text { mole }}
\end{aligned}
$$

- The Evaporation term, which will be denoted $\frac{d H_{\mathrm{H}_{2} \mathrm{O}, \mathrm{ev}}}{d t}$ for the $\mathrm{H}$ (light water) cell and $\frac{d H_{\mathrm{D}_{2} \mathrm{O}, \mathrm{ev}}}{d t}$ for the $\mathrm{D}$ (heavy water) cell. This term expresses the energy that must be supplied by the system in order to counterbalance the cooling caused by the passive evaporation of the electrolyte. It is the product of the enthalpy of vaporization of light water (or heavy water) times the number of moles of light water (or heavy water) that evaporate per unit time.

The enthalpy of vaporization of water (or heavy water), is, of course, temperature-dependant, because it takes less and less energy to vaporize a given mass of water (or heavy water) as one approaches the boiling point. 
Nevertheless it is more than safe in the temperature range of this experiment to assume a constant enthalpy of vaporization of:

$\Delta H_{\mathrm{ev}, \mathrm{H}_{2} \mathrm{O}}=45050 \frac{\mathrm{J}}{\text { mole }}$

for light water and:

$\Delta H_{\mathrm{ev}, \mathrm{D}_{2} \mathrm{O}}=45042 \frac{\mathrm{J}}{\text { mole }}$

for heavy water (Lide, 1993).

The rate of mass loss due to evaporation is also temperature-dependent. As the temperature of any liquid increases, it tends to evaporate more and more. The rate of mass loss to evaporation of a liquid at any given temperature is proportional to the vapor pressure (it also depends on other factors such as the air speed over the liquid, but these are not relevant in this experiment in which the cells were covered with a Teflon top). With the Teflon top on, the average evaporation rate of the $\mathrm{H}$ cell at room temperature $\left(20^{\circ} \mathrm{C}\right)$ was observed to be $0.0060 \pm 0.0004 \frac{\text { grams }}{\text { hour }}$, and the basal (room temperature) evaporation rate of the D cell was found to be $0.0017 \pm 0.0004 \frac{\text { grams }}{\text { hour }}$. 
There is still of course the evaporation of the sulfuric acid part of the electrolyte, but this can be completely neglected. At $145.8{ }^{\circ} \mathrm{C}$, when no water (or heavy water) survives in the liquid state at 1 atmosphere of pressure, a liquid pool of sulfuric acid still exerts only 1 torr of pressure, or 1/760 of an atmosphere (Lide, 1993). (At $194.2{ }^{\circ} \mathrm{C}$ the vapor pressure of sulfuric acid has only risen to 10 torr, 1/76 of an atmosphere, a vapor pressure that is reached by light water at $11.6{ }^{\circ} \mathrm{C}$ and by heavy water at 13.3 $\left.{ }^{\circ} \mathrm{C}\right)$ (Lide, 1993). The actual combined phase diagram of the $\mathrm{H}_{2} \mathrm{SO}_{4}-\mathrm{H}_{2} \mathrm{O}$ system is rather complicated, and further enriched by the presence of eutectic hydrates such as $\mathrm{H}_{2} \mathrm{SO}_{4} \cdot \mathrm{H}_{2} \mathrm{O}$, which melts at $8.5{ }^{\circ} \mathrm{C}$, and $\mathrm{H}_{2} \mathrm{SO}_{4} \cdot 2 \mathrm{H}_{2} \mathrm{O}$, which melts at $-38{ }^{\circ} \mathrm{C}$ (Sander et al., 1984; Cotton, 1988). However, this does not detract from the validity of the argument: dissociated sulfuric acid molecules will exert no appreciable vapor pressure whether they may be hydrated or not.

- The Heat dissipation term. It expresses the power that must be continuously generated by electrolysis to maintain the temperature gradient between the electrolyte and the background of the lab. If a warm system at temperature $T_{\text {warm }}$ is separated by a wall of surface $A$ and thickness $\delta$ from its colder surroundings at temperature $T_{\text {cold, }}$, the rate of heat loss by the system is given by (Hemminger and Hohne, 1984; Morse, 1969): 
$P_{\text {loss }}=\kappa \cdot \frac{A}{\delta} \cdot\left(T_{\text {warm }}-T_{\text {cold }}\right)$

with $\kappa$ the thermal conductivity of the separating wall. Now, if one considers again an imaginary box containing the space around the electrodes inside the electrolyte where the action of the experiment takes place, the box can then be modeled to be at a uniform temperature $T$, the average of all the thermocouple and sensor readings at each moment. The combined contributions in each cell of the beaker wall, the Teflon top and the electrolyte itself, with their varying geometries, surfaces and thicknesses, can then be very roughly summarized in a single linear thermal conductance term, which will be denoted by $R$ :

$P_{\text {loss }}=R\left(T-T_{\text {ambient }}\right)$

This might look like a rather crude model, but considerable effort was expended in assembling the two cells as similar to each other as possible so that the effective $R$ would be the same in both cells.

There are deviations, of course, not the least important of which is the difference in electrolyte level and composition between the cells, which affects the thermal conductivity. For any given mixture of water and sulfuric acid, as the concentration of sulfuric acid increases the thermal conductivity decreases, at any given temperature. Similarly, for any given concentration of sulfuric acid, as the temperature of the mixture increases 
the thermal conductivity decreases. In the $20-80{ }^{\circ} \mathrm{C}$ range this double temperature and concentration dependence of the thermal conductivity of the $\mathrm{H}_{2} \mathrm{O} \cdot \mathrm{H}_{2} \mathrm{SO}_{4}$ system can be summarized as (Vargaftik, 1975):

$\kappa_{(x, T)} \approx\left[0.6024-0.0028 x+(0.00062166+0.0833 x)\left(\frac{T}{{ }^{o} C}-20\right)\right] \frac{W}{m \cdot{ }^{o} C}$

... ... with $x$ the unit concentration of $\mathrm{H}_{2} \mathrm{SO}_{4}$ by weight. ( $m$ stands for meter).

The very Teflon used in the columns, which is a solid polymer $\left(\mathrm{C}_{2} \mathrm{~F}_{4}\right)_{\mathrm{n}}$, has a thermal conductivity which is temperature-dependent. A good fit of this temperature dependence is (Lide, 1993):

$\kappa_{\left(\mathrm{C}_{2} \mathrm{~F}_{4}\right)_{\mathrm{n}}(T)}=\left[-0.0031 \frac{T}{{ }^{o} C}+2.3294\right] \frac{W}{m \cdot{ }^{o} \mathrm{C}}$

The pyrex glass of the cell beakers, which is made of $80-81 \% \mathrm{SiO}_{2}, 12-13 \%$ $\mathrm{B}_{2} \mathrm{O}_{3}, 4 \% \mathrm{Na}_{2} \mathrm{O}$ and $2 \% \mathrm{Al}$, also has a thermal conductivity with some temperature dependence, which is closely approximated by (Lide, 1993):

$\kappa_{\operatorname{pyrex}(T)}=\left[-10^{-5}\left(\frac{T}{{ }^{o} C}\right)^{2}+0.0069 \frac{T}{{ }^{o} C}-0.0204\right] \frac{W}{m \cdot{ }^{o} C}$

..... in the temperature range of this experiment.

The effects of temperature and sulfuric acid concentration variations on the total thermal conductivity throughout the experiment could not be neglected in a large-scale experiment in which the temperature variations within the 
electrolyte were accurately recorded with high-precision, fast-response sensors. In this very rudimentary, small-sized experiment, though, it is not worthwhile to fret over second-order and third-order effects. Still, a few simple calculations show that, if one of the two cells had a higher thermal conductivity, it was the D cell, which means that heat would have been escaping more easily from the $\mathrm{D}$ cell than from the $\mathrm{H}$ and that a possible excess heat measurement in the $\mathrm{D}$ cell relative to the $\mathrm{H}$ would be further supported. The main reasons are as follows:

*Firstly, the D cell had a slightly lighter Teflon top (79.03 grams for 80.47 grams).

*Secondly, the D cell Teflon top was very slightly thinner than that of the $\mathrm{H}$ cell: repeated measurements with the micrometer gave thicknesses of $14.710,14.740,14.740,14.725,14.707,14.702$ and $14.735 \mathrm{~mm}$ for the D cell Teflon top and $14.890,14.769,14.922$ and $14.912 \mathrm{~mm}$ for the $\mathrm{H}$ cell top. Teflon was the main insulator in this experiment: its $2.2198 \frac{\mathrm{W}}{\mathrm{m} \cdot{ }^{\circ} \mathrm{C}}$ thermal conductivity at $35{ }^{\circ} \mathrm{C}$ can be contrasted with the 0.20885 $\frac{W}{m \cdot{ }^{o} \mathrm{C}}$ conductivity of the pyrex glass at the same temperature. By comparison, a $25.09 \%$ by weight solution of $\mathrm{H}_{2} \mathrm{SO}_{4}$ in $\mathrm{H}_{2} \mathrm{O}$, such as the 
initial electrolyte solution of the $\mathrm{D}$ cell at the beginning of the experiment, has a thermal conductivity of $0.9245 \frac{\mathrm{W}}{\mathrm{m} \cdot{ }^{\circ} \mathrm{C}}$ at $35^{\circ} \mathrm{C}$.

*Thirdly, the lead wires had the same diameter in both cells for both the anodes and the cathodes. The escape of heat through the little space of air between the lead wire and the insulating Teflon top was not particularly favored in any cell.

*Fourthly, the thermal conductivity of the $\mathrm{H}$ cell electrolyte was on average always less than that of the $\mathrm{D}$ cell. This can be shown easily by noting that the concentration of sulfuric acid by weight in the $\mathrm{H}$ cell electrolyte could never have exceeded the original mixed mass of $\mathrm{H}_{2} \mathrm{SO}_{4}, 2.34$ grams, divided by the total mass of electrolyte at the end of the experiment, which was 55.63 grams -40.91 grams $=14.71$ grams: it was after the last electrolysis run when the sulfuric acid in the $\mathrm{H}$ electrolyte was most concentrated. An upper bound on the $\mathrm{H}$ cell electrolyte conductivity can then be found by putting this maximum sulfuric acid weight concentration $x$ of $\frac{2.34}{14.71}=15.90 \%$ into formula (7). The thermal conductivity upper bound for the $\mathrm{H}$ cell turns out to be, at $35^{\circ} \mathrm{C}$ :

$\left[0.6024-0.0028 \cdot 0.159+(0.00062166+0.0833 \cdot 0.159) \cdot 15^{\circ} \mathrm{C}\right] \frac{W}{m \cdot{ }^{o} \mathrm{C}}=$ 
$=0.810 \frac{\mathrm{W}}{\mathrm{m}^{\circ}{ }^{o} \mathrm{C}}$

Similarly, a lower bound on the D cell electrolyte conductivity throughout the experiment can be found by dividing the minimum mass of $\mathrm{H}_{2} \mathrm{SO}_{4}$ that had certainly been mixed in the electrolyte, 13.95 grams, by the total mass of electrolyte at the beginning of the experiment, 62.08 grams, when the sulfuric acid in the D cell was most diluted; and then by putting this minimum sulfuric acid weight concentration $x$ of $\frac{13.95}{62.08}=22.47 \%$ in formula (7). This gives a thermal conductivity lower bound of:

$\left[0.6024-0.0028 \cdot 0.2247+(0.00062166+0.0833 \cdot 0.2247) \cdot 15^{\circ} \mathrm{C}\right] \frac{W}{m \cdot{ }^{o} \mathrm{C}}=$ $=0.892 \frac{W}{m \cdot{ }^{o} C}$

for the $\mathrm{D}$ cell. More generally, at any temperature $T$, the thermal conductivity of the D cell electrolyte minus the thermal conductivity of the $\mathrm{H}$ cell electrolyte must have always exceeded:

$$
\begin{aligned}
& {\left[-0.0028 \cdot(0.2247-0.159)+0.0833 \cdot(0.2247-0.159) \cdot\left(\frac{T}{{ }^{o} C}-20\right)\right] \frac{W}{m \cdot{ }^{o} C}} \\
& =0.0657 \cdot\left[0.0833\left(\frac{T}{{ }^{o} C}-20\right)-0.0028\right] \frac{W}{m \cdot{ }^{o} C}
\end{aligned}
$$


, which was always positive in the working temperature range $T>20.04{ }^{\circ} \mathrm{C}$ of this experiment.

Hence it is more than safe to ignore the possible small difference in thermal conductivity between the cells and treat $R$ as the same for both cells in this experiment.

-Terms in the Power-in side: i.e., terms that contribute to the total power that is supplied to the electrodes:

- The Electrical power term, which is the power supplied by the circuit to the electrodes. It is simply given by the product of the voltage at which the cell is maintained times the current:

$P_{\text {in }}=V I$

- The loading term, $\frac{d H_{\mathrm{PdH}_{\mathrm{x}}}}{d t}$ which is the energy released per unit time at the cathode due to the loading of hydrogen (or deuterium in the case of the heavy water cell) into the palladium (Hurd, 1952; Mueller et al., 1968; Flanagan and Oates, 1978; Dedieu, 1992): 
$\mathrm{Pd}(\mathrm{s})+\frac{x}{2} \mathrm{H}_{2}(\mathrm{~g}) \rightarrow \mathrm{PdH}_{\mathrm{x}}(\mathrm{s})$

$x$ is the degree of loading of hydrogen in palladium hydride. Palladium is unique among the transition metals for its ability to absorb huge amounts of hydrogen, a remarkable fact that was first discovered by Graham in 1866 (Flanagan and Oates, 1978).

$\mathrm{PdH}_{\mathrm{x}}$ is not a stoichiometric compound but an interstitial compound in which the hydrogen atoms fill up the octahedral interstices in the facecentered cubic crystal lattice of palladium as $x$ increases. The crystal lattice cell then expands from its normal edge size $a=0.3883 \mathrm{~nm}$ to $a=0.3894 \mathrm{~nm}$ (Flanagan and Oates, 1978), then it undergoes a rapid dilation to $a=0.408$ $\mathrm{nm}$ and keeps swelling if hydrogen continues to be added (FIG. 17).

Experimentally, palladium samples have been made to absorb hydrogen up to 1000 times their volume (Flanagan and Oates, 1978).

It is thought that hydrogen is initially absorbed through cracks in the metal structure of palladium, and the previous history of the Pd sample can have a marked effect on the absorption rate. For instance, a vacuum-annealed $\mathrm{Pd}$ sample absorbs hydrogen very laggardly, but a Pd sample that had previously absorbed hydrogen and then had the hydrogen brusquely removed by vacuum treatment at room temperature quickly re-sponges hydrogen. 
During loading, the diffusion of hydrogen into the rifts is followed by the alloying of hydrogen with palladium around the rifts. That is to say, an effective solid solution of metallic hydrogen is formed, the so-called $\alpha$ phase of $\mathrm{PdH}$. Once formed, this alloy is stable for long periods at room temperature, even in vacuum conditions. Only at high temperatures in vacuum will the hydrogen slowly begin to diffuse away (Flanagan and Oates, 1978).

There are no oxidation problems associated with palladium. The enthalpy of formation $\Delta H_{f}^{o}$ of the half-loaded palladium hydride, $\mathrm{PdH}_{0.5}$ is generally given as $-37,200 \frac{J}{m o l e}$ (Rossini, 1961).

Until the 1970s, there was no reliable thermodynamic data for hydrogen dissolved in bulk palladium below 400 Kelvin due to the slowness of the $\mathrm{H}_{2} \stackrel{\leftarrow}{\rightarrow} 2 \mathrm{H}$ chemisorption at the surface (Flanagan and Oates, 1978). In fact, Pd-H was the first nonstoichiometric system for which detailed thermodynamic data were obtained.

Only recently was it found that absorption of hydrogen by palladium leads to two nonstoichiometric phases for $\operatorname{PdH}_{\mathrm{x}}\left(\right.$ or $\left.\operatorname{PdD}_{\mathrm{x}}\right):(\alpha)$, and $(\beta)$, in which hydrogen (or deuterium) gradually occupies the octahedral interstices of the face-centered-cubic cell shown in FIG. 17 as $x$ increases. At 1 atmosphere the $\alpha$ phase preponderates below $x=0.7$; above that level of loading $\mathrm{PdH}_{\mathrm{x}}$ 
(or $\mathrm{PdD}_{\mathrm{x}}$ ) is present only in the $\beta$ phase (FIGS. 18 and 19). In both phases hydrogen atoms occupy the interstices within the face-centered-cubic palladium lattice and the main difference is in the hydrogen content and in the lattice parameters of the matrix of enveloping palladium.

The work of Baranowski et al. has demonstrated that the amount by which the volume of palladium expands per added hydrogen atom is the same for both the $\alpha$ and $\beta$ phases, up to a loading of $x=0.75$ (Flanagan and Oates, 1978). This partial molar volume of hydrogen $V_{\mathrm{H}}$ is $1.65 \frac{\mathrm{cm}^{3}}{\mathrm{~mol} \mathrm{H}}$. At $x=$ 0.75 the partial molar volume seems to drop to $0.4 \frac{\mathrm{cm}^{3}}{\mathrm{~mol} \mathrm{H}}$, something which has been related to the onset of superconductivity in palladiumhydrogen. It has been pointed out that in the $\alpha$ phase hydrogen occupies interstices that have tetrahedral coordination with respect to $\mathrm{Pd}$, but the difference between the two phases of the Pd-H system is still not thoroughly understood (Fukai, 1981). 
FIG. 17.: Crystal unit cell of $\beta-\mathrm{PdH}_{\mathrm{x}}$ (or $\beta-\mathrm{PdD}_{\mathrm{x}}$ ). It expands as $\mathrm{x}$ increases.

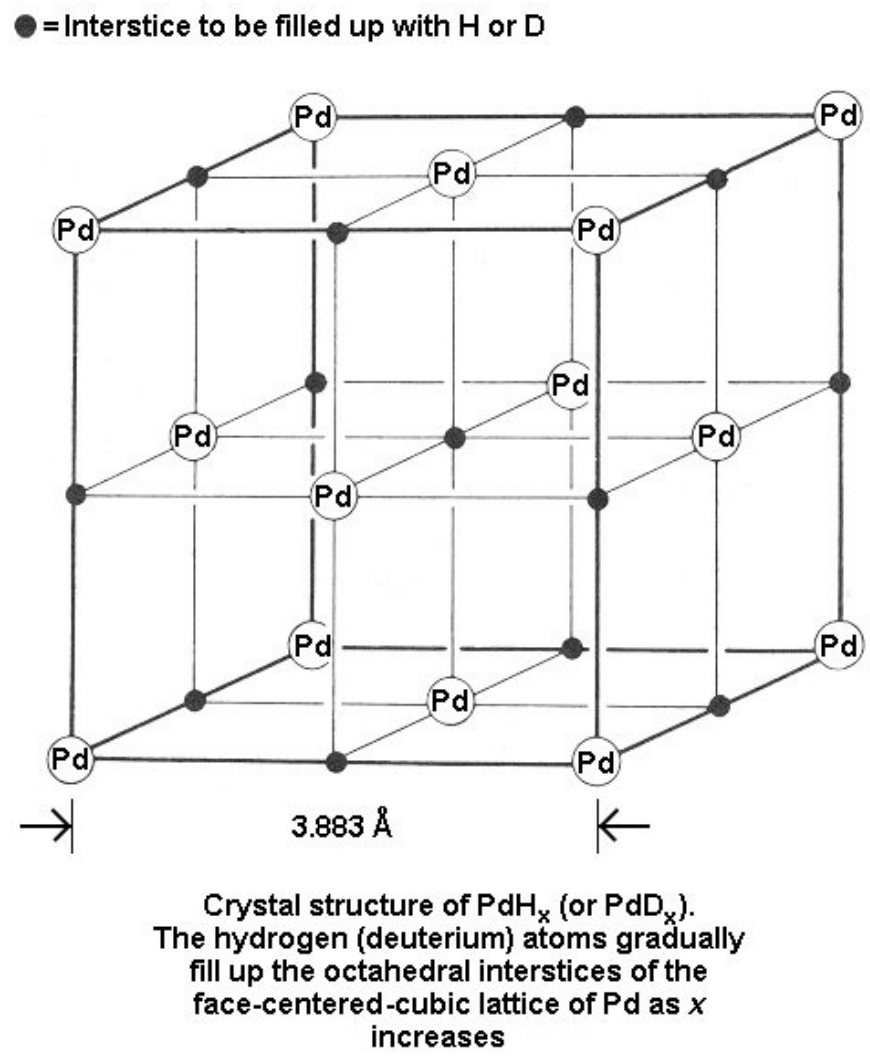

In 1937 Lacher used a statistical mechanical model to account for the phase diagram of $\mathrm{PdH}_{x}$ that was later used for many other studies of nonstoichiometric systems. His model successfully predicted many features of $\mathrm{PdH}_{x}$ known at the time even though it was based on the somewhat shortsighted assumption that the limiting value for the loading $x$ was 0.59 , and subsequent experimental work has repeatedly succeeded in achieving values of the loading $x$ very close to 1 . 
For instance, Flanagan and Oates have loaded palladium samples to $x=$ $0.99 \pm 0.01$ charging them with hydrogen atoms from the gas phase. Then there are the electrochemical methods and the high-pressure methods (Flanagan and Oates, 1978).

FIG. 18: Phase diagram of $\mathrm{PdH}_{\mathrm{x}}\left(\right.$ or $\mathrm{PdD}_{\mathrm{x}}$ ) at 1 atm. (Darling, 1973)

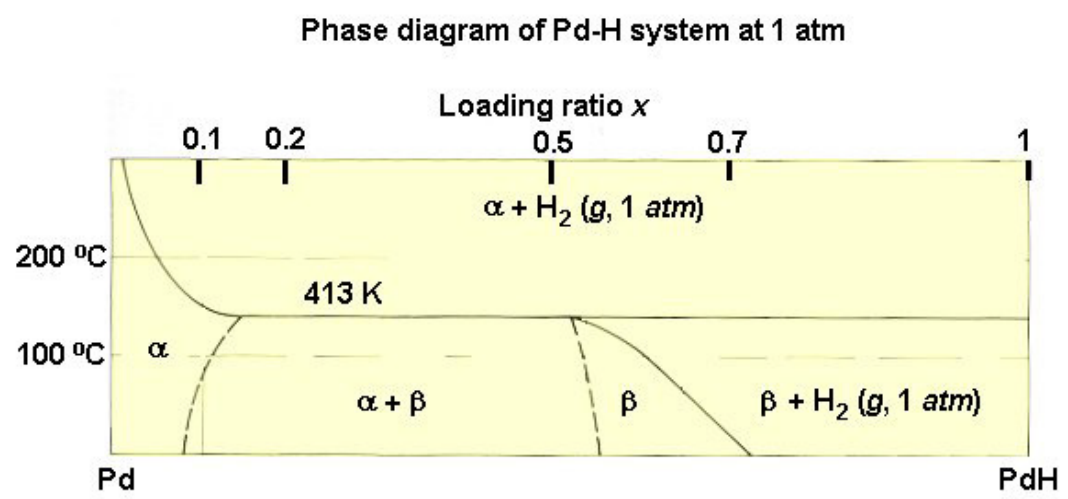

The unsheathed portion of the Pd cathode in both cells of the experiment had dimensions of $2.15 \mathrm{~cm} \times 0.55 \mathrm{~cm} \times 0.027 \mathrm{~cm}$ and hence, given the lot's label density for this particular palladium of $12.02 \mathrm{~g} / \mathrm{cm}^{3}$, the mass of this unsheathed portion was 0.383 grams. This means that the unsheathed portion of each cathode hosted $\frac{0.383 \mathrm{~g}}{106.4 \mathrm{~g} / \text { mole }}=0.0036$ moles of palladium metal. Therefore the enthalpy loading term is:

$$
\frac{d H_{\mathrm{PdH}_{\mathrm{x}}}}{d t} \approx \frac{d x}{d t} \cdot 0.0036 \text { moles } \cdot 74500 \frac{J}{\text { mole }}
$$


.. .. with $\frac{d x}{d t}$ the rate of loading. (The rough assumption, by no means justified, that the enthalpy of formation of the fully loaded hydride is twice that of the half-loaded hydride has been made). For the D cell the formula must be taken to be the same as the tables do not list a separate formation enthalpy for the deuteride.

FIG. 19: General phase diagram of $\mathrm{PdH}_{\mathrm{x}}\left(\right.$ or $\left.\mathrm{PdD}_{\mathrm{x}}\right)$. (Darling, 1973).

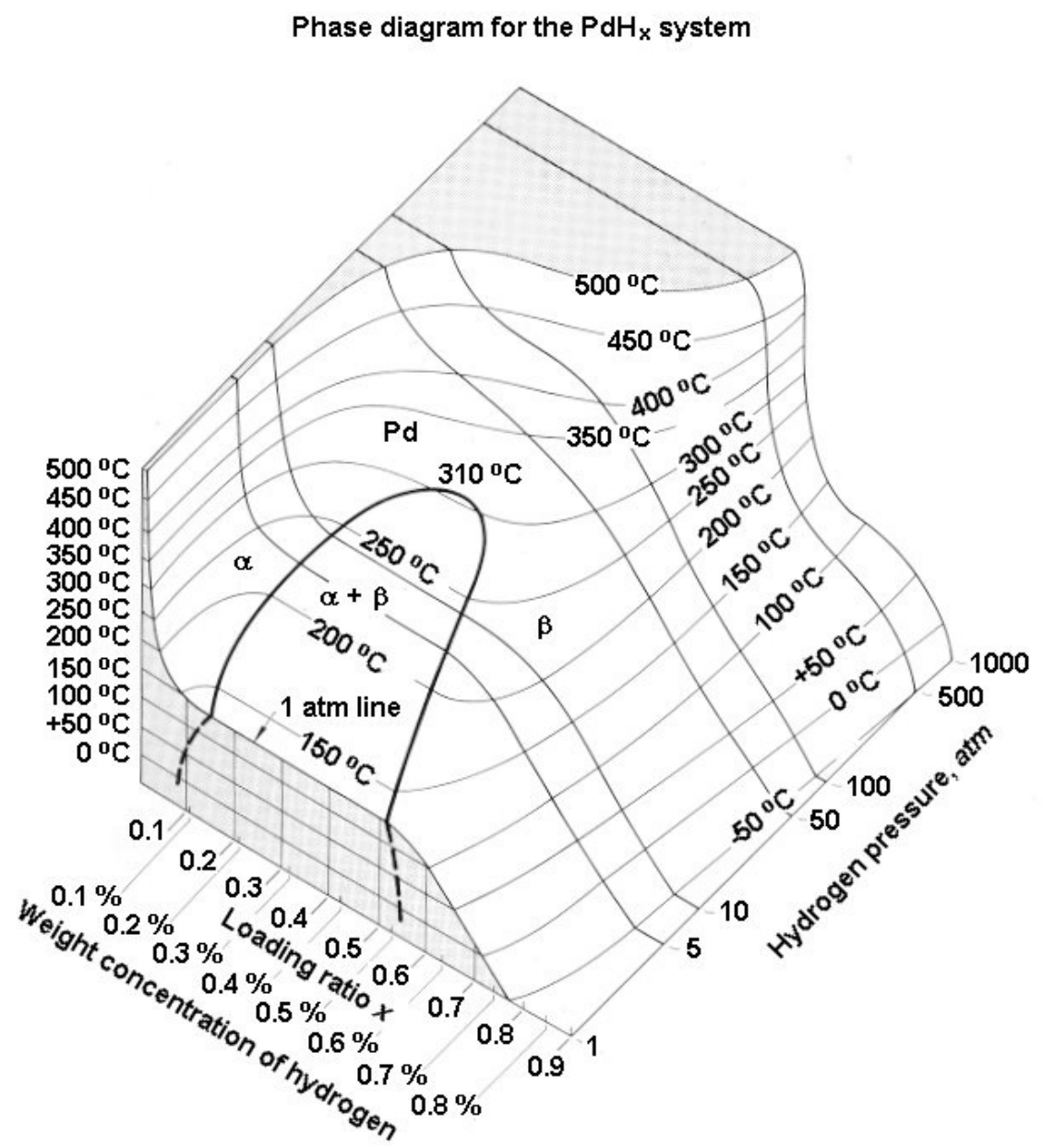


There are however indications that the palladium-hydrogen force constant could be as much as $20 \%$ stronger than the palladium-deuterium force constant at $x=0.63$ (Rahman et al., 1976). If so, the formation enthalpy of $\mathrm{PdD}_{\mathrm{x}}$ would be somewhat less negative than that of $\mathrm{PdH}_{\mathrm{x}}$.

The loading rate $\frac{d x}{d t}$ varies with time and depends on many factors (Azzarone et al., 2000; Zhang et al., 2000). How fast the cathode loads is really irrelevant in this experiment as what counts is the average loading enthalpy release rate over the whole duration of the runs.

- The excess heat term, $\frac{d H_{\text {excess }}}{d t}$ is the object of interest. The goal of this experiment is to determine if there was an unaccounted-for extra source of energy. It is not possible to deduce the absolute amount of this unaccounted-for energy that may have gone to each cell, as balancing the power that goes in with the power that goes out leaves only two equations (one for each cell), and there is already one unknown that must be solved out: the common thermal conductivity term $R$. Hence it has to be assumed that the $\mathrm{H}$ cell acted as control cell and produced no excess heat. That is to say, the goal will be to find out the excess heat that the $\mathrm{D}$ cell produced relative to the $\mathrm{H}$ cell. 
This is done simply by bringing all the terms of the power balance equation together for each cell:

$$
\begin{aligned}
& P_{\mathrm{in}, \mathrm{H}}+\frac{d H_{\mathrm{PdH}_{\mathrm{x}}}}{d t}=\frac{d H_{\mathrm{H}_{2} \mathrm{O}, \mathrm{ev}}}{d t}+\frac{d H_{\mathrm{H}_{2} \mathrm{O}}}{d t}+R\left(T_{\mathrm{H}}-T_{\text {ambient }}\right) \\
& \frac{d H_{\text {excess }}}{d t}+P_{\mathrm{in}, \mathrm{D}}+\frac{d H_{\mathrm{PdD}_{\mathrm{x}}}}{d t}=\frac{d H_{\mathrm{D}_{2} \mathrm{O}, \mathrm{ev}}}{d t}+\frac{d H_{\mathrm{D}_{2} \mathrm{O}}}{d t}+R\left(T_{\mathrm{D}}-T_{\text {ambient }}\right)
\end{aligned}
$$

Solving for $R$ in the $\mathrm{H}$ cell formula and substituting in the $\mathrm{D}$ cell formula the following is obtained:

$$
\begin{aligned}
& R=\left[P_{\mathrm{in}, \mathrm{H}}-\frac{d H_{\mathrm{H}_{2} \mathrm{O}, \mathrm{ev}}}{d t}-\frac{d H_{\mathrm{H}_{2} \mathrm{O}}}{d t}+\frac{d H_{\mathrm{PdH}_{\mathrm{x}}}}{d t}\right] \frac{1}{\left(T_{\mathrm{H}}-T_{\text {ambient }}\right)} \\
& \frac{d H_{\text {excess }}}{d t}=-P_{\mathrm{in}, \mathrm{D}}+\frac{d H_{\mathrm{D}_{2} \mathrm{O}, \mathrm{ev}}}{d t}+\frac{d H_{\mathrm{D}_{2} \mathrm{O}}}{d t}+R\left(T_{\mathrm{D}^{-}} T_{\text {ambient }}\right)-\frac{d H_{\mathrm{PdD}_{\mathrm{x}}}}{d t}
\end{aligned}
$$

$$
\begin{aligned}
& =-P_{\mathrm{in}, \mathrm{D}}+\frac{d H_{\mathrm{D}_{2} \mathrm{O}, \mathrm{ev}}}{d t}+\frac{d H_{\mathrm{D}_{2} \mathrm{O}}}{d t}-\frac{d H_{\mathrm{PdD}_{\mathrm{x}}}}{d t}+ \\
& +\left[P_{\mathrm{in}, \mathrm{H}}-\frac{d H_{\mathrm{H}_{2} \mathrm{O}, \mathrm{ev}}}{d t}-\frac{d H_{\mathrm{H}_{2} \mathrm{O}}}{d t}+\frac{d H_{\mathrm{PdH}_{\mathrm{x}}}}{d t}\right] \frac{T_{D}-T_{\text {ambient }}}{T_{\mathrm{H}}-T_{\text {ambient }}}
\end{aligned}
$$

A few observations are in order. The power-in terms $\left(P_{\mathrm{in}, \mathrm{H}}\right.$ and $\left.P_{\mathrm{in}, \mathrm{D}}\right)$ and electrolysis terms $\left(\frac{d H_{\mathrm{H}_{2} \mathrm{O}}}{d t}\right.$ and $\left.\frac{d H_{\mathrm{D}_{2} \mathrm{O}}}{d t}\right)$ are the dominant ones, the first are of 
about $\sim 2$ watts and the latter of about $\sim 1$ watt. The evaporation terms $\left(\frac{d H_{\mathrm{H}_{2} \mathrm{O}, \mathrm{ev}}}{d t}\right.$ and $\left.\frac{d H_{\mathrm{D}_{2} \mathrm{O}, \mathrm{ev}}}{d t}\right)$ are far smaller $(\sim 0.008$ watts $)$ and the loading terms $\left(\frac{d H_{\mathrm{PdH}_{\mathrm{x}}}}{d t}\right.$ and $\left.\frac{d H_{\mathrm{PdD}_{\mathrm{x}}}}{d t}\right)$ are smaller still $(\sim 0.0003$ watts $)$. The $\mathrm{H}$ cathode loading term, which contributes positively to the excess heat, can be ignored. The goal is to arrive at an excess heat estimate for the D cell as conservative as possible.

\section{Heat results:}

There are two ways to estimate the electrolysis terms $\frac{d H_{\mathrm{H}_{2} \mathrm{O}}}{d t}$ and $\frac{d H_{\mathrm{D}_{2} \mathrm{O}}}{d t}$ and hence the excess heat.

\section{-Estimation based on the mass losses of the cells:}

In this method, the cells are weighed before and after electrolysis, and the mass difference, divided by the time of electrolysis gives the average $\frac{d \mathrm{~m}_{\mathrm{H}_{2} \mathrm{O}}}{d t}$ term (for the $\mathrm{H}$ cell) or the average $\frac{d \mathrm{~m}_{\mathrm{D}_{2} \mathrm{O}}}{d t}$ term (for the $\mathrm{D}$ cell), which are then plugged into equations (1) or (2) respectively. 
Actually, some of the mass loss is due to passive evaporation through the unsealed Teflon top, so an estimate of this passive dragout of light water (in the $\mathrm{H}$ cell) or heavy water (in the D cell) based on the observed evaporation rates at room temperature must be made and subtracted from the mass difference between weighings to arrive at the mass loss due to electrolysis.

For example, in the second experiment, during the period from December 262001 at 2:39 PM when the cells were weighed and January 252002 at 9:40 AM when the cells were weighed again, there were 41461 minutes, of which 7666 were of electrolysis.

During this total period the $\mathrm{H}$ cell lost a total of 38.07 grams. From these, it was then estimated based on the basal evaporation rate measured for this cell that about 4.89 grams were due to passive evaporation.

Similarly, during this period the D cell lost a total of 30.02 grams. From these, it was estimated based on the basal evaporation rate measured for this cell that about 1.40 grams were due to passive evaporation.

The excess heat formula was then applied to the steady-state periods of electrolysis when the cells had already reached operating temperature above $\sim 30{ }^{\circ} \mathrm{C}$ and both the temperatures and the voltages remained steady. The excess power derived from the formula at each minute was then numerically integrated to find the total excess heat produced by the $\mathrm{D}$ cell in this experiment during steady-state. 
The evaporation terms $\frac{d H_{\mathrm{H}_{2} \mathrm{O}, \mathrm{ev}}}{d t}$ and $\frac{d H_{\mathrm{D}_{2} \mathrm{O}, \mathrm{ev}}}{d t}$ were clearly negligible: the $\mathrm{H}$ cell evaporation enthalpy never surpassed $\frac{3 \cdot 0.006 \text { grams } / \text { hour }}{3600 \mathrm{~s}} \cdot 45050 \frac{\text { joules }}{\text { mole }}=0.012$ watts and the contributions of the evaporation term to the heat from both cells partially canceled out. (The excess heat was in the order of $0.1-0.2$ watts). Nevertheless, a 0.012 watt enthalpy evaporation flat rate was subtracted from the excess heat.

The loading terms $\frac{d H_{\mathrm{PdH}_{\mathrm{x}}}}{d t}$ and $\frac{d H_{\mathrm{PdD}_{\mathrm{x}}}}{d t}$ were even more insignificant: still, a worst-case scenario was assumed in which the D cell fully loaded with deuterium and the $\mathrm{H}$ cell did not load at all with hydrogen. That gave a 0.0036 moles $\times$ $74500 \frac{\text { joules }}{\text { mole }}=270$ joule one-time loading enthalpy (or a $\frac{270 \mathrm{~J}}{7034 \cdot 60 \mathrm{~s}}=0.00064$ watt flat rate deduction averaged over all the 7034 steady-state minutes of electrolysis with the right polarity) that was subtracted from the final excess heat.

In the run of January 18, 2002, steady-state was reached 40' after switch-on. After $645^{\prime}$, the $\mathrm{H}$ cell was at an average (two thermocouple) temperature of $33.3^{\circ} \mathrm{C}$ and the D cell was at an average (two thermocouple) temperature of $35.2^{\circ} \mathrm{C}$. The $\mathrm{H}$ cell was at $3.70 \mathrm{~V}$ and the $\mathrm{D}$ cell was at $3.44 \mathrm{~V}$. The average power spent into electrolysis by the $\mathrm{H}$ cell, calculated from the loss rate of electrolyte, was 1.15 watts; while the average power spent into electrolysis by the $\mathrm{D}$ cell, from the loss rate of electrolyte, was 0.92 watts. At that moment in the run the ambient 
temperature $T_{\text {ambient }}$ was $20.8{ }^{\circ} \mathrm{C}$. Hence $T_{\mathrm{H}}-T_{\text {ambient }}=12.5{ }^{\circ} \mathrm{C}, T_{\mathrm{D}}-T_{\text {ambient }}=14.4$ ${ }^{\circ} \mathrm{C}$ and the excess heat at that moment was:

$\frac{d H_{\text {excess }}}{d t}>0.92$ watts $-3.44 V \cdot 0.75 A+[3.7 V \cdot 0.75 A-1.15$ watts $] \frac{14.4}{12.5}-0.012 \mathrm{~W}=$

$=0.20 \mathrm{watts}$

Things can be simplified even more. It can be further assumed that the $\mathrm{H}$ and $\mathrm{D}$ cells were at the same temperature at that moment, the rates of mass loss of electrolyte were the same in both cells, the puny evaporation correction for the $\mathrm{H}$ cell canceled out that of the D cell, and the even more puny loading correction for the $\mathrm{H}$ cell canceled out that of the $\mathrm{D}$ cell. With these simplifying assumptions the excess heat is just the difference in power input between the two cells at that moment: namely,

$$
(3.70 \mathrm{~V}-3.44 \mathrm{~V}) \cdot 0.75 A=0.195 \text { watts. }
$$

The thermocouples were found to have an error of $\pm 0.4{ }^{\circ} \mathrm{C}$, and therefore the relative error of the excess heat at that moment in the run was $11 \%$. Data had been acquired with Excel every 2'40', in this run. Adding the excess heat yield of each of these 2'40' intervals, the total excess heat for the 668' of steady state of this run was $8200 \pm 1400 \mathrm{~J}$. 
This is then the final result of the calculation. In all the minutes of steady-state in which the D cell ran with the right polarity, the excess heat produced by the D cell relative to the $\mathrm{H}$ cell was:

$$
\mathbf{5 5 7 2 7} \text { joules } \pm 14581 \text { joules }
$$

By contrast, the chemical enthalpy that would have been released by the D cathode if it got fully loaded with deuterium during all these minutes of electrolysis with the right polarity, was:

\section{0 joules}

The average excess heat of the $\mathrm{D}$ cell relative to the $\mathrm{H}$ cell during the steady-state portion (7034 minutes) of the 7857 minutes of electrolysis with the right polarity was then $0.13 \pm 0.03$ watt. The loading of the cathodes, the only readily imaginable chemical process that can go on, can produce over that time only 0.00064 watts.

The average power input of the $\mathrm{D}$ cell during the steady-state minutes of the right polarity was $2.33 \mathrm{~W}$. Hence the excess heat was $5.5 \pm 1.3 \%$ of the power input.

Table 11 summarizes the heat results for the 18 runs of the second experiment as estimated from cell mass losses. 
Table 11: HEAT SUMMARY OF THE SECOND EXPERIMENT (FROM CELL MASS

\section{LOSSES)}

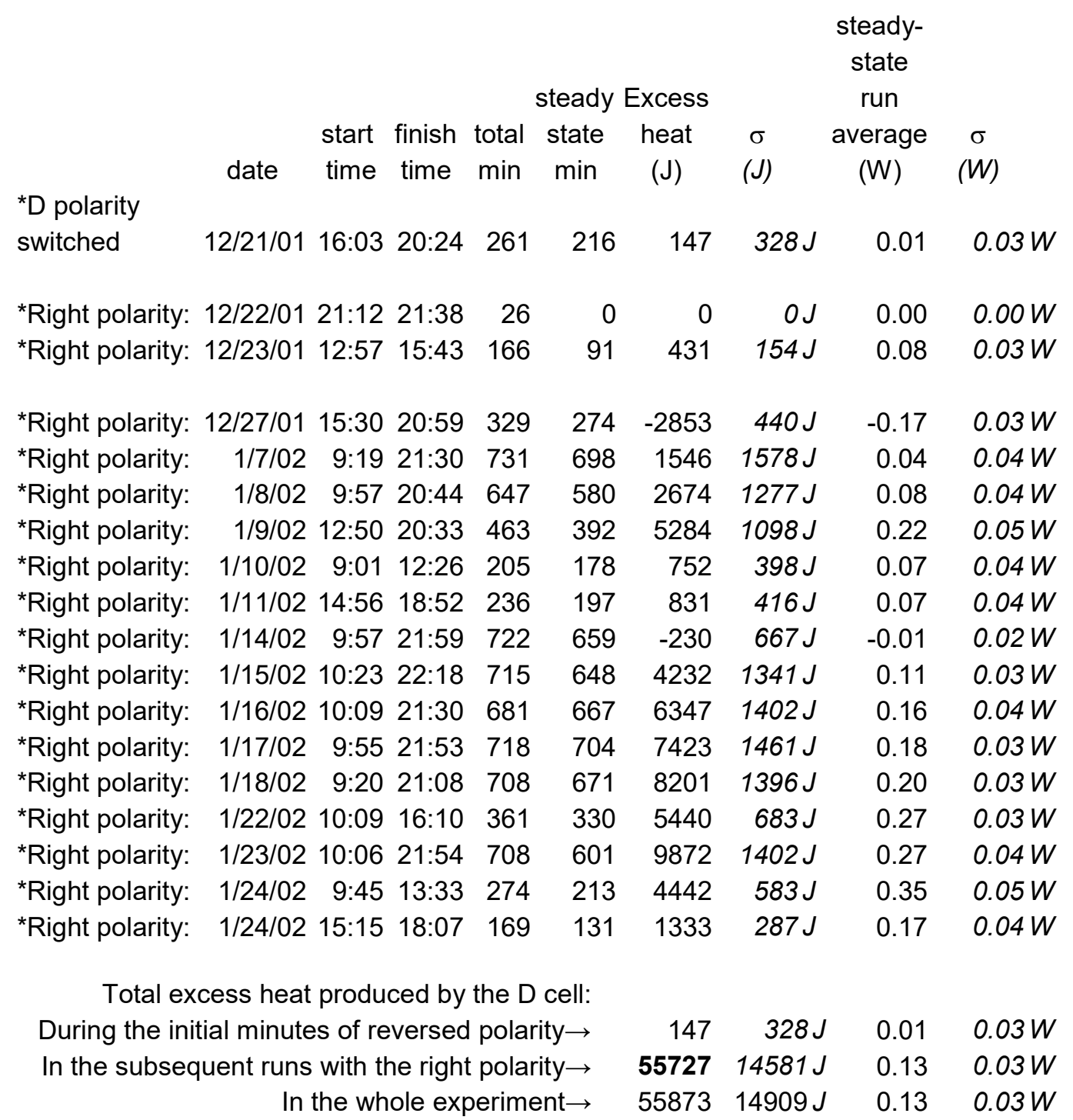


-Estimation based on direct Faradaic conversion of current:

Modeling the passive dragout of electrolyte due to evaporation in an experiment like this is very difficult, and hence it is more realistic to assume full Faraday efficiency and deduce the number of moles of light water (in the $\mathrm{H}$ cell) or heavy water (in the D cell) lost to electrolysis per unit time directly from the current.

It takes two electrons to split a water molecule, so $0.75 \mathrm{~A}$ of current translates to $\frac{0.75 \mathrm{~A}}{2 \cdot 1.602 \cdot 10^{-19} \mathrm{C} \cdot 6.023 \cdot 10^{23}}=3.88 \cdot 10^{-6} \mathrm{moles} / \mathrm{s}$ of water, or $1.11 \mathrm{~W}$ for $\frac{d H_{\mathrm{H}_{2} \mathrm{O}}}{d t}$ and $1.14 \mathrm{~W}$ for $\frac{d H_{\mathrm{D}_{2} \mathrm{O}}}{d t}$.

The formula for the excess heat then becomes simply:

$$
\begin{aligned}
& \frac{d H_{\text {excess }}}{d t}=-V_{\mathrm{D}} \cdot I+\frac{d H_{\mathrm{D}_{2} \mathrm{O}}}{d t}+\left[V_{\mathrm{H}} \cdot I-\frac{d H_{\mathrm{H}_{2} \mathrm{O}}}{d t}\right] \frac{T_{D}-T_{\text {ambient }}}{T_{\mathrm{H}}-T_{\text {ambient }}} \\
& \frac{d H_{\text {excess }}}{d t}=-V_{\mathrm{D}} \cdot I+1.14 \text { watt }+\left[V_{\mathrm{H}} \cdot I-1.11 \text { watt }\right] \frac{T_{D}-T_{\text {ambient }}}{T_{\mathrm{H}}-T_{\text {ambient }}}
\end{aligned}
$$

Table 12 lists the integrated excess heat for the 18 runs of the second experiment estimated by this direct current conversion approach.

The calculation gives much more heat in this way as expected, and in fact, according to this approach all runs produced excess heat, and, except for the one of January 14, 2002, in which the H cell was shorted for about an hour, the heat was above three standard deviations. 
Table 12: HEAT SUMMARY OF THE SECOND EXPERIMENT (FROM THE CURRENT)

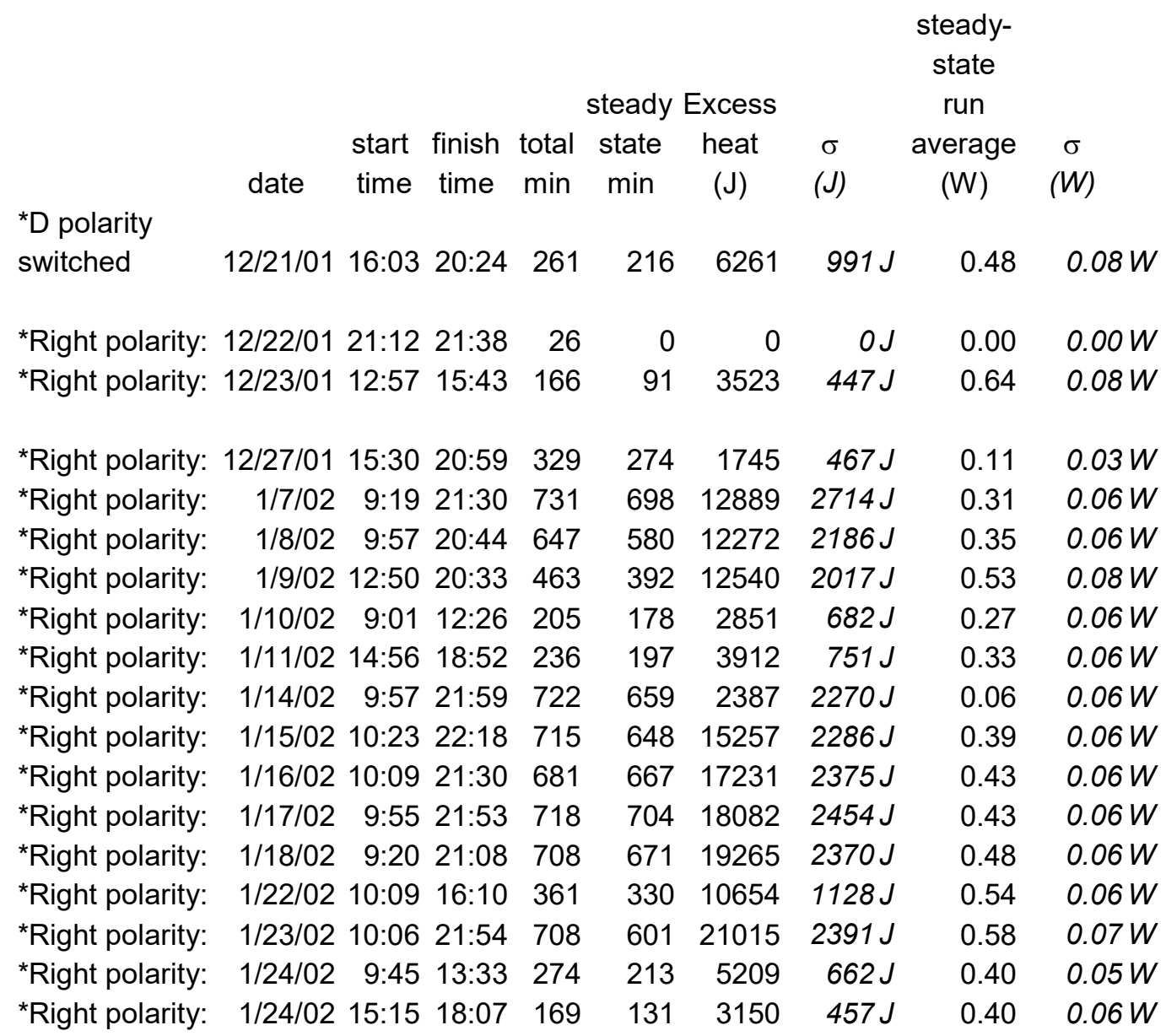

Total excess heat produced by the D cell:

$\begin{array}{rrrrr}\text { During the initial minutes of reversed polarity:-> } & 6261 & 991 \mathrm{~J} & 0.48 & 0.08 \mathrm{~W} \\ \text { In the subsequent runs with the right polarity:-> } & 161982 & 14581 \mathrm{~J} & 0.38 & 0.06 \mathrm{~W} \\ \text { In the whole experiment:-> } & 168243 & 26648 \mathrm{~J} & 0.39 & 0.06 \mathrm{~W}\end{array}$

The average excess heat calculated by this Faradaic method was then $0.38 \pm 0.06 \mathrm{~W}$ or $16.3 \pm 2.6 \%$ of the power input of the D cell. 


\section{Chemical explanations:}

There are some possible heat-releasing chemical mechanisms that might have taken place in this experiment, in addition to the loading of palladium, and they will be examined to ascertain if they could account for some of the excess heat.

-Sulfuric acid is well known to release large amounts of heat when dissolved in water:

$\mathrm{H}_{2} \mathrm{SO}_{4}(l)+\mathrm{nH}_{2} \mathrm{O}(l) \rightarrow \mathrm{H}_{2} \mathrm{SO}_{4} \cdot \mathrm{nH}_{2} \mathrm{O}(a q)+\Delta H_{\text {dilution, } \mathrm{H}_{2} \mathrm{SO}_{4}(T)(x)}$

But this heat of dilution dissipates right after mixing, and the mixing of the sulfuric acid was done days before the start of the experiment.

Nevertheless, as the concentration of sulfuric acid gradually diminished into the experiment, the electrolyte must have demanded back some extra heat that the electrodes had to generate (in addition to the heat expended into evaporation), and this happened at a different rate in the $\mathrm{H}$ cell than in the $\mathrm{D}$ cell. It might be logical to ask if this might be a background source of excess heat.

The enthalpy of dilution of sulfuric acid has been widely studied due to its tremendous industrial importance, and at $20{ }^{\circ} \mathrm{C}$ can be summarized with the formula (Sander et al., 1984):

$$
\Delta H_{\text {dilution, } \mathrm{H}_{2} \mathrm{SO}_{4}\left(20^{\circ} \mathrm{C}\right)(x)}=-\left[-447.65 x^{3}-273.18 x^{2}-25.312 x+725.23\right] \cdot 98 \frac{\mathrm{J}}{\text { mole }}
$$


with $x$ the unit concentration of sulfuric acid by weight. In the $\mathrm{H}$ cell the initial sulfuric acid concentration in the electrolyte at the beginning of the experiment was 4.2\%: at the end of the experiment the concentration had thickened to $15.9 \%$. This means that as a result of dehydration the $\mathrm{H}$ cell electrolyte absorbed $\Delta H_{\text {dilution, } \mathrm{H}_{2} \mathrm{SO}_{4}\left(20^{\circ} \mathrm{C}\right)(0.042)}-\Delta H_{\text {dilution, } \mathrm{H}_{2} \mathrm{SO}_{4}\left(20^{\circ} \mathrm{C}\right)(0.159)}=1687.9 \mathrm{~J}-1667.2 \mathrm{~J}=20.6$ joules in the course of the experiment that its electrodes had to produce, in addition to the excess heat that was already being generated (which in this model is assumed to be zero). In the D cell, even assuming that only 13.95 grams of sulfuric acid had been mixed in the original electrolyte, the initial sulfuric acid concentration was no less than $22.47 \%$ and the final sulfuric acid concentration was no less than $46.31 \%$. This means that the $\mathrm{D}$ cell absorbed $\Delta H_{\text {dilution, } \mathrm{H}_{2} \mathrm{SO}_{4}\left(20{ }^{\circ} \mathrm{C}\right)(0.2247)}-\Delta H_{\text {dilution, } \mathrm{H}_{2} \mathrm{SO}_{4}(20}$ $\left.{ }^{o} C\right)(0.4631)=9771.1 \mathrm{~J}-8515.7 \mathrm{~J}=1255.3$ joules in the course of the experiment due to dehydration that its electrodes had to produce, in addition to whatever absolute excess heat was already being generated in this cell. That is to say, in order to compensate for the progressive dehydration of the sulfuric acid in its electrolyte, the $\mathrm{D}$ cell generated, in addition to whatever absolute excess heat was already there from any other cause, more than sixty times what the $\mathrm{H}$ cell generated in addition to its own absolute excess heat from other sources (which is zero in this model). The D cell was far from operating at sixty times the temperature of the $\mathrm{H}$ cell, however. Far from accounting for some of the relative excess heat that was observed in the D cell, the progressive dilution of sulfuric acid only aggrandizes (if by a small amount, $\sim 2 \%$ ), the amount of excess heat that has to be explained. 
-Other chemical compounds. It is highly unlikely that any chemical reactions took place other than the loading of the cathodes, but even if they did they would have taken place in both cells and hence their enthalpy releases would have canceled out in the final heat analysis. The only exception was the first run when the polarity of the D cell was reversed, some of the palladium dissolved, and as a result the black powdery substance, most likely PdS or PdO, was formed. PdS has an enthalpy of formation $\Delta H_{f}^{o}$ of $-70,710 \frac{J}{m o l e}$ and $\mathrm{PdO}$ has an $\Delta H_{f}^{o}$ of $-115,478$ $\frac{J}{\text { mole }}$ (Barin, 1989). Even if all the 0.0036 moles of the D cell Pd cathode had combined with oxygen, that would still only account for $\sim 120000 \frac{\mathrm{J}}{\mathrm{mole}} \cdot 0.0036$ moles $=440$ joules of excess heat.

Some stains were formed on both sides of the $\mathrm{H}$ cell anode which under EDS revealed concentrations of oxygen and sulfur higher than in surrounding areas. It is a possibility that these stains were platinum sulfates or sulfides. The inside of the D cell anode, which formed a little roll, could not be seen clearly, but the outside was interestingly free of these stains.

Nevertheless, the mass of the anodes was the same before as after the experiment. The accuracy of the balance was \pm 0.0005 grams. Even a difference of 0.01 grams translates only to $\sim 0.00005$ moles of platinum, or 35 joules of enthalpy. 
-The Joule-Thomson effect has occasionally been cited as an artifact that could explain away some of the excess heat in experiments like this (Hoffman, 1995). The adiabatic expansion of hydrogen, in fact, is a major heat producer above -80 ${ }^{\circ} \mathrm{C}$, and its sudden occurrence is more than a possibility when any of the pores in the palladium cathode breaks and the hydrogen that had been bonded inside puffs out. And for a given loading ratio in the palladium, the equilibrium pressure of $\mathrm{D}_{2}$ is higher than the $\mathrm{H}_{2}$ pressure. But there is an upper limit to the power that can be relinquished by the Joule-Thomson heating effect, not only because pores in palladium are rather scarce, but also because pores within the palladium cannot be pressurized to more than $20 \%$ of the shear modulus. For the effect to carry on past that point, the pores in the palladium would have to grow faster than the pressurization. Pressurization above $20 \%$ of the shear modulus is actually possible but it requires that pores had previously nucleated in the palladium.

Also, and unless pores are previously nucleated in the palladium, the JouleThomson effect requires that enough internal pressure be previously built inside the palladium cathode (such as by electrolysis), so that defects and cracks may appear. Hence, and unless the palladium already contained nucleated pores, while electrolysis is unfolding and the pressure is building up, cooling, not heating, is what occurs. As a result the Joule-Thomson effect cannot truly be invoked to explain the excess heat in an experiment like this, but it certainly can play a role in other "heat after death" reports when heat was observed in similar experiments after the current was switched off (Hoffman, 1995). 
The conclusion is that, while chemical reactions may have played a minor role in this experiment, the magnitude of the enthalpies they released falls at least an order of magnitude short of explaining the total heat that was produced.

Even if one subtracts a full $3 \sigma$ from the final excess heat estimate by cell mass losses, and subsequently one deducts the maximum enthalpy that could have been relinquished by all the conceivable chemical processes that might have taken place in this experiment other than the loading of the cathodes, which is definitely no more than 700 joules; the net result, 11284 joules, is still more than ten times the maximum total enthalpy that could have been produced chemically in this experiment, 970 joules. That is to say, the excess heat that the $\mathrm{D}$ cell produced compared to the $\mathrm{H}$ cell is more than eleven times the heat that can be explained by all the chemical processes that could have taken place inside the D cell.

If the excess heat is calculated instead assuming a full Faradaic efficiency in the electrolysis, the excess heat minus three standard deviations and minus the total chemical enthalpy that could have been released in this experiment is over two orders of magnitude larger than this total chemical enthalpy. The excess heat minus ten standard deviations and minus the total chemical enthalpy release is still over ten times larger than this total chemical enthalpy release, adopting this Faradaic efficiency approach for the heat calculation.

Or, to put it in a more impacting form: 
970 joules is the maximum excess heat that chemical reactions can account for in this experiment.

But still, to account for all the excess heat that was produced in this experiment,... .. at least another ......

\section{4 joules remain to be explained.}

Additionally, there were the new elements $\mathrm{Ag}$ and $\mathrm{Cd}$ found on the cathodes in the EDS characterization, and which mere chemical or mechanical mechanisms cannot account for. Other explanations must be sought.

\section{Nuclear explanations:}

There is a simple explanation that would account for all the excess heat that was observed in these two experiments, as well as for the presence of the new elements, and this is that nuclear reactions somehow took place.

Nuclear reactions happen frequently at room temperature (Hoffman, 1995; Jones et al., 1989): To induce them, all it takes is an energetic charged particle that may be traveling through the atmosphere, such as the ones that are constantly being created by the collision of cosmic rays on the upper stratospheric layers of the Earth (Hoffman, 1995), or a low-energy neutral ambient particle such as the neutron (Kozima, 1998). 
It is well known that a thermonuclear reaction cannot happen at room temperature: the energy necessary to initiate it is many orders of magnitude too high (Rosen, 1989; Halley and Valles, 1990). It is not necessary to invoke one however to explain the heat released in these two experiments, or in any of the countless similar ones in electrolytic, gas or plasma discharge conditions that have since 1989 detected excess heat, new elements and tritium/helium-4 in levels not attributable to background (Kozima et al., 1998; Kozima, 2000).

A plausible mechanism that would explain the excess heat and the new elements has been suggested by Kozima, and it involves the palladium cathode trapping some thermal neutrons from the air (Kozima, 1998). The various palladium nuclides present in the cathode then would absorb some of these thermal neutrons, forming unstable palladium isotopes which would subsequently beta-decay to silver and, in the instances when a double beta decay route might be feasible, to cadmium. The de-excitation energy would be relinquished by the nuclei into the lattice as phonons, however, instead of the hard gamma rays that are emitted by the thermonuclear reactions that happen in the interior of the stars or in the few successful seconds of breakeven that have so far been achieved in tokamaks. The mechanism of this de-excitation is not clear at present but Kozima has suggested a pathway that would involve interactions with neutron drops and with high-density neutrons surrounding the decaying nuclides (Kozima, 2000). It might even be possible for the neutrons of the cathode to cluster into macroscopic Bose-Einstein condensates, similar to what can be found inside a neutron star (Baym et al., 1971; 
Negele and Vautherin, 1973; Crowley, 1989; Fisher, 1998). The only role of electrolysis is then to aggrandize, via the injection of hydrogen or deuterium into the Pd solid state lattice, the cross section that the palladium nuclides present in the lattice have towards the new trapped thermal neutron ensemble, making the rates of neutron-induced transmutation to silver (and subsequently to cadmium) rise from the levels that would naturally occur in a passively-sitting piece of palladium.

$$
\begin{array}{ll}
n+{ }_{46}^{108} \mathrm{Pd} \rightarrow{ }_{46}^{109} \mathrm{Pd}^{*} \rightarrow{ }_{46}^{109} \mathrm{Pd}+6.15 \mathrm{MeV} \text { in phonons } & \text { (D and H Pd cathodes) } \\
{ }_{46}^{109} \mathrm{Pd} \rightarrow{ }_{47}^{109} \mathrm{Ag}+e^{-}+\bar{v}_{\mathrm{e}}+1.166 \mathrm{MeV} \text { in phonons } & \text { (D and H Pd cathodes) } \\
n+{ }_{46}^{106} \mathrm{Pd} \rightarrow{ }_{46}^{107} \mathrm{Pd} * \rightarrow{ }_{46}^{107} \mathrm{Pd}+\text { phonons } & \text { (D and H Pd cathodes) } \\
{ }_{46}^{107} \mathrm{Pd} \rightarrow{ }_{47}^{107} \mathrm{Ag}+e^{-}+\bar{v}_{\mathrm{e}}+\text { phonons } & \\
n+{ }_{47}^{107} \mathrm{Ag} \rightarrow{ }_{47}^{108} \mathrm{Ag} \rightarrow{ }_{48}^{108} \mathrm{Cd}+e^{-}+\bar{v}_{\mathrm{e}}+\text { phonons } & \text { (D and H Pd cathodes) }
\end{array}
$$

In free space, the neutron-absorption of ${ }_{46}^{108} \mathrm{Pd}$, which has an abundance of $26.8 \%$ in natural palladium, delivers a gamma ray of $6.2 \mathrm{MeV}$, and subsequently another gamma ray of $1.166 \mathrm{MeV}$ as ${ }_{46}^{108} \mathrm{Pd}$ beta-decays to ${ }_{47}^{109} \mathrm{Ag}$, totaling a release of energy of $7.31 \mathrm{MeV}$. Assuming that the mechanism suggested by Kozima works and that this energy is released as heat instead of as radiation, the transmutation of only $\sim 4 \%$ of the ${ }_{46}^{108} \mathrm{Pd}$ nuclides up to a depth of $\sim 1 \mu \mathrm{m}$ on the cathodes would then release $\sim 0.04 \cdot 0.268 \cdot 7 \cdot 10^{22} \mathrm{~cm}^{-3} \cdot 0.0002 \mathrm{~cm} \cdot 0.5 \cdot \mathrm{cm} \cdot 2 \mathrm{~cm} \cdot 7.3 \cdot 1.6 \cdot 10^{-13}$ 
$J=170,000 \mathrm{~J}$. If this transmutation were to happen $\sim 30 \%$ more abundantly on the $\mathrm{D}$ cell cathode than on the $\mathrm{H}$, the excess heat of $\sim 60,000 \mathrm{~J}$ that was deduced from the cell mass losses in the second experiment would be explained. To explain the higher value of $\sim 160,000 \mathrm{~J}$ for the excess heat that was deduced using the full Faradaic efficiency approach, 4\% more ${ }_{46}^{108} \mathrm{Pd}$ nuclides on the $\mathrm{D}$ cathode than on the $\mathrm{H}$ would have to trap neutrons and undergo transmutation to ${ }_{47}^{109} \mathrm{Ag}$ up to this depth of $\sim 1 \mu \mathrm{m}$. The energy released by the transmutation of the other Pd isotope, must also be taken into account, as well as the subsequent follow-on transmutation of the resulting ${ }_{47}^{107} \mathrm{Ag}$ to ${ }_{48}^{108} \mathrm{Cd}$, which would according to the results of the EDS characterization happen much more preferentially on the $\mathrm{H}$ cell cathode than on the D cell cathode. Nevertheless, these figures clearly indicate that the observed levels of transmutation on the cathodes following electrolysis are consistent with the magnitude of the excess heat that was observed if the trapped-thermal-neutron model is adopted.

Deuterons also are expected to absorb neutrons, transmuting into the unstable nucleus of tritium, which then decays naturally to helium-3. Hence the occurrence of this process among the deuterons in the D cell cathode is another avenue through which the excess heat can be accounted for. Protons can in principle absorb neutrons as well, but their cross section is too small, and so the analogous process among the protons in the solid-state lattice of the $\mathrm{H}$ cell cathode can be neglected:

$n+{ }_{1}^{2} \mathrm{D} \rightarrow{ }_{1}^{3} \mathrm{H}+$ phonons

(D Pd cathode only) 
${ }_{1}^{3} \mathrm{H} \rightarrow{ }_{1}^{3} \mathrm{He}+e^{-}+\bar{v}_{\mathrm{e}}+$ phonons

(D Pd cathode only)

In free space, the reaction $n+{ }_{1}^{2} \mathrm{D} \rightarrow{ }_{1}^{3} \mathrm{H}$ delivers a $\gamma$ photon of $6.25 \mathrm{MeV}$. In the solid-state environment of palladium, however, the energy would be released as a phonon instead of as a photon, and hence would be detected as pure heat (Kozima et al., 1998; Kozima, 2000; Hagelstein, 2000). It would only take $\frac{0.13 \mathrm{~J} / \mathrm{s}}{6.25 \cdot 1.6 \cdot 10^{-13} \mathrm{~J}}=1.3 \cdot 10^{11}$ events of this sort per second to account for the value $0.13 \mathrm{~W}$ of the excess heat that was estimated from the cell mass losses. Only $5.6 \cdot 10^{16}$ deuterons would have had to undergo a neutron absorption of this sort to produce all the heat that was observed in the 7034 steady-state minutes of the experiment with the right polarity. If the D cell cathode got fully loaded, there would be 0.0036 moles $\cdot 6.02 \cdot 10^{23}=2.2 \cdot 10^{21}$ deuterons available in the cathode: i.e., the absorption of a neutron by only $0.0025 \%$ of the deuterons present in the cathode would be sufficient to account for the excess heat.

It is also plausible that the presence of deuterium in the solid-state lattice of the D cell cathode blocks off some of the neutrons that would have been absorbed otherwise by the palladium and silver nuclides, explaining why the double transmutation to cadmium occurred in the $\mathrm{H}$ cell cathode but was virtually absent in the $\mathrm{D}$ cell cathode. 


\section{Related results that have been reported by other researchers:}

In the first experiment that was performed at Portland State University (from now on referred to as the PSU-1 experiment), the heat results were not of good quality. The observed excess heat in the second experiment that was performed at Portland State University (from now on referred to as the PSU-2 experiment) was $0.13 \pm 0.03$ $\mathrm{W}, 0.38 \pm 0.06 \mathrm{~W}$ if the heat was calculated by the Faradaic approach. This excess heat is in line with what has been reported by other researchers. Given that the portion of the cathode of the heavy water submerged in the electrolyte of this PSU2 experiment had an area of $\sim 1 \mathrm{~cm}^{2}$ and a volume of $\sim 0.03 \mathrm{~cm}^{3}$ (corresponding to $\sim 0.4$ grams of Pd metal), the observed heat $\left(0.13-0.38 \mathrm{~W} / \mathrm{cm}^{2}, 3-12 \mathrm{~W} / \mathrm{cm}^{3}, 0.3-1\right.$ $\mathrm{W} / \mathrm{g}, 5-16 \%$ of the power input) is consistent with many experimental results in the field:

-Celani et al. (1994) has reported $12.5 \%$ of the power input with a highpower pulsed current. Celani's Pd cathodes measured $1 \mathrm{~mm} \times 25 \mathrm{~mm} \times 25$ mm. The Pd was TANAKA K.K., had a very high hardness value, had been cold-worked, and had reached its high hardness via doping (2780 ppm of impurities had been deliberately placed in the melting preparation of this material). As in the PSU-2 experiment, the anode in Celani's tests was Pt (though of a wire net kind), and was placed $\sim 1 \mathrm{~cm}$ from the cathode. Celani's electrolyte was LiOD $0.3 \mathrm{M}$ in $\mathrm{D}_{2} \mathrm{O}$. The blank tests in Celani's experiment used an Au plate instead of Pd. During the tests, the pulse peak 
current was $60 \mathrm{~A}$ and the width of the pulse was $0.5 \mu \mathrm{s}$. The pulse repetition rate was initially set at $5 \mathrm{KHz}(0.164 \mathrm{~A}$ mean current). It was at this pulse repetition rate of $5 \mathrm{KHz}$ that the $12.5 \%$ excess power of the Pd sheet over the Au sheet was measured. The pulse frequency range was varied from 5 to $20 \mathrm{KHz}$, with no detected effect on the excess heat. At the $2-3 \mathrm{~W}$ input power range of the PSU-2 experiment, Celani's excess heat was $0.25-0.37$ $\mathrm{W}, 0.04-0.06 \mathrm{~W} / \mathrm{cm}^{2}, 0.4-0.6 \mathrm{~W} / \mathrm{cm}^{3}$ or $0.03-0.05 \mathrm{~W} / \mathrm{g}$. It is significant that two other cold-worked Pd sheets of the same dimensions (one of them of the same TANAKA K.K. material) produced no excess heat: the nonexcess-heat producing Pd sheets in Celani's experiment, however, received their 16 A-peak-value, $5 \mathrm{KHz}$ pulse for only $500 \mathrm{~ns}$ (64 mA mean current), as opposed to the $1800 \mathrm{~ns}$ of the excess-heat-producing sheet $(164 \mathrm{~mA}$ mean current).

-Miles and Bush (1994) have reported 0.1-2.5 W/cm 3 , 0.008-0.21 W/g and 0.03-0.26 W/ $\mathrm{cm}^{2}$ (absolute excess power 0.03-0.06 W) for several Pd cathodes under electrolysis in (initially) $0.1 \mathrm{M} \mathrm{LiOD}+\mathrm{D}_{2} \mathrm{O}$. The main finding by Miles and Bush, however, was that the ${ }^{4} \mathrm{He}$ concentrations after electrolysis would be correlated with the measured excess heat if somehow the direct $d$-d nuclear fusion reaction occurred and the $23.8 \mathrm{MeV}$ of this fusion reaction were released as pure heat. It is well known that ${ }^{2} D\left({ }^{2} D, \gamma\right){ }^{4} \mathrm{He}$, which is the nuclear reaction invoked by many workers in 
the field to explain some experimental results, needs many millions of ${ }^{\circ} \mathrm{C}$ to be initiated at appreciable rates, and then delivers its $23.8 \mathrm{MeV}$ of energy as a high-energy gamma ray. The possibility that such a reaction could be induced at room temperature and could be made to deliver its energy in heat form instead of as a gamma ray is still not considered seriously by most physicists despite growing evidence that in a solid state environment like the lattice structure of palladium such a modification of ${ }^{2} D\left({ }^{2} D, \gamma\right){ }^{4} \mathrm{He}$ could actually occur. The lack of other explanations (chemical, artifactbased) for the excess heat and the sometimes correlated ${ }^{4} \mathrm{He}$ increased levels after experiments like those of Miles and Bush is the primary reason why the solid-state-screened, gamma-ray-suppressed $d-d$ nuclear fusion hypothesis is taken into consideration by some (Hagelstein, 2000; Chubb and Chubb, 2000), although Kozima's conventional, trapped-neutron-based approach might provide an alternative route to understand the phenomenon (Kozima et al., 1998; Kozima, 2000).

-Ota et al. (1994) have reported excess heat in many runs using Pd cathodes as well as Pd-Ag alloys of $90 \% \mathrm{Pd}-10 \% \mathrm{Ag}$ and $75 \% \mathrm{Pd}-25 \% \mathrm{Ag}$ composition. The electrolyte used in all runs was LiOD in $\mathrm{D}_{2} \mathrm{O} .1 \mathrm{M}$ LiOD was employed in most cases but heat was also reported from 0.1 M LiOD in one instance. In one run, with a $\mathrm{Pd}_{0.9} \mathrm{Ag}_{0.1}$ rod-shaped cathode of $5 \mathrm{~mm}$ diameter and $1 \mathrm{~cm}$ length, a 220 hour long heat burst of $3.6 \cdot 10^{6} \mathrm{~J}$ was 
reported (4.5 W average). That corresponded to $9 \mathrm{~W} / \mathrm{cm}^{2}, 22.7 \mathrm{~W} / \mathrm{cm}^{3}$ or $\sim 1.9 \mathrm{~W}$ per gram of alloy, which, bearing in mind that in this run the input power was $10 \mathrm{~W}$, is in the same range as the excess heat observed in the 2.33-W-power-input PSU-2 experiment. The current density in this run of Ota et al. varied between 0.25 and $0.89 \mathrm{~A} / \mathrm{cm}^{2}$, similar to the $0.75 / \mathrm{cm}^{2}$ in the PSU-2 experiment. It is interesting that in this particular run by Ota $e t$ al., the cathode had been mechanically treated (six notches of $0.2 \mathrm{~mm}$ width and $2 \mathrm{~mm}$ depth had been cut into it), compressed and quenched at $750{ }^{\circ} \mathrm{C}$. The control cells used for calibration in the experiment of Ota et al. had Pt wires for both the anode and the cathode and employed a $1 \mathrm{M} \mathrm{LiOH} \mathrm{H}_{2} \mathrm{O}$ solution. The average excess heat in the 220 hour burst observed by Ota $e t$ al. was $6.5 \%$ of the input power; the peak was $13 \%$. Pure Pd cathodes also gave excess heat in other runs performed by Ota et al., with peak values of $3 \%, 2 \%, 9 \%, 3 \%, 3 \%$ and a solitary record-setting run that gave a $74 \%$ peak excess power. Two runs with pure Pd cathodes, however, failed to produce excess heat $(-3 \%$ and $-2 \%$ were the values of the average excess power): both were performed in the low concentration, $0.1 \mathrm{M} \mathrm{LiOD}$ electrolyte. By contrast, the initial $\mathrm{H}_{2} \mathrm{SO}_{4}$ concentration in the $\mathrm{D}_{2} \mathrm{O}$ cell of the PSU-2 experiment was over $2.6 \mathrm{M}$.

The main reference, however, is Keefe's forerunner two experiments at PSU, which employed almost identical materials and methods. Keefe (1990) reports for his first experiment (Pd cathodes: $0.03 \mathrm{~mm} \times 5 \mathrm{~mm} \times 3 \mathrm{~cm}$; Pt anodes $0.03 \mathrm{~mm} \times 2 \mathrm{~cm} \times 2$ 
$\mathrm{cm})$ that for the last 15 hours of electrolysis, the temperature of the D cell exceeded the temperature of the $\mathrm{H}$ cell by an average of $1.1{ }^{\circ} \mathrm{C}$ even though $3 \%$ less power was going into the D cell. Given the fact that Keefe's cells had a recombination catalyst, that corresponded to $0.23 \mathrm{~W}$ excess heat (for a $1.8 \mathrm{~W}$ input power). In the initial hours of Keefe's first experiment, though, the H cell was slightly warmer, and so the total excess heat averaged for the whole continuous 2700 minutes of Keefe's first experiment was basically zero. In Keefe's second experiment, which lasted a total of continuous 10080 minutes, the average excess heat was $0.2 \mathrm{~W}$ with $2.3 \mathrm{~W}$ power input ( $9 \%$ excess power), and the last 96 hours maintained $0.34 \mathrm{~W}$. In this second experiment of Keefe, the Pd cathodes measured $0.35 \mathrm{~mm} \times 2.5 \mathrm{~mm} \times 4$ $\mathrm{cm}$ and had $1 \mathrm{~cm}^{2}$ exposed to the electrolyte, so $0.2 \mathrm{~W}$ corresponded to $0.2 \mathrm{~W} / \mathrm{cm}^{2}$, 5.7 W/cm ${ }^{3}$, or $0.5 \mathrm{~W}$ per gram of exposed Pd, all matching the results of the PSU-2 experiment. The relatively long incubation period required for excess heat to begin showing up in Keefe's two experiments (35 hours for his first experiment and 24 hours for his second) is typical in this kind of $\mathrm{Pd}-\mathrm{D}_{2} \mathrm{O}$-based electrolytic experiment (Storms, 1991).

The cathodes of Keefe's second experiment were found to contain $\mathrm{Au}$ after electrolysis (Noble, 1994; Noble et al. 1995) on localized microscopic plateaus that had appeared facing the anode (on two spots of Keefe's light water cathode the Xray peaks were almost as high as those of $\mathrm{Pd}$ itself). No $\mathrm{Ag}$ or $\mathrm{Cd}$ were found (though in one of the spectra from the light water cathode the height of a $\mathrm{Pd} \mathrm{L}_{\beta}$ 
peak relative to its corresponding $\mathrm{Pd} \mathrm{L}_{\alpha}$ peak was compatible with a tenuous trace of $\mathrm{Ag}$ ). There is no clear explanation for this.

After Nicholas (1992) subjected Keefe's second experiment cathodes to extra electrolysis time, totaling about 400 hours, Noble (1994) found gold on them, and Dash, Noble and Diman (1994) confirmed that more gold was present on Keefe's Pd heavy water cathode than on his light water cathode. In another $\mathrm{D}_{2} \mathrm{O}+\mathrm{H}_{2} \mathrm{SO}_{4}$ versus $\mathrm{H}_{2} \mathrm{O}+\mathrm{H}_{2} \mathrm{SO}_{4}$ experiment using $0.03 \mathrm{~mm} \mathrm{Pt}$ foil anodes, $0.055 \mathrm{~mm}$ Pd foil cathodes and a $0.7 \mathrm{~A} / \mathrm{cm}^{2}$ current density, $\mathrm{Ag}$ was found at surface eruptions close to the edges of the cathodes where some form of melting seemingly occurred, but not elsewhere, and Au was not found (Dash, Noble and Diman, 1994). In this subsequent experiment, the $\mathrm{D}_{2} \mathrm{O}+\mathrm{H}_{2} \mathrm{SO}_{4}$ cell again produced $\sim 0.1 \mathrm{~W}$ excess heat relative to the $\mathrm{H}_{2} \mathrm{O}+\mathrm{H}_{2} \mathrm{SO}_{4}$ cell.

Recently, Szpak et al. (2002) have electrodeposited palladium deuteride on copper in an open cell. Excess heat, X-rays and tritium levels ten times above background have been detected. A palladium-boron alloy seemed to be highly successful at reproducing sustained heat generation, as Miles also studied. According to the work of Szpak et al. (1991, 2002), pulverized palladium (which is what was accidentally produced in the first run of the PSU-2 experiment when the D cell was hooked up with the wrong polarity by mistake) facilitates reliable excess heat production. This might explain why the onset of excess heat was so quick in the PSU-2 experiment and the heat was of such repeatable high-quality run after run, compared to the 
PSU-1 experiment, in which the polarity of the D cell was not reversed for the first minutes.

Substantial work remains to be done until the full mechanism that produces excess heat and new elements in experiments like this, if this general mechanism is indeed the same for all of these experiments, may be understood, though Kozima's trapped-neutron-catalyzed nuclear transmutation model (Kozima et al., 1998; Kozima, 2000) is clearly a very promising start.

Storms (1991), in summarizing the status of the field, detects an apparent overall pattern in all the experiments that have been successful at detecting excess heat so far: the power yield density seems to be proportional to the applied current density once this power density exceeds a certain minimum onset value of $\sim 0.1 \mathrm{~A} / \mathrm{cm}^{2}$ (the current density in the PSU-2 experiment was $\sim 0.7 \mathrm{~A} / \mathrm{cm}^{2}$ ).

Nevertheless, Warner at Portland State University, who has conducted many experiments with $\mathrm{D}_{2} \mathrm{O}+\mathrm{H}_{2} \mathrm{SO}_{4}$ electrolytic systems using titanium cathodes and platinum anodes and has observed excess heat and new elements in a good fraction of them (Warner, 1998; Warner, 2001), suspects that there might be special current densities for which the power yield of the cell reaches special maximums as if some kind of resonance were involved (Warner, in private communication). 


\section{SUMMARY AND CONCLUSIONS:}

Two experiments have been performed. In each experiment, two cells were connected in series and thus received the same current of $0.75 \mathrm{~A}$. The two cells were identical except for the fact that the heavy water cell used heavy water instead of light water in the electrolyte. Both cells in each experiment employed $\mathrm{Pd}$ cathodes (with dimensions of $22 \times 3 \times 0.35 \mathrm{~mm}$ in the first experiment and $22 \times 5 \times$ $0.27 \mathrm{~mm}$ in the second), Pt anodes (with dimensions of $25 \times 12 \times 0.1 \mathrm{~mm}$ ), and some amount of $\mathrm{H}_{2} \mathrm{SO}_{4}$ in the solution to improve electrical conductivity.

The new software to measure excess heat had not arrived in the first experiment but the indication was that the light water cell was slightly warmer despite receiving slightly less power. In this first experiment, the cathode of the light water cell finished slightly more bent than the cathode of the heavy water cell, which suggests that more heat-releasing microscopic activity took place in the former one. Small amounts of silver were found on both cathodes after electrolysis. In a small cranny on the heavy water cell cathode after electrolysis, concentrations of Ag surpassing $20 \%$ that of $\mathrm{Pd}$ were found.

The second experiment was conducted as soon as the new software to measure heat had arrived, and the heavy water cell produced an excess heat relative to the light water cell that was too large by at least an order of magnitude to be explainable by chemical reactions or mechanical artifacts. Excess heat was observed in 14 out of 17 runs. In this second experiment, the light water cathode 
finished very straight. Still, small and variable amounts of Cd (3-4\%) were found over the surface of this light water cathode. This $\mathrm{Cd}$ could not be attributed to contamination. The heavy water cell cathode finished severely arched $\left(\sim 30^{\circ}\right)$, the convex side facing the anode, and thickly covered in a deposit of black powdery substance which was most likely PdS and which had formed by accident in the first day of this experiment when the heavy water cell had been hooked up with the wrong polarity. SEM analysis confirmed that S was present in this black powdery coating. On this heavy water cell cathode, there was no Cd but Ag was present in $2-5 \%$ concentration. These levels could not be attributed to background and the Ag peaks in the X-ray spectrum were unmistakable and statistically well above background. In a localized nook, the concentration of $\mathrm{Ag}$ surpassed $20 \%$ that of $\mathrm{Pd}$. The most likely explanation is nuclear transmutation.

Other researchers have made many similar findings (Keefe, 1990; Storms, 1991; McKubre et al., 1994; Noble, 1994; Dash et al., 1994; Arata and Zhang, 1994; Ota et al., 1994). Various theories have been advanced to explain how nuclear transmutations in solid-state environments could relinquish energy as direct heat instead of as the usual high-energy radioactive byproducts (Kozima, 2000; Hagelstein, 2000), but the reality is that the mechanism that generates all the excess heat remains largely unknown. As any other avenue of research with promise of leading to a novel and clean energy source, the study of these phenomena should be continued (Riley and McLaughlin, 2001). 


\section{REFERENCES:}

Arata, Y. and Zhang, Y-C., 1994. A new energy caused by "spillover-deuterium': Proc. Japan Acad. Ser. B, v. 66, p. 1; Arata, Y. and Zhang, Y-C., 1992. "Cold" fusion in a complex cathode, in Proc. Third International Conference on Cold Fusion, October 21-25, 1992, Nagoya, Japan, Frontiers of Cold Fusion, (H. Ikegami, ed.): Tokyo, Japan, Universal Academy Press, Inc., p. 441.

Azzarone, D., Fontana, F., Garbelli, D., 2000. Hydrogen/deuterium loading in thin palladium wires, in Proc. Eighth International Conference on Cold Fusion, Lerici (La Spezia), Italy 21-26 May 2000, F. Scaramuzzi, ed., Società Italiana di Fisica.

Bailar, J.C., Emeleus, H.J., Nyholm, R., 1973. Comprehensive inorganic chemistry, (Pergamon Press, Oxford).

Barin, I., 1989. Thermochemical Data of Pure Substances, Part II: VCH Verlagsgesellschaft, Weinheim, Germany, p. 1169.

Baym, G., Bethe, H.A. and Pethick, C.J., 1971. Neutron Star Matter: Nuclear Physics A, v. 175, p. 225.

Beaudette, C. G., 2000. Excess heat, Why Cold Fusion Research prevailed: Oak Grove Press, LLC, South Bristol, Maine, USA. 
Bernardini, M., Manduchi, C., Mengoli, G. and Zannoni, G., 2000. Anomalous effects induced by $\mathrm{D}_{2} \mathrm{O}$ electrolysis at titanium, in Proc. Eighth International Conference on Cold Fusion, Lerici (La Spezia), Italy 21-26 May 2000, F. Scaramuzzi, ed., Società Italiana di Fisica, p. 39.

Bush, R. T. and Eagleton, R. D., 1993. Experimental studies supporting the transmission resonance model for cold fusion in light water: I. Correlation of isotopic and elemental evidence with excess heat, in Proc. Third International Conference on Cold Fusion, October 21-25, 1992, Nagoya, Japan, Frontiers of Cold Fusion, (H. Ikegami, ed.): Tokyo, Japan, Universal Academy Press, Inc., p. 409.

Bush, R. T. and Eagleton, R. D., 1994. Evidence for electrolytically induced transmutation and radioactivity correlated with excess heat in electrolytic cells with light water rubidium salt electrolytes, in Proc. Fourth International Conference on Cold Fusion, Lahaina, Maui, Dec. 6-9, 1993. EPRI TR-104188V3, 2, Transactions of Fusion Technology, December 1994, v. 26, No. 4T, Part 2, Fuste8 (4) 1-540, American Nuclear Society, La Grange Park, IL, pp. 344354. Also, Bush, R. T. and Eagleton, R. D., 1994. Also, Calorimetric studies for several light water electrolytic cells with nickel fibrex cathodes and electrolytes with alkali salts of potassium, rubidium and cesium, in Proc. Fourth International Conference on Cold Fusion, Lahaina, Maui, Dec. 6-9, 1993. EPRI TR-104188-V2, 13. 
Celani, F., Spallone, A., Tripodi, P., Nuvoli, A., Petrocchi, A., Di Gioacchino, D., Boutet, M, Marini, P. and Di Stefano, V., 1994. High power $\mu$ s pulsed electrolysis for high deuterium loading in $\mathrm{Pd}$ plates, in Proc. Fourth International Conference on Cold Fusion, Lahaina, Maui, Dec. 6-9, 1993. EPRI TR-104188-V3, 2, Transactions of Fusion Technology, December 1994, v. 26, No. 4T, Part 2, Fuste8 (4) 1-540, American Nuclear Society, La Grange Park, IL, pp. 127-137.

Chubb, S. R. and Chubb, T. A., 2000. Theoretical framework for Anomalous Heat and ${ }^{4} \mathrm{He}$ in Transition Metal Systems, in Proc. Eighth International Conference on Cold Fusion, Lerici (La Spezia), Italy 21-26 May 2000, F. Scaramuzzi, ed., Società Italiana di Fisica, pp. 385-390. Also, Chubb, T. A. and Chubb, S. R., 2000. Deuteron Fluxing and the Ion Band State Theory, in Proc. Eighth International Conference on Cold Fusion, Lerici (La Spezia), Italy 21-26 May 2000, F. Scaramuzzi, ed., Società Italiana di Fisica, pp. 391-396.

Close, F., 1991. Too hot to handle: the race for cold fusion: Princeton University Press, Princeton, NJ.

Cotton, F. A., 1988. Advanced inorganic chemistry: Wiley-Interscience, New York. 
Cousins, C. A., M.S. Thesis, 1982. Effects on electrolytic cells of magnetic fields applied to single electrodes: Physics department, Portland State University, Portland, OR.

Crowley, B. J. B., 1989. Nuclear fusion in high density matter: Nuclear Fusion, v. 29, p. 2199.

Darling, A. S., 1973, in Metals Handbook, Vol. 8: Metallography, Structures and phase diagrams, $8^{\text {th }}$ edition, Lyman, T., Boyer, H. E., Carnes, W. J., Chevalier, M. W., Durand, E. A., Baker, H., Harvey, P. D., Waldorf, H. L., Bukovics, H. V., Kirkpatrick, C. W., Kothera, J. W., Eds.: American Society for Metals, Metals Park, OH, p. 309.

Dash, J., Noble, G. and Diman, D., 1994. Surface morphology and microcomposition of palladium cathodes after electrolysis in acidified light and heavy water: correlation with excess heat, in Proc. Fourth International Conference on Cold Fusion, Lahaina, Maui, Dec. 6-9, 1993. EPRI TR-104188V3, 2, Transactions of Fusion Technology, December 1994, v. 26, No. 4T, Part 2, Fuste8 (4) 1-540, American Nuclear Society, La Grange Park, IL, pp. 299306.

Dash, J., Kopecek, R., Miguet, S., 1997. Excess heat and Unexpected Elements from Aqueous Electrolysis with Titanium and Palladium Cathodes, presented at the Proceedings of the $32^{\text {nd }}$ Intersociety Conversion Engineering Conference. 
Dedieu, ed., 1992. Transition metal hydrides: VCH Publishers, New York.

Dougar-Jabon, V. D., Kariaka, V. I., Samsonenko, N. V., 2000. Study of the neutron and $\gamma$-Emission from the Palladium-Deuterium System in the Process of the Transformation of the Crystalline Structure, in Proc. Eighth International Conference on Cold Fusion, Lerici (La Spezia), Italy 21-26 May 2000, F. Scaramuzzi, ed., Società Italiana di Fisica.

Dufour, J., Foos, J. and Millot, J. P., 1994. Excess energy in the system palladium/hydrogen isotopes measurement of the excess energy per atom hydrogen, in Proceedings of the Fifth International Conference on Cold Fusion, Monte-Carlo, Monaco April 9-13, 1995, IMRA Europe, France, 495.

Fisher, J.C., 1998. Liquid-Drop Model for Extremely Neutron Rich Nuclei: Fusion Technology, v. 34, p. 66.

Flanagan, T. B. and Oates, W. A., 1978. Palladium-hydrogen: The classical metalhydrogen system, in Bau, R., Ed., Transition Metal Hydrides, American Chemical Society, Washington DC., pp. 283-301.

Fleischmann, M., Pons, S., 1989. Electrochemically-induced nuclear fusion of deuterium: J. Electroanal. Chem. 261, 301.

Focard, S., Habel, R. and Piantelli, F., 1994. Anomalous heat production in Ni-H systems: Il Nuovo Cimento, v. 107A, p. 163. 
Fukai, Y., 1981. Solid state physics (in Japanese), v. 16, No. 5, p. 253.

Gozzi, D., Cignini, P.L., Petrucci, L, Tomellini, M. and Maria, G. De, 1990. Evidences for associated heat generation and nuclear products release in $\mathrm{Pd}$ heavy-water electrolysis: Il Nuovo Cimento, v. 103, p. 143.

Gozzi, D., Cignini, P. L., Tomellini, M., Frullani, S., Garibaldi, F., Ghio, F., Jodice, M. and Urciuoli, G. M., 1991. Multicell experiments for searching time-related events in cold fusion: Proc. Of the Second Annual Conference on Cold Fusion, Como, Italy, June 29-July 4, 1991, The science of cold fusion, v. 33 (T. Bressani, E. Del Giudice and G. Preparata, eds.), 21.

Hagelstein, P. L., 2000. A unified model for anomalies in metal deuterides, in Proc. Eighth International Conference on Cold Fusion, Lerici (La Spezia), Italy 21-26 May 2000, F. Scaramuzzi, ed., Società Italiana di Fisica.

Halley, J.W. and Valles, J.L., 1990. Estimate of nuclear fusion rates arising from a molecular-dynamics model of PdD : Phys. Rev. B, v. 41, p. 6072.

Hemminger, W. and Hohne, G., 1984. Calorimetry, Fundamentals and Practice, Verlag Chemie, Weinheim, Germany.

Hoffman, N., 1995. A dialogue on chemically-induced nuclear effects: a guide for the perplexed about cold fusion: American Nuclear Society, La Grange Park, IL. 
Hugo, M., 1994. A home cold fusion experiment, in Proc. Fourth International Conference on Cold Fusion, Lahaina, Maui, Dec. 6-9, 1993. EPRI TR-104188V2, 22.

Huizenga, J. R., 1994. Cold fusion: the scientific fiasco of the century: Oxford University Press, Oxford, naturally.

Hurd, D. T., 1952. Chemistry of the hydrides: John Wiley\&Sons, New York.

Jones, S. E., Palmer, E. P., Czirr, J. B., Decker, D. L., Jensen, G. L., Thorne, J. M. S., Taylor, F. and Rafelski, J., 1989. Observation of cold nuclear fusions in condensed matter: Nature, v. 338, p. 737.

Karabut, A. B., Kucherov, Ya. R. and Savvatimova, I. B., 1992. Nuclear product ratio for glow discharge in deuterium: Phys. Lett. A, v. 170, p. 265. Also Karabut, A. B., Kucherov, Ya. R. and Savvatimova, I. B. Cold Fusion observation at gas-discharge device cathode, in Anniversary Specialist Conference on Nuclear Power Engineering in Space, Obninsk, Russia, 15-19 May 1990; Karabut, A. B., Kucherov, Ya. R. and Savvatimova, I. B., 1992. Possible nuclear reactions mechanisms at glow discharge in deuterium, in Proc. Third International Conference on Cold Fusion, October 21-25, 1992, Nagoya, Japan, Frontiers of Cold Fusion, (H. Ikegami, ed.), 165; Savvatimova, I. B., Kucherov, Ya. R. and Karabut, A. B., 1994. Cathode material change after deuterium glow discharge experiments, in Proc. Fourth International 
Conference on Cold Fusion, Lahaina, Maui, Dec. 6-9, 1993. EPRI TR-104188V3, 16.

Keefe, P. S., M.S. Thesis, 1990. Comparison of Light and Heavy Water Electrolysis with palladium cathodes, Physics department, Portland State University, Portland, OR.

Kozima, H., 1998. Discovery of the Cold Fusion Phenomenon: Development of Solid State - Nuclear Physics and the Energy Crisis in the $21^{\text {st }}$ century: Ohtake Shuppan Inc., Tokyo, Japan.

Kozima, H., Kaki, K., and Ohta, M., 1998. Anomalous Phenomenon in Solids Described by the TNCF Model: Fusion Technology, v. 33, p. 52.

Kozima, H., 2000. Neutron Drop; Condensation of Neutrons in Metal Hydrides and Deuterides: Fusion Technology, v. 37, p. 253.

Lewis, D. and Sköld, K., 1990. A phenomenological study of the FleischmannPons effect: J. Electroanal. Chem., v. 294, p. 275.

Liaw, B. Y., Tao, P-L., Turner, P. and Liebert, B., 1990. Elevated temperature excess heat production using molten-salt electrochemical techniques, in Proc. Cold Fusion Symposium, $8^{\text {th }}$ World Hydrogen Energy Conference, Honolulu, HI, July 22-27, 1990, 47. Also, Liaw, B. Y., Tao, P. L. and Liebert, B. E., 1991. Recent progress on cold fusion research using molten salt techniques, in 
Proc. Second Annual Conference on Cold Fusion, Como, Italy, June 29-July 4, 1991, The Science of Cold Fusion, v. 33 (T. Bressani, E. Del Giudice and G. Preparata, eds.), 55.

Li, X. Z., Yan, Y. J., Tian, J., Mei, M. Y., Deng, Y., Yu, W. Z., Tang, G. Y., Cao, D. X., De Ninno, A., 2000. Nuclear Transmutation in Pd Deuteride, in Proc. Eighth International Conference on Cold Fusion, Lerici (La Spezia), Italy 21-26 May 2000, F. Scaramuzzi, ed., Società Italiana di Fisica.

Lide, R. D., 1993. CRC Handbook of Chemistry and Physics, $74^{\text {th }}$ edition, CRC Press, Boca Raton, FL.

McKubre, M., Bush, B., Crouch-Baker, S., Hauser, A., Jevtic, N., Smedley, S., Srinivasan, M., Tanzella, F., Williams, M. and Wing, S., 1994. Loading, calorimetric and nuclear investigation of the D/Pd system, in Proc. Fourth International Conference on Cold Fusion, Lahaina, Maui, Dec. 6-9, 1993. EPRI TR-104188-V1, 5.

McKubre, M., 1999. Recent loading and Excess heat experiments at SRI, in Proc. ASTI Workshop on Anomalies in H-loaded metals, Nov. 27-30, Asti, Italy, Società Italiana di Fisica.

Miles, M. H. and Bush, B. F., 1994. Heat and helium measurements in deuterated palladium, in Proc. Fourth International Conference on Cold Fusion, Lahaina, 
Maui, Dec. 6-9, 1993. EPRI TR-104188-V3, 2, Transactions of Fusion Technology, December 1994, v. 26, No. 4T, Part 2, Fuste8 (4) 1-540, American Nuclear Society, La Grange Park, IL, pp. 156-159.

Miles, M. H., 1995. The extraction of Information from an integrating open calorimeter in Fleischmann-Pons effect experiments, in Proc. Fifth International Conference on Cold Fusion, Monte-Carlo, Monaco, (ICCF-5, Valbonne, France), p. 97-104.

Miley, G. H., Selvaggi, G., Tate, A., Okuniewski, M., Williams, M. J., Chicea, D., Horam H., Kelly, J., 2000. Advances in thin-film electrode experiments, in Proc. Eighth International Conference on Cold Fusion, Lerici (La Spezia), Italy 21-26 May 2000, F. Scaramuzzi, ed., Società Italiana di Fisica.

Mills, R. L. and Kneizys, S. P., 1991. Excess heat production by the electrolysis of an aqueous potassium carbonate electrolyte and the implications for cold fusion. Fusion Technology, v. 20, p. 65.

Mills, R. L., Good, W. R. and Shaubach, R. M., 1992. Unification of spacetime, the forces, matter and energy: Ephrata, PA, Science Press, 17522.

Mills, R. L., Good, W. R. and Shaubach, R. M., 1994. Dihydrino molecule identification: Fusion Technology, v. 25, p. 103. 
Mizuno, T., Enyo, M., Akimoto, T. and Azumi, K., 1994. Anomalous heat evolution from $\mathrm{SrCeO}_{3}$-type proton conductors during absorption/desorption in alternate electric field, in Proc. Fourth International Conference on Cold Fusion, Lahaina, Maui, Dec. 6-9, 1993. EPRI TR-104188-V2, 14.

Mizuno, T., Akimoto, T., Ohmori, T., Takahashi, A., Yamada, H. and Numata, H., 2001. Neutron evolution from a Palladium electrode by alternate absorption treatment of deuterium and hydrogen: Jpn. J. Appl. Phys., v. 40, p. L989-L991 Part 2, No. 9A/B.

Morse, P. M., 1969. Thermal physics, W.A. Benjamin, Inc., New York.

Mueller, W.M., Blackledge, J.P., Libowitz, G.G., 1968. Metal hydrides, Academic Press, San Diego, CA.

Negele, J.W. and Vautherin, D., 1973. Neutron Star Matter at Sub-nuclear Densities: Nuclear Physics A, v. 207, p. 298.

Nicholas, E. N., 1992. Looking for evidence of cold fusion: Electrolysis of $\mathrm{D}_{2} \mathrm{O}$ at a palladium cathode, submitted in partial fulfillment of the M.S. degree, Physics department, Portland State University, Portland, OR.

Noble, G. L., M.S. Thesis, 1994. Morphology and microanalysis of palladium cathodes after electrolysis in light and heavy water, Physics department, Portland State University, Portland, OR. 
Noble, G., Dash, J., Breiling, M., 1995. Electrolysis of heavy water with a palladium and sulfate composite, in Proceedings of the $5^{\text {th }}$ International Conference on Cold Fusion (IMRA Europe, SA).

Notoya, R. and Enyo, M., 1993. Excess heat production during electrolysis of $\mathrm{H}_{2} \mathrm{O}$ on $\mathrm{Ni}, \mathrm{Au}, \mathrm{Ag}$ and $\mathrm{Sn}$ electrodes in alkaline media, in Proc. Third International Conference on Cold Fusion, October 21-25, 1992, Nagoya, Japan, Frontiers of Cold Fusion, (H. Ikegami, ed.): Tokyo, Japan, Universal Academy Press, Inc., p. 421 .

Notoya, R., 1995. Nuclear products of cold fusion caused by electrolysis in alkali metallic ions solutions, in Proceedings of the $5^{\text {th }}$ International Conference on Cold Fusion, Monte Carlo, Monaco April 9-13, 1995, IMRA Europe, France 531.

Ota, K., Yoshitake, H., Yamazaki, O., Kuratsuka, M., Yamaki, K., Ando, K., Iida, Y., Kamiya, N., 1994. Heat measurement of water electrolysis using Pd cathode and the electrochemistry, in Proc. Fourth International Conference on Cold Fusion, Lahaina, Maui, Dec. 6-9, 1993. EPRI TR-104188-V2, 5, Transactions of Fusion Technology, December 1994, v. 26, No. 4T, Part 2, Fuste8 (4) 1-540, American Nuclear Society, La Grange Park, IL, pp. 138-142.

Peat, D. F., 1989. Cold fusion: the making of a scientific controversy: Contemporary Books, Chicago, IL. 
Ramamurthy, H., Srinivasan, M., Mukherjee, U. K. and Adi Babu, P., 1994. Further studies on excess heat generation in $\mathrm{Ni}-\mathrm{H}_{2} \mathrm{O}$ electrolytic cells, in Proc. Fourth International Conference on Cold Fusion, Lahaina, Maui, Dec. 6-9, 1993. EPRI TR-104188-V2, 15. Also, Sankaranarayanan, M., Srinivasan, M., Bajpai and Gupta, D., 1994. Investigation of low level tritium generation in Ni$\mathrm{H}_{2} \mathrm{O}$ electrolytic cells, in Proc. Fourth International Conference on Cold Fusion, Lahaina, Maui, Dec. 6-9, 1993. EPRI TR-104188-V3, 3.

Rahman, A., Sköld K., Pelizzari, K., Sinha, S. K., 1976. Phonon spectra of nonstoichiometric palladium hydrides: Phys. Rev. B, v. 14, pp. 3630-3634.

Riley, D., McLaughlin, M., 2001. Turning the Corner: Energy Solutions for the 21st Century: Alternative Energy Institute, Inc., PO Box 7074, Tahoe City, CA 96145.

Rosen, G., 1989. Deuterium nuclear fusion at room temperature: A pertinent inequality on barrier penetration: J. Chem. Phys., v. 91, p. 4415.

Rossini, F.D., 1961. Selected values of chemical thermodynamic properties, Part I, Tables: National Bureau of Standards Circular 500, US Department of commerce.

Rothman, M. 1990. Cold fusion: A case history in "wishful science"?: Skeptical Inquirer, v. 14, No. 2. 
Sander, U.H.F., Fischer, H., Rothe, U., Kola, R., 1984. Sulphur, suplhur dioxide and sulphuric acid: An introduction to their industrial chemistry and technology, The British Sulphur Corporation Ltd., London.

Silver, D. and Dash, J., 1999. SEM and EDS characterization of palladium cathodes after electrolysis in light and heavy water, presented at the Microscopy and Microanalysis 5, Portland OR.

Storms, E., 1991. Collected information about the new science of chemical-nuclear interactions: Fusion Technology, v. 20.

Stringham, R. and George, R., 1993. Work presented at the Fourth International Conference on Cold Fusion, Lahaina, Maui, Dec. 6-9, 1993. EPRI TR-104188V2, 4, but not published in proceedings. Details can be found at Infinite Energy, 1, 1, 1995. P.O. Box 2816 Concord, NH 03302-2816. Supplementary technical information can be obtained at E-Quest Sciences, P. O. Box 60642, Palo Alto, CA 94036.

Szpak, S., Mosier-Boss, P.A., Smith, J.J., 1991. On the behavior of Pd deposited in the presence of evolving deuterium, J. Electroanal. Chem., v. 302, p. 255.

Szpak, S., Mosier-Boss, P.A., Eds., 2002. Thermal and Nuclear Aspects of the $\mathrm{Pd} / \mathrm{D}_{2} \mathrm{O}$ system, Volume 1, U.S. Navy Technical Report 1862 (February 2002): SPAWAR, Systems Center San Diego, CA, 92152-5001. 
Taubes, G., 1993. Bad science: The short life and weird times of cold fusion: Random House, New York.

Vargaftik, N.B., 1975. Tables on the thermophysical properties of liquids and gases (in normal and dissociated states: Hemisphere Publishing Corporation, Washington DC.

Warner, J., M.S. Thesis, 1998. Observations of heat produced and chemical changes caused by electrolysis of titanium with heavy water, Physics department, Portland State University, Portland, OR.

Warner, J., Ph.D. thesis, 2001. Interactions of titanium with hydrogen isotopes, Physics department, Portland State University, Portland, OR.

Zhang, W.-S., Zhang, Z.-L., Zhang, X.-W., 2000. Effects of temperature on loading ratios of hydrogen (deuterium) in Palladium Cathodes under the Galvanostatic Condition, in Proc. Eighth International Conference on Cold Fusion, Lerici (La Spezia), Italy 21-26 May 2000, F. Scaramuzzi, ed., Società Italiana di Fisica. 


\section{APPENDIX A:}

\section{CALIBRATION OF THE TEMPERATURE SENSORS}

IN THE SECOND EXPERIMENT

The two Radio-Shack LCD Dual Display Indoor/Outdoor thermometers read the temperature with their 3 foot long sensors to $\pm 1{ }^{\circ} \mathrm{C}$ and were be calibrated after the second experiment with the help of a mercury thermometer, a water bath and a stove. The relationship between the digital thermometer reading in ${ }^{\circ} \mathrm{C} x$ and the mercury thermometer temperature in ${ }^{\circ} \mathrm{C}$ turned out to be:

$T=0.96 x+0.96 \quad R^{2}=1.00$,

for the digital sensor that went to the bottom of the $\mathrm{H}$ cell, and:

$T=0.97 x+1.26 \quad R^{2}=1.00$

for the digital sensor that went to the bottom of the $\mathrm{D}$ cell.

The calibration of the thermocouples was done in a similar fashion. 


\section{APPENDIX B: THERMAL EVOLUTION OF CELLS IN THE FIRST EXPERIMENT}

In the first experiment, the indications from the strip chart recorder were that the $\mathrm{H}$ cell was slightly warmer than the $\mathrm{D}$ cell. The $\mathrm{H}$ cell temperature began to exceed the $\mathrm{D}$ cell temperature within one hour of switch-on of the first run of this experiment on October 29, 2001, right after steady-state was achieved.

Over the course of this first 30.9 hour run, the $\mathrm{H}$ cell lost 8.35 grams $(0.463$ moles of $\left.\mathrm{H}_{2} \mathrm{O}\right)$ and the $\mathrm{D}$ cell lost 9.17 grams $\left(0.459\right.$ moles of $\left.\mathrm{D}_{2} \mathrm{O}\right)$.

FIG. 20: Thermal evolution of the cells in the first run of the first experiment. Ambient temperature was recorded at the midpoint between the cells. The error of the temperature points is estimated at $\pm 1^{\circ} \mathrm{C}$.

First experiment, 1st run, October 29-30, 2001

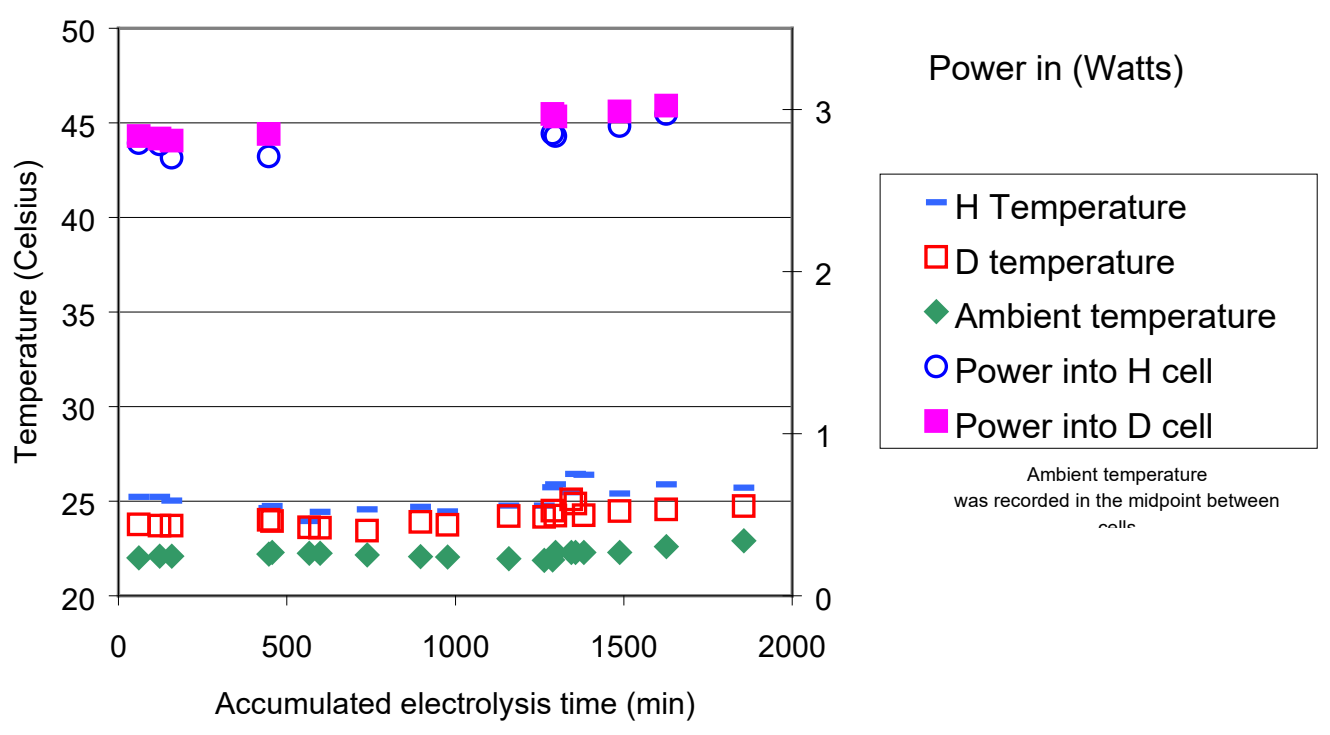


The loss over the second 30 hour run of this first experiment was 7.95 grams $(0.442$ moles of $\left.\mathrm{H}_{2} \mathrm{O}\right)$ for the $\mathrm{H}$ cell and 10.26 grams $\left(0.513\right.$ moles of $\left.\mathrm{D}_{2} \mathrm{O}\right)$ for the $\mathrm{D}$ cell.

FIG. 21: Cells' thermal evolution in the second run of the first experiment. Ambient temperature was recorded in the midpoint between the cells. The error of the temperature points is estimated at $\pm 1{ }^{\circ} \mathrm{C}$.

Figure 2: First experiment, 2nd run, November 1-2, 2001

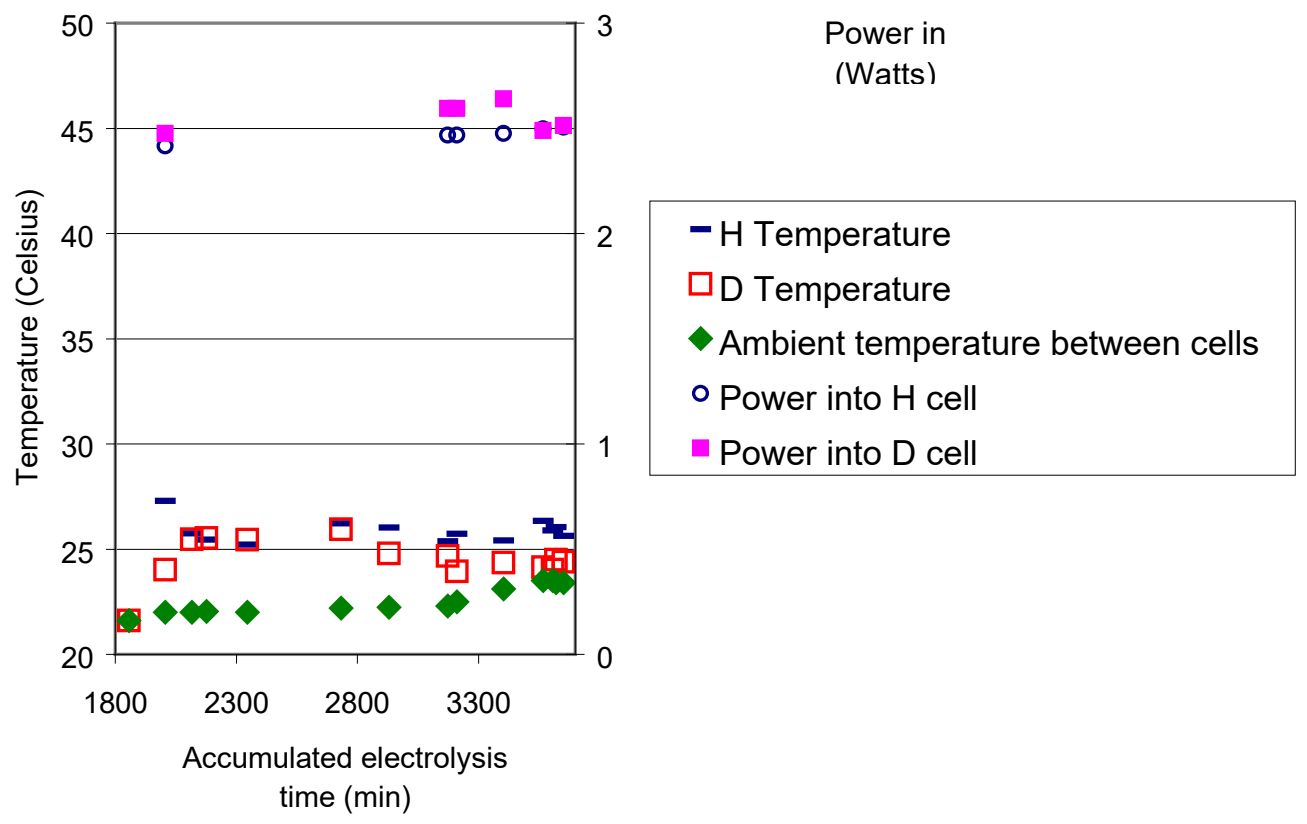

After this first experiment, the cathode of the $\mathrm{H}$ cell finished slightly more bent towards the anode $\left(\sim 10^{\circ}\right)$ than the cathode of the D cell. 


\section{APPENDIX C: DETAILED FOLLOW-UP OF SECOND EXPERIMENT}

This appendix is a day-by-day follow-up of the second experiment.

-Run of December 21, 2001

Power was switched on on December 21, 2001 at 4:03 PM for the first run of electrolysis. It would be found later that in this first run the D cell had been run with the polarity switched by mistake.

With the $\mathrm{H}$ cell at $3.20 \mathrm{~V}$ and the $\mathrm{D}$ cell at $2.80 \mathrm{~V}$ it took the $\mathrm{D}$ cell only a few minutes to exceed the $\mathrm{H}$ cell in temperature. At 4:15 PM, the two thermocouples of the $\mathrm{H}$ cell were reading $23{ }^{\circ} \mathrm{C}$ (cathode side) and $24.2{ }^{\circ} \mathrm{C}$ (anode side); while the thermocouples of the D cell were already reading $24.5{ }^{\circ} \mathrm{C}$ (cathode side) and $25{ }^{\circ} \mathrm{C}$ (anode side), after correcting for calibration. By 5:03 PM steady-state had been reached. The cathode side of the $\mathrm{H}$ cell was at $30.1{ }^{\circ} \mathrm{C}$ while the cathode side of the D cell was at $31.3{ }^{\circ} \mathrm{C}$. At this point the $\mathrm{H}$ cell was at $3.20 \mathrm{~V}$ while the $\mathrm{D}$ cell was at 2.72. Unfortunately, at 8:24 PM the D cell developed a short-circuit and the data acquisition had to be aborted for the day. The circuit was switched off. At that point, the recordings had become rather erratic but the obviously valid readings 
gave a calibration-corrected temperature of $33.1{ }^{\circ} \mathrm{C}$ for the cathode side of the $\mathrm{D}$ cell in contrast to $31.7{ }^{\circ} \mathrm{C}$ for the same side of the $\mathrm{H}$ cell.

It was noticed that the electrolyte of the $\mathrm{D}$ cell had become almost totally black, to the point that the electrodes were hard to see. It would be realized on the next day that this had been because of the accidental switching-on of the D cell with the wrong polarity, which had dissolved palladium.

FIG. 22: Power input versus temperature chart for the cells in the run of December 21, 2001. The estimated error bar of the temperature readings in all the runs of this second experiment was $\pm 0.4{ }^{\circ} \mathrm{C}$, the standard deviation of the thermocouple recordings. It is also approximately the size of the temperature data points in the graphs.

Run of December 21, 2001, with D polarity reversed. Duration: 261 minutes.

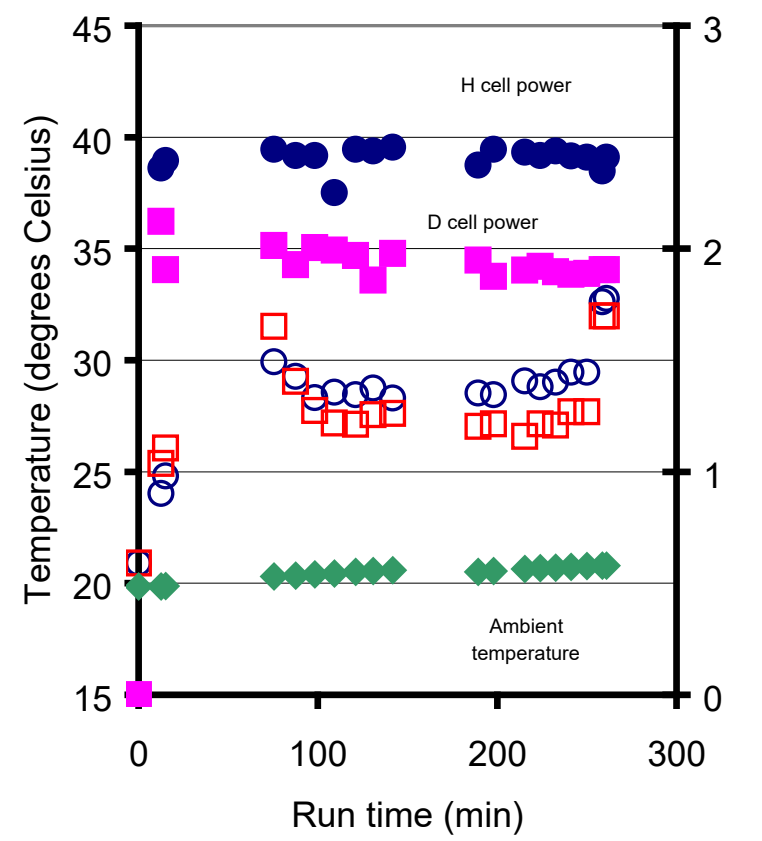

$$
\begin{aligned}
& \text { Cell } \\
& \text { power } \\
& \text { input }
\end{aligned}
$$
(watts)

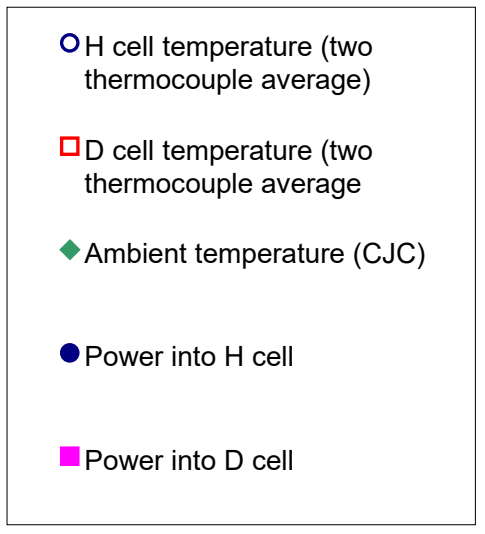

Run time (min) 


\section{-Run of December 22, 2001}

In the following morning the cells were removed from their positions in the circuit and weighed. The $\mathrm{H}$ cell had lost 1.37 grams $\left(0.076\right.$ moles of $\left.\mathrm{H}_{2} \mathrm{O}\right)$ and the D cell had lost 1.11 grams $\left(0.055\right.$ moles of $\left.\mathrm{D}_{2} \mathrm{O}\right)$ since the previous weighing just before the start of the first run. A cluster of blackish threads had originated from the anode and bridged to the cathode. Other threads had come to settle overnight at the bottom of the D cell. The substance that made up those threads, probably PdS or $\mathrm{PdO}$, had been in suspension in the previous run in the electrolyte and had clearly been responsible for its black coloration. It was then that it was realized that the anode of the D cell had been used as cathode by mistake.

The data of the previous day were still valid, however. In fact, the blackish flakelike coating had been found before in another experiment reported in the literature ${ }^{5}$ in which the Pt terminal had been used as working cathode and excess heat had been detected in the D cell. Nevertheless, it was better to resume the experiment as originally intended and the electrodes of the D cell were hooked up properly.

A brief run was then taken from 9:12 PM to 9:38 PM on December 22 2001. The H cell voltage was set at $3.19 \mathrm{~V}$ and the $\mathrm{D}$ cell at $2.87 \mathrm{~V}$. Two minutes into the run, the $\mathrm{H}$ cell was averaging (after correcting for calibration) $21.3{ }^{\circ} \mathrm{C}$ compared with 24.2 ${ }^{\circ} \mathrm{C}$ of the $\mathrm{D}$ cell. Seven minutes into the run, the $\mathrm{D}$ cell was registering already $24.7{ }^{\circ} \mathrm{C}$ while the $\mathrm{H}$ cell was still lingering at $21.8{ }^{\circ} \mathrm{C}$. At the end of this 
brief run, the cathode side of the $\mathrm{D}$ cell was at $31.8{ }^{\circ} \mathrm{C}$ while the $\mathrm{H}$ cell cathode side was at $25.2{ }^{\circ} \mathrm{C}$.

A partial explanation for such a surprisingly high temperature of the D cell compared to the $\mathrm{H}$ cell might have been that the $\mathrm{D}$ cell was set $0.6 \mathrm{~V}$ higher than the $\mathrm{H}$ between minute 5 and minute 12 of this brief run.

It was noteworthy that the blackish, thread-like material in the D cell electrolyte had then switched from the anode to the cathode. The substance had dangled around rather flaccidly during the run but seemed to condense around the cathode after the current was switched off.

FIG. 23: Power input versus temperature chart for the cells in the run of December 22, 2001.

Run of December 22, 2001. Duration: 26 minutes.

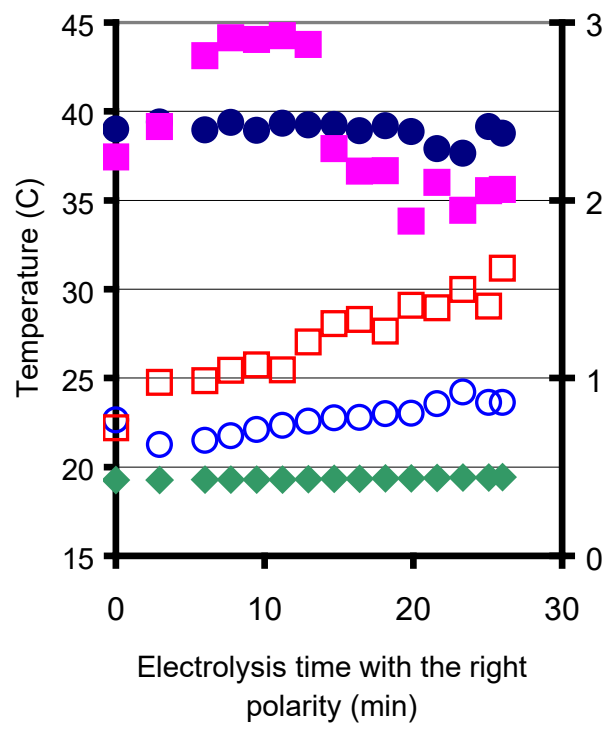

Cell power

input

(watts)

$\checkmark$ Ambient temperature (CJC)

$\mathrm{OH}$ cell temperature (two thermocouple average)

$\square \mathrm{D}$ cell temperature (two thermocouple average)

- Power into $\mathrm{H}$ cell

Power into D cell 


\section{-Run of December 23, 2001}

The third run was started in the afternoon of December 232001 at 12:57 PM.

After running for 75 minutes, the Radio-Shack LCD Dual Display temperature sensor underneath the $\mathrm{D}$ cell, which was at $2.89 \mathrm{~V}$, was already reading a calibration-corrected temperature of $25.4{ }^{\circ} \mathrm{C}$, while the probe under the $\mathrm{H}$ cell, which was at $3.16 \mathrm{~V}$, was displaying $25.1{ }^{\circ} \mathrm{C}$. Meanwhile the cathode-side thermocouples were registering calibration-corrected temperatures of $33.7{ }^{\circ} \mathrm{C}$ for the D cell and $28.9{ }^{\circ} \mathrm{C}$ for the $\mathrm{H}$ cell. At 2:24 PM the D cell had clearly surpassed the $\mathrm{H}$ cell, displaying $26.1{ }^{\circ} \mathrm{C}$ for $25.5{ }^{\circ} \mathrm{C}$ of the $\mathrm{H}$ cell, with the $\mathrm{H}$ cell voltage at $3.16 \mathrm{~V}$ and the $\mathrm{D}$ cell voltage at $2.91 \mathrm{~V}$.

At 2:37 PM the gap in favor of the D cell was already $0.9{ }^{\circ} \mathrm{C}$. At 3:13 PM, the cathode side of the $\mathrm{H}$ cell was at $29.3{ }^{\circ} \mathrm{C}$ while the cathode side of the D cell was at $29.6{ }^{\circ} \mathrm{C}$. The $\mathrm{H}$ cell was receiving $3.14 \mathrm{~V}$ while the $\mathrm{D}$ cell was receiving $2.89 \mathrm{~V}$.

At 3:15 PM, 2h18' into the run, the cathode side of the $\mathrm{H}$ cell was reading (correcting for calibration) $30.6{ }^{\circ} \mathrm{C}$ while the same area on the $\mathrm{D}$ cell was at 32.5 ${ }^{\circ} \mathrm{C}$. The probe underneath the $\mathrm{H}$ cell read $25.9{ }^{\circ} \mathrm{C}$ and the one underneath the $\mathrm{D}$ cell read $26.2{ }^{\circ} \mathrm{C}$, which translated to a $0.6{ }^{\circ} \mathrm{C}$ difference in favor of the $\mathrm{D}$ cell after correcting for calibration. The D cell was clearly warmer. The D cell was at $2.67 \mathrm{~V}$ while the $\mathrm{H}$ cell was at a full $3.13 \mathrm{~V}$, which was very significant.

Data acquisition was stopped at 3:42 PM for the day. 
The cells were removed from the circuit and weighed at 5:30 PM: the H cell had lost 2.33 grams $\left(0.13\right.$ moles of $\left.\mathrm{H}_{2} \mathrm{O}\right)$ and the $\mathrm{D}$ cell had lost 1.80 grams $(0.09$ moles of $\mathrm{D}_{2} \mathrm{O}$ ) in the accumulated $7 \mathrm{~h} 33^{\prime}$ ' total of electrolysis since the start of the first run.

FIG. 24: Power input versus temperature chart for the cells in the run of December 23,

$$
2001 .
$$

Run of December 23, 2001. Duration: 166 minutes.

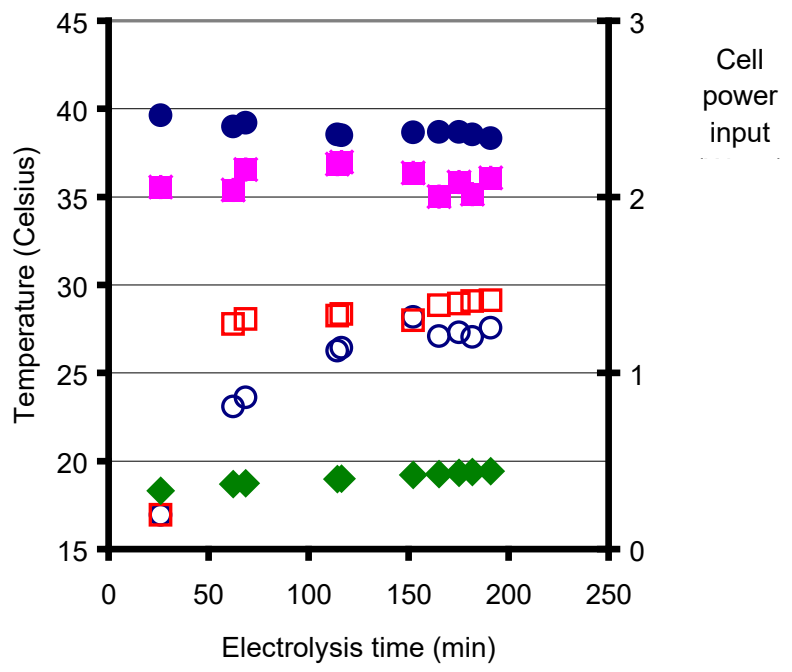

OH cell temperature (two thermocouple average)

$\square \mathrm{D}$ cell temperature (two thermocouple average)

$\checkmark$ Ambient temperature (CJC)

- Power into H cell

Wower into D cell

-Run of December 27, 2001

On December 272001 a new run was started at 3:30 PM with temperature data being acquired by the thermocouples every 2 minutes. 
On this day, the $\mathrm{D}$ cell lagged just below the $\mathrm{H}$ cell all afternoon and did not manage to surpass the latter in temperature. The D cell throughout this whole session at an average of $2.82 \mathrm{~V}$, while the $\mathrm{H}$ cell was at an average of $3.09 \mathrm{~V}$.

At 4:59 PM, for example, the rear of the $\mathrm{D}$ cell was at $31.7{ }^{\circ} \mathrm{C}$ while the rear of the H cell was at $31.2{ }^{\circ} \mathrm{C}$, but the front of the D cell was at $32.5{ }^{\circ} \mathrm{C}$ while the front of the $\mathrm{H}$ cell was at $33.3{ }^{\circ} \mathrm{C}$, according to the thermocouples. The bottom of the $\mathrm{D}$ cell was at $26.8{ }^{\circ} \mathrm{C}$ while the bottom of the $\mathrm{H}$ cell was at $27{ }^{\circ} \mathrm{C}$. The $\mathrm{H}$ cell was at $3.12 \mathrm{~V}$ while the $\mathrm{D}$ cell was at $2.82 \mathrm{~V}$.

FIG. 25: Power input versus temperature chart for the cells in the run of December 27, 2001.

Run of December 27, 2001. Duration: 329 minutes.

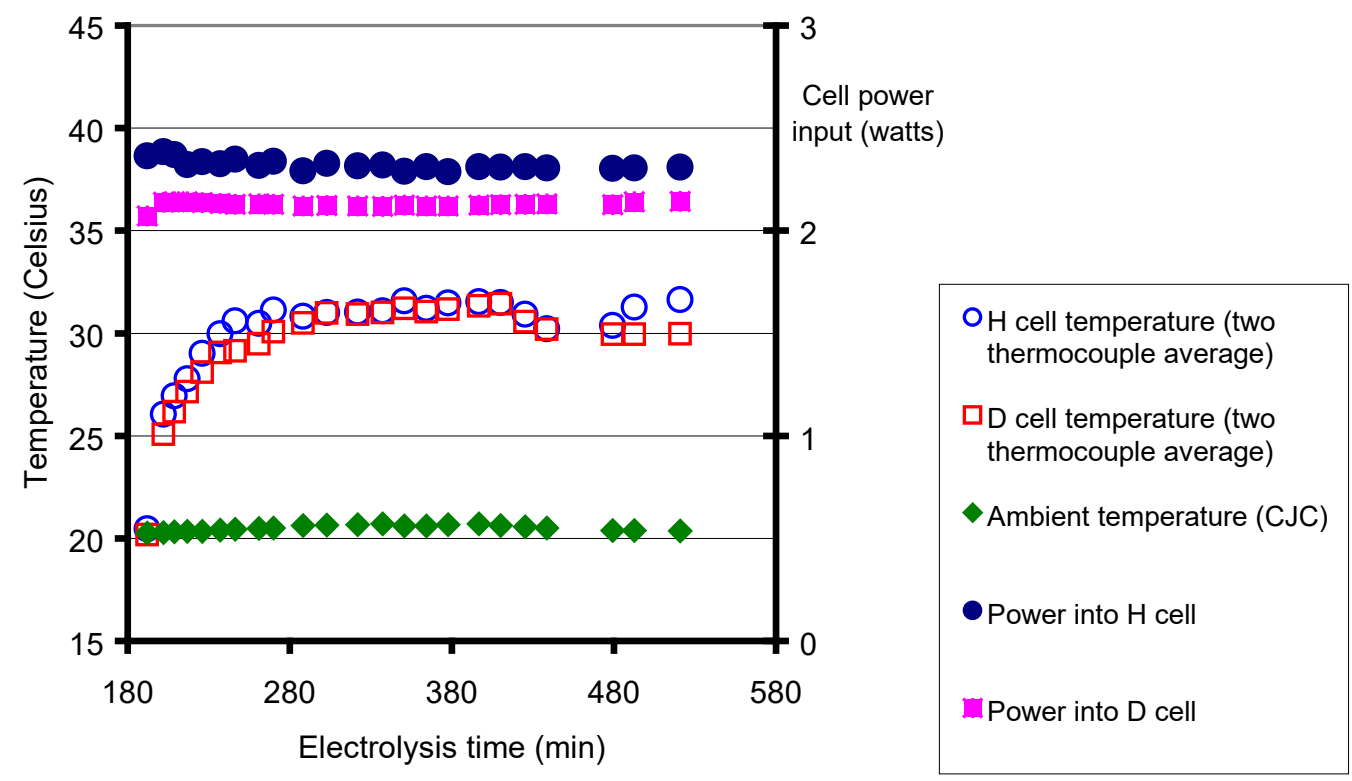




\section{-Run of January 7, 2002}

A fresh run was started at 9:19 AM on January 72002.

As early as 11:44 AM, the D cell had surpassed the temperature of the $\mathrm{H}$ cell, even though the $\mathrm{D}$ cell had been all along at $0.3 \mathrm{~V}$ less voltage. The rear of the $\mathrm{D}$ cell was at $33{ }^{\circ} \mathrm{C}$ compared with $30{ }^{\circ} \mathrm{C}$ of the $\mathrm{H}$ cell rear. The bottom of the $\mathrm{D}$ cell was at $27.6{ }^{\circ} \mathrm{C}$ compared with $27.5{ }^{\circ} \mathrm{C}$ of the $\mathrm{H}$ cell bottom. The cathode of the $\mathrm{D}$ cell was clearly bent backwards from the anode $45^{\circ}$, its convex side facing the anode, and the black substance had formed a coat around it. By contrast, the cathode of the $\mathrm{H}$ cell looked the same as before the start of electrolysis.

At $3 \mathrm{PM}$ the bottom of the D cell was at $28{ }^{\circ} \mathrm{C}$ while the bottom of the $\mathrm{H}$ cell was at $27.8{ }^{\circ} \mathrm{C}$. The $\mathrm{H}$ cell was at $3.10 \mathrm{~V}$ while the $\mathrm{D}$ cell was at only $2.81 \mathrm{~V}$.

Upon switching off the circuit that night at 9:30 PM the two cells were stable and registering basically the same temperature at their bottoms: the $\mathrm{H}$ cell was reading $29^{\circ} \mathrm{C}$ and the $\mathrm{D}$ cell was reading $29^{\circ} \mathrm{C}$, but the $\mathrm{H}$ cell was at $3.07 \mathrm{~V}$ while the $\mathrm{D}$ cell was at only $2.89 \mathrm{~V}$. The thermocouple at the front of the $\mathrm{H}$ cell was at that moment reading $32.6{ }^{\circ} \mathrm{C}$ while the one at the back of the $\mathrm{D}$ cell was reading 32.4 ${ }^{\circ} \mathrm{C}$. 
FIG. 26: Power input versus temperature chart for the cells in the run of January 7, 2002.

Run of January 7, 2002. Duration: 731 minutes.

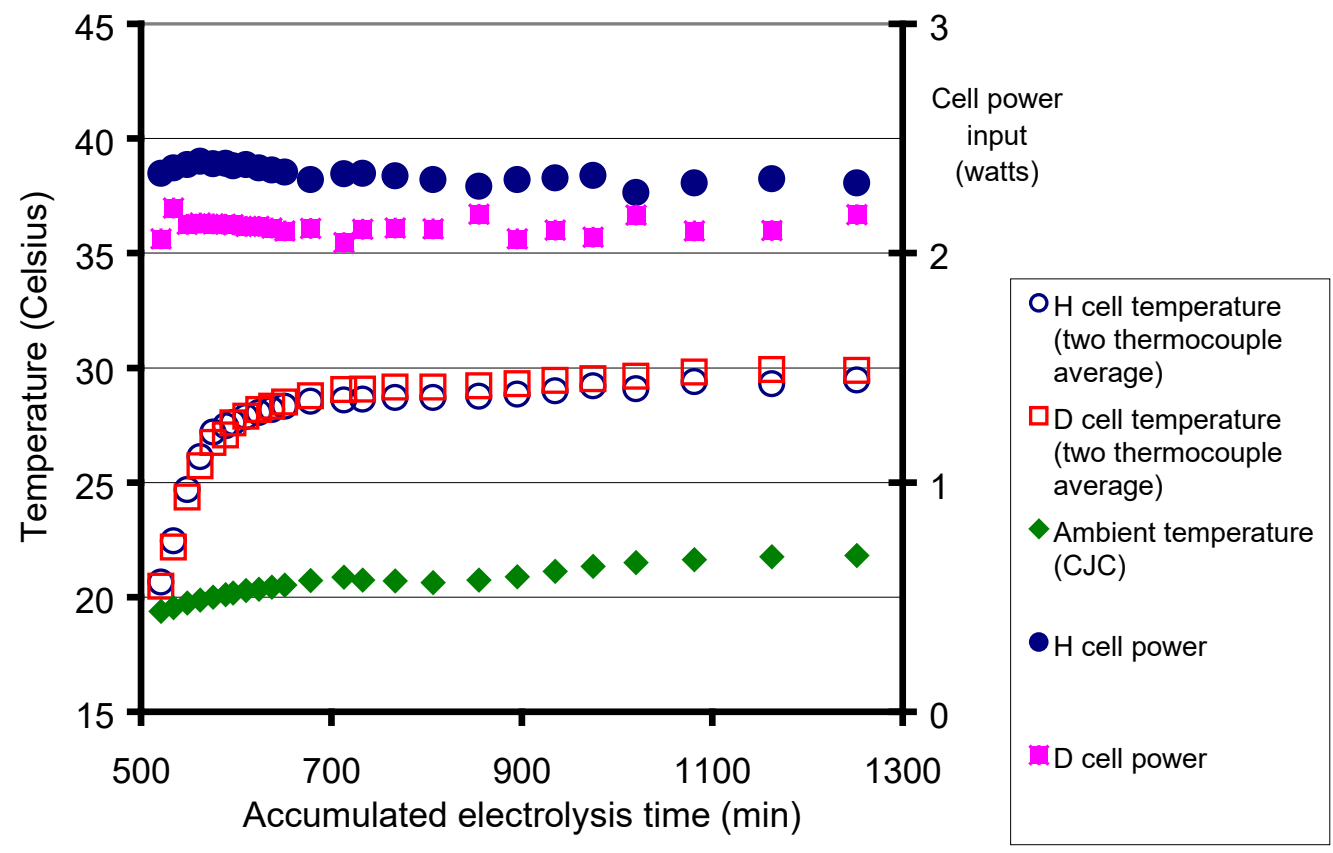

-Run of January 8, 2002

The next run was started at 9:57 AM on the morning of January 8,2002 , and by 11:18 AM the D cell had caught up with the $\mathrm{H}$ cell despite having been at $0.2 \mathrm{~V}$ less voltage (the $\mathrm{D}$ cell had been at $2.91 \mathrm{~V}$ and the $\mathrm{H}$ cell had been at $3.13 \mathrm{~V}$ ). At that point, the bottoms of both cells were at $27.6{ }^{\circ} \mathrm{C}$. For the rest of the day the two cells remained at basically the same temperature, with the $\mathrm{D}$ cell receiving $\sim 10 \%$ less power. 
To get a confirmation that the thermocouple readings were accurate the decision was adopted to use a HH 82 Digital thermometer with another thermocouple as sensor. This instrument with this particular thermocouple as sensor was later calibrated with the use of the same mercury thermometer that had been used to calibrate the cell thermocouples. With this new HH 82 instrument, the cathode side of the electrolyte-covered portion of D cell glass was measured to be clearly warmer than the corresponding area of the $\mathrm{H}$ cell. When in contact with the $\mathrm{H}$ glass the sensor read between 29 and $30^{\circ} \mathrm{C}$, while when in contact with the $\mathrm{D}$ glass the sensor read between 30 and $31{ }^{\circ} \mathrm{C}$, with occasional excursions up to $32{ }^{\circ} \mathrm{C}$. The $\mathrm{H}$ cell was at this point at $3.30 \mathrm{~V}$ with the $\mathrm{D}$ cell at only $2.84 \mathrm{~V}$. The experiment was switched off at 8:44 PM for the night.

FIG. 27: Power input versus temperature chart for the cells in the run of January 8, 2002.

Run of January 8, 2002. Duration: 647 minutes.

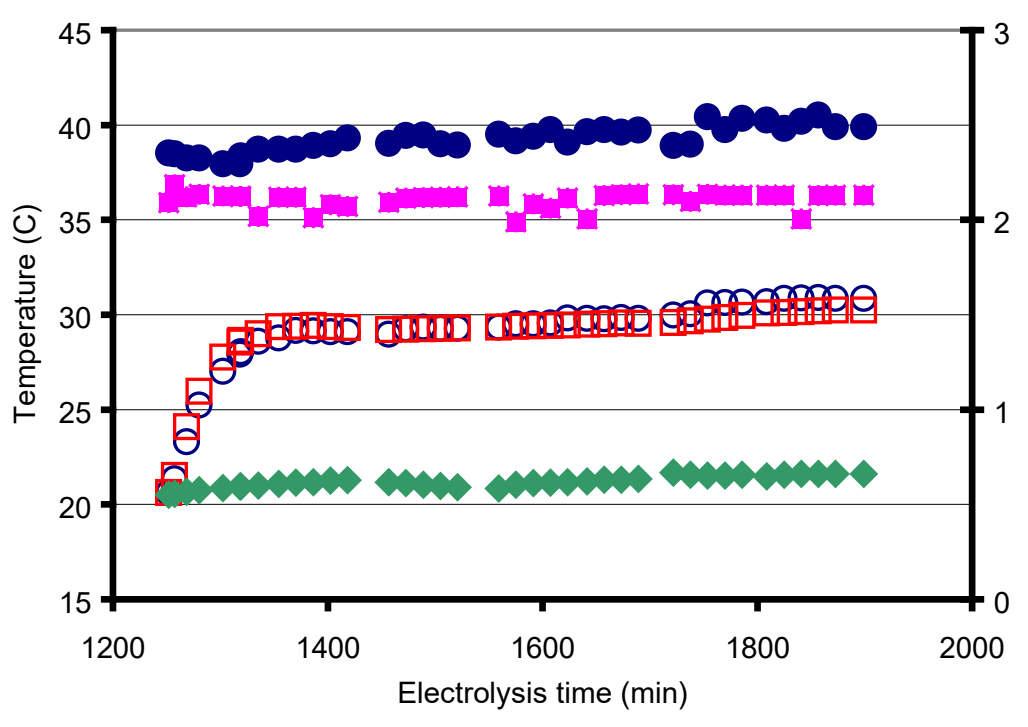

\begin{tabular}{|c|}
\hline $\begin{array}{c}\text { Cell } \\
\text { power } \\
\text { input } \\
\text { (watts) }\end{array}$ \\
\hline $\begin{array}{l}\text { OH cell temperature } \\
\text { (two thermocouple } \\
\text { average) }\end{array}$ \\
\hline $\begin{array}{l}\square \text { D cell temperature } \\
\text { (two thermocouple } \\
\text { average) }\end{array}$ \\
\hline $\begin{array}{l}\text { Ambient } \\
\text { temperature (CJC) }\end{array}$ \\
\hline Power into $\mathrm{H}$ cell \\
\hline Power into D cell \\
\hline
\end{tabular}




\section{-Run of January 9, 2002}

On January 92002 the circuit was switched on at 12:56 PM.

The two cells remained at the same temperature all afternoon with the $\mathrm{H}$ cell receiving 8-10\% more power. At around 5:42 PM the D cell seemed to slightly overtake the $\mathrm{H}$ cell in temperature.

At the end of the evening the bottom of the $\mathrm{H}$ cell was at $30.4{ }^{\circ} \mathrm{C}$ while the bottom of the D cell was at $30.6{ }^{\circ} \mathrm{C}$. The $\mathrm{H}$ cell was at $3.34 \mathrm{~V}$ while the $\mathrm{D}$ cell was at 2.90 V. The experiment was switched off at 8:33 PM for the night.

FIG. 28: Power input versus temperature chart for the cells in the run of January 9, 2002.

Run of January 9, 2002. Duration: 462 minutes.

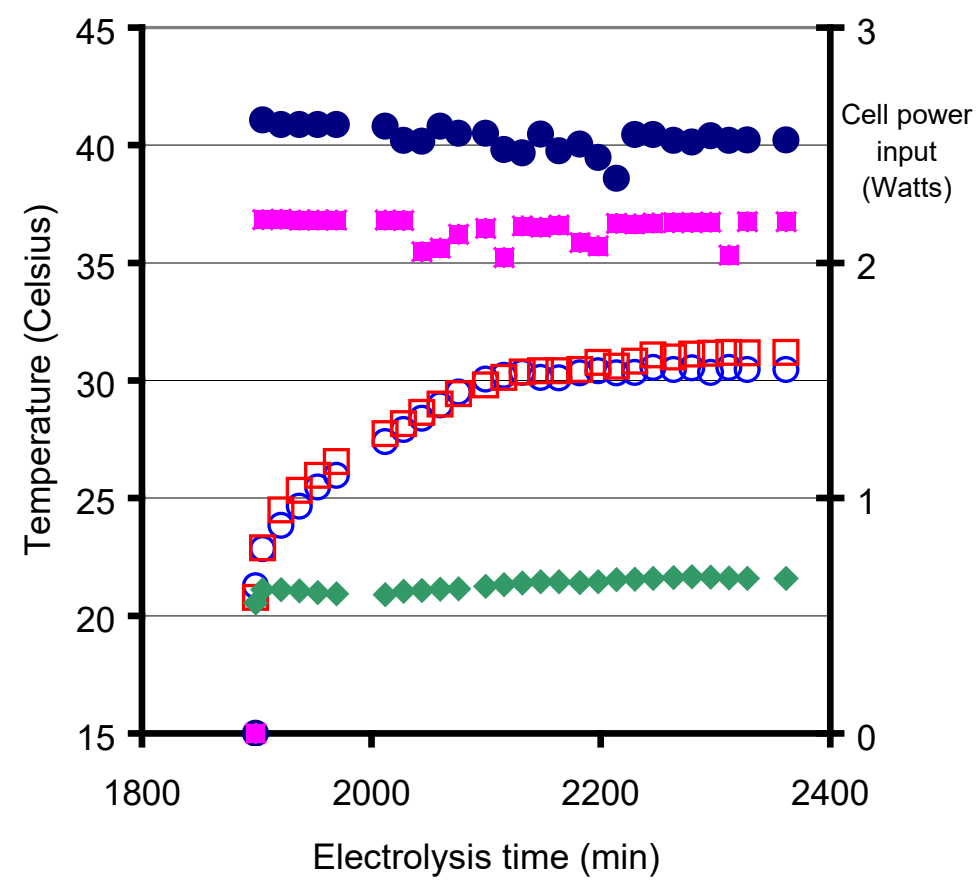

OH cell temperature (two thermocouple average)

口D cell temperature (two thermocouple average)

Ambient temperature (CJC)

- Power into $\mathrm{H}$ cell

- Power into D cell 


\section{-Run of January 10, 2002}

On the morning of January 10 2002, with the circuit having been off all night, the probes underneath the cells both read $20^{\circ} \mathrm{C}$. The mercury thermometer between the cells read $20.1^{\circ} \mathrm{C}$.

Current was switched on at 9:01 AM. The H cell seemed to warm up faster, but by 10:24 AM the D cell had according to the bottom sensor display already caught up with the $\mathrm{H}$ cell. At this point the $\mathrm{D}$ cell was at $2.94 \mathrm{~V}$ with the $\mathrm{H}$ cell at $3.27 \mathrm{~V}$. The HH 82 Digital sensor confirmed that the D cell was getting warmer, unmistakably displaying $28 / 29{ }^{\circ} \mathrm{C}$ for the back of the $\mathrm{H}$ cell in the area where the sensor's thermocouple was positioned, and $29 / 30{ }^{\circ} \mathrm{C}$ for the back of the $\mathrm{D}$ cell at approximately the same position. It was taking less time for the cells to reach the point at which the $\mathrm{D}$ began to overtake the $\mathrm{H}$.

By 12:22 PM the gap had already opened up to $0.3{ }^{\circ} \mathrm{C}$ in favor of the $\mathrm{D}$ cell. The $\mathrm{D}$ cell was receiving $8 \%$ less power.

The experiment was very promising and so at 12:26 PM the circuit was disconnected in order to re-hook the thermocouples to the board in single-ended mode, which the Keithley staff assured worked better.

In the single-ended mode, the positive leg of the thermocouple in each channel is hooked up to the channel pin while the negative leg of the thermocouple is hooked up to the Ground pin. 
FIG. 29: Power input versus temperature chart for the cells in the run of January 10, 2002.

Run of January 10, 2002. Duration: 205 minutes.

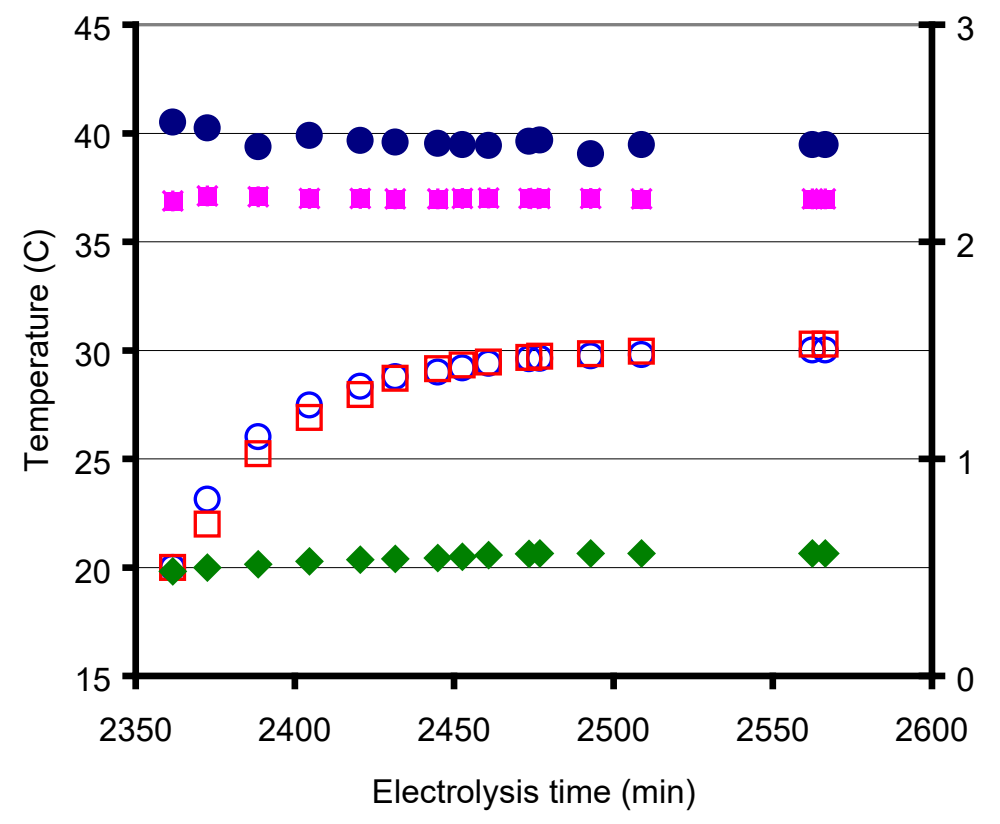

-Run of January 11, 2002

On January 112002 the circuit was switched on at 3 PM after the thermocouples had been successfully tested in the new mode. At 4:20 PM, the D cell was already surpassing the $\mathrm{H}$ cell: the thermocouples were registering $31.6{ }^{\circ} \mathrm{C}$ for the rear of the $\mathrm{H}$ cell and $31.9{ }^{\circ} \mathrm{C}$ for the rear of the $\mathrm{D}$ cell; $31.8{ }^{\circ} \mathrm{C}$ for the front of the $\mathrm{H}$ cell and $31.9{ }^{\circ} \mathrm{C}$ for the front of the $\mathrm{D}$ cell, with the probes at the bottom reading 29.4 ${ }^{\circ} \mathrm{C}$ for the $\mathrm{H}$ cell and $29.4{ }^{\circ} \mathrm{C}$ for the $\mathrm{D}$ cell, all after correcting for calibration. The D cell was at $2.94 \mathrm{~V}$ while the $\mathrm{H}$ cell was at $3.27 \mathrm{~V}$. 
The experiment was switched off at 6:52 PM for the night.

FIG. 30: Power input versus temperature chart for the cells in the run of January 11, 2002.

Run of January 11, 2002. Duration: 236 minutes.

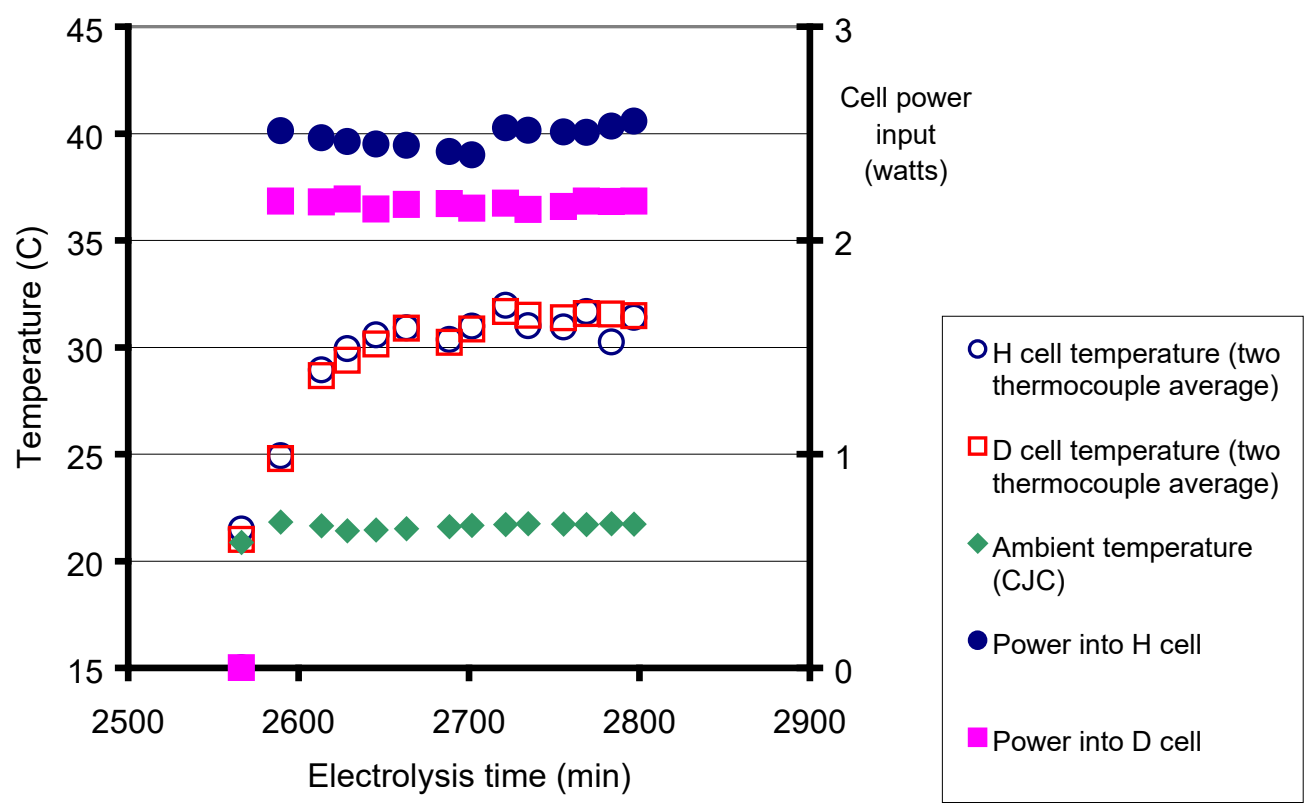

-Run of January 14, 2002

Shortly after switch-on at 9:57 AM on the following day, it was noticed that the cathode of the $\mathrm{H}$ cell was bending slightly towards the anode; the $\mathrm{D}$ cell cathode was bent back from the anode, subtending $\sim 30^{\circ}$ with the horizontal, and covered in the blackish powdery coating.

At 3:15 PM the digital thermometer whose sensor was affixed to the bottom of the D cell was displaying $28.8^{\circ} \mathrm{C}$ while the sensor that was affixed to the bottom of the 
$\mathrm{H}$ cell was displaying $28.7^{\circ} \mathrm{C}$. Applying the slightly different calibrations of the two digital thermometers, this meant that the bottom of the D cell was already leading the bottom of the $\mathrm{H}$ cell by $0.4{ }^{\circ} \mathrm{C}$. At this point the temperatures according to the thermocouples were $30.4{ }^{\circ} \mathrm{C}$ for the rear of the $\mathrm{H}$ cell and $32.1{ }^{\circ} \mathrm{C}$ for the rear of the $\mathrm{D}$ cell, $30.9{ }^{\circ} \mathrm{C}$ for the front of the $\mathrm{H}$ cell and $31.4{ }^{\circ} \mathrm{C}$ for the front of the $\mathrm{D}$ cell. The D cell was at only $3.05 \mathrm{~V}$ with the $\mathrm{H}$ cell at $3.28 \mathrm{~V}$.

For the rest of the day until 9:50 PM when the circuit was switched off the D cell remained at the same temperature as the $\mathrm{H}$ cell or slightly warmer, with the $\mathrm{H}$ cell at $3.30 \mathrm{~V}$ and the $\mathrm{D}$ cell at $3.04 \mathrm{~V}$.

FIG. 31: Power input versus temperature chart for the cells in the run of January 14, 2002.

Run of January 14, 2002. Duration: 722 minutes.

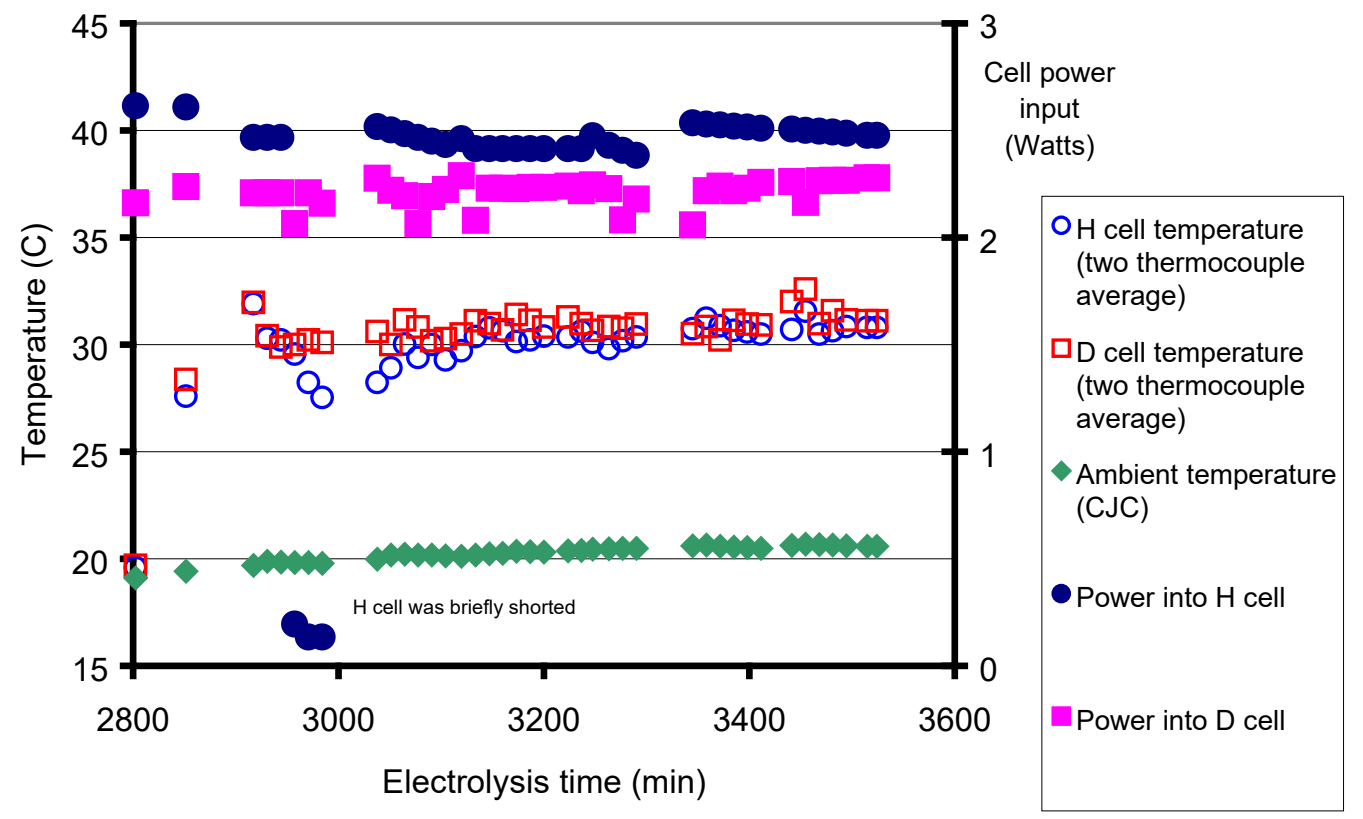




\section{-Run of January 15, 2002}

On January 15, 2002 the experiment continued.

At 11:49 in the morning, only $1 \mathrm{~h} 26^{\prime}$ after switch-on, the D cell temperature had already reached the $\mathrm{H}$ cell temperature and was rising. The $\mathrm{D}$ cell bottom was displaying $28.6{ }^{\circ} \mathrm{C}$ compared with the $\mathrm{H}$ cell bottom display of $28.1{ }^{\circ} \mathrm{C}$, and this without adjusting for the calibration correction. The thermocouples at this moment were reading $30.2{ }^{\circ} \mathrm{C}$ for the rear of the $\mathrm{H}$ cell and $31.5^{\circ} \mathrm{C}$ for the rear of the $\mathrm{D}$ cell, after adjusting for calibration. For the front of the cells the calibration-corrected temperatures were $29.5{ }^{\circ} \mathrm{C}$ for the $\mathrm{H}$ cell and $30.4{ }^{\circ} \mathrm{C}$ for the $\mathrm{D}$ cell. At this point the $\mathrm{H}$ cell was at $3.32 \mathrm{~V}$ with the $\mathrm{D}$ cell at only $3.07 \mathrm{~V}$.

This small but clear temperature elevation of the D cell seemed to be maintained over time.

At 1:11:45 PM the $\mathrm{H}$ cell bottom sensor was displaying $29^{\circ} \mathrm{C}$ while the $\mathrm{D}$ cell bottom sensor was displaying $29.4{ }^{\circ} \mathrm{C}$. The $\mathrm{H}$ cell voltage was $3.34 \mathrm{~V}$ while the $\mathrm{D}$ cell voltage was $3.08 \mathrm{~V}$.

At $2 \mathrm{PM}$ the front of the $\mathrm{H}$ cell was at $31.6{ }^{\circ} \mathrm{C}$ while the front of the $\mathrm{D}$ cell was at $32{ }^{\circ} \mathrm{C}$. The back of the $\mathrm{H}$ cell was at $31.4{ }^{\circ} \mathrm{C}$ while the back of the $\mathrm{D}$ cell was at $32.9{ }^{\circ} \mathrm{C}$. The bottom of the $\mathrm{D}$ cell was $0.6^{\circ} \mathrm{C}$ warmer than the bottom of the $\mathrm{H}$ cell, after correcting for calibration. The $\mathrm{H}$ cell required $3.33 \mathrm{~V}$ while the $\mathrm{D}$ cell required only $3.07 \mathrm{~V}$. 
At 4:09:51 PM the D cell was still leading the $\mathrm{H}$ cell by $0.6{ }^{\circ} \mathrm{C}$. At this moment the thermocouples were registering $31.7{ }^{\circ} \mathrm{C}$ for the rear of the $\mathrm{H}$ cell and $32.8{ }^{\circ} \mathrm{C}$ for the rear of the D cell; $30.8{ }^{\circ} \mathrm{C}$ for the front of the $\mathrm{H}$ cell and $31.7{ }^{\circ} \mathrm{C}$ for the front of the D cell, after adjusting for calibration.

At 4:33 PM the probe underneath the $\mathrm{H}$ cell was displaying $29.8{ }^{\circ} \mathrm{C}$ while the probe underneath the $\mathrm{D}$ cell was displaying $30.2^{\circ} \mathrm{C}$. The thermocouples were registering $31.9{ }^{\circ} \mathrm{C}$ for the back of the $\mathrm{H}$ cell and $33.4{ }^{\circ} \mathrm{C}$ for the back of the $\mathrm{D}$ cell; $30.7{ }^{\circ} \mathrm{C}$ for the front of the $\mathrm{H}$ cell and $31.9{ }^{\circ} \mathrm{C}$ for the front of the $\mathrm{D}$ cell after correcting for calibration. The $\mathrm{H}$ cell was at $3.32 \mathrm{~V}$ with the D cell at only $3.09 \mathrm{~V}$.

An independent confirmation was needed and hence use was made again of the $\mathrm{HH}$ 82 digital sensor, which on its screen displayed $30{ }^{\circ} \mathrm{C}$ directly underneath the $\mathrm{H}$ cell and $30.2{ }^{\circ} \mathrm{C}$ under the $\mathrm{D}$ cell in the same position. At this instant the $\mathrm{H}$ cell was at $3.36 \mathrm{~V}$ with the $\mathrm{D}$ cell at only $3.10 \mathrm{~V}$.

At 8:36 PM the $\mathrm{H}$ cell was receiving $3.45 \mathrm{~V}$ and was at $30.4{ }^{\circ} \mathrm{C}$ at its bottom; the $\mathrm{D}$ cell was receiving $3.12 \mathrm{~V}$ and was at $31.1{ }^{\circ} \mathrm{C}$ at its bottom.

The experiment was switched off at 10:18 PM. 
FIG. 32: Power input versus temperature chart for the cells in the run of January 15, 2002.

Run of January 15, 2002. Duration: 715 minutes.

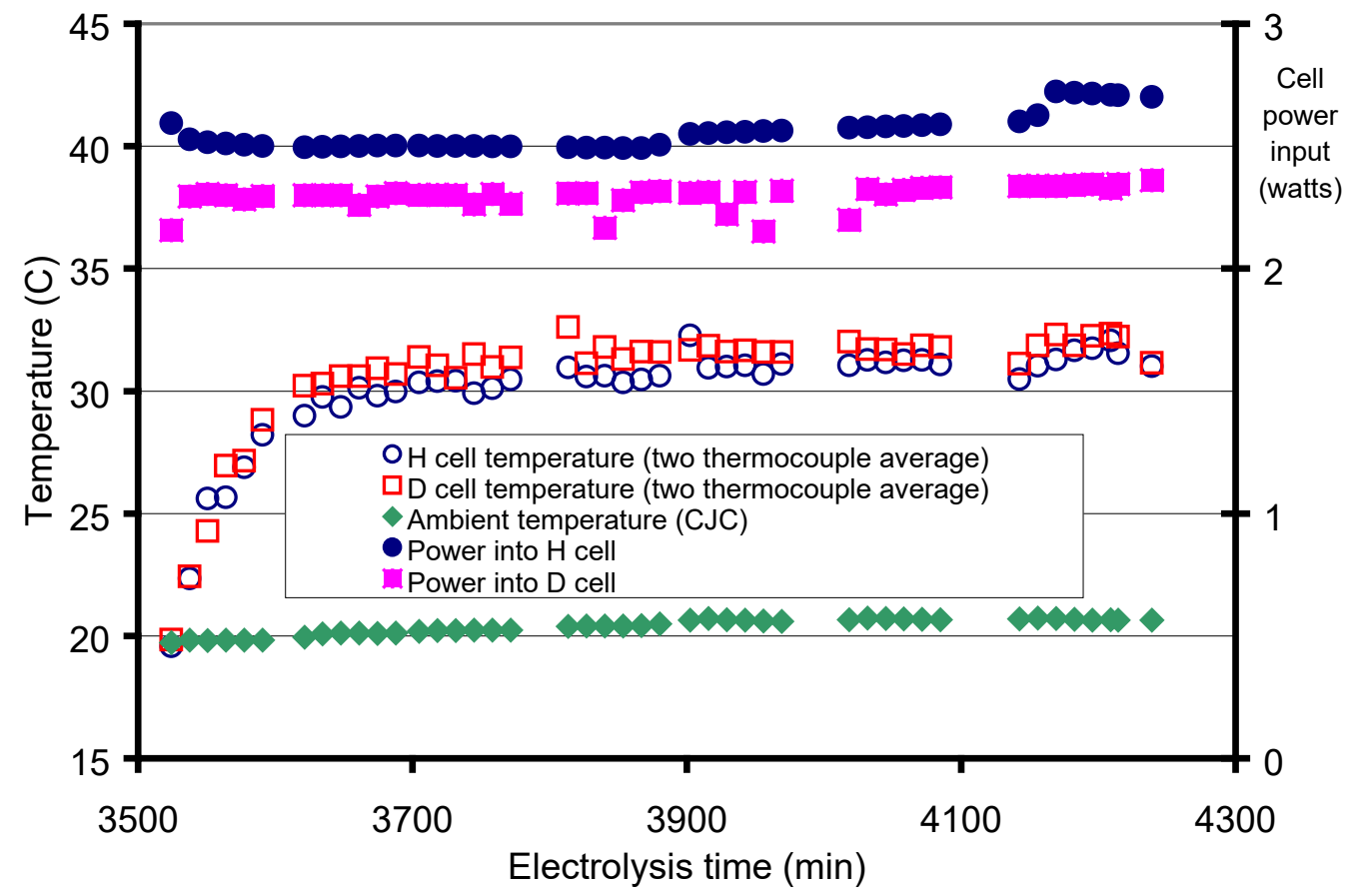

-Run of January 16, 2002

The circuit was switched on at 10:08 AM on January 16 2002: within 16 minutes the $\mathrm{D}$ cell temperature had already surpassed the $\mathrm{H}$ cell temperature, the $\mathrm{H}$ bottom was at $29.7{ }^{\circ} \mathrm{C}$ while the $\mathrm{D}$ cell bottom was already at $30.4{ }^{\circ} \mathrm{C}$. At this point the $\mathrm{H}$ cell was at $3.68 \mathrm{~V}$ with the $\mathrm{D}$ cell at $3.48 \mathrm{~V}$.

At noon the bottom of the $\mathrm{H}$ cell, which was at a voltage $0.33 \mathrm{~V}$ higher than the $\mathrm{D}$ cell, was already trailing a full $0.7{ }^{\circ} \mathrm{C}$ behind the bottom of the $\mathrm{D}$ cell. 
At 2:57 PM the bottom of the $\mathrm{H}$ cell was at $31.3{ }^{\circ} \mathrm{C}$ while the probe at the bottom of the $\mathrm{D}$ cell was at $31.8^{\circ} \mathrm{C}$. The $\mathrm{H}$ cell at this point was at $3.56 \mathrm{~V}$ with the $\mathrm{D}$ cell at only $3.23 \mathrm{~V}$.

At 4:06 PM the temperature gap between the two cells had increased. The bottom of the $\mathrm{H}$ cell was at $31.2{ }^{\circ} \mathrm{C}$ while the bottom of the $\mathrm{D}$ cell was at $32.1{ }^{\circ} \mathrm{C}$. The $\mathrm{H}$ cell was at $3.55 \mathrm{~V}$ while the $\mathrm{D}$ cell was at only $3.31 \mathrm{~V}$. In search of possible artifacts that could detract from these remarkable results, the positioning of the thermocouples was inspected more closely. It was the same for both cells.

At 4:29 PM the temperature gap had stabilized. The Radioshack digital thermometers sensors were displaying $31.2{ }^{\circ} \mathrm{C}$ for the bottom of the $\mathrm{H}$ cell and 31.9 ${ }^{\circ} \mathrm{C}$ for the bottom of the $\mathrm{D}$ cell. At this point the $\mathrm{D}$ cell was at $3.31 \mathrm{~V}$ while the $\mathrm{H}$ cell was at $3.52 \mathrm{~V}$.

For the subsequent three hours the bottom of the D cell continued leading the bottom of the $\mathrm{H}$ cell by $0.6{ }^{\circ} \mathrm{C}$ with the $\mathrm{D}$ cell at a voltage $0.2 \mathrm{~V}$ lower than the $\mathrm{H}$ cell. 
FIG. 33: Power input versus temperature chart for the cells in the run of January 16, 2002.

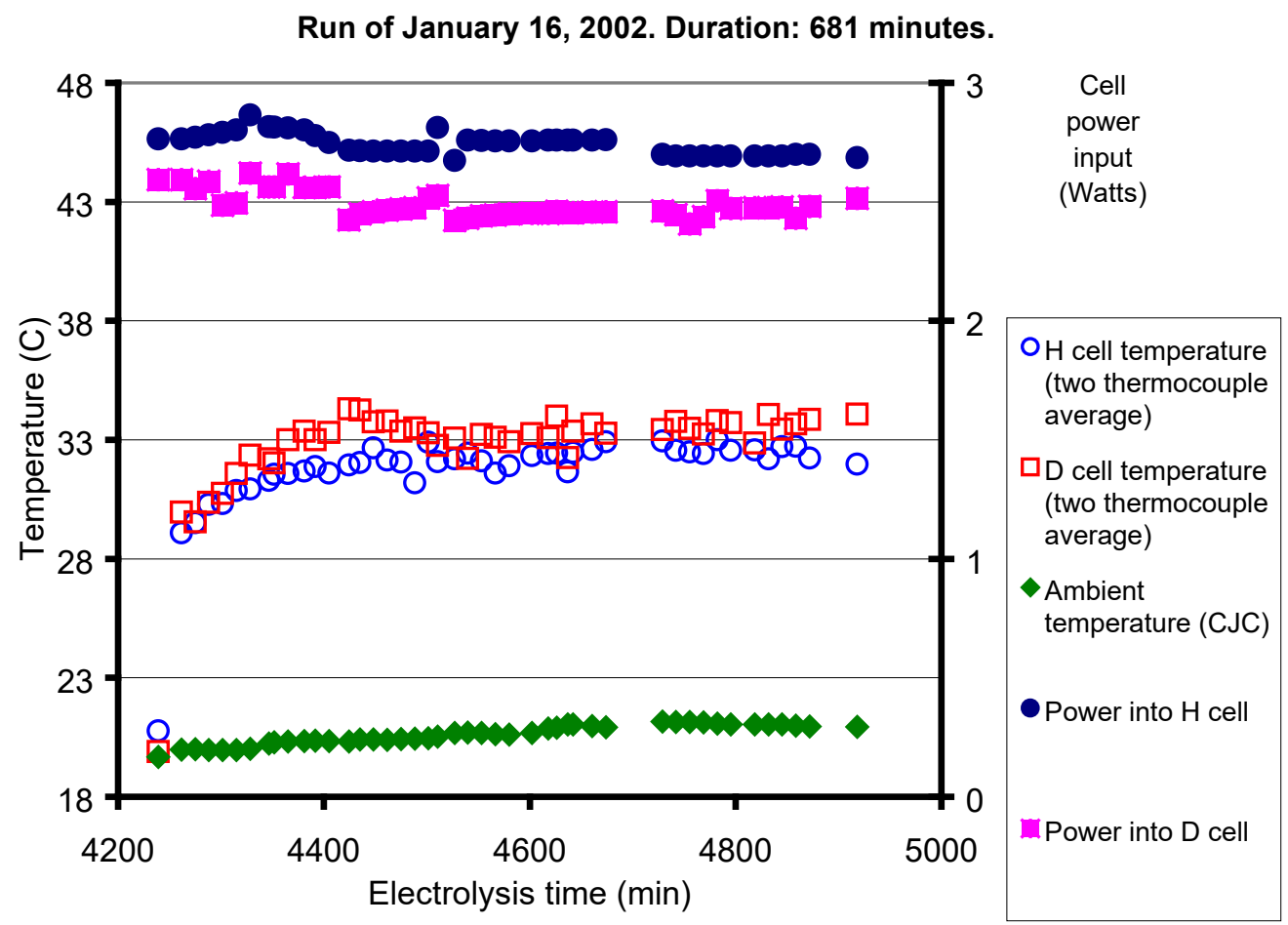

The experiment was switched off at 9:30 PM for the night. Upon switch-off, the bottom of the $\mathrm{D}$ cell was at $32.8{ }^{\circ} \mathrm{C}$ while the bottom of the $\mathrm{H}$ cell was at $32{ }^{\circ} \mathrm{C}$, and the $\mathrm{D}$ cell was at $3.35 \mathrm{~V}, 0.23 \mathrm{~V}$ less than the $\mathrm{H}$ cell. The blackish material in the D cell electrolyte had now dissolved into particles, forming a deposit around the cathode.

-Run of January 172002

On January 17, 2002, power was switched on at 9:55 AM. 
At 10:57 AM, the $\mathrm{H}$ cell bottom sensor was displaying $30.3{ }^{\circ} \mathrm{C}$ and the $\mathrm{D}$ cell bottom sensor was displaying $30.6{ }^{\circ} \mathrm{C}$, with the voltages essentially unmoved, 3.61 $\mathrm{V}$ for the $\mathrm{H}$ cell and $3.40 \mathrm{~V}$ for the $\mathrm{D}$. A double-check was then conducted to confirm these readings. Were the cells still properly aligned? Were the bottom sensors still in the same positions relative to the electrodes? Had a sudden temperature gradient been introduced in the room? These questions had to be asked constantly.

The next thermocouple pass returned $29.6{ }^{\circ} \mathrm{C}$ for the back of the $\mathrm{H}$ cell and $32.2{ }^{\circ} \mathrm{C}$ for the back of the $\mathrm{D}$ cell; $30.3{ }^{\circ} \mathrm{C}$ for the front of the $\mathrm{H}$ cell and $31.5^{\circ} \mathrm{C}$ for the front of the D cell, after correcting for calibration.

At 11:10 AM, 1h 15 minutes into the run, the digital display for the D cell bottom was $31.3{ }^{\circ} \mathrm{C}$ while the digital display for the $\mathrm{H}$ cell bottom was $30.6{ }^{\circ} \mathrm{C}$. That meant that the $\mathrm{D}$ cell was more than $0.9{ }^{\circ} \mathrm{C}$ warmer than the $\mathrm{H}$ cell after bearing in mind the slightly different calibrations of both digital thermometers. The voltage was about $0.19 \mathrm{~V}$ greater for the $\mathrm{H}$ cell. The bulb midway between the cells was reading the same ambient temperature as the CJC: $\sim 20.6^{\circ} \mathrm{C}$. So there could be no crossover effect of one cell receiving more heat than the other. In fact if there was any such effect it would only tend to equalize the temperatures of the cells and hence take away from whatever temperature gap one could open on the other.

In the next temperature check, at 11:12 AM, the $\mathrm{H}$ cell bottom sensor was displaying $30.7^{\circ} \mathrm{C}$, and the $\mathrm{D}$ cell bottom sensor was displaying $31.4^{\circ} \mathrm{C}$. 
In the next manual temperature check, at 11:31 AM, the probe at the bottom of the $\mathrm{H}$ cell bottom was displaying $30.9^{\circ} \mathrm{C}$, while the probe at the bottom of the $\mathrm{D}$ cell was displaying $32{ }^{\circ} \mathrm{C}$. The voltage of the $\mathrm{H}$ cell at this point was $3.58 \mathrm{~V}$, while the D cell voltage was $3.39 \mathrm{~V}$. The next (calibration-corrected) thermocouple return was $29.1{ }^{\circ} \mathrm{C}$ for the rear of the $\mathrm{H}$ cell and $32.7{ }^{\circ} \mathrm{C}$ for the rear of the $\mathrm{D}$ cell; $31.2{ }^{\circ} \mathrm{C}$ for the front of the $\mathrm{H}$ cell and $31.5{ }^{\circ} \mathrm{C}$ for the front of the $\mathrm{D}$ cell.

At the end of the run, at 9:51 PM, the $\mathrm{H}$ cell bottom display was $31.9{ }^{\circ} \mathrm{C}$ while the $\mathrm{D}$ cell bottom display was $33.2^{\circ} \mathrm{C}$. At that point, the voltage of the $\mathrm{H}$ cell was 3.54 $\mathrm{V}$ and the voltage of the $\mathrm{D}$ cell was $3.36 \mathrm{~V}$. The experiment was switched off at 9:53 PM for the night.

FIG. 34: Power input versus temperature chart for the cells in the run of January 17, 2002.

Run of January 17, 2002. Duration: 718 minutes.

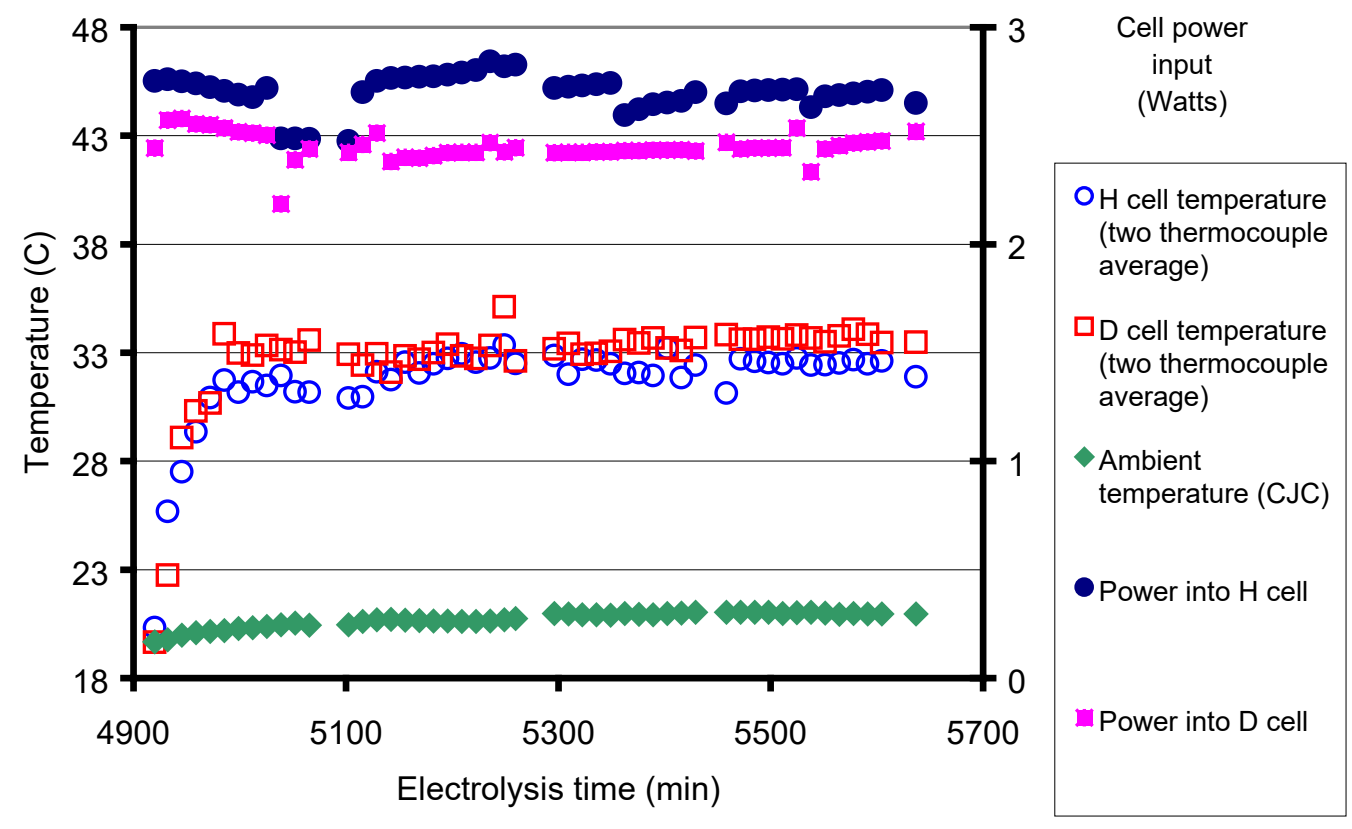




\section{-Run of January 18, 2002}

On Friday January 18 2002, the current was switched on at 9:21 in the morning.

At 12:12 PM the voltage of the $\mathrm{D}$ cell was $3.52 \mathrm{~V}$ and the voltage of the $\mathrm{H}$ cell was 3.69 V. The bottom digital sensor displays were $31.9^{\circ} \mathrm{C}$ for the $\mathrm{H}$ cell and $33.8{ }^{\circ} \mathrm{C}$ for the $\mathrm{D}$ cell. That was a $1.9^{\circ} \mathrm{C}$ lead which after adjusting for the slightly different calibration of the two digital thermometer sensors was actually $2.2{ }^{\circ} \mathrm{C}$.

At 3:04 PM the voltage of the $\mathrm{H}$ cell was stable at $3.75 \mathrm{~V}$ and the voltage of the $\mathrm{D}$ cell was stable at $3.50 \mathrm{~V}$. The bottom sensor digital displays were $32.5^{\circ} \mathrm{C}(\mathrm{H}$ cell $)$ and $33.7^{\circ} \mathrm{C}$ (D cell).

At 3:53 PM the $\mathrm{H}$ cell was at $3.73 \mathrm{~V}$ and the $\mathrm{D}$ cell was at $3.51 \mathrm{~V}$. The bottom sensor digital display was $32.6^{\circ} \mathrm{C}$ for the $\mathrm{H}$ cell and $34.1{ }^{\circ} \mathrm{C}$ for the $\mathrm{D}$ cell.

At 4:33 PM the voltages were $3.71 \mathrm{~V}$ (H cell) and $3.51 \mathrm{~V}$ (D cell), and the bottom sensor digital displays were $32.7^{\circ} \mathrm{C}$ for the $\mathrm{H}$ cell and $34.2{ }^{\circ} \mathrm{C}$ for the $\mathrm{D}$ cell.

At 9:06:58 PM, just before switch-off, the voltages were $3.72 \mathrm{~V}(\mathrm{H}$ cell) and $3.50 \mathrm{~V}$ (D cell). The bottom sensor digital displays were $32.6{ }^{\circ} \mathrm{C}$ for the $\mathrm{H}$ cell and $34.2{ }^{\circ} \mathrm{C}$ for the D cell. 
FIG. 35: Power input versus temperature chart for the cells in the run of January 18, 2002.

Run of January 18, 2002. Duration: 708 minutes.

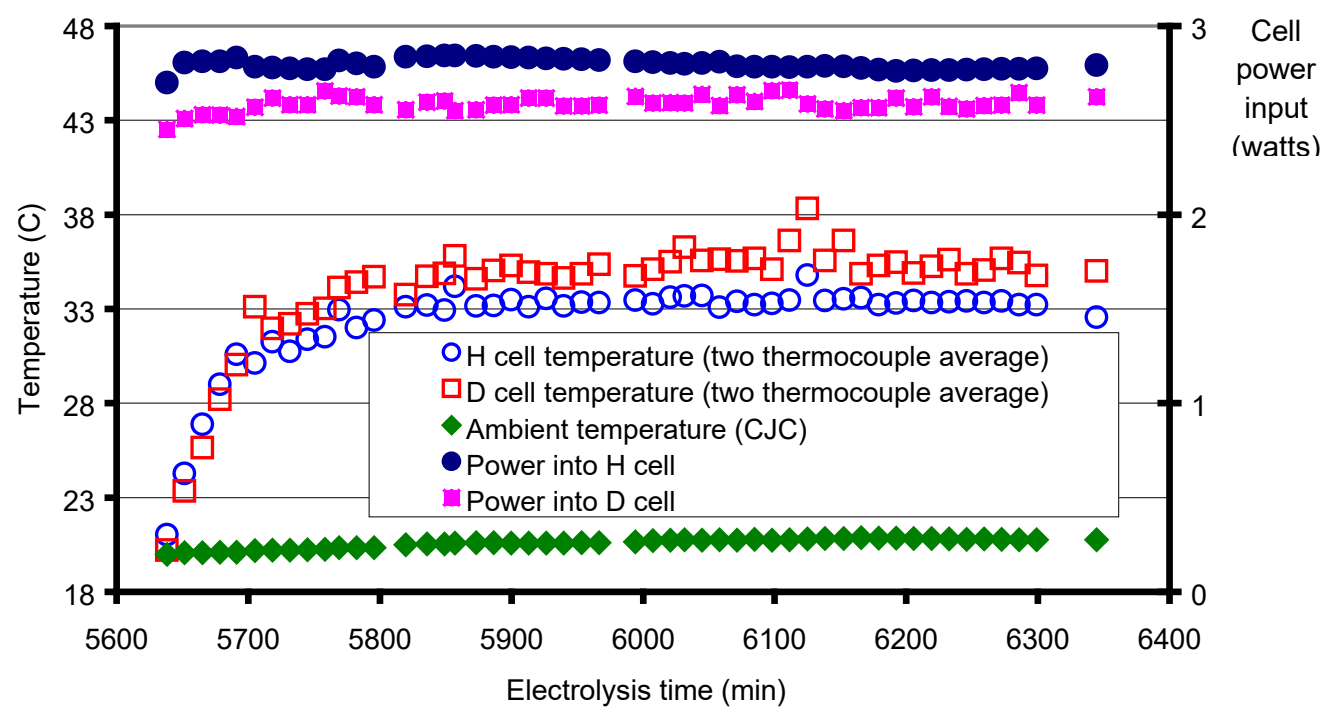

-Run of January 222002

On Tuesday January 222002 the experiment was resumed at 10:10 AM.

At 10:55 AM the bottom sensor digital displays for both cells were $29.4^{\circ} \mathrm{C}$. At that point the voltage of the $\mathrm{H}$ cell was $3.72 \mathrm{~V}$ and the voltage of the $\mathrm{D}$ cell was $3.49 \mathrm{~V}$.

At 1:21 PM the $\mathrm{H}$ cell was at $3.81 \mathrm{~V}$ while the $\mathrm{D}$ cell was at $3.45 \mathrm{~V}$. This still did not preclude the bottom digital sensors from displaying a temperature $1.1^{\circ} \mathrm{C}$ higher for the $\mathrm{D}$ cell than for the $\mathrm{H}$ : the $\mathrm{D}$ cell bottom was displaying $33.6^{\circ} \mathrm{C}$ while the $\mathrm{H}$ cell bottom was displaying $32.5^{\circ} \mathrm{C}$. After correcting for calibration, the gap was 1.4 ${ }^{\circ} \mathrm{C}$. 
At 4:08 PM the $\mathrm{H}$ cell was at $3.79 \mathrm{~V}$ and the $\mathrm{D}$ cell was at $3.45 \mathrm{~V}$. The digital display was $32.7{ }^{\circ} \mathrm{C}$ for the bottom of the $\mathrm{H}$ cell and $34.1{ }^{\circ} \mathrm{C}$ for the bottom of the $\mathrm{D}$ cell. The experiment was finally switched off at 4:10 PM.

FIG. 36: Power input versus temperature chart for the cells in the run of January 22, 2002.

Run of January 22, 2002. Duration: 361 minutes.
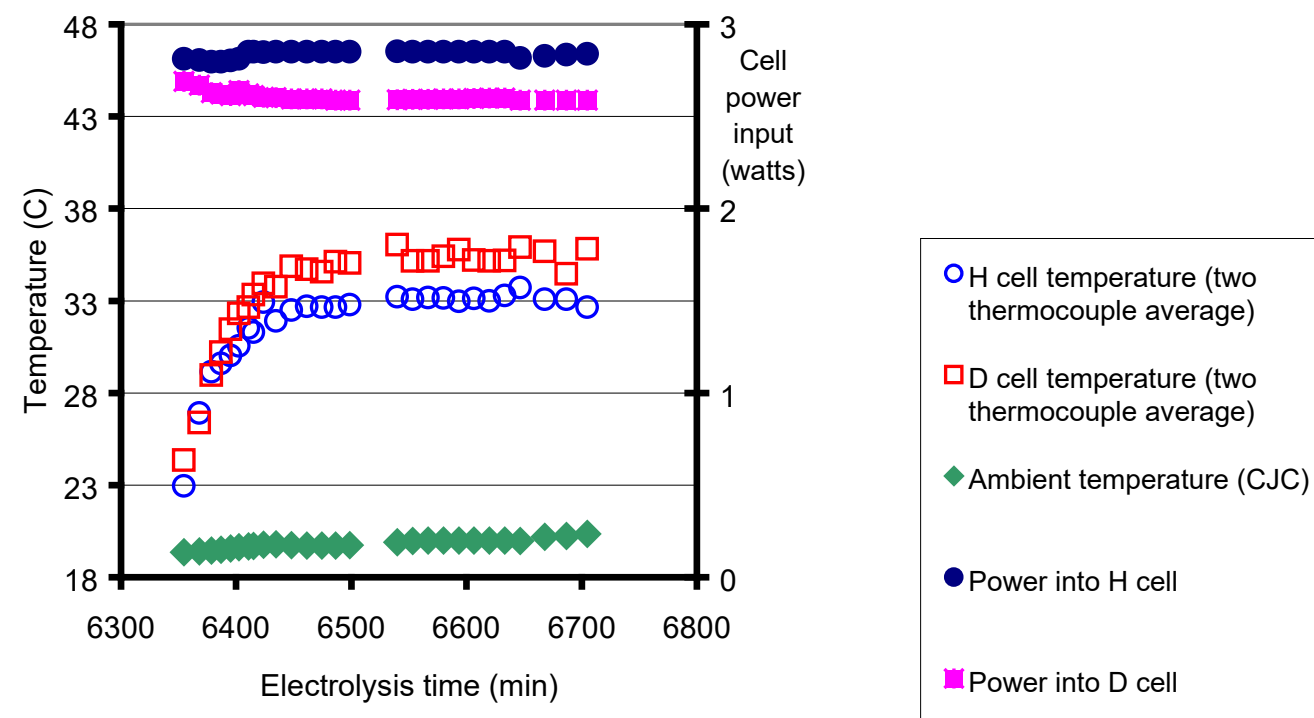

Two more thermocouples were then added to each cell, one to monitor the temperature at the bottom, to replace the Radioshack digital sensor, and another to monitor the temperature at the top.

\section{- Run of January 232002}

With the new thermocouples in place the circuit was switched on the next morning at 10:06 AM, with the $\mathrm{H}$ cell potential at $3.25 \mathrm{~V}$ and the $\mathrm{D}$ cell potential at $3.25 \mathrm{~V}$. 
At 2:48 PM, the calibration-corrected returns were $29.5^{\circ} \mathrm{C}$ for the back of the $\mathrm{H}$ cell and $34.1{ }^{\circ} \mathrm{C}$ for the back of the D cell.

The D cell was getting warmer, and yet was receiving $8 \%$ less power.

At 7:35 PM the HH-82 sensor displayed, right on the front of the $\mathrm{H}$ cell, 30.4/30.5 ${ }^{\circ} \mathrm{C}$; and, immediately after, a similar spot on the front of the D cell made the HH-82 sensor read $33.6 / 33.7^{\circ} \mathrm{C}$.

At 8:50 PM, the $\mathrm{H}$ cell was at $3.71 \mathrm{~V}$ and the $\mathrm{D}$ cell at $3.37 \mathrm{~V}$. According to the thermocouple passes, the back of the $\mathrm{H}$ cell was at that point at $32.7^{\circ} \mathrm{C}$ while the back of the $\mathrm{D}$ cell was at $35.8{ }^{\circ} \mathrm{C}$.

The last thermocouple return of the day gave, after correcting for calibration, 32.6 ${ }^{\circ} \mathrm{C}$ for the rear of the $\mathrm{H}$ cell and $35.6{ }^{\circ} \mathrm{C}$ for the rear of the $\mathrm{D}$ cell.

The experiment was switched off at 9:54 PM.

The electrolyte of the D cell had a black-yellowish tinge.

The electrolyte of the $\mathrm{H}$ cell was clear and transparent. 
FIG. 37: Power input versus temperature chart for the cells in the run of January 23, 2002.

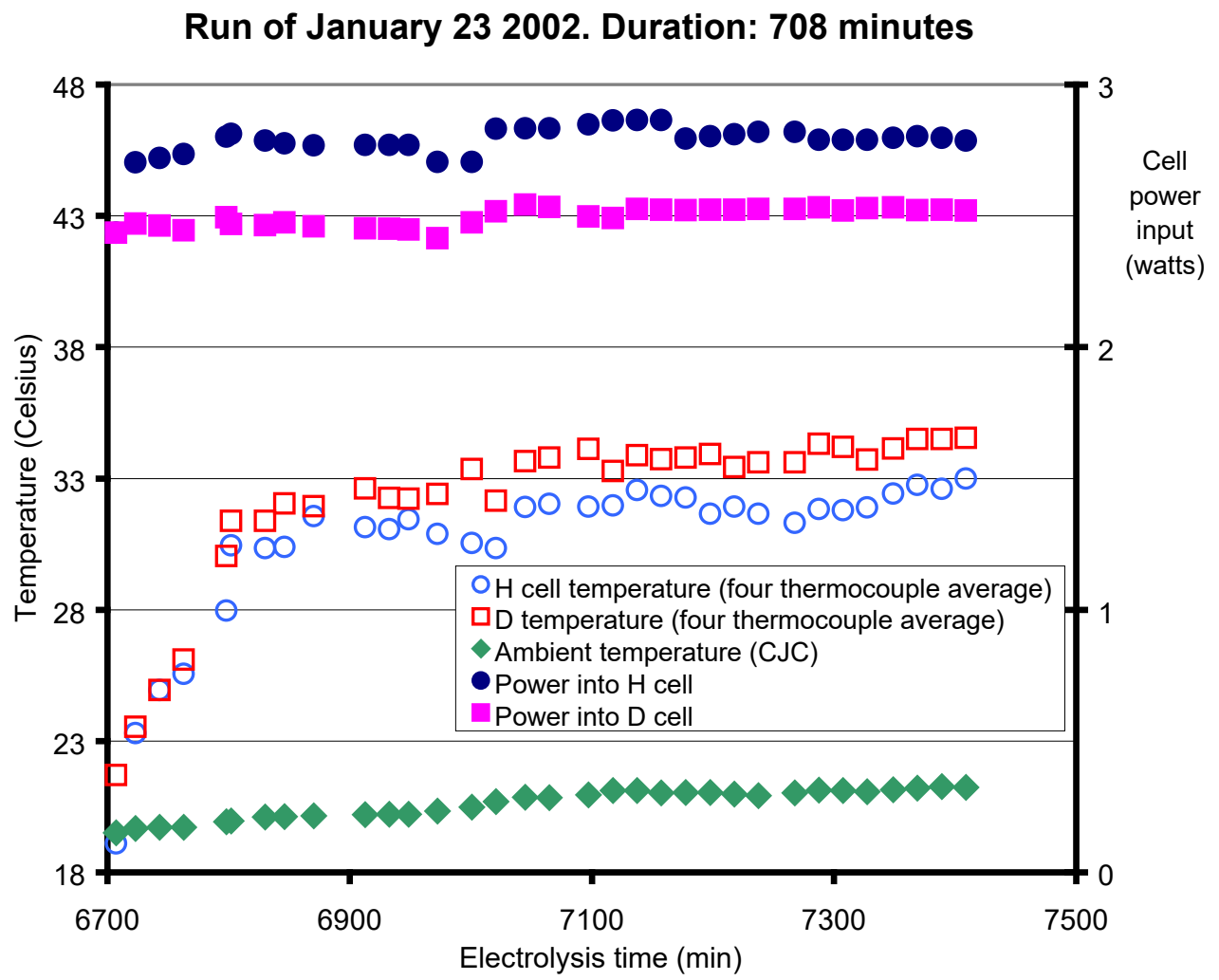

-Run of January 242002

On the last day that this experiment was conducted, January 24, 2002, current was switched on at 9:45 in the morning. The voltage was adjusted to $3.89 \mathrm{~V}$ for the $\mathrm{H}$ cell and $3.51 \mathrm{~V}$ for the $\mathrm{D}$ cell.

At 12:08 PM the $\mathrm{H}$ cell was at $3.75 \mathrm{~V}$ and the $\mathrm{D}$ cell was at $3.37 \mathrm{~V}$. After correcting for calibration, the rear of the $\mathrm{H}$ cell was at $30.7{ }^{\circ} \mathrm{C}$ while the rear of the 
D cell was at $33.5{ }^{\circ} \mathrm{C}$. The front of the $\mathrm{H}$ cell was at $30.3{ }^{\circ} \mathrm{C}$ while the front of the D cell was at $33.4{ }^{\circ} \mathrm{C}$.

At 12:25 PM the HH-82 sensor was displaying $35^{\circ} \mathrm{C}$ for both cells. According to the computer-connected thermocouples, the $\mathrm{H}$ cell bottom was at $32.4{ }^{\circ} \mathrm{C}$ and the $\mathrm{D}$ cell bottom was at $33.9{ }^{\circ} \mathrm{C}$. At this point the $\mathrm{H}$ cell was at $3.78 \mathrm{~V}$ while the $\mathrm{D}$ cell was at only $3.31 \mathrm{~V}$.

At 1:33 PM the $\mathrm{H}$ cell voltage was $3.69 \mathrm{~V}$ while the $\mathrm{D}$ cell voltage was $3.34 \mathrm{~V}$. The $\mathrm{H}$ cell bottom was at $33.9{ }^{\circ} \mathrm{C}$ while the $\mathrm{D}$ cell bottom was at $34.7{ }^{\circ} \mathrm{C}$. The data acquisition was aborted momentarily.

FIG. 38: Power input versus temperature chart for the cells in the first run of January 24, 2002.

January 24 2002. 1st run: 274 minutes
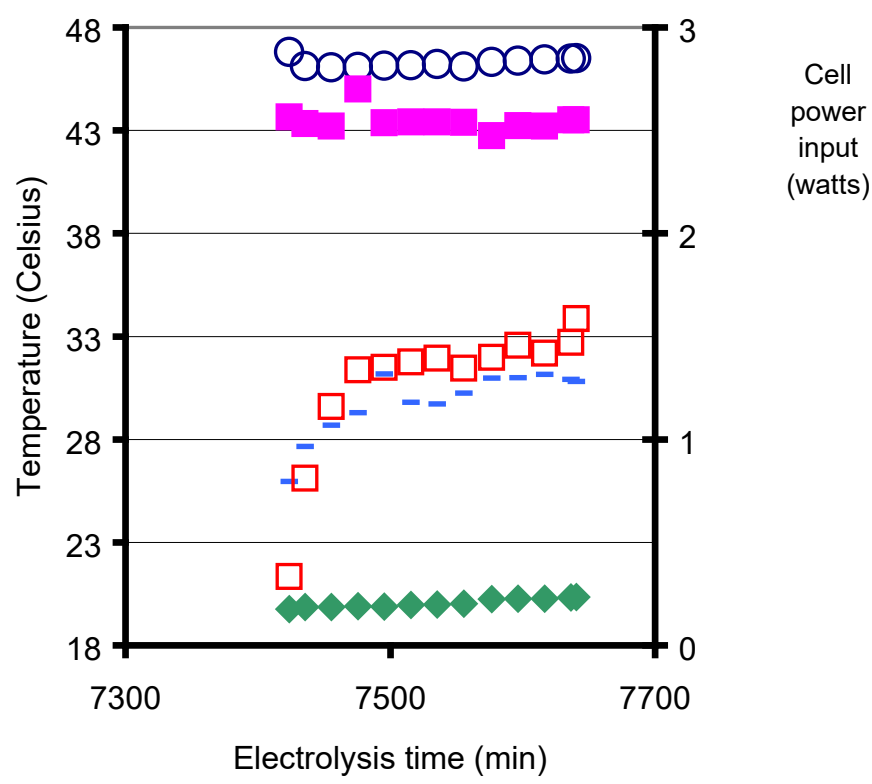

- H cell temperature (four thermocouple average)

$\square \mathrm{D}$ temperature (four thermocouple average)

$\checkmark$ Ambient temperature (CJC)

O Power into $\mathrm{H}$ cell

Power into D cell 
The experiment was resumed at 3:19 PM.

At 3:46 PM the HH-82 sensor displayed $32.9{ }^{\circ} \mathrm{C}$ for the $\mathrm{H}$ cell and $33.5^{\circ} \mathrm{C}$ for the $\mathrm{D}$ cell in the same position, with the $\mathrm{H}$ cell at $3.82 \mathrm{~V}$ and the $\mathrm{D}$ cell at $3.52 \mathrm{~V}$. The $\mathrm{H}$ cell reading was confirmed one more time right after the $\mathrm{D}$ cell reading.

The experiment was finally switched off at 6:07 PM. The last thermocouple pass gave, after correcting for calibration, $33.6{ }^{\circ} \mathrm{C}$ for the rear of the $\mathrm{H}$ cell and $36.4{ }^{\circ} \mathrm{C}$ for the rear of the $\mathrm{D}$ cell. The $\mathrm{H}$ cell had closed this last run at $3.83 \mathrm{~V}$ and the $\mathrm{D}$ cell at $3.52 \mathrm{~V}$.

FIG. 39: Power input versus temperature chart for the cells in the $2^{\text {nd }}$ run of January 24 , 2002

January 24 2002. 2nd run: 169 minutes

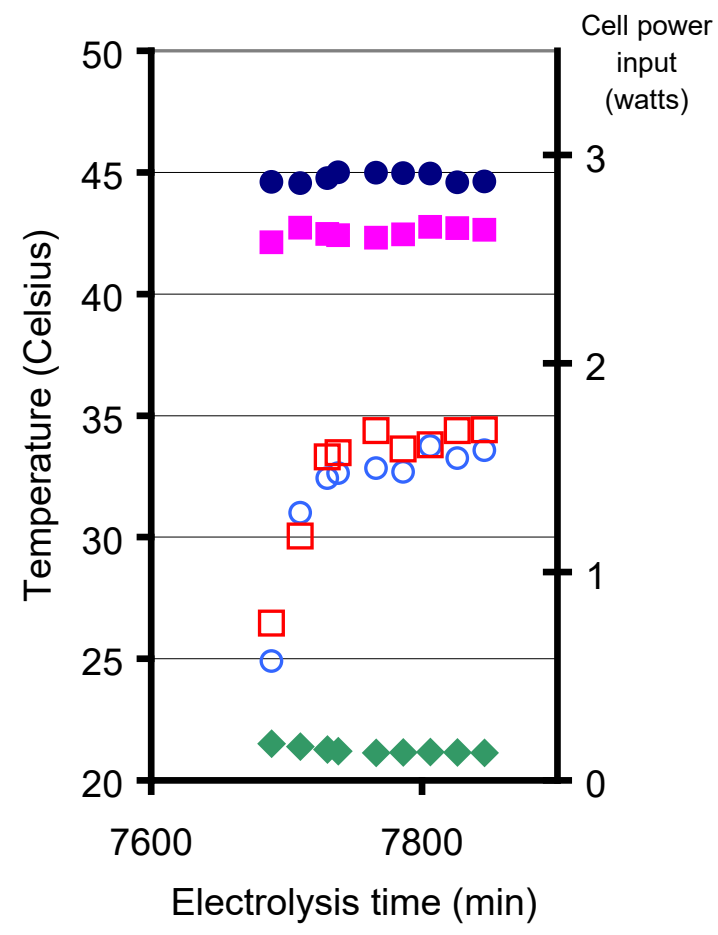

O H temperature (four thermocouple average)

$\square \mathrm{D}$ temperature (four thermocouple average)

Ambient temperature (CJC)

Power into $\mathrm{H}$ cell

Power into D cell 
On January 25, 2002, the two cells were removed from the circuit and weighed. The $\mathrm{H}$ cell had lost 38.07 grams (2.11 moles of $\mathrm{H}_{2} \mathrm{O}$ ) and the $\mathrm{D}$ cell had lost 30.02 grams $\left(1.50\right.$ moles of $\left.\mathrm{D}_{2} \mathrm{O}\right)$ in the 41461 minutes since the previous weighing. The actual time of electrolysis during this period had been 7666 minutes.

The cells were carefully examined. The anode of the $\mathrm{H}$ cell was bent against the cell floor, subtending an angle of only $\sim 45^{\circ}$ from the electrolyte surface so that the horizontal separation between the anode and the cathode diminished as one descended towards the bottom of the cell. The cathode of the H cell was in apparent good shape in its water-droplet-covered teflon sheathing, not splattered with any substance, and only slightly curved. The height of the electrolyte had dropped down to $12 \mathrm{~mm}$ from the initial 27 at the start of the experiment and the electrolyte looked very transparent and clear.

The D cell was much more interesting. The anode and cathode were very close to each other. Towards the end of the experiment increasing care had been needed with the D electrode fine-power adjustments, as the slightest mishap easily put the two electrodes in contact with each other, due to all the conducting blackish plates that were floating around the cathode. The anode was curled up on itself into a little roll due to repeated bending during power adjustments. The D cathode was severely curved (its lower tip in the electrolyte was arched $\sim 30^{\circ}$ from the vertical) and thickly buried in the black, powdery substance. It was the substance that had been produced in the first run of the experiment, in which the D cell had been 
run with reversed polarity by mistake. The droplet-covered teflon ring that had been wrapped around the two electrode wires had slid down from the teflon column to almost come to touch the electrodes themselves.

The cells were then taken apart for examination and the electrolyte was put away in a vial.

\section{APPENDIX D: ADDITIONAL SPECTRA FROM UNELECTROLYZED PALLADIUM.}

High apparent percentages of oxygen had been found on the spectrum of FIG. 6 from the $2.3 \mathrm{~mm} \times 2.3 \mathrm{~mm}$ selected area of unelectrolyzed cold-rolled palladium. SEMQuant processes X-ray spectra by automatic deconvolutions, and hence can easily misinterpret the concentration of very low-Z elements. Still, there was oxygen clearly trapped in the sample or bonded in the form of a thin surface layer of oxide.

There were also traces of platinum and sulfur (which most likely had resisted cleaning after having been picked from the cold-roll, where platinum and other samples are cold-worked all the time), small amounts of copper from the brass stage in the microscope chamber, and the palladium. The important thing was that there was no silver or cadmium in this spectrum of the unelectrolyzed blank foil. 
(The software had actually returned negative results for the abundances of silver and cadmium, something that happened quite frequently when the abundances of elements were zero. When negative results for the abundances were produced by the program, they were interpreted to be zero and the other, nonnegative results were normalized appropriately to whatever they added up. The surface analysis reached up to a depth of $\sim 1 \mu \mathrm{m}$ and often there was a $\mathrm{Cu}$ signal from the brass stage.)

The $2.839 \mathrm{keV} \mathrm{L}_{\alpha} \mathrm{Pd}$ peak predominated, with a pronounced valley separating it from the next peak in the spectrum, the $2.990 \mathrm{keV} \mathrm{L}_{\beta}$ peak of the same element. This $\mathrm{L}_{\beta} \mathrm{Pd}$ peak could partially overlap with the $2.984 \mathrm{keV} \mathrm{L}_{\alpha}$ peak of $\mathrm{Ag}$ if silver were present. However, the $\mathrm{L}_{\beta} \mathrm{Pd}$ peak rose to a height that was only $34 \%$ that of the $\mathrm{L}_{\alpha} \mathrm{Pd}$ peak (in an ideally pure palladium sample, the X-ray charts report that the height of the $\mathrm{L}_{\beta} \mathrm{Pd}$ peak is $40 \%$ that of the $\mathrm{L}_{\alpha} \mathrm{Pd}$ peak) $)^{54}$. This $34 \% \mathrm{~L}_{\beta} \mathrm{Pd} / \mathrm{L}_{\alpha}$ $\mathrm{Pd}$ ratio indicated that there was certainly no second line that overlapped the $\mathrm{L}_{\beta} \mathrm{Pd}$ peak and hence no silver.

Another spectrum was taken from a spot on the unelectrolyzed Pd foil close to a little archipelago of mesa-like features (FIG. 40).

The results of the quantitative analysis are listed in Table 13. (Table 14 for the metallic elements).

There was again no $\mathrm{Cd}$ or $\mathrm{Ag}$ : 
FIG. 40: Spectrum from spot on unelectrolyzed Pd.

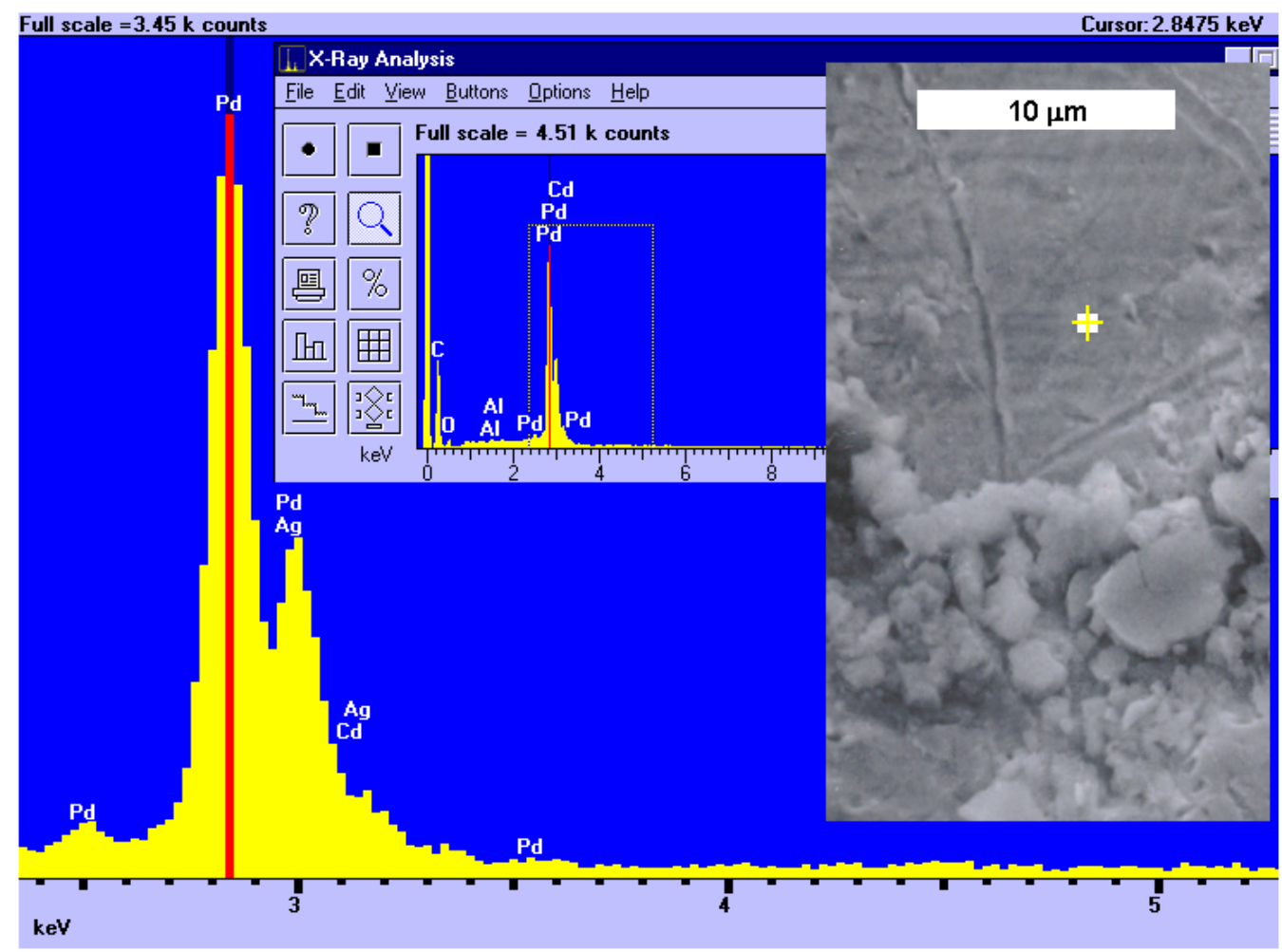

Table 13: Results of elemental analysis from X-ray Spectrum of FIG. 40

\begin{tabular}{lrrr}
\multicolumn{5}{c}{ In number } \\
of atoms & In mass & \multicolumn{2}{l}{$\begin{array}{l}\text { 任 } \\
\text { mass }\end{array}$} \\
$\mathrm{C}$ & $88.50 \%$ & $46.77 \%$ & $1.15 \%$ \\
$\mathrm{O}$ & $0.00 \%$ & $0.00 \%$ & $1.36 \%$ \\
$\mathrm{~S}$ & $0.13 \%$ & $0.18 \%$ & $0.07 \%$ \\
$\mathrm{Cu}$ & $0.16 \%$ & $0.45 \%$ & $0.27 \%$ \\
$\mathrm{Pd}$ & $11.18 \%$ & $52.35 \%$ & $1.14 \%$ \\
$\mathrm{Ag}$ & $0.00 \%$ & $0.00 \%$ & $1.00 \%$ \\
$\mathrm{Cd}$ & $0.00 \%$ & $0.00 \%$ & $0.56 \%$ \\
$\mathrm{Pt}$ & $0.03 \%$ & $0.25 \%$ & $0.22 \%$
\end{tabular}

(Surface analysis up to a depth of $\sim 1 \mu \mathrm{m}$ ). 
Table 14: Results of analysis from X-ray Spectrum of FIG. 40 for metallic elements

\begin{tabular}{|c|c|c|c|}
\hline & $\begin{array}{l}\text { In number } \\
\text { of atoms }\end{array}$ & In mass & $\sigma_{\text {in mass }}$ \\
\hline $\mathrm{Cu}$ & $1.40 \%$ & $0.84 \%$ & $0.50 \%$ \\
\hline $\mathrm{Pd}$ & $98.35 \%$ & $98.68 \%$ & $2.14 \%$ \\
\hline $\mathrm{Ag}$ & $0.00 \%$ & $0.00 \%$ & $1.88 \%$ \\
\hline $\mathrm{Cd}$ & $0.00 \%$ & $0.00 \%$ & $1.05 \%$ \\
\hline $\mathrm{Pt}$ & $0.26 \%$ & $0.47 \%$ & $0.41 \%$ \\
\hline
\end{tabular}

(Surface analysis up to a depth of $\sim 1 \mu \mathrm{m}$ ).

FIG. 41 shows another spot (spot 1) from which X-rays were acquired on the unelectrolyzed foil. Table 15 lists the elemental abundance on that spot. Table 16 lists the abundances for the metallic elements.

FIG. 41: Spectrum from spot 1 on unelectrolyzed Pd.

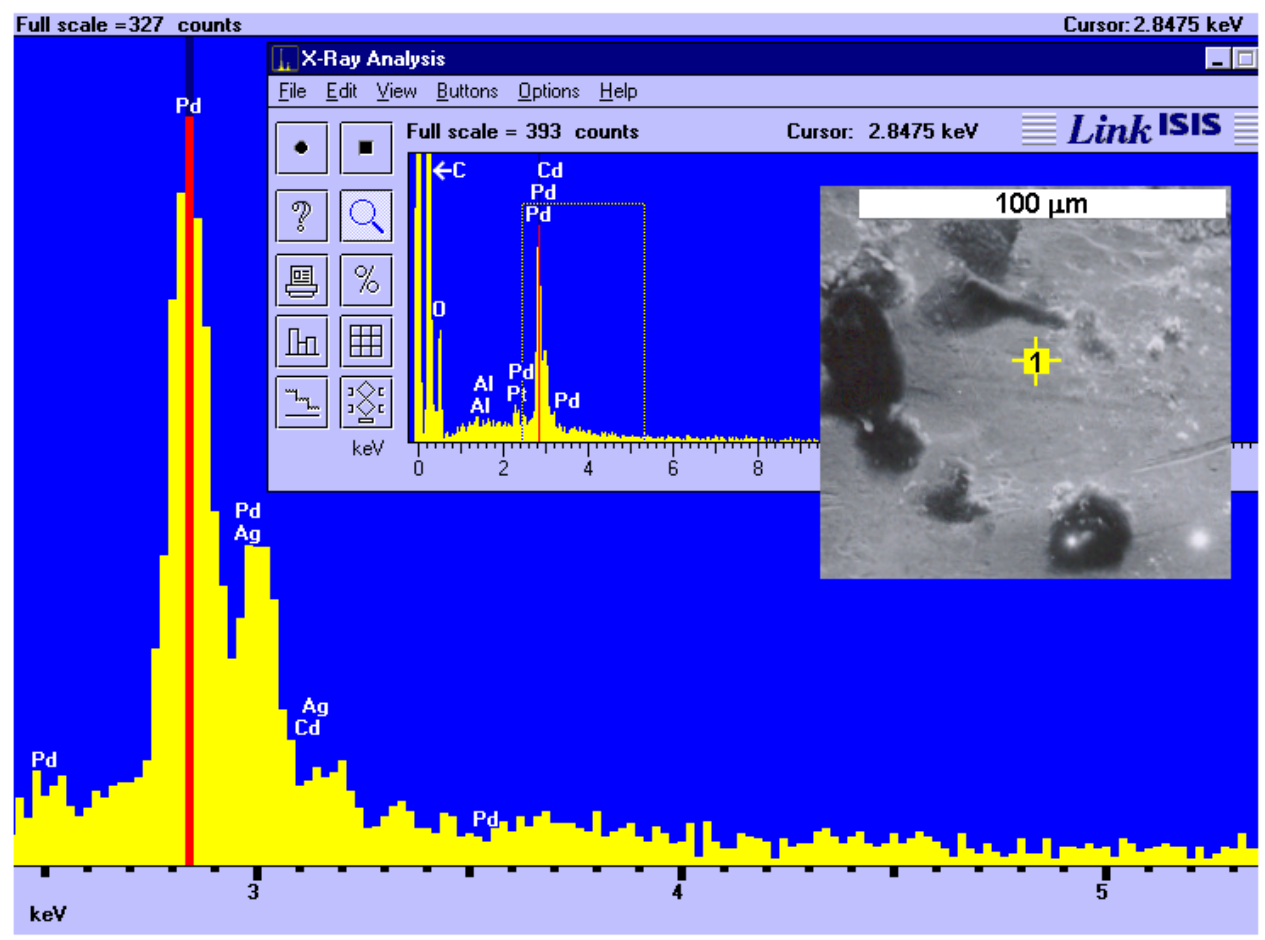


Table 15: Results of elemental analysis of X-ray Spectrum from spot 1 in FIG. 41

\begin{tabular}{lrrr}
\multicolumn{5}{c}{$\begin{array}{l}\text { In number } \\
\text { of atoms }\end{array}$} & In mass & \multicolumn{2}{l}{$\begin{array}{c}\text { 保 } \\
\text { mass }\end{array}$} \\
$\mathrm{C}$ & $97.51 \%$ & $82.61 \%$ & $3.18 \%$ \\
$\mathrm{O}$ & $0.00 \%$ & $0.00 \%$ & $3.25 \%$ \\
$\mathrm{~S}$ & $0.25 \%$ & $0.55 \%$ & $0.12 \%$ \\
$\mathrm{Cu}$ & $0.00 \%$ & $0.00 \%$ & $0.31 \%$ \\
$\mathrm{Pd}$ & $2.23 \%$ & $16.75 \%$ & $1.01 \%$ \\
$\mathrm{Ag}$ & $0.00 \%$ & $0.00 \%$ & $1.10 \%$ \\
$\mathrm{Cd}$ & $0.00 \%$ & $0.00 \%$ & $0.67 \%$ \\
$\mathrm{Pt}$ & $0.01 \%$ & $0.09 \%$ & $0.30 \%$
\end{tabular}

(Surface analysis up to a depth of $\sim 1 \mu \mathrm{m}$ ).

Table 16: Results of analysis of X-ray Spectrum from spot 1 in FIG. 41 for metallic elements

\begin{tabular}{lrrr}
\multicolumn{5}{c}{$\begin{array}{l}\text { In number } \\
\text { of atoms }\end{array}$} & & \\
& In mass & \multicolumn{1}{l}{ 保 mass } \\
$\mathrm{Cu}$ & $0.00 \%$ & $0.00 \%$ & $1.86 \%$ \\
$\mathrm{Pd}$ & $99.62 \%$ & $99.46 \%$ & $6.02 \%$ \\
$\mathrm{Ag}$ & $0.00 \%$ & $0.00 \%$ & $6.56 \%$ \\
$\mathrm{Cd}$ & $0.00 \%$ & $0.00 \%$ & $3.96 \%$ \\
$\mathrm{Pt}$ & $0.38 \%$ & $0.54 \%$ & $1.81 \%$
\end{tabular}

(Surface analysis up to a depth of $\sim 1 \mu \mathrm{m}$ ).

FIG. 42 shows the X-ray spectrum from another spot (spot 2), right next to the previous one.

Table 17 lists the elemental abundance of this spot 2, while Table 18 lists the results for the metallic elements only. 
FIG. 42: Spectrum from spot 2 on unelectrolyzed Pd.

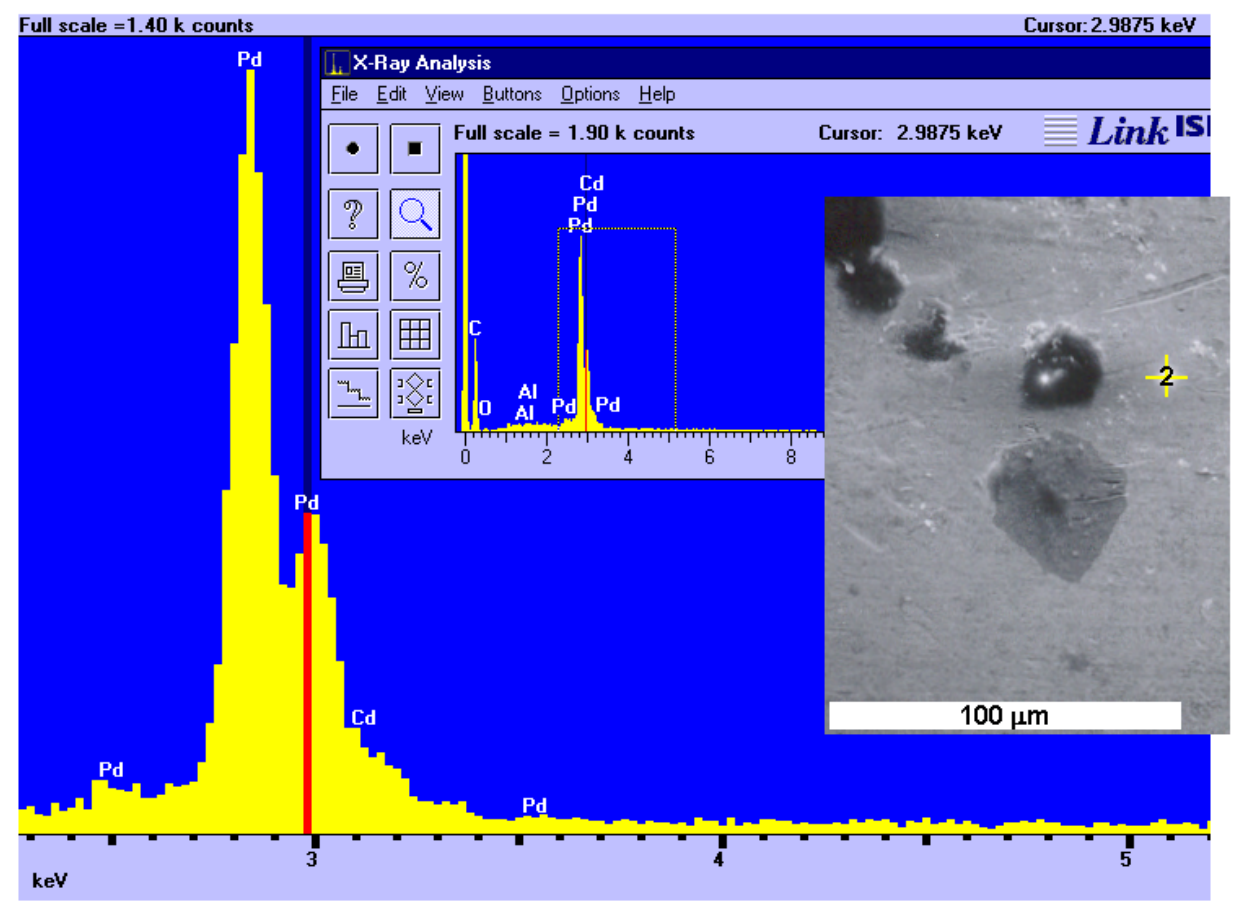

Table 17: Results of elemental analysis of X-ray Spectrum from spot 2 in FIG. 42

\begin{tabular}{lrrr}
\multicolumn{5}{c}{$\begin{array}{l}\text { In number } \\
\text { of atoms }\end{array}$} & In mass & \multicolumn{2}{l}{ 任 mass } \\
$\mathrm{C}$ & $88.01 \%$ & $45.31 \%$ & $1.79 \%$ \\
$\mathrm{O}$ & $0.00 \%$ & $0.00 \%$ & $2.02 \%$ \\
$\mathrm{~S}$ & $0.00 \%$ & $0.00 \%$ & $0.11 \%$ \\
$\mathrm{Cu}$ & $0.00 \%$ & $0.00 \%$ & $0.39 \%$ \\
$\mathrm{Pd}$ & $11.99 \%$ & $54.69 \%$ & $1.85 \%$ \\
$\mathrm{Ag}$ & $0.00 \%$ & $0.00 \%$ & $1.60 \%$ \\
$\mathrm{Cd}$ & $0.00 \%$ & $0.00 \%$ & $0.89 \%$ \\
$\mathrm{Pt}$ & $0.00 \%$ & $0.00 \%$ & $0.35 \%$
\end{tabular}

(Surface analysis up to a depth of $\sim 1 \mu \mathrm{m}$ ). 
Table 18: Results of the analysis of X-ray Spectrum from spot 2 in FIG. 42 for metallic elements

\begin{tabular}{|c|c|c|c|}
\hline & $\begin{array}{l}\text { In number } \\
\text { of atoms }\end{array}$ & In mass & $\sigma_{\text {in mass }}$ \\
\hline $\mathrm{Cu}$ & $0.00 \%$ & $0.00 \%$ & $0.71 \%$ \\
\hline $\mathrm{Pd}$ & $100.00 \%$ & $100.00 \%$ & $3.38 \%$ \\
\hline $\mathrm{Ag}$ & $0.00 \%$ & $0.00 \%$ & $2.92 \%$ \\
\hline $\mathrm{Cd}$ & $0.00 \%$ & $0.00 \%$ & $1.63 \%$ \\
\hline $\mathrm{Pt}$ & $0.00 \%$ & $0.00 \%$ & $0.64 \%$ \\
\hline
\end{tabular}

(Surface analysis up to a depth of $\sim 1 \mu \mathrm{m}$ ).

\section{APPENDIX E: ADDITIONAL SPECTRA FROM THE H CELL CATHODE OF THE FIRST EXPERIMENT} AFTER ELECTROLYSIS.

The spectrum shown in FIG. 7 from the $\mathrm{H}$ cell cathode of the first experiment after electrolysis was taken from a large $2.1 \mathrm{~mm} \times 2.1 \mathrm{~mm}$ selected area near the tip of the cathode which is shown in FIG. 43. 
FIG. 43: Tip of $\mathrm{H}$ cell cathode of first experiment after electrolysis, concave side.

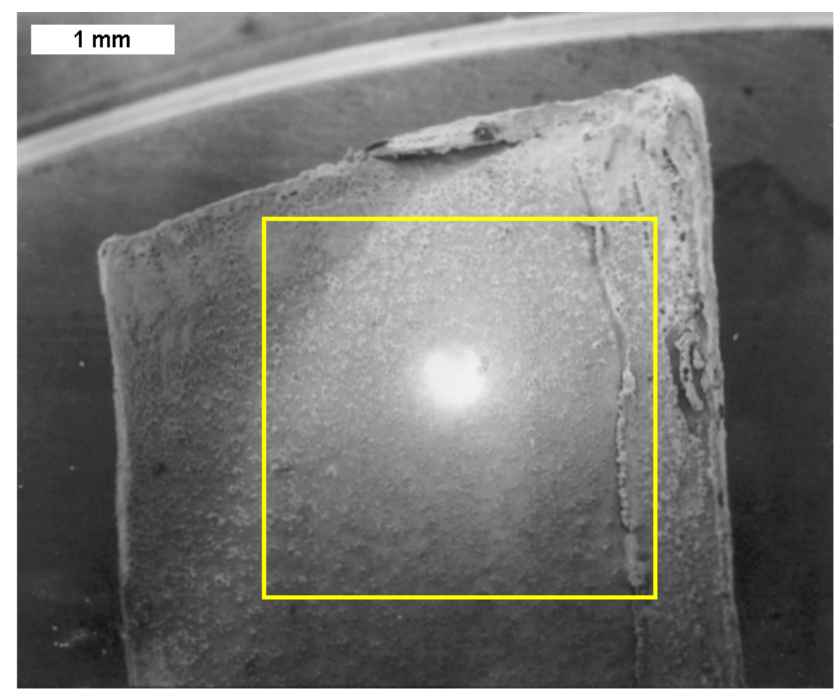

On the opposite side of this $\mathrm{H}$ cell cathode, the concentration of Ag was lower but still statistically significant.

FIG. 44 shows the selected area from which X-rays were acquired on this other, convex side of the $\mathrm{H}$ cell cathode near its tip. FIG. 45 displays the full X-ray spectrum.

Table 19 lists the results of the SEMQuant analysis for all the elements, while Table 20 lists the results for the metallic elements only: 
FIG. 44: Tip of $\mathrm{H}$ cell cathode of first experiment after electrolysis, convex side.

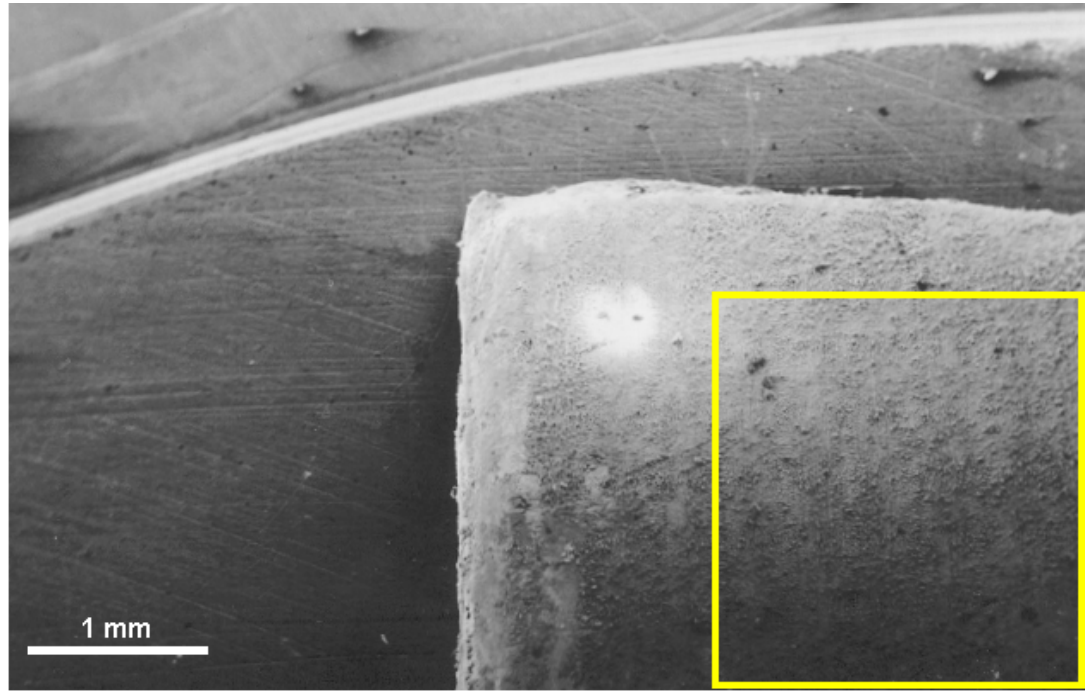

FIG. 45: Spectrum from $2.2 \mathrm{~mm} \times 2.2 \mathrm{~mm}$ selected area in FIG. 44 .

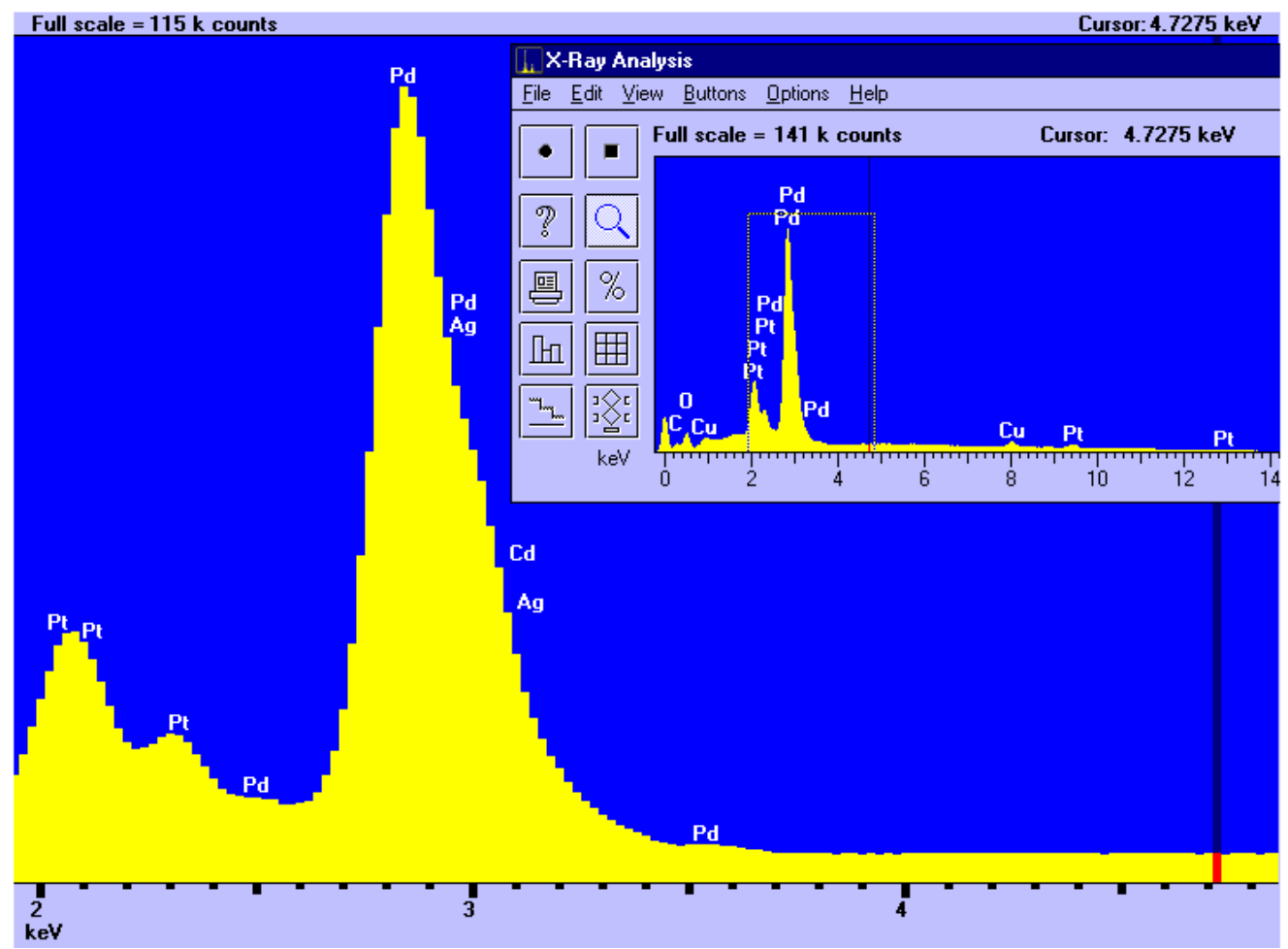


Table 19: Results of elemental analysis of spectrum of FIG. 45, from selected area in FIG. 44.

\begin{tabular}{lrrr}
\multicolumn{4}{c}{ In number } \\
of atoms & In mass & \multicolumn{1}{c}{ 更 mass } \\
C & $0.35 \%$ & $0.07 \%$ & $0.06 \%$ \\
$\mathrm{O}$ & $53.19 \%$ & $14.87 \%$ & $0.16 \%$ \\
$\mathrm{~S}$ & $5.06 \%$ & $2.84 \%$ & $0.04 \%$ \\
$\mathrm{Cu}$ & $2.43 \%$ & $2.70 \%$ & $0.08 \%$ \\
$\mathrm{Pd}$ & $33.74 \%$ & $62.74 \%$ & $0.25 \%$ \\
$\mathrm{Ag}$ & $0.67 \%$ & $1.26 \%$ & $0.24 \%$ \\
$\mathrm{Cd}$ & $0.03 \%$ & $0.07 \%$ & $0.18 \%$ \\
$\mathrm{Pt}$ & $4.53 \%$ & $15.45 \%$ & $0.11 \%$
\end{tabular}

(Surface analysis up to a depth of $\sim 1 \mu \mathrm{m}$. Some of the $\mathrm{Cu}$ reading might have been a systems peak from the brass stage.)

Table 20: Results of spectrum of FIG. 45, from selected area in FIG. 44, for the metallic elements. An actual separate SEMQuant analysis was conducted for the metallic elements only.

\begin{tabular}{lrrr}
\multicolumn{5}{c}{ In number } \\
of atoms & In mass & \multicolumn{1}{c}{$\sigma_{\text {in mass }}$} \\
$\mathrm{Cu}$ & $5.98 \%$ & $3.39 \%$ & $0.10 \%$ \\
$\mathrm{Pd}$ & $82.65 \%$ & $78.54 \%$ & $0.33 \%$ \\
$\mathrm{Ag}$ & $1.99 \%$ & $1.92 \%$ & $0.29 \%$ \\
$\mathrm{Cd}$ & $0.27 \%$ & $0.27 \%$ & $0.23 \%$ \\
$\mathrm{Pt}$ & $9.11 \%$ & $15.88 \%$ & $0.13 \%$
\end{tabular}

(Surface analysis up to a depth of $\sim 1 \mu \mathrm{m}$. Some of the $\mathrm{Cu}$ reading might have been a systems peak from the brass stage.) 


\section{APPENDIX F: ADDITIONAL SPECTRA FROM THE D CELL CATHODE OF THE FIRST EXPERIMENT}

AFTER ELECTROLYSIS.

On the D cell cathode of this first experiment, X-rays were collected from a large (2 $\mathrm{mm} \times 2 \mathrm{~mm}$ ) area on the concave side near the tip.

Silver was spotted in small but statistically significant amounts.

The region with the X-ray acquisition area is imaged in FIG. 46; the X-ray spectrum is displayed in FIG. 47; the results of the SEMQuant analysis are listed in Tables 21 (for all the elements) and 22 (for the metallic elements only).

FIG. 46: Tip of D cell cathode of the first experiment after electrolysis, concave side

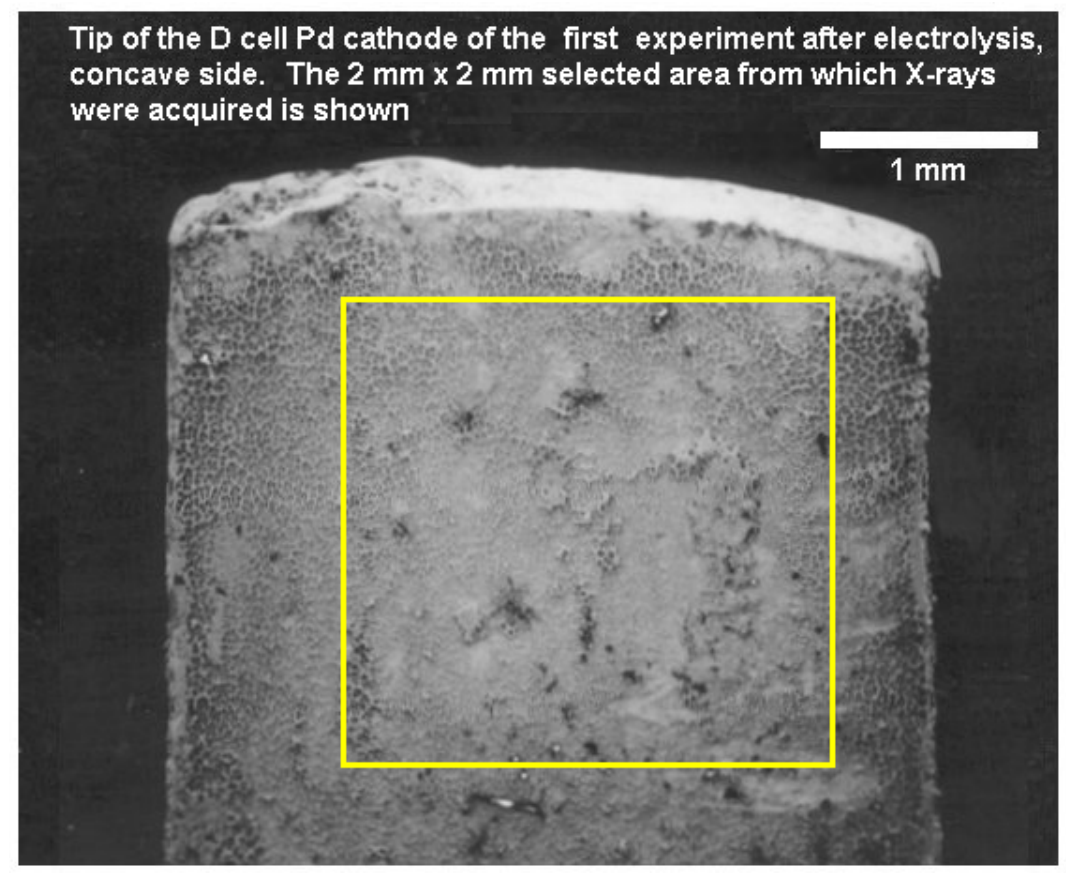


FIG. 47: Spectrum from $2 \mathrm{~mm} \times 2 \mathrm{~mm}$ selected area in FIG. 46

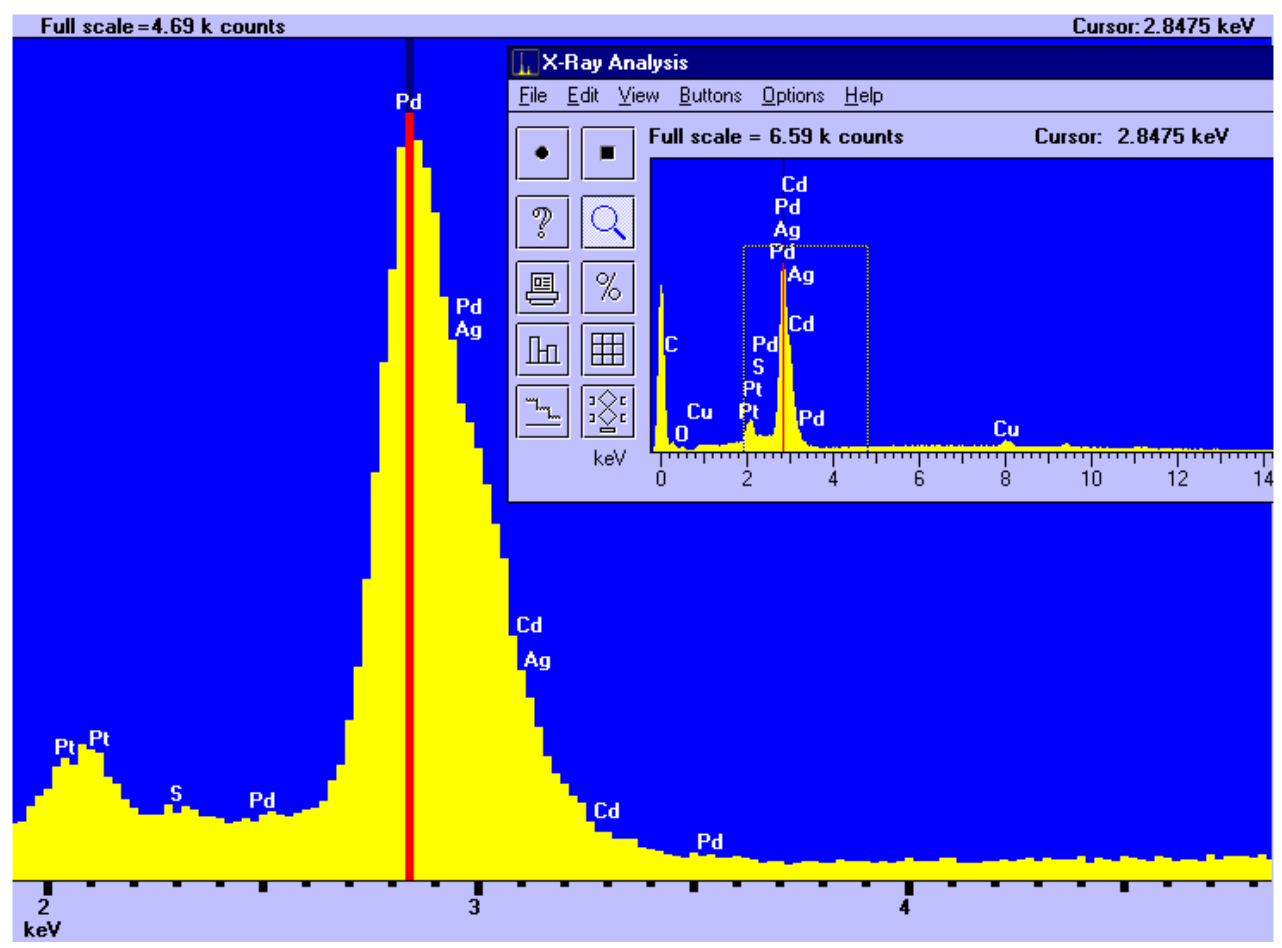

Table 21: Results of elemental analysis of spectrum of FIG. 47, from selected area in FIG. 46

\begin{tabular}{lrrr}
\multicolumn{5}{c}{$\begin{array}{l}\text { In number } \\
\text { of atoms }\end{array}$} & In mass & \multicolumn{1}{c}{ 而 mass } \\
C & $0.00 \%$ & $0.00 \%$ & $0.41 \%$ \\
$\mathrm{O}$ & $16.73 \%$ & $2.98 \%$ & $0.77 \%$ \\
$\mathrm{~S}$ & $3.66 \%$ & $1.30 \%$ & $0.19 \%$ \\
$\mathrm{Cu}$ & $6.82 \%$ & $4.83 \%$ & $0.60 \%$ \\
$\mathrm{Pd}$ & $63.89 \%$ & $75.70 \%$ & $1.75 \%$ \\
$\mathrm{Ag}$ & $4.28 \%$ & $5.14 \%$ & $1.34 \%$ \\
$\mathrm{Cd}$ & $0.00 \%$ & $0.00 \%$ & $1.08 \%$ \\
$\mathrm{Pt}$ & $4.62 \%$ & $10.04 \%$ & $0.55 \%$
\end{tabular}

(Surface analysis up to a depth of $\sim 1 \mu \mathrm{m}$. Some of the $\mathrm{Cu}$ reading might have been a systems peak from the brass stage.) 
Table 22: Results of analysis of spectrum of FIG. 47, from selected area in FIG. 46, for the metallic elements. An actual separate SEMQuant analysis was conducted for the metallic elements only.

\begin{tabular}{lrrr}
\multicolumn{5}{c}{$\begin{array}{l}\text { In number } \\
\text { of atoms }\end{array}$} & In mass & \multicolumn{1}{c}{ 位 mass } \\
& $8.76 \%$ & $5.19 \%$ & $0.64 \%$ \\
$\mathrm{Cu}$ & $80.67 \%$ & $80.07 \%$ & $1.67 \%$ \\
$\mathrm{Pd}$ & $5.53 \%$ & $5.57 \%$ & $1.41 \%$ \\
$\mathrm{Ag}$ & $0.00 \%$ & $0.00 \%$ & $1.13 \%$ \\
$\mathrm{Cd}$ & $5.04 \%$ & $9.17 \%$ & $0.53 \%$ \\
$\mathrm{Pt}$ & & &
\end{tabular}

(Surface analysis up to a depth of $\sim 1 \mu \mathrm{m}$. Some of the $\mathrm{Cu}$ reading might have been a systems peak from the brass stage.)

On the opposite side of the $\mathrm{D}$ cell cathode, $\mathrm{X}$-rays were collected from two small $13 \mu \mathrm{m} \times 13 \mu \mathrm{m}$ areas. They are shown in FIG. 48.

FIG. 48: Micrograph of convex side of the D cell cathode of the first experiment after electrolysis

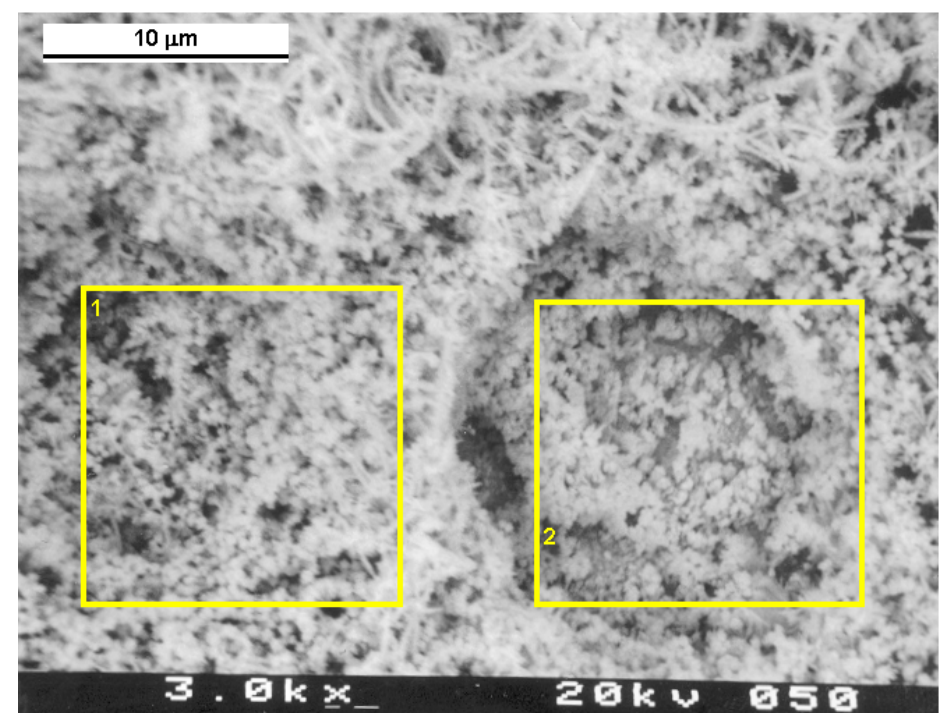


The X-ray spectrum from selected area 1, to the left, is shown in FIG. 49. The results of the SEMQuant analysis of this spectrum are listed in Tables 23 (for all the elements) and 24 (for the metallic elements only). There was over 1 atom of $\mathrm{Ag}$ for $5 \mathrm{of} \mathrm{Pd}$.

FIG. 49: Spectrum from selected area 1 in FIG. 48

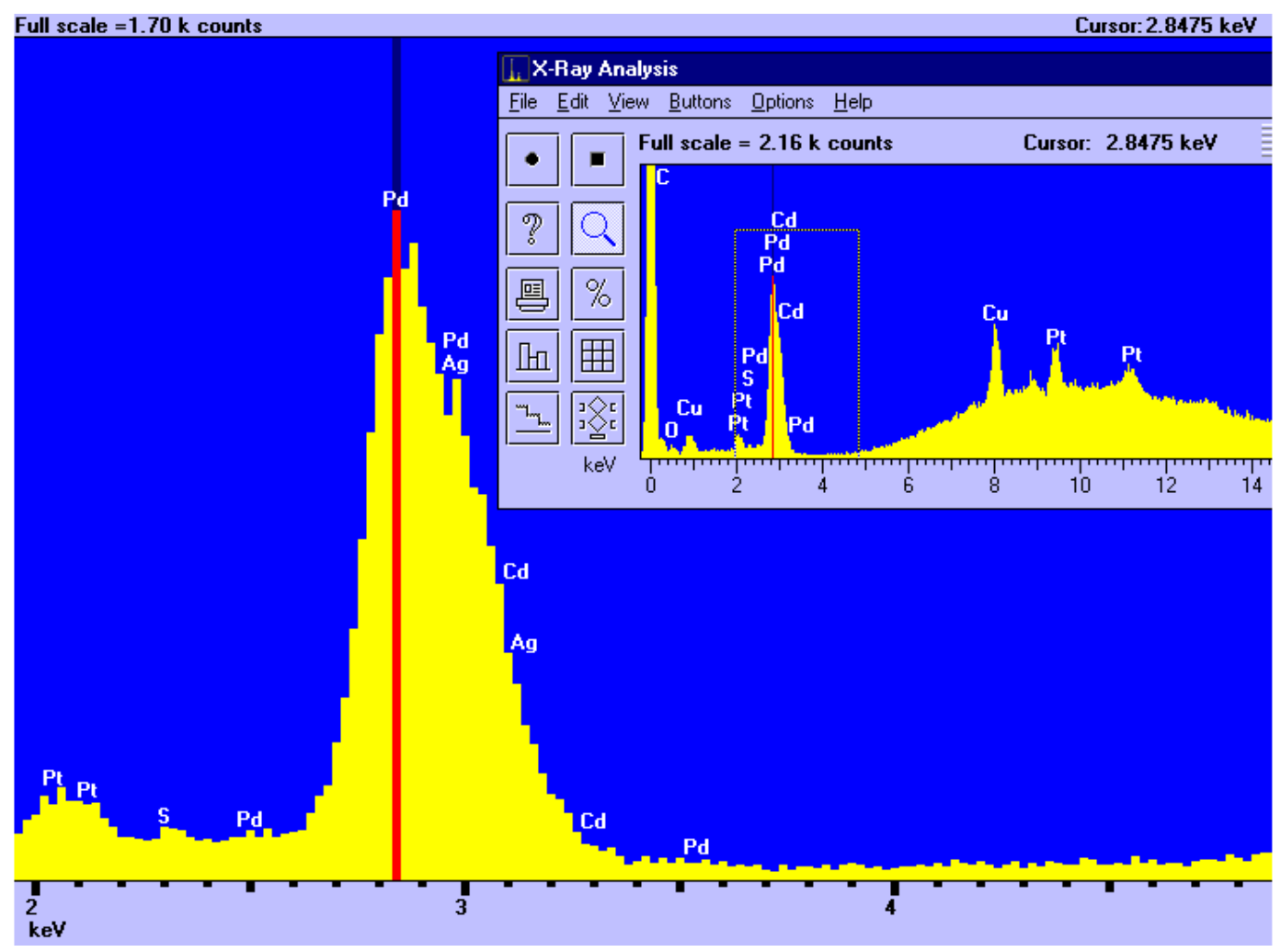

Table 23: Results of elemental analysis of spectrum of FIG. 49, from selected area 1 in FIG. 48.

\begin{tabular}{lrrr}
\multicolumn{5}{c}{$\begin{array}{l}\text { In number } \\
\text { of atoms }\end{array}$} & In mass & \multicolumn{1}{c}{$\sigma_{\text {in }}$ mass } \\
& $0.00 \%$ & $0.00 \%$ & $1.42 \%$ \\
$\mathrm{C}$ & $23.11 \%$ & $5.28 \%$ & $0.98 \%$ \\
$\mathrm{O}$ & $1.68 \%$ & $0.77 \%$ & $0.18 \%$ \\
$\mathrm{~S}$ & $37.33 \%$ & $33.87 \%$ & $1.71 \%$ \\
$\mathrm{Cu}$ & $29.58 \%$ & $44.93 \%$ & $1.90 \%$ \\
$\mathrm{Pd}$ & $6.35 \%$ & $9.79 \%$ & $1.39 \%$ \\
$\mathrm{Ag}$ & $0.00 \%$ & $0.00 \%$ & $1.17 \%$ \\
$\mathrm{Cd}$ & $1.92 \%$ & $5.36 \%$ & $0.57 \%$ \\
$\mathrm{Pt}$ & & &
\end{tabular}


(Surface analysis up to a depth of $\sim 1 \mu \mathrm{m}$. Some of the $\mathrm{Cu}$ reading might have been a systems peak from the brass stage. The listed number concentrations were not the actual results of the software, which returned negative values for all the elements except carbon, but were inferred from the mass results)

Table 24: Results of analysis of spectrum of FIG. 49, from selected area 1 in FIG. 48, for the metallic elements only. An actual separate SEMQuant analysis was conducted for the metallic elements only.

\begin{tabular}{lrrr}
\multicolumn{5}{c}{$\begin{array}{l}\text { In number } \\
\text { of atoms }\end{array}$} & In mass & \multicolumn{1}{c}{ 位 mass } \\
$\mathrm{Cu}$ & $49.91 \%$ & $36.45 \%$ & $1.75 \%$ \\
$\mathrm{Pd}$ & $39.36 \%$ & $48.14 \%$ & $1.71 \%$ \\
$\mathrm{Ag}$ & $8.63 \%$ & $10.70 \%$ & $1.51 \%$ \\
$\mathrm{Cd}$ & $0.00 \%$ & $0.00 \%$ & $1.27 \%$ \\
$\mathrm{Pt}$ & $2.10 \%$ & $4.71 \%$ & $0.56 \%$
\end{tabular}

(Surface analysis up to a depth of $\sim 1 \mu \mathrm{m}$. Some of the $\mathrm{Cu}$ reading might have been a systems peak from the brass stage.)

The X-ray spectrum from selected area 2 in FIG. 48, to the right, is shown in FIG. 50.

The results of the SEMQuant analysis of this spectrum are listed in Tables 25 (for all the elements) and 26 (for the metallic elements only).

There was over 1 atom of $\mathrm{Ag}$ for $7 \mathrm{of} \mathrm{Pd}$. 
FIG. 50: Spectrum from selected area 2 in FIG. 48

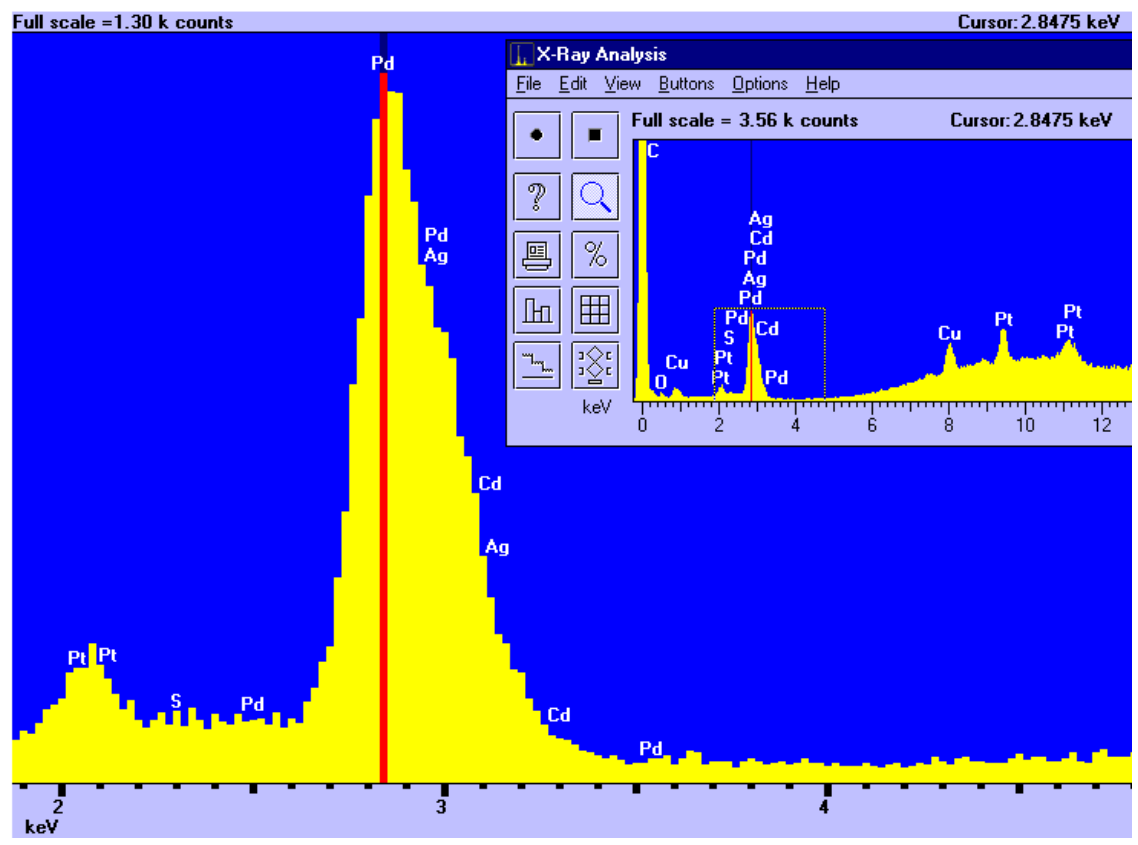

Table 25: Results of elemental analysis of spectrum of FIG. 50, from selected area 2 in FIG. 48.

\begin{tabular}{lrrr}
\multicolumn{5}{c}{$\begin{array}{l}\text { In number } \\
\text { of atoms }\end{array}$} & In mass & \multicolumn{1}{c}{ 佂 mass } \\
$\mathrm{C}$ & $100.00 \%$ & $0.00 \%$ & $2.23 \%$ \\
$\mathrm{O}$ & $31.31 \%$ & $7.61 \%$ & $1.20 \%$ \\
$\mathrm{~S}$ & $1.77 \%$ & $0.86 \%$ & $0.22 \%$ \\
$\mathrm{Cu}$ & $30.54 \%$ & $29.48 \%$ & $1.88 \%$ \\
$\mathrm{Pd}$ & $29.74 \%$ & $48.07 \%$ & $2.48 \%$ \\
$\mathrm{Ag}$ & $4.26 \%$ & $6.98 \%$ & $1.56 \%$ \\
$\mathrm{Cd}$ & $0.02 \%$ & $0.04 \%$ & $1.28 \%$ \\
$\mathrm{Pt}$ & $2.34 \%$ & $6.95 \%$ & $0.72 \%$
\end{tabular}

(Surface analysis up to a depth of $\sim 1 \mu \mathrm{m}$. Some of the $\mathrm{Cu}$ reading might have been a systems peak from the brass stage. The listed number concentrations were not the actual results of the software, which returned negative values for all the elements except carbon, but were inferred from the mass results) 
Table 26: Results of analysis of spectrum of FIG. 50, from selected area 2 in FIG. 48, for the metallic elements only. An actual separate SEMQuant analysis was conducted for the metallic elements only.

\begin{tabular}{lrrr}
\multicolumn{5}{c}{ In number } \\
of atoms & In mass & \multicolumn{1}{c}{ 位 mass } \\
$\mathrm{Cu}$ & $45.87 \%$ & $69.29 \%$ & $4.15 \%$ \\
$\mathrm{Pd}$ & $44.59 \%$ & $0.01 \%$ & $4.30 \%$ \\
$\mathrm{Ag}$ & $6.46 \%$ & $16.57 \%$ & $3.72 \%$ \\
$\mathrm{Cd}$ & $0.06 \%$ & $0.15 \%$ & $3.02 \%$ \\
$\mathrm{Pt}$ & $3.01 \%$ & $13.98 \%$ & $1.49 \%$
\end{tabular}

(Surface analysis up to a depth of $\sim 1 \mu \mathrm{m}$. Some of the $\mathrm{Cu}$ reading might have been a systems peak from the brass stage.)

\section{APPENDIX G: ADDITIONAL MICROGRAPHS AND SPECTRA FROM THE H CELL CATHODE OF THE SECOND EXPERIMENT AFTER ELECTROLYSIS.}

FIGS. 51 and 52 contrast the appearance of the side opposite the spotweld of the $\mathrm{H}$ cell cathode of the second experiment before and after electrolysis. The tip was just as straight after the electrolysis as it was before. 
FIG. 51: H cell cathode of the second experiment before electrolysis (side opposite the spotweld)

\section{Before electrolysis}

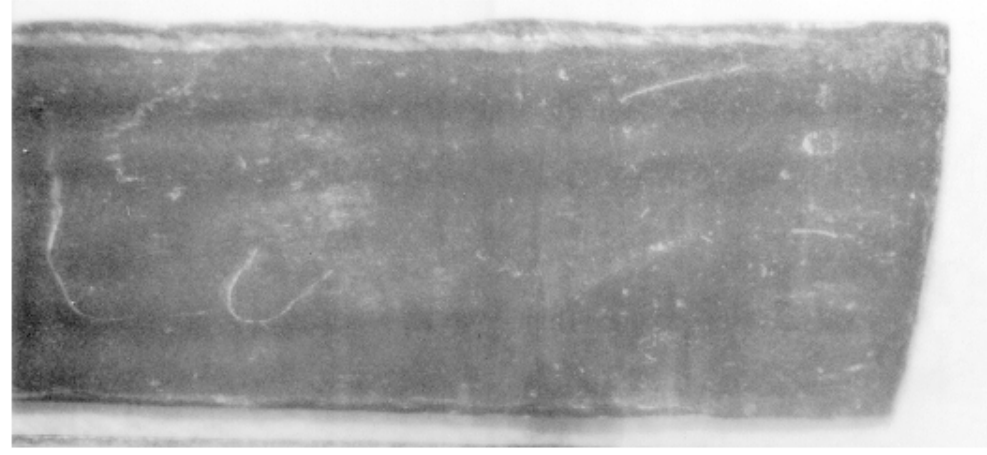

$1 \mathrm{~mm}$

FIG. 52: $\mathrm{H}$ cell cathode of the second experiment after electrolysis (side opposite the spotweld)

$1 \mathrm{~mm}$

After electrolysis

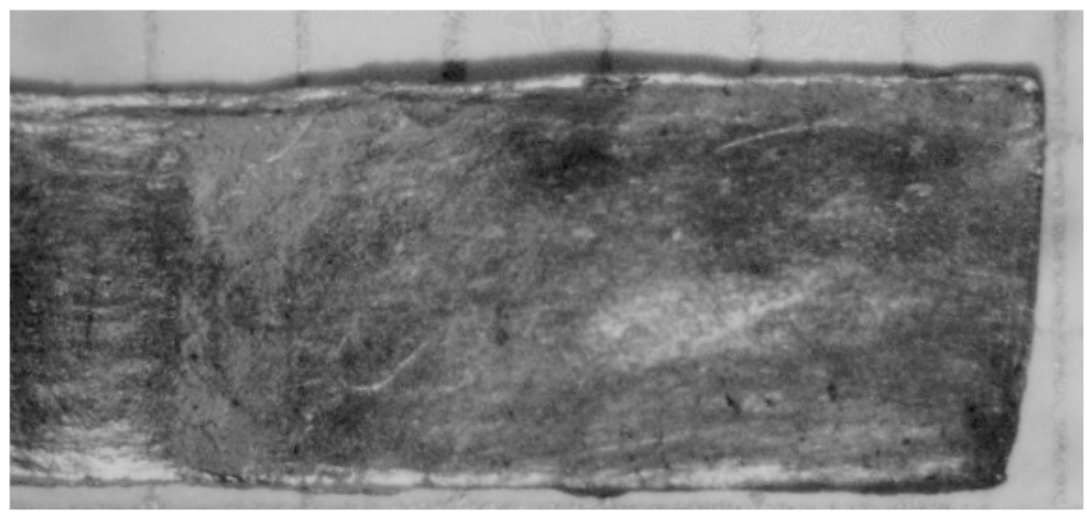

The spotweld side of this $\mathrm{H}$ cell cathode of the second experiment had been facing the anode during electrolysis. To the SEM, the cathode revealed after electrolysis 
tiny fractures such as those towards the tip of the cathode shown in FIG. 53 and some interesting $20 \mu \mathrm{m}$-sized features like the one shown in FIG. 54.

FIG. 53: Tip of $\mathrm{H}$ cell cathode of the second experiment after electrolysis (side opposite the spotweld, looking away from the anode). This tip was lowest in the electrolyte.

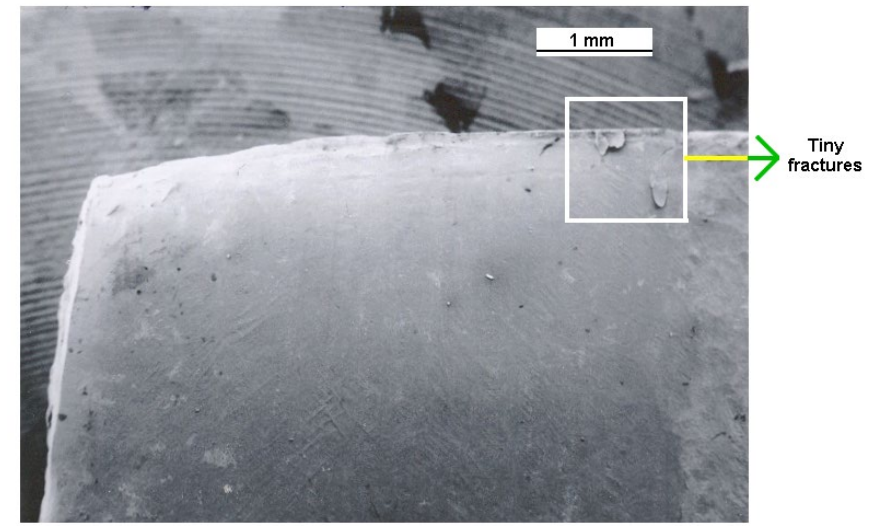

FIG. 54: Granule-covered region near the tip of the $\mathrm{H}$ cell cathode after electrolysis (the lower tip in the electrolyte). This side of the cathode was looking away from the anode. The $23 \mu \mathrm{m} \times 16 \mu \mathrm{m}$ blob-like feature is prominent.

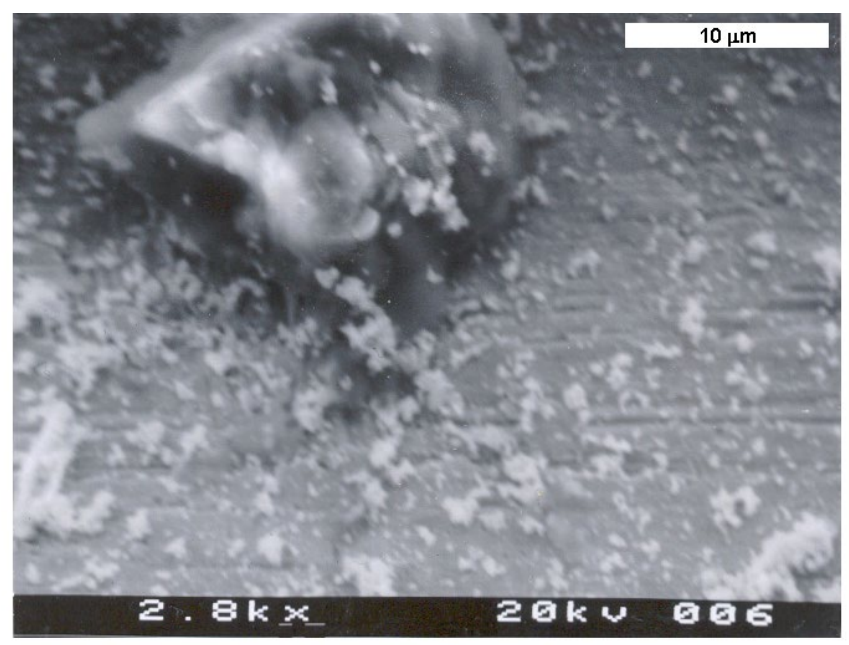


Near the edges, the granules seemed to proliferate to the point of merging with each other into a dainty, sponge-like undulating blanket. A striking pyramid-shaped crystal was found on the side opposite the spotweld, about $2 \mathrm{~cm}$ from the lower edge and $6.5 \mathrm{~mm}$ from the right edge. It had a base of $\sim 37 \mu \mathrm{m}$. There were a few isolated dark areas of $\sim 20 \mu \mathrm{m}$ diameter that looked like stains. There were striations. There were crannies and there were pores. And there were new elements.

A $2.35 \mathrm{~mm} \times 2.35 \mathrm{~mm}$ area selected from the side of the $\mathrm{H}$ cathode opposite the spotweld, which was looking away from the anode (FIG. 55), had a number abundance of cadmium of $4.40 \pm 0.71 \%$ relative to Pd. The spectrum is shown in FIG. 56 and the results of the quantitative analysis are listed in Table 27. Table 28 lists the results for the metallic elements only:

FIG. 55: Side opposite the spotweld on the surface of the $\mathrm{H}$ cell cathode after electrolysis. This side had been looking away from the anode. The $2.35 \mathrm{~mm} \times 2.35 \mathrm{~mm}$ selected area from which X-rays were acquired is shown.

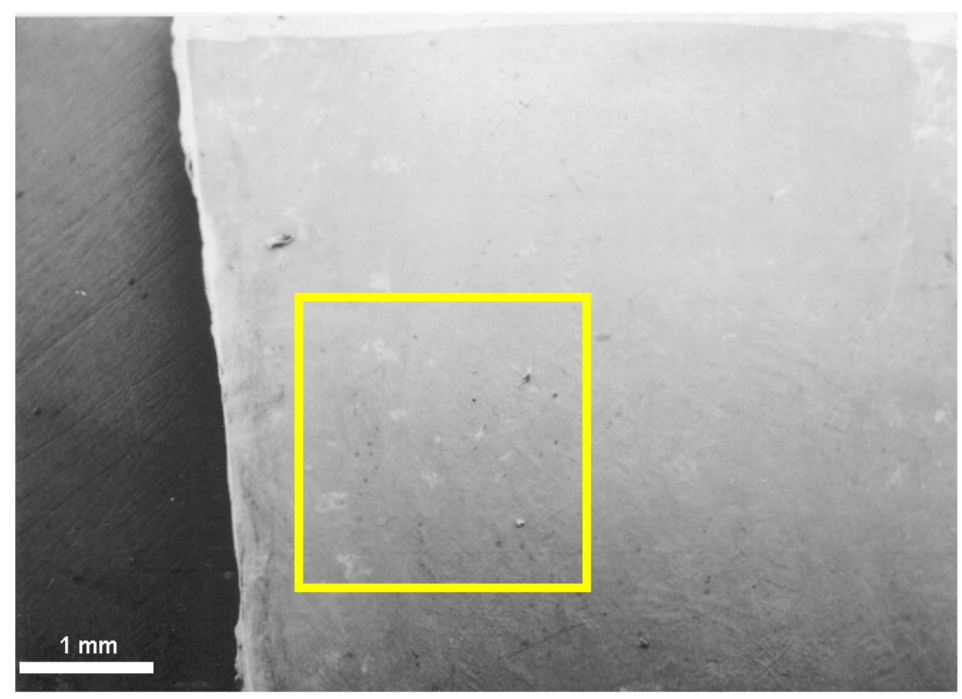


FIG. 56: Spectrum from selected area in FIG. 55.

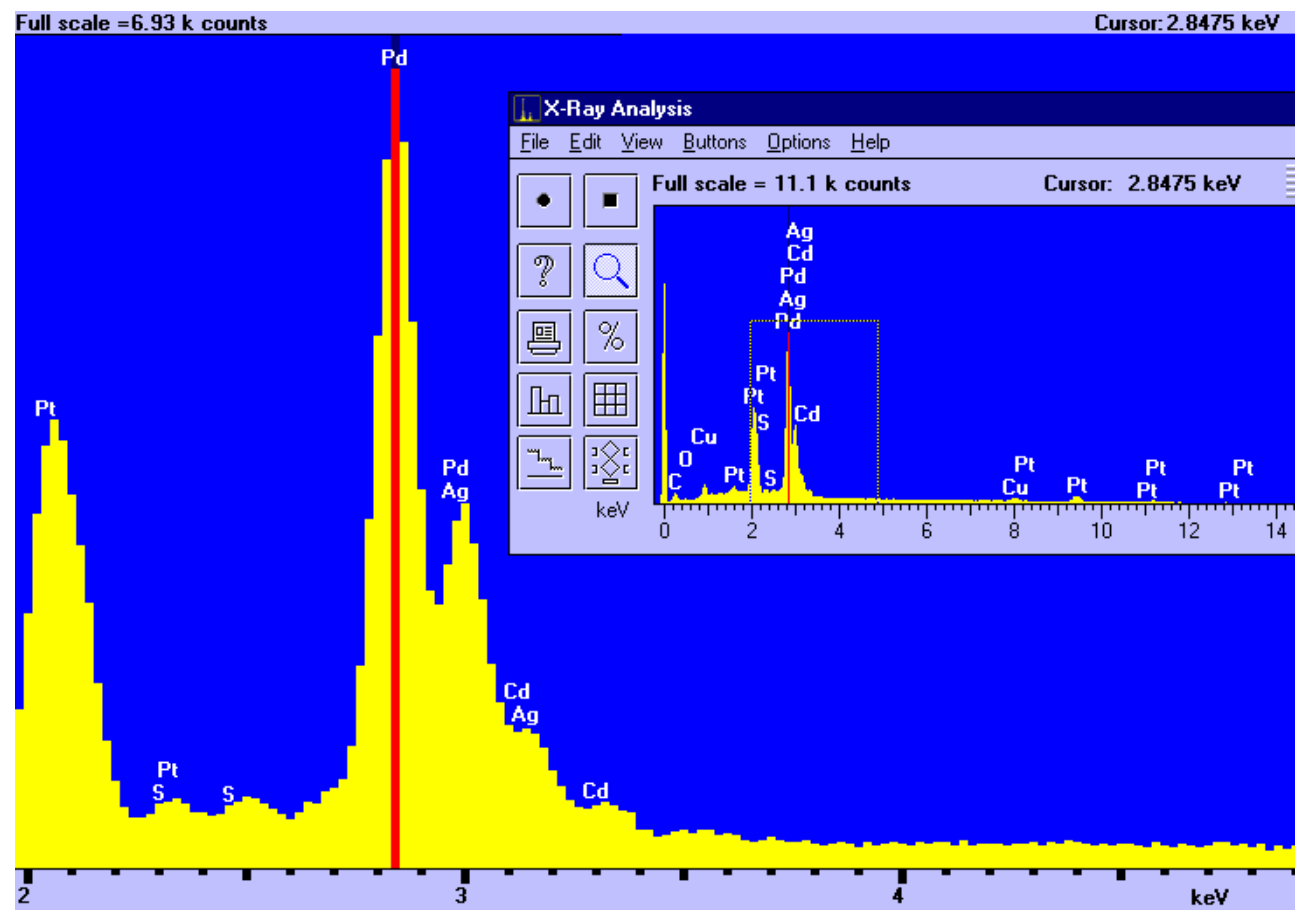

Table 27: Results of elemental analysis of X-ray spectrum of FIG. 56, from selected area in FIG. 55.

\begin{tabular}{lrrr}
\multicolumn{5}{c}{$\begin{array}{l}\text { In number } \\
\text { of atoms }\end{array}$} & In mass & \multicolumn{2}{l}{ 位 mass } \\
$\mathrm{C}$ & $29.59 \%$ & $4.21 \%$ & $0.16 \%$ \\
$\mathrm{O}$ & $4.43 \%$ & $0.84 \%$ & $0.35 \%$ \\
$\mathrm{~S}$ & $0.89 \%$ & $0.34 \%$ & $0.10 \%$ \\
$\mathrm{Cu}$ & $3.05 \%$ & $2.29 \%$ & $0.25 \%$ \\
$\mathrm{Pd}$ & $46.66 \%$ & $58.85 \%$ & $0.66 \%$ \\
$\mathrm{Ag}$ & $0.09 \%$ & $0.12 \%$ & $0.69 \%$ \\
$\mathrm{Cd}$ & $2.05 \%$ & $2.74 \%$ & $0.45 \%$ \\
$\mathrm{Pt}$ & $13.24 \%$ & $30.61 \%$ & $0.44 \%$
\end{tabular}

(Surface analysis up to a depth of $\sim 1 \mu \mathrm{m}$. Some of the $\mathrm{Cu}$ reading might have been a systems peak from the brass stage). 
Table 28: Results of analysis of FIG. 56, from selected area in FIG. 55, for the metallic elements. An actual separate SEMQuant analysis was conducted for these elements only.

\begin{tabular}{lrrr}
\multicolumn{5}{c}{ In number } & & \\
& of atoms & In mass & \multicolumn{1}{l}{ 位 mass } \\
$\mathrm{Cu}$ & $4.65 \%$ & $2.41 \%$ & $0.27 \%$ \\
$\mathrm{Pd}$ & $71.80 \%$ & $62.33 \%$ & $0.68 \%$ \\
$\mathrm{Ag}$ & $0.15 \%$ & $0.13 \%$ & $0.73 \%$ \\
$\mathrm{Cd}$ & $3.16 \%$ & $2.90 \%$ & $0.47 \%$ \\
$\mathrm{Pt}$ & $20.24 \%$ & $32.23 \%$ & $0.46 \%$
\end{tabular}

(Surface analysis up to a depth of $\sim 1 \mu \mathrm{m}$. Some of the $\mathrm{Cu}$ reading might have been a systems peak from the brass stage).

The platinum had been deposited from the anode. It was also more than reasonable to find sulfur, perhaps in the form of sulfides. But the cadmium was a remarkable new finding, and there were also suggestive indications that silver was present. The $3.133 \mathrm{keV} \mathrm{L}_{\alpha}$ and $3.316 \mathrm{keV} \mathrm{L}_{\beta} \mathrm{Cd}$ peaks were markedly visible in the spectrum as humps on the descending slope of the $2.990 \mathrm{keV} \mathrm{L}_{\beta} \mathrm{Pd}$ peak. This time the $\mathrm{L}_{\beta} \mathrm{Pd}$ peak rose to $45 \%$ the height of the main $2.839 \mathrm{~L}_{\alpha}$ Pd peak, which was consistent with a very tenuous $2.984 \mathrm{keV} \mathrm{L} \alpha \mathrm{Ag}$ signal. (The $3.150 \mathrm{keV} \mathrm{L}_{\beta} \mathrm{Ag}$ line overlaps in turn the $3.133 \mathrm{keV} \mathrm{Cd} \mathrm{L}_{\alpha}$ line).

Focusing on a region that featured a $\sim 63 \mu \mathrm{m} \times 28 \mu \mathrm{m}$ flake partially darkened by a circular stain of $10 \mu \mathrm{m}$ radius that extended outside the flake (FIG. 57), the presence of cadmium was confirmed. Acquiring X-rays from a spot right in the center of the dark circular patch (spot 1), a Cd signal above 3 standard deviations 
was detected. The spectrum from this spot is shown in FIG. 58 and the results of the quantitative analysis are shown in Table 29. Table 30 lists the results for the metallic elements only. The number abundance of $\mathrm{Cd}$ was $14.44 \pm 4.48 \%$, relative to $\operatorname{Pd}$.

FIG. 57: Micrograph of a flake on a dark patch on the $\mathrm{H}$ cell cathode after electrolysis, side opposite the spotweld (looking away from the anode). The two spots from which X-rays were acquired are shown.

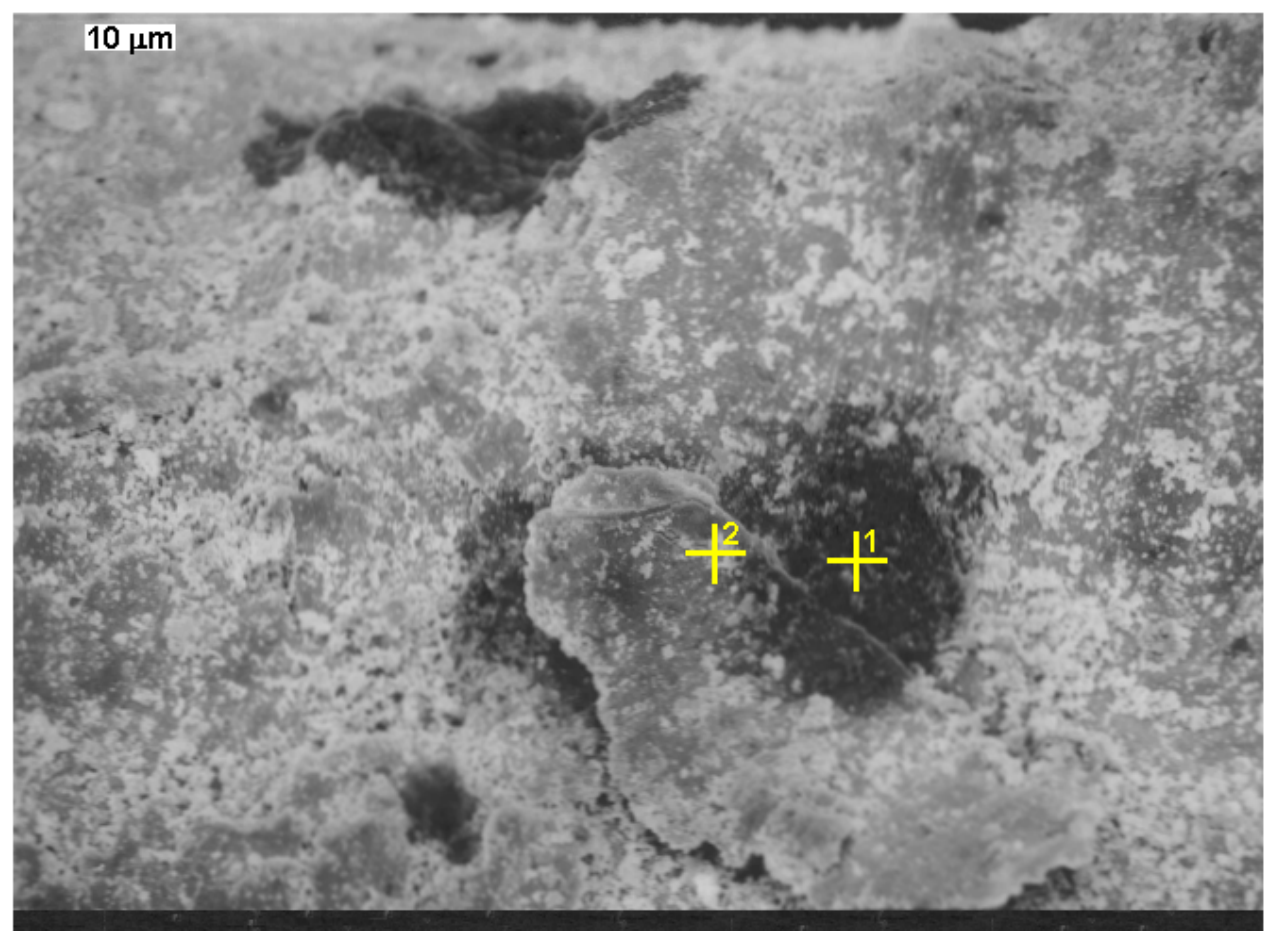


FIG. 58: Spectrum from spot 1 in FIG. 57.

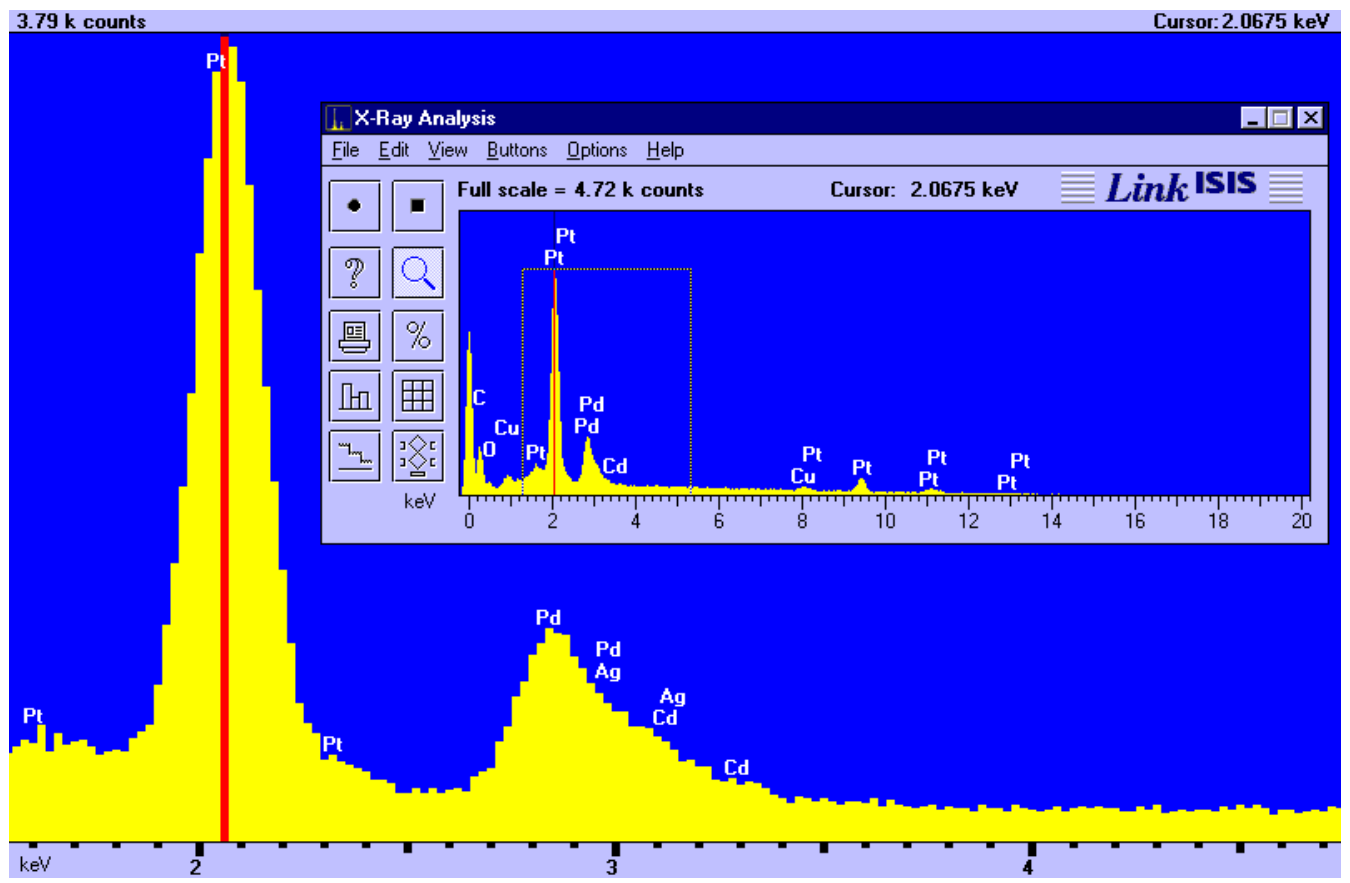

Table 29: Results of elemental analysis of X-ray spectrum of FIG. 58 (from spot 1 in FIG.

$57)$.

\begin{tabular}{|c|c|c|c|}
\hline & $\begin{array}{l}\text { In number } \\
\text { of atoms }\end{array}$ & In mass & $\sigma_{\text {in mass }}$ \\
\hline C & $54.68 \%$ & $10.09 \%$ & $0.93 \%$ \\
\hline $\mathrm{O}$ & $7.22 \%$ & $1.77 \%$ & $0.92 \%$ \\
\hline$S$ & $0.65 \%$ & $0.32 \%$ & $0.32 \%$ \\
\hline $\mathrm{Cu}$ & $2.26 \%$ & $2.20 \%$ & $0.47 \%$ \\
\hline $\mathrm{Pd}$ & $12.47 \%$ & $20.37 \%$ & $0.94 \%$ \\
\hline $\mathrm{Ag}$ & $0.40 \%$ & $0.67 \%$ & $1.13 \%$ \\
\hline $\mathrm{Cd}$ & $1.80 \%$ & $3.11 \%$ & $0.97 \%$ \\
\hline $\mathrm{Pt}$ & $20.52 \%$ & $61.47 \%$ & $1.49 \%$ \\
\hline
\end{tabular}

(Surface analysis up to a depth of $\sim 1 \mu \mathrm{m}$. Some of the $\mathrm{Cu}$ reading might have been a systems peak from the brass stage). 
Table 30: Results of analysis of X-ray spectrum of FIG. 58 (from spot 1 in FIG. 57) for the metallic elements only

\begin{tabular}{lrrr}
\multicolumn{5}{c}{ In number } & & \\
& of atoms & In mass & \multicolumn{2}{l}{ 位 mass } \\
$\mathrm{Cu}$ & $6.03 \%$ & $2.51 \%$ & $0.54 \%$ \\
$\mathrm{Pd}$ & $33.30 \%$ & $23.20 \%$ & $1.07 \%$ \\
$\mathrm{Ag}$ & $1.07 \%$ & $0.76 \%$ & $1.29 \%$ \\
$\mathrm{Cd}$ & $4.81 \%$ & $3.54 \%$ & $1.10 \%$ \\
$\mathrm{Pt}$ & $54.79 \%$ & $70.00 \%$ & $1.70 \%$
\end{tabular}

(Surface analysis up to a depth of $\sim 1 \mu \mathrm{m}$. Some of the $\mathrm{Cu}$ reading might have been a systems peak from the brass stage).

And when the X-ray acquisition spot was placed just outside the dark circular stain (spot 2), the presence of sulfur was diminished and the presence of cadmium was intensified.

The spectrum from spot 2 in FIG. 57 is shown in FIG. 59 and the results of its quantitative analysis are listed in Table 31.

Table 32 lists the results for the metallic elements: 
FIG. 59: Spectrum from spot 2 in FIG. 57.

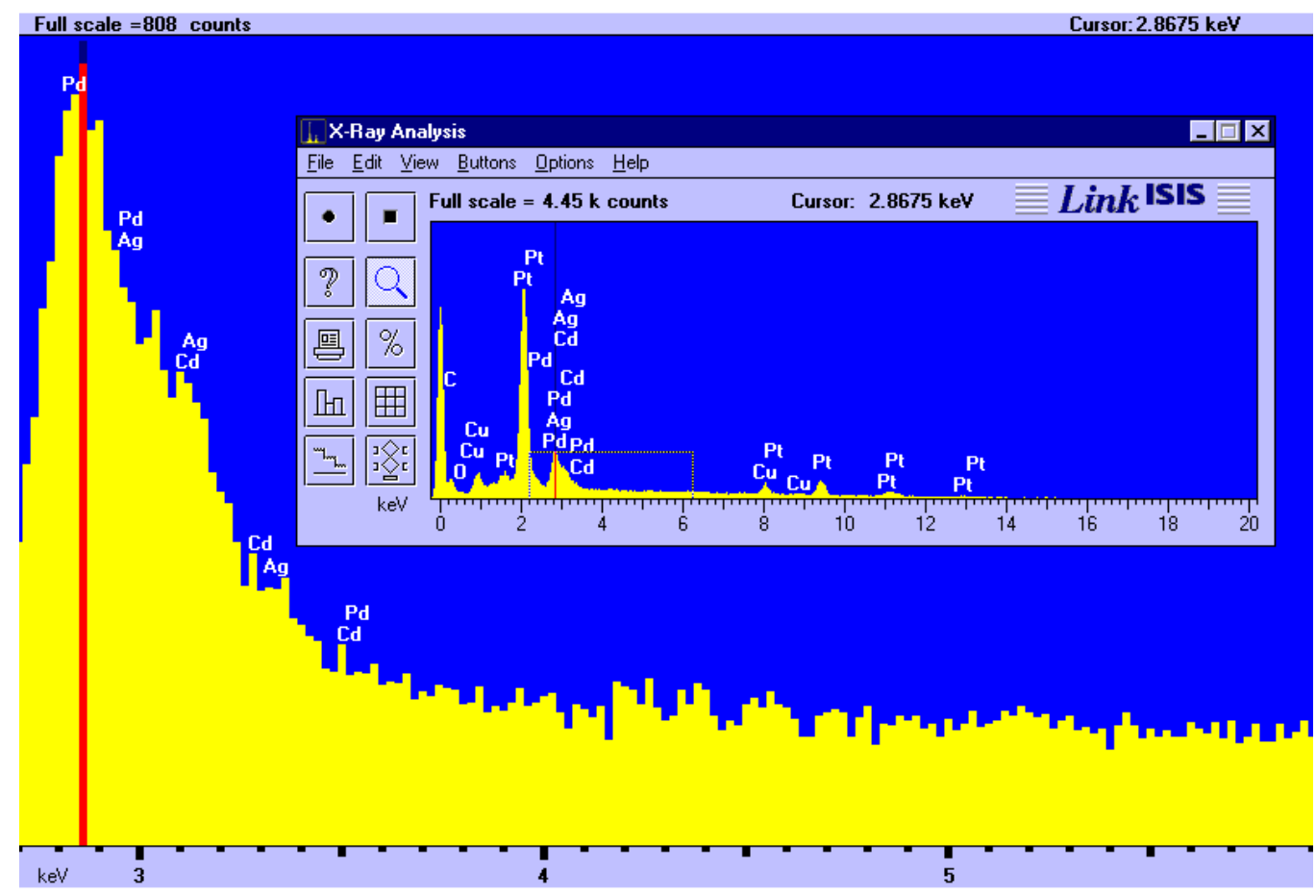

Table 31: Results of elemental analysis of X-ray spectrum of FIG. 59 (from spot 2 in FIG.

$57)$.

In number

Element of atoms In mass $\sigma_{\text {in mass }}$

$\begin{array}{lrrr}\mathrm{C} & 0.00 \% & 0.00 \% & 0.86 \% \\ \mathrm{O} & 0.00 \% & 0.00 \% & 0.70 \% \\ \mathrm{~S} & 1.36 \% & 0.30 \% & 0.36 \% \\ \mathrm{Cu} & 13.84 \% & 6.09 \% & 0.59 \% \\ \mathrm{Pd} & 25.39 \% & 18.71 \% & 1.01 \% \\ \mathrm{Ag} & 1.39 \% & 1.05 \% & 1.23 \% \\ \mathrm{Cd} & 7.97 \% & 6.21 \% & 1.08 \% \\ \mathrm{Pt} & 50.05 \% & 67.64 \% & 1.73 \%\end{array}$

(Surface analysis up to a depth of $\sim 1 \mu \mathrm{m}$. Some of the $\mathrm{Cu}$ reading might have been a systems peak from the brass stage). 
Table 32: Results of analysis of X-ray spectrum of FIG. 59 (from spot 2 in FIG. 57) for metallic elements.

\begin{tabular}{|c|c|c|c|}
\hline & $\begin{array}{l}\text { In number } \\
\text { of atoms }\end{array}$ & In mass & $\sigma_{\text {in mass }}$ \\
\hline $\mathrm{Cu}$ & $14.03 \%$ & $6.11 \%$ & $0.59 \%$ \\
\hline $\mathrm{Pd}$ & $25.74 \%$ & $18.77 \%$ & $1.01 \%$ \\
\hline $\mathrm{Ag}$ & $1.41 \%$ & $1.05 \%$ & $1.23 \%$ \\
\hline $\mathrm{Cd}$ & $8.08 \%$ & $6.22 \%$ & $1.09 \%$ \\
\hline $\mathrm{Pt}$ & $50.74 \%$ & $67.85 \%$ & $1.73 \%$ \\
\hline
\end{tabular}

(Surface analysis up to a depth of $\sim 1 \mu \mathrm{m}$. Some of the $\mathrm{Cu}$ reading might have been a systems peak from the brass stage).

A zone very near the corner of the $\mathrm{H}$ cell cathode where the granule-draped, bushlike-object-covered surface suddenly retreated had a remarkable abundance of cadmium.

In the surface layer of the $9 \mu \mathrm{m} \times 9 \mu \mathrm{m}$ area from which X-rays were taken, the abundance of cadmium actually rivaled that of palladium itself. According to SEMQuant, the number concentration of $\mathrm{Cd}$ was $8.89 \pm 1.59 \%$ while the number concentration of Pd locally was only $13.50 \pm 1.75 \%$.

The spectrum is shown in FIG. 60 and the results of the quantitative analysis are displayed in Table 33 (Table 34 for the metallic elements): 
FIG. 60: Spectrum from $9 \mu \mathrm{m} \times 9 \mu \mathrm{m}$ selected area on the bush-like-object-covered zone of the $\mathrm{H}$ cell cathode after electrolysis, right where the surface began to retreat to form the tip. This was the side opposite the spotweld, looking away from the anode.

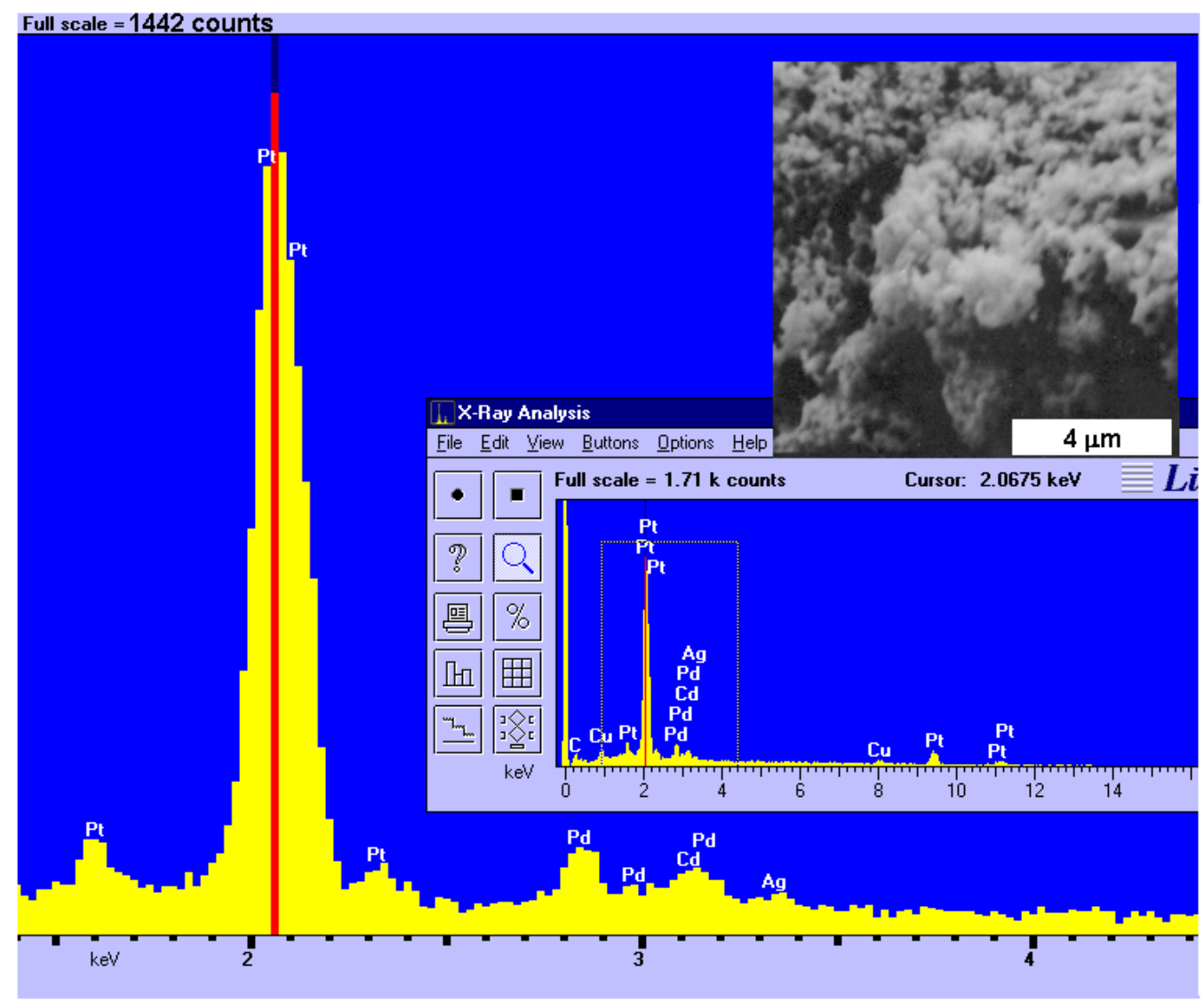

Table 33: Results of elemental analysis of X-ray spectrum of FIG. 60.

In number

\begin{tabular}{lrrr}
\multicolumn{2}{c}{ Element of atoms } & In mass & \multicolumn{2}{l}{$\sigma_{\text {in }}$ mass } \\
C & $90.01 \%$ & $40.36 \%$ & $0.84 \%$ \\
$\mathrm{O}$ & $0.00 \%$ & $0.00 \%$ & $0.85 \%$ \\
$\mathrm{~S}$ & $0.30 \%$ & $0.36 \%$ & $0.22 \%$ \\
$\mathrm{Cu}$ & $0.95 \%$ & $2.26 \%$ & $0.48 \%$ \\
$\mathrm{Pd}$ & $1.31 \%$ & $5.23 \%$ & $0.68 \%$ \\
$\mathrm{Ag}$ & $0.00 \%$ & $0.00 \%$ & $0.80 \%$ \\
$\mathrm{Cd}$ & $0.86 \%$ & $3.64 \%$ & $0.65 \%$ \\
$\mathrm{Pt}$ & $6.58 \%$ & $48.15 \%$ & $0.96 \%$
\end{tabular}


(Surface analysis up to a depth of $\sim 1 \mu \mathrm{m}$. Some of the $\mathrm{Cu}$ reading might have been a systems peak from the brass stage).

Table 34: Results of analysis of X-ray spectrum of FIG. 60 for metallic elements.

\begin{tabular}{|c|c|c|c|}
\hline & $\begin{array}{l}\text { In number } \\
\text { of atoms }\end{array}$ & In mass & $\sigma_{\text {in mass }}$ \\
\hline $\mathrm{Cu}$ & $9.76 \%$ & $3.81 \%$ & $0.81 \%$ \\
\hline $\mathrm{Pd}$ & $13.50 \%$ & $8.83 \%$ & $1.15 \%$ \\
\hline $\mathrm{Ag}$ & $0.00 \%$ & $0.00 \%$ & $1.35 \%$ \\
\hline $\mathrm{Cd}$ & $8.89 \%$ & $6.13 \%$ & $1.10 \%$ \\
\hline $\mathrm{Pt}$ & $67.86 \%$ & $81.23 \%$ & $1.62 \%$ \\
\hline
\end{tabular}

(Surface analysis up to a depth of $\sim 1 \mu \mathrm{m}$. Some of the $\mathrm{Cu}$ reading might have been a systems peak from the brass stage).

The X-ray spectrum from a $60 \mu \mathrm{m} \times 60 \mu \mathrm{m}$ area (FIG. 61) containing a curiouslooking pyramidal crystal, which was most likely contamination, did not show statistically significant levels of cadmium or silver in the few counts that were taken though it was clear that the signal was there.

The results of the quantitative analysis are listed in Table 35. If carbon was included in the analysis SEMQuant returned negative results for all the other elements, so in the analysis of Table 35 carbon was left out.

Table 36 lists the results for the metallic elements only. 
FIG. 61: Spectrum from pyramidal crystal on the $\mathrm{H}$ cell cathode after electrolysis, side opposite the spotweld (looking away from anode).

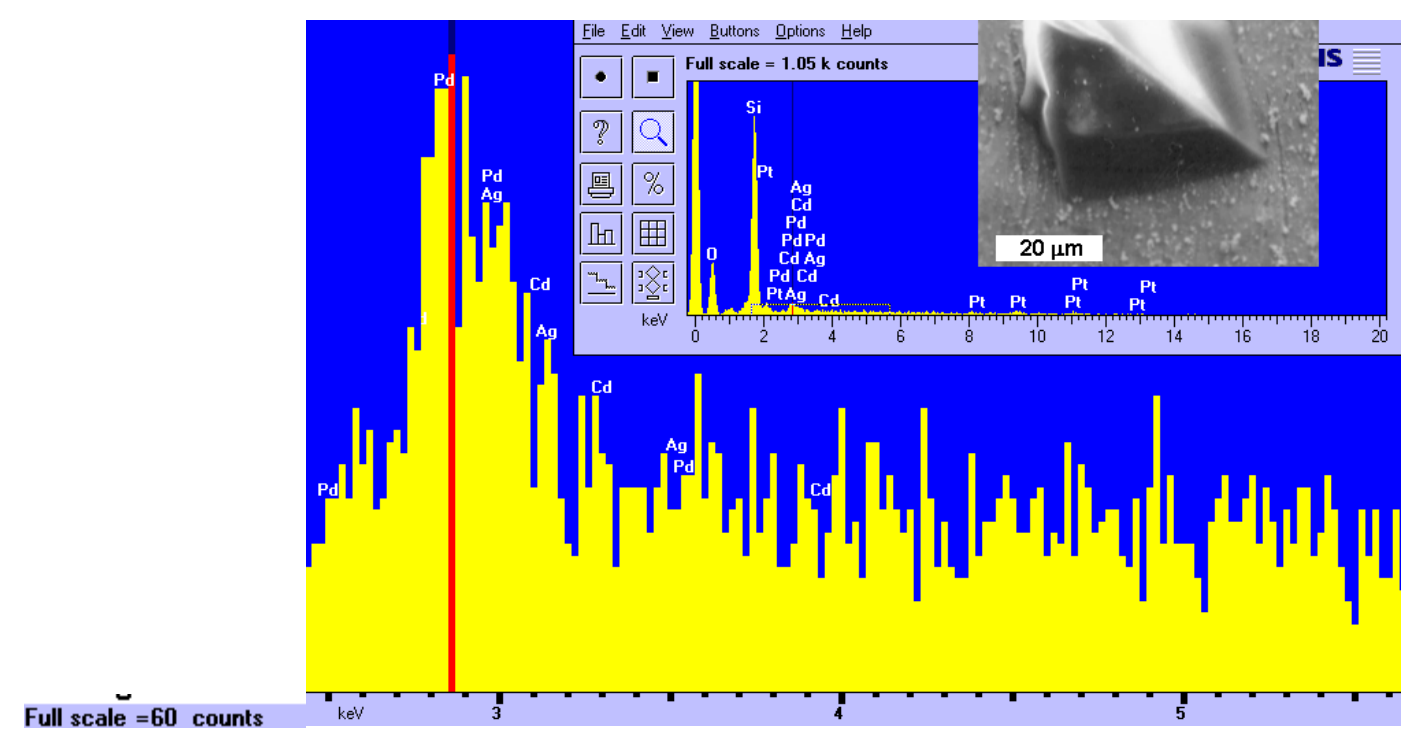

Table 35: Results of elemental analysis of spectrum of FIG. 61.

\begin{tabular}{lrrr} 
Element & $\begin{array}{r}\text { In number } \\
\text { of atoms }\end{array}$ & In mass & \multicolumn{1}{c}{ 但 mass } \\
$\mathrm{O}$ & $95.96 \%$ & $77.51 \%$ & $2.34 \%$ \\
$\mathrm{~S}$ & $1.23 \%$ & $2.00 \%$ & $0.35 \%$ \\
$\mathrm{Cu}$ & $0.39 \%$ & $1.25 \%$ & $0.60 \%$ \\
$\mathrm{Pd}$ & $0.93 \%$ & $4.97 \%$ & $1.37 \%$ \\
$\mathrm{Ag}$ & $0.10 \%$ & $0.55 \%$ & $1.58 \%$ \\
$\mathrm{Cd}$ & $0.00 \%$ & $0.00 \%$ & $1.38 \%$ \\
$\mathrm{Pt}$ & $1.39 \%$ & $13.73 \%$ & $1.14 \%$
\end{tabular}

(Surface analysis up to a depth of $\sim 1 \mu \mathrm{m}$. The $\mathrm{C}$ peak went off scale). 
Table 36: Results of analysis of spectrum of FIG. 61 for metallic elements only. An actual separate SEMQuant Analysis was conducted for these elements only.

\begin{tabular}{|c|c|c|c|}
\hline & $\begin{array}{l}\text { In number } \\
\text { of atoms }\end{array}$ & In mass & $\sigma_{\text {in mass }}$ \\
\hline $\mathrm{Cu}$ & $12.32 \%$ & $5.72 \%$ & $2.77 \%$ \\
\hline $\mathrm{Pd}$ & $42.51 \%$ & $33.08 \%$ & $7.94 \%$ \\
\hline $\mathrm{Ag}$ & $5.07 \%$ & $4.01 \%$ & $9.81 \%$ \\
\hline $\mathrm{Cd}$ & $0.00 \%$ & $0.00 \%$ & $8.91 \%$ \\
\hline $\mathrm{Pt}$ & $40.09 \%$ & $57.19 \%$ & $9.80 \%$ \\
\hline
\end{tabular}

(Surface analysis up to a depth of $\sim 1 \mu \mathrm{m}$ ).

FIG. 62 shows the X-ray spectrum from a $42 \mu \mathrm{m} \times 42 \mu \mathrm{m}$ selected area containing two narrow $\sim 10 \mu \mathrm{m}$ long crevices that were situated along the left edge of the $\mathrm{H}$ cell cathode on the side opposite the spotweld.

The results of the corresponding quantitative elemental analysis are listed in Table 37.

Table 38 lists the results for the metallic elements only.

There was over 1 atom of $\mathrm{Ag}$ for 3 of $\mathrm{Pd}$ and over 7 atoms of $\mathrm{Cd}$ for 10 of $\mathrm{Pd}$. 
FIG. 62: Spectrum from $42 \mu \mathrm{m} \times 42 \mu \mathrm{m}$ selected area containing crevices near edge of $\mathrm{H}$ cell cathode after electrolysis, side opposite the spotweld (looking away from anode).



Table 37: Results of elemental analysis of spectrum of FIG. 62

In number

\begin{tabular}{|c|c|c|c|}
\hline & atoms & mass & mass \\
\hline C & $44.72 \%$ & $12.12 \%$ & $0.50 \%$ \\
\hline $\mathrm{O}$ & $27.85 \%$ & $10.05 \%$ & $0.52 \%$ \\
\hline$S$ & $0.00 \%$ & $0.00 \%$ & $0.17 \%$ \\
\hline $\mathrm{Cu}$ & $11.09 \%$ & $15.90 \%$ & $0.66 \%$ \\
\hline $\mathrm{Pd}$ & $2.43 \%$ & $5.84 \%$ & $0.56 \%$ \\
\hline $\mathrm{Ag}$ & $0.92 \%$ & $2.24 \%$ & $0.66 \%$ \\
\hline $\mathrm{Cd}$ & $1.79 \%$ & $4.53 \%$ & $0.56 \%$ \\
\hline $\mathrm{Pt}$ & $11.21 \%$ & $49.33 \%$ & $0.84 \%$ \\
\hline
\end{tabular}

(Surface analysis up to a depth of $\sim 1 \mu \mathrm{m}$. Some of the $\mathrm{Cu}$ reading might have been a systems peak from the brass stage). 
Table 38: Results of analysis of spectrum of FIG. 62 for metallic elements

\begin{tabular}{lrrr}
\multicolumn{5}{c}{ In number } & & \\
& of atoms & In mass & \multicolumn{2}{c}{$\sigma_{\text {in }}$ mass } \\
$\mathrm{Cu}$ & $40.42 \%$ & $20.43 \%$ & $0.85 \%$ \\
$\mathrm{Pd}$ & $8.85 \%$ & $7.50 \%$ & $0.72 \%$ \\
$\mathrm{Ag}$ & $3.35 \%$ & $2.88 \%$ & $0.85 \%$ \\
$\mathrm{Cd}$ & $6.52 \%$ & $5.82 \%$ & $0.72 \%$ \\
$\mathrm{Pt}$ & $40.86 \%$ & $63.38 \%$ & $1.08 \%$
\end{tabular}

(Surface analysis up to a depth of $\sim 1 \mu \mathrm{m}$. Some of the $\mathrm{Cu}$ reading might have been a systems peak from the brass stage).

There was a tiny circular cave at the very corner of the lower tip of the $\mathrm{H}$ cell cathode. The feature is shown in FIG. 63. X-rays were collected from an $8 \mu \mathrm{m} \times 8$ $\mu \mathrm{m}$ selected area encompassing this cavity. The spectrum is displayed in FIG. 64.

Analysis of the spectrum revealed $1.23 \pm 0.76 \%$ of cadmium and $6.61 \pm 1.26 \%$ of silver for only $29.43 \pm 1.28 \%$ of palladium in number of atoms according to the software. The X-ray spectrum clearly shows the combined $\mathrm{Ag} \mathrm{L}_{\alpha}+\mathrm{Pd}_{\beta}$ peaks at 2.984-2.99 $\mathrm{keV}$ rising to $68 \%$ the height of the main $\mathrm{Pd} \mathrm{L} \alpha$ peak at $2.839 \mathrm{keV}$. (If no Ag had been present, this height would have been only 40\%). Also, the slight bump at $3.133-3.15 \mathrm{keV}$ on the right slope of the combined $\mathrm{Ag} \mathrm{L}_{\alpha}+\operatorname{Pd} \mathrm{L}_{\beta}$ promontory due to the overlapped presence of $\mathrm{Ag} \mathrm{L}_{\beta}$ and $\mathrm{Cd} \mathrm{L}_{\alpha}$ was discernible.

The SEMQuant analysis results are listed in Table 39. Table 40 lists the results for the metallic elements only: 
FIG. 63: Tiny circular cave at the corner of the lower tip of the $\mathrm{H}$ cell cathode after electrolysis, side opposite the spotweld (looking away from anode).

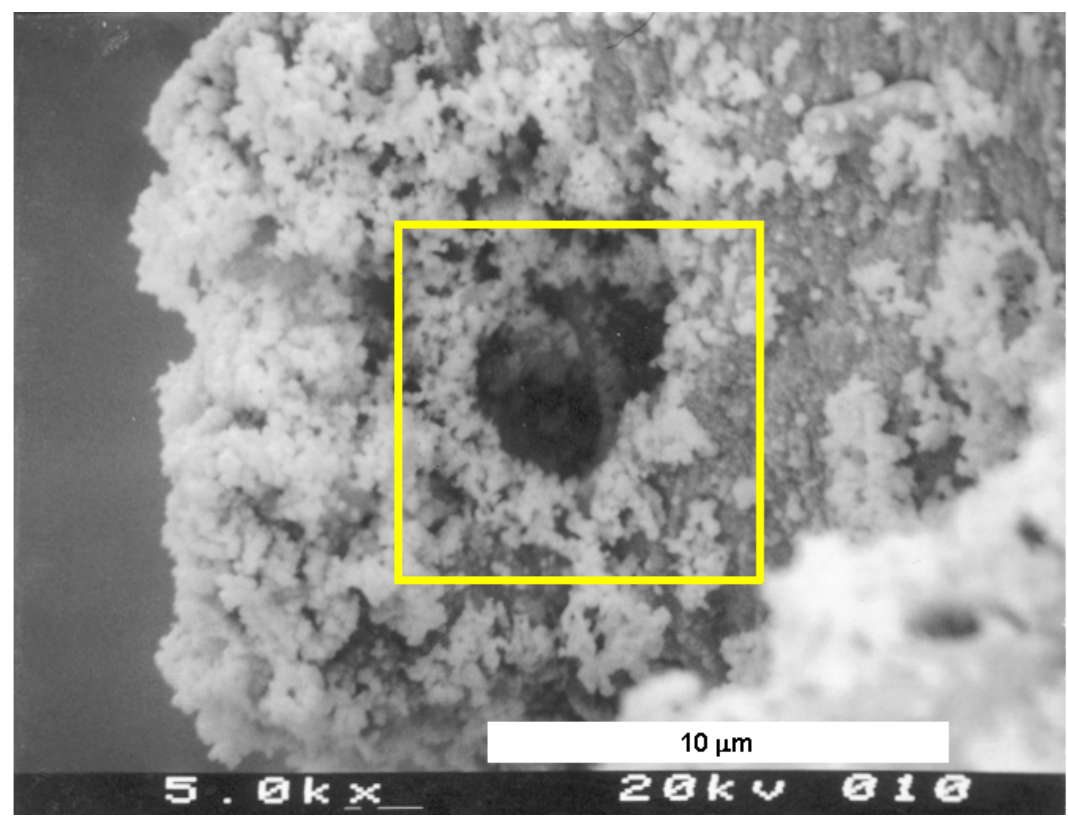

FIG. 64: X-ray spectrum from $8 \mu \mathrm{m} \times 8 \mu \mathrm{m}$ selected area in FIG. 63.

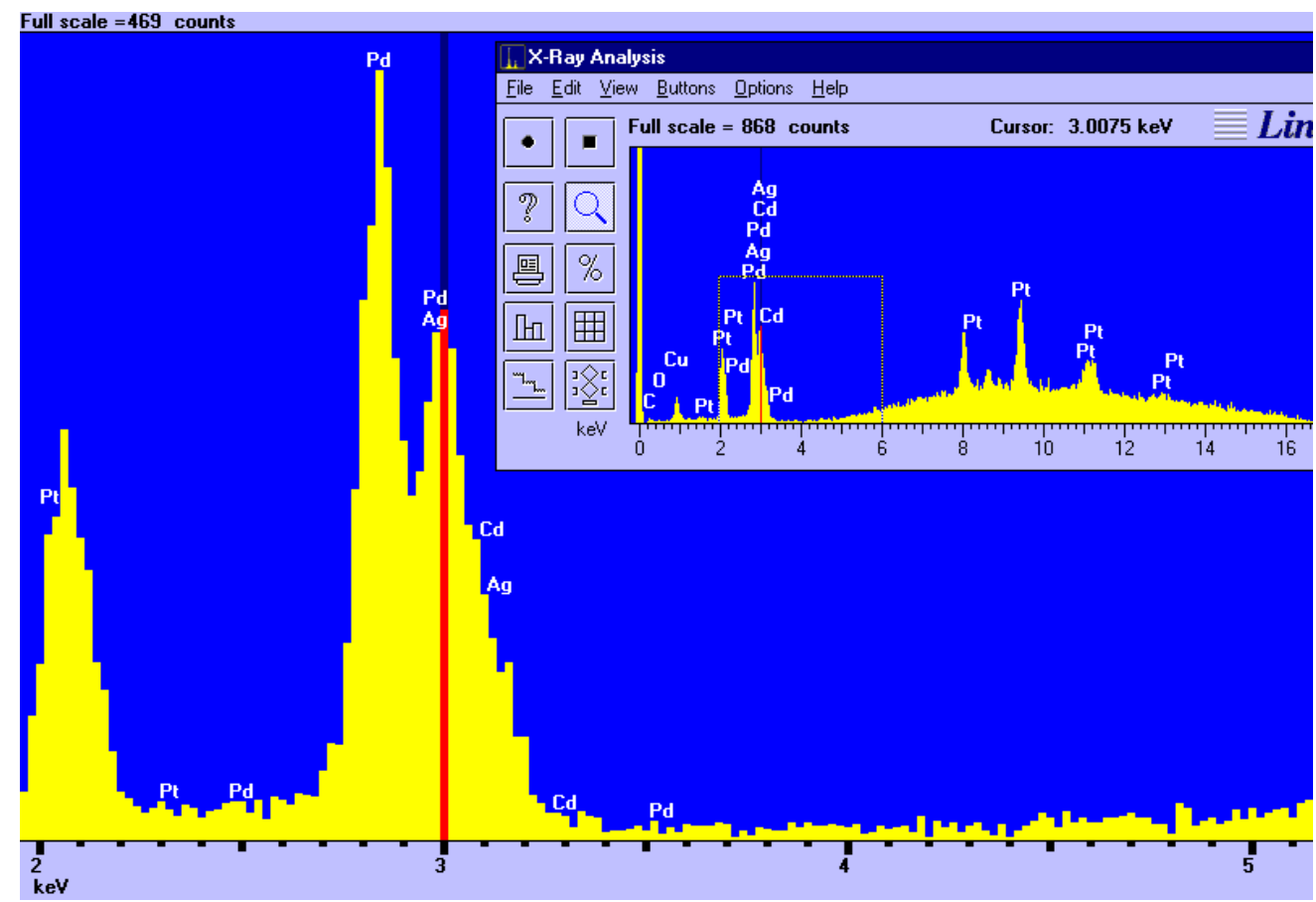


Table 39: Results of elemental analysis of spectrum of FIG. 64, from selected area in FIG.

63.

\begin{tabular}{|c|c|c|c|}
\hline & In number & & \\
\hline Element & of atoms & In mass & $\sigma_{\text {in }}$ mass \\
\hline C & $11.79 \%$ & $1.67 \%$ & $0.42 \%$ \\
\hline O & $1.72 \%$ & $0.32 \%$ & $0.61 \%$ \\
\hline$S$ & $0.40 \%$ & $0.15 \%$ & $0.19 \%$ \\
\hline $\mathrm{Cu}$ & $39.75 \%$ & $29.86 \%$ & $1.92 \%$ \\
\hline $\mathrm{Pd}$ & $29.43 \%$ & $37.01 \%$ & $1.62 \%$ \\
\hline $\mathrm{Ag}$ & $6.61 \%$ & $8.42 \%$ & $1.61 \%$ \\
\hline $\mathrm{Cd}$ & $1.23 \%$ & $1.63 \%$ & $1.02 \%$ \\
\hline $\mathrm{Pt}$ & $9.08 \%$ & $20.93 \%$ & $1.06 \%$ \\
\hline
\end{tabular}

(Surface analysis up to a depth of $\sim 1 \mu \mathrm{m}$. Some of the $\mathrm{Cu}$ reading might have been a systems peak from the brass stage).

Table 40: Results of analysis of spectrum of FIG. 64, from selected area in FIG. 63, for the metallic elements

\begin{tabular}{lrrr}
\multicolumn{5}{c}{$\begin{array}{l}\text { In number } \\
\text { of atoms }\end{array}$} & In mass & \multicolumn{2}{c}{$\sigma_{\text {in }}$ mass } \\
$\mathrm{Cu}$ & $46.17 \%$ & $30.52 \%$ & $1.96 \%$ \\
$\mathrm{Pd}$ & $34.18 \%$ & $37.82 \%$ & $1.66 \%$ \\
$\mathrm{Ag}$ & $7.68 \%$ & $8.61 \%$ & $1.65 \%$ \\
$\mathrm{Cd}$ & $1.43 \%$ & $1.67 \%$ & $1.04 \%$ \\
$\mathrm{Pt}$ & $10.55 \%$ & $21.39 \%$ & $1.08 \%$
\end{tabular}

(Surface analysis up to a depth of $\sim 1 \mu \mathrm{m}$. Some of the $\mathrm{Cu}$ reading might have been a systems peak from the brass stage).

X-rays were then taken from a $0.6 \mathrm{~mm} \times 0.6 \mathrm{~mm}$ acquisition area that included the whole corner region of this side of the $\mathrm{H}$ cathode opposite the spotweld (FIG. 65). The spectrum is shown in FIG. 66. 
There was no silver, but the signature of cadmium was unmistakable, and at low count rates the software occasionally had difficulty in distinguishing between cadmium and silver as their signals so closely overlapped.

According to SEMQuant, there was over 1 atom of $\mathrm{Cd}$ for 9 of Pd.

The full results of the SEMQuant analysis of the spectrum from this area are listed in Table 41. Table 42 lists the results for the metallic elements only:

FIG. 65: Micrograph of corner of cathode of the $\mathrm{H}$ cell after electrolysis at the lower tip, side opposite the spotweld (looking away from the anode).

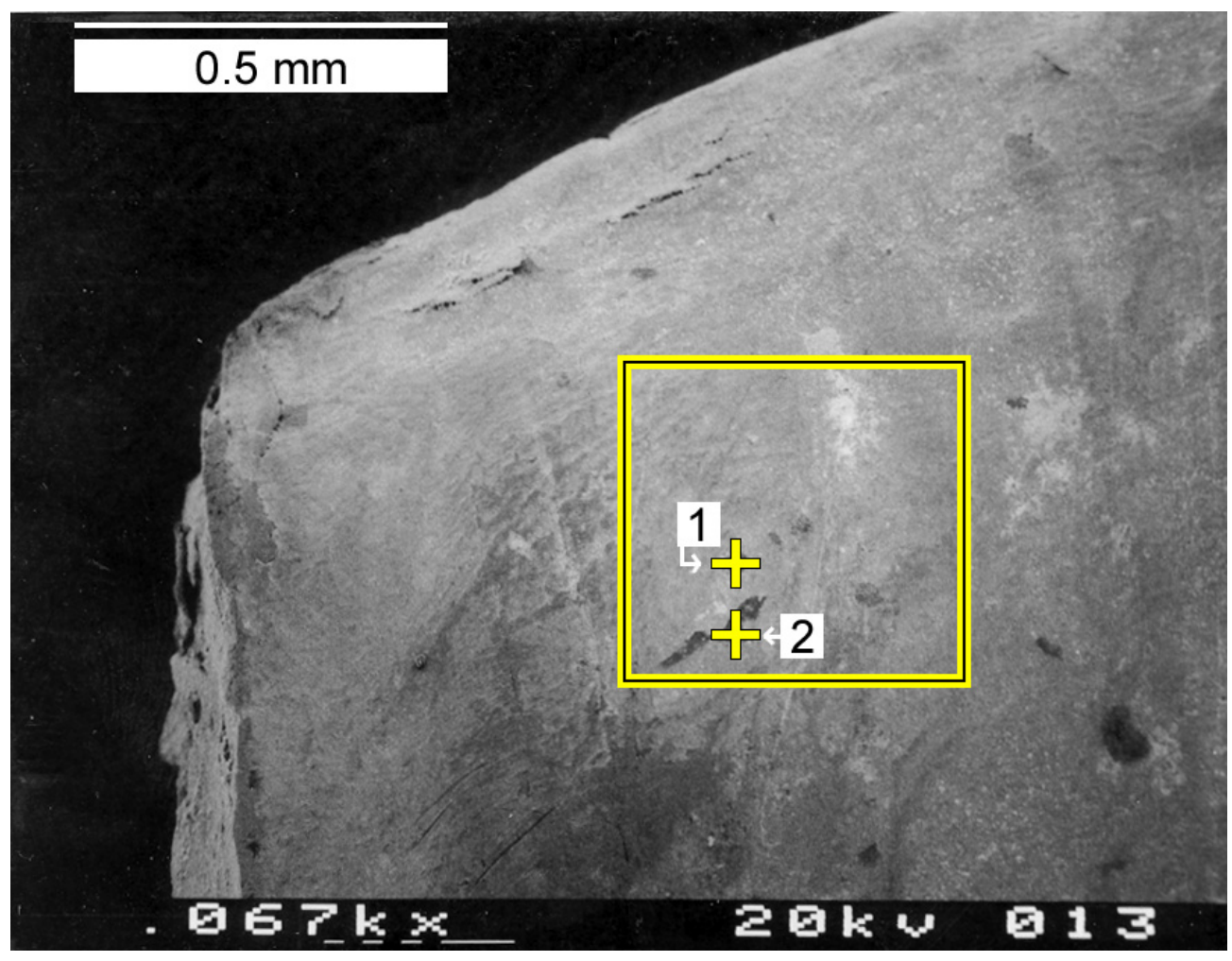


FIG. 66: X-ray spectrum from $0.6 \mathrm{~mm}$ x $0.6 \mathrm{~mm}$ selected area in FIG. 65.

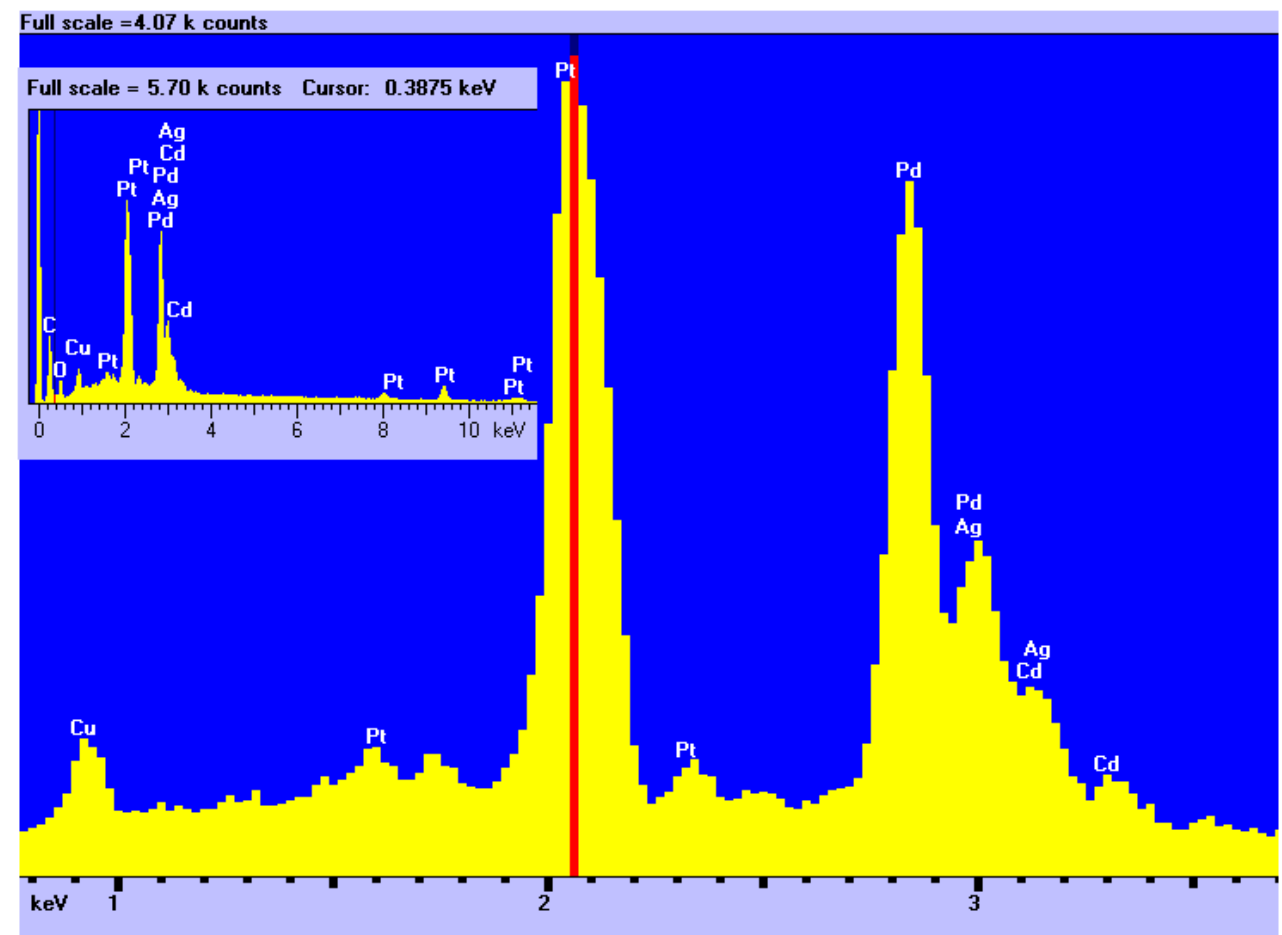

Table 41: Results of elemental analysis of spectrum of FIG. 66.

In number

\begin{tabular}{|c|c|c|c|}
\hline & atoms & mass & mass \\
\hline C & $57.46 \%$ & $17.35 \%$ & $0.31 \%$ \\
\hline 0 & $19.89 \%$ & $8.00 \%$ & $0.43 \%$ \\
\hline & $0.39 \%$ & $0.32 \%$ & $0.10 \%$ \\
\hline & $1.30 \%$ & $2.08 \%$ & $0.24 \%$ \\
\hline & $12.31 \%$ & $32.92 \%$ & $0.51 \%$ \\
\hline & $0.00 \%$ & $0.00 \%$ & $0.59 \%$ \\
\hline 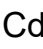 & $1.50 \%$ & $4.24 \%$ & $0.41 \%$ \\
\hline & $7.16 \%$ & $35.10 \%$ & $0.46 \%$ \\
\hline
\end{tabular}

(Surface analysis up to a depth of $\sim 1 \mu \mathrm{m}$. Some of the $\mathrm{Cu}$ reading might have been a systems peak from the brass stage). 
Table 42: Results of analysis of spectrum of FIG. 66, for the metallic elements.

\begin{tabular}{lrrr}
\multicolumn{5}{c}{ In number } & & \\
& of atoms & In mass & \multicolumn{2}{l}{ 位 } \\
& $5.84 \%$ & $2.80 \%$ & $0.32 \%$ \\
$\mathrm{Cu}$ & $55.28 \%$ & $44.29 \%$ & $0.69 \%$ \\
$\mathrm{Pd}$ & $0.00 \%$ & $0.00 \%$ & $0.79 \%$ \\
$\mathrm{Ag}$ & $6.74 \%$ & $5.70 \%$ & $0.55 \%$ \\
$\mathrm{Cd}$ & $32.15 \%$ & $47.22 \%$ & $0.62 \%$ \\
$\mathrm{Pt}$ & & &
\end{tabular}

(Surface analysis up to a depth of $\sim 1 \mu \mathrm{m}$. Some of the $\mathrm{Cu}$ reading might have been a systems peak from the brass stage).

X-rays were then acquired from two spots on dark patches in the selected area of FIG. 65. The results were similar, perhaps with even a little more cadmium.

The spectrum from spot 1 is shown in FIG. 67 and the results of its SEMQuant analysis are displayed in Table 43 (Table 44 for the metallic elements).

The spectrum from spot 2 is shown in FIG. 68 and the results of its SEMQuant analysis are listed in Table 45 (Table 46 for the metallic elements): 
FIG. 67: X-ray spectrum from spot 1 in FIG. 65.

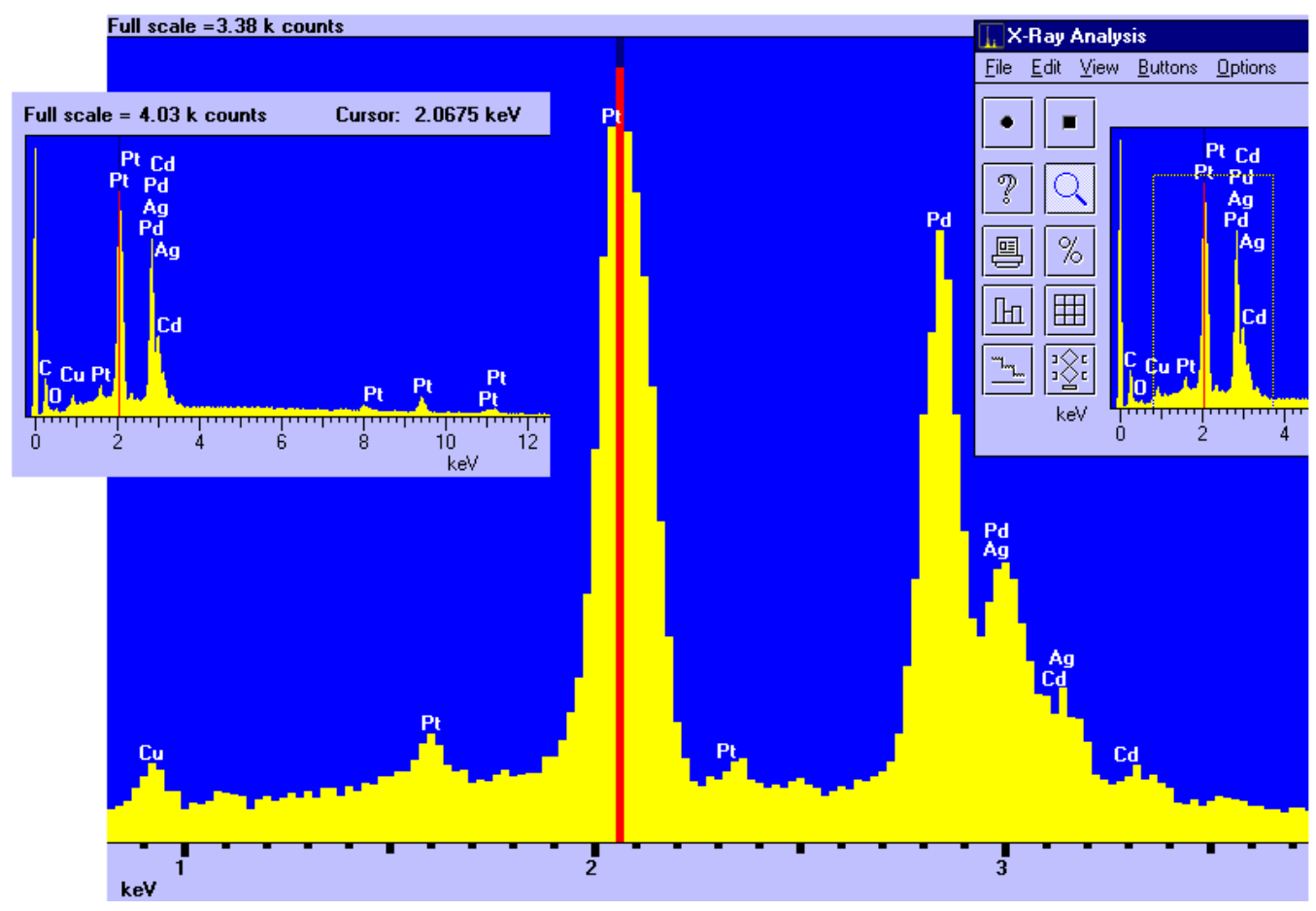

Table 43: Results of elemental analysis of spectrum of FIG. 67, from spot 1 in FIG. 65.

\begin{tabular}{lrrr}
\multicolumn{5}{c}{ In number } \\
of atoms & In mass & \multicolumn{2}{c}{ 作 } \\
& $54.73 \%$ & $10.51 \%$ & $0.29 \%$ \\
$\mathrm{C}$ & $4.06 \%$ & $1.04 \%$ & $0.40 \%$ \\
$\mathrm{O}$ & $0.04 \%$ & $0.02 \%$ & $0.13 \%$ \\
$\mathrm{~S}$ & $2.00 \%$ & $2.03 \%$ & $0.33 \%$ \\
$\mathrm{Cu}$ & $22.69 \%$ & $38.57 \%$ & $0.66 \%$ \\
$\mathrm{Pd}$ & $0.14 \%$ & $0.24 \%$ & $0.78 \%$ \\
$\mathrm{Ag}$ & $2.51 \%$ & $4.50 \%$ & $0.52 \%$ \\
$\mathrm{Cd}$ & $13.83 \%$ & $43.09 \%$ & $0.66 \%$ \\
$\mathrm{Pt}$ & & &
\end{tabular}

(Surface analysis up to a depth of $\sim 1 \mu \mathrm{m}$. Some of the $\mathrm{Cu}$ reading might have been a systems peak from the brass stage). 
Table 44: Results of analysis of spectrum of FIG. 67, from spot 1 in FIG. 65, for the metallic elements

\begin{tabular}{lrrr}
\multicolumn{5}{c}{$\begin{array}{l}\text { In number } \\
\text { of atoms }\end{array}$} & & \\
& In mass & \multicolumn{2}{l}{$\sigma_{\text {in }}$ mass } \\
$\mathrm{Cu}$ & $4.86 \%$ & $2.30 \%$ & $0.37 \%$ \\
$\mathrm{Pd}$ & $55.11 \%$ & $43.62 \%$ & $0.75 \%$ \\
$\mathrm{Ag}$ & $0.34 \%$ & $0.27 \%$ & $0.88 \%$ \\
$\mathrm{Cd}$ & $6.10 \%$ & $5.09 \%$ & $0.59 \%$ \\
$\mathrm{Pt}$ & $33.59 \%$ & $48.73 \%$ & $0.75 \%$
\end{tabular}

(Surface analysis up to a depth of $\sim 1 \mu \mathrm{m}$. Some of the $\mathrm{Cu}$ reading might have been a systems peak from the brass stage).

FIG. 68: X-ray spectrum from spot 2 in FIG. 65.

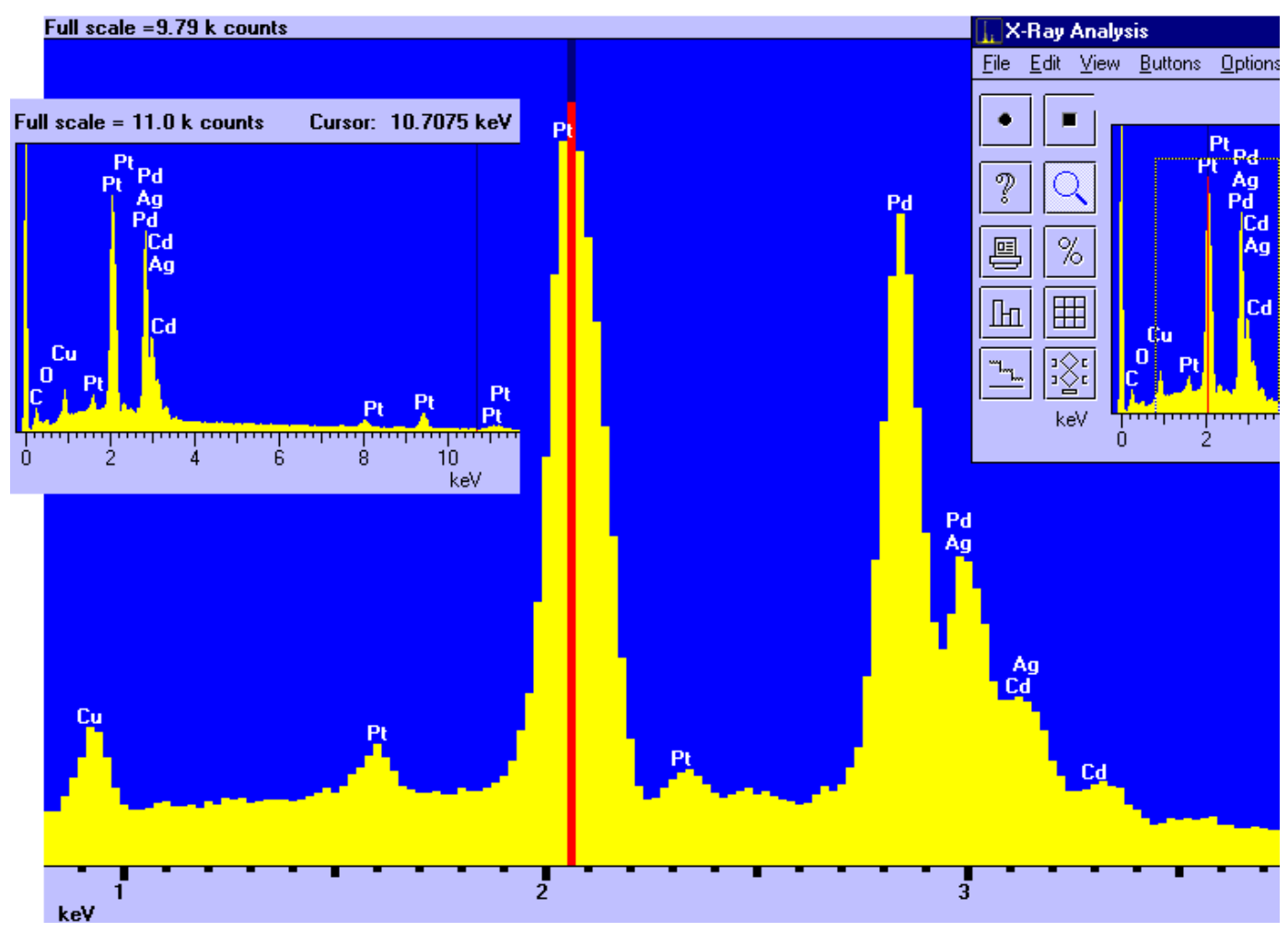


Table 45: Results of elemental analysis of spectrum of FIG. 68, from spot 2 in FIG. 65.

\begin{tabular}{lrrr}
\multicolumn{5}{c}{$\begin{array}{l}\text { In number } \\
\text { of atoms }\end{array}$} & In mass & \multicolumn{2}{l}{ 更 mass } \\
C & $37.83 \%$ & $5.82 \%$ & $0.15 \%$ \\
$\mathrm{O}$ & $6.73 \%$ & $1.38 \%$ & $0.27 \%$ \\
$\mathrm{~S}$ & $0.74 \%$ & $0.31 \%$ & $0.08 \%$ \\
$\mathrm{Cu}$ & $3.40 \%$ & $2.76 \%$ & $0.19 \%$ \\
$\mathrm{Pd}$ & $30.45 \%$ & $41.48 \%$ & $0.42 \%$ \\
$\mathrm{Ag}$ & $0.00 \%$ & $0.00 \%$ & $0.49 \%$ \\
$\mathrm{Cd}$ & $3.61 \%$ & $5.19 \%$ & $0.33 \%$ \\
$\mathrm{Pt}$ & $17.24 \%$ & $43.06 \%$ & $0.41 \%$
\end{tabular}

(Surface analysis up to a depth of $\sim 1 \mu \mathrm{m}$. Some of the $\mathrm{Cu}$ reading might have been a systems peak from the brass stage).

Table 46: Results of analysis of spectrum of FIG. 68, from spot 2 in FIG. 65, for the metallic elements only

\begin{tabular}{lrrr}
\multicolumn{5}{c}{ In number } & & \\
& of atoms & In mass & \multicolumn{1}{c}{$\sigma_{\text {in }}$ mass } \\
$\mathrm{Cu}$ & $6.21 \%$ & $2.98 \%$ & $0.21 \%$ \\
$\mathrm{Pd}$ & $55.67 \%$ & $44.84 \%$ & $0.45 \%$ \\
$\mathrm{Ag}$ & $0.00 \%$ & $0.00 \%$ & $0.53 \%$ \\
$\mathrm{Cd}$ & $6.59 \%$ & $5.61 \%$ & $0.36 \%$ \\
$\mathrm{Pt}$ & $31.53 \%$ & $46.56 \%$ & $0.44 \%$
\end{tabular}

(Surface analysis up to a depth of $\sim 1 \mu \mathrm{m}$. Some of the $\mathrm{Cu}$ reading might have been a systems peak from the brass stage).

The $\mathrm{H}$ cell cathode was then flipped to the other side, the side of the spotweld (which had been facing the anode during electrolysis), and X-rays were collected from a $5 \mu \mathrm{m} \times 5 \mu \mathrm{m}$ area touching the lower tip, $2.1 \mathrm{~mm}$ from the left corner and 3 $\mathrm{mm}$ from the right corner as seen in the microscope, where the tip was on top (FIG. 69). 
The area selected for X-ray collection was at the edge of a zone covered with $\sim 1$ $\mu \mathrm{m}$ sized flakes, just before the surface receded to end in the tip. The X-ray spectrum is displayed in FIG. 70 and the results of the SEMQuant analysis are listed in Table 47 (Table 48 lists the results for the metallic elements only).

The number abundance of cadmium was $13.82 \pm 1.49 \%$ and the number abundance of silver was $7.26 \pm 2.1 \%$, relative to palladium:

FIG. 69: Micrograph of area along the tip of the $\mathrm{H}$ cell cathode after electrolysis, side of the spotweld (facing the anode).

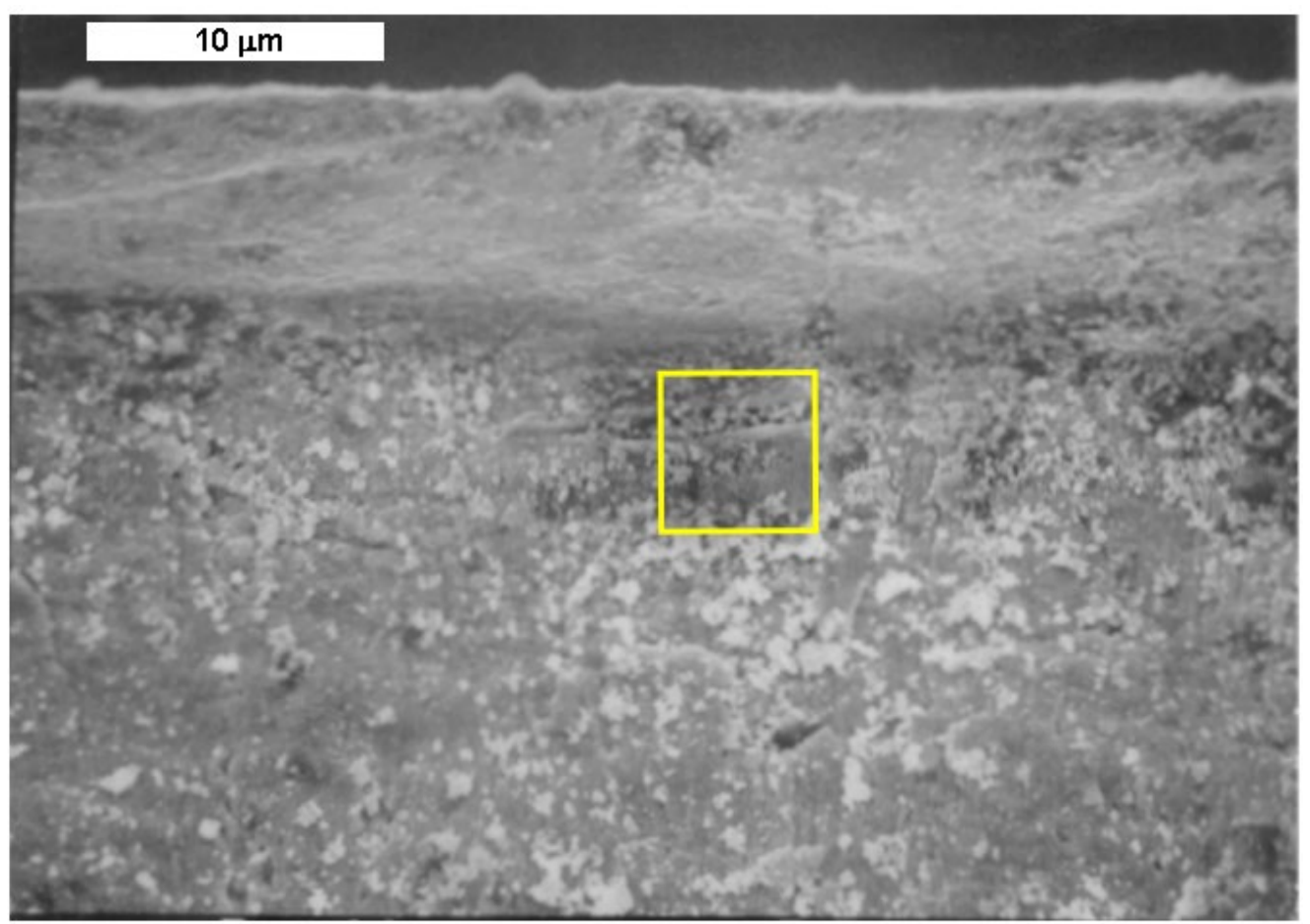


FIG. 70: X-ray spectrum from $5 \mu \mathrm{m} \times 5 \mu \mathrm{m}$ selected area in FIG. 69.

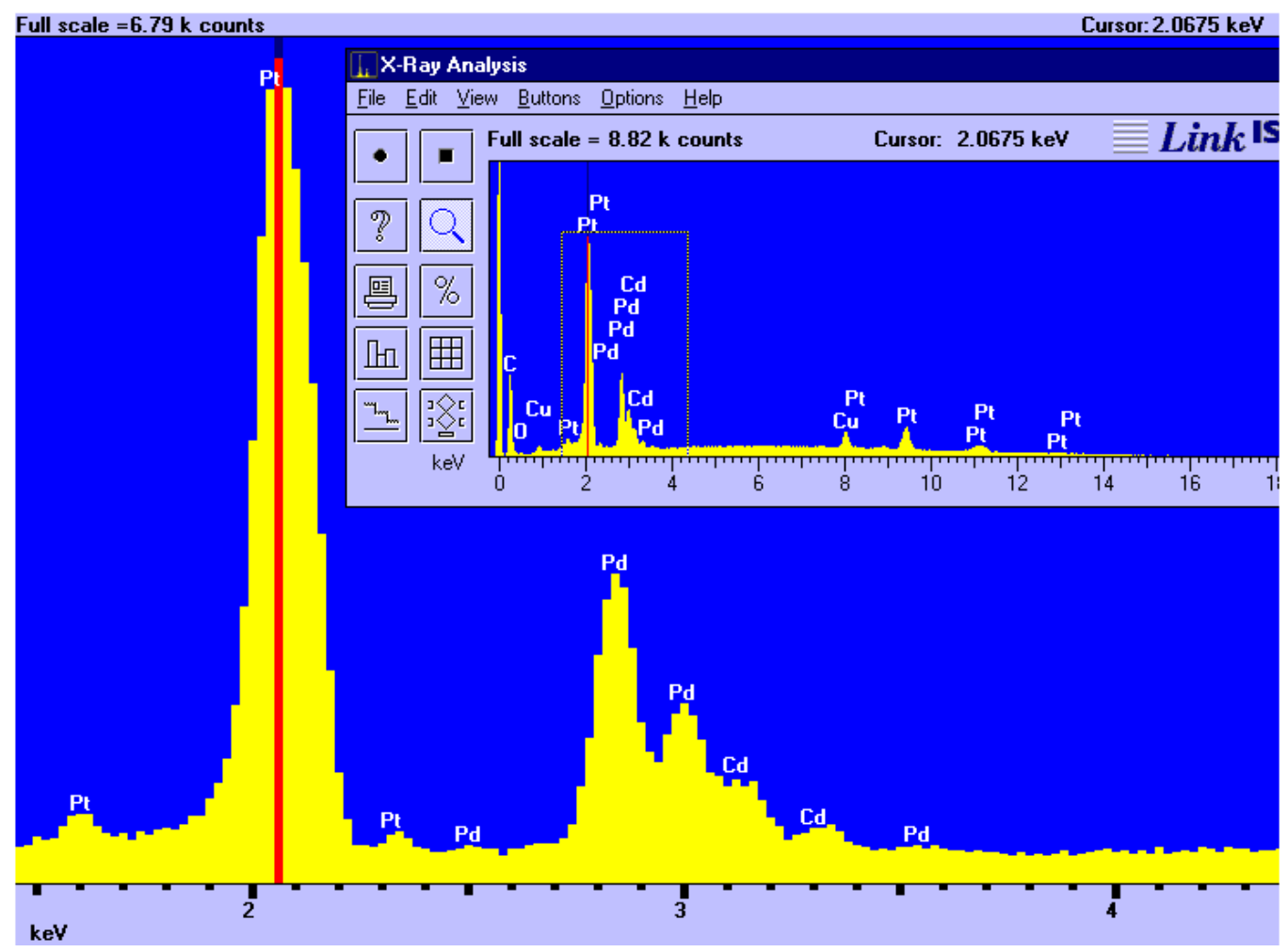

Table 47: Results of elemental analysis of spectrum of FIG. 70, from selected area in FIG.

69.

\begin{tabular}{lrrr}
\multicolumn{5}{c}{ In number } & & \\
\multicolumn{5}{c}{ of atoms } & In mass & \multicolumn{2}{l}{ 位 } \\
& $78.84 \%$ & $26.85 \%$ & $0.31 \%$ \\
$\mathrm{C}$ & $2.29 \%$ & $1.04 \%$ & $0.21 \%$ \\
$\mathrm{O}$ & $0.00 \%$ & $0.00 \%$ & $0.08 \%$ \\
$\mathrm{~S}$ & $3.60 \%$ & $6.48 \%$ & $0.30 \%$ \\
$\mathrm{Cu}$ & $6.23 \%$ & $18.80 \%$ & $0.34 \%$ \\
$\mathrm{Pd}$ & $0.46 \%$ & $1.41 \%$ & $0.41 \%$ \\
$\mathrm{Ag}$ & $0.87 \%$ & $2.77 \%$ & $0.30 \%$ \\
$\mathrm{Cd}$ & $7.71 \%$ & $42.65 \%$ & $0.39 \%$ \\
$\mathrm{Pt}$ & & &
\end{tabular}

(Surface analysis up to a depth of $\sim 1 \mu \mathrm{m}$. Some of the $\mathrm{Cu}$ reading might have been a systems peak from the brass stage). 
Table 48: Results of analysis of spectrum of FIG. 70, from selected area in FIG. 69, for the metallic elements. An actual separate SEMQuant analysis was conducted for these elements only.

\begin{tabular}{lrrr}
\multicolumn{5}{c}{ In number } & & \\
& of atoms & In mass & \multicolumn{2}{c}{$\sigma_{\text {in }}$ mass } \\
$\mathrm{Cu}$ & $17.90 \%$ & $8.40 \%$ & $0.38 \%$ \\
$\mathrm{Pd}$ & $34.00 \%$ & $26.72 \%$ & $0.46 \%$ \\
$\mathrm{Ag}$ & $2.47 \%$ & $1.97 \%$ & $0.57 \%$ \\
$\mathrm{Cd}$ & $4.70 \%$ & $3.90 \%$ & $0.42 \%$ \\
$\mathrm{Pt}$ & $40.93 \%$ & $59.01 \%$ & $0.61 \%$
\end{tabular}

(Surface analysis up to a depth of $\sim 1 \mu \mathrm{m}$. Some of the $\mathrm{Cu}$ reading might have been a systems peak from the brass stage).

X-rays were then collected from a $2.3 \mathrm{~mm} \times 2.3 \mathrm{~mm}$ representative area on the $\mathrm{H}$ cathode spotweld side, which was facing the anode. The micrograph of the region with the selected area is shown in FIG. 71 and the X-ray spectrum from the selected area is shown in FIG. 72. The analysis of this spectrum corroborated again that cadmium was there and in amounts that seemed to be slightly higher than on the other side which had been looking away from the anode. The $\mathrm{Cd}$ number concentration $5.49 \pm 0.52 \%$ relative to $\mathrm{Pd}$ can be contrasted with the number concentration $4.40 \pm 0.71 \%$ in the spectrum of FIG. 56, over a selected area of similar size. The results of the analysis are listed in Table 49. Table 50 lists the results for the metallic elements. On this selected area in FIG. 71, there was over 1 atom of $\mathrm{Cd}$ for 19 of $\mathrm{Pd}$ : 
FIG. 71: Micrograph of area along the edge of the $\mathrm{H}$ cell cathode after electrolysis, side of the spotweld facing the anode. It shows the $1.6 \mathrm{~mm} \times 1.6 \mathrm{~mm}$ selected area from which $\mathrm{X}$ rays were acquired.



FIG. 72: X-ray spectrum from selected area in FIG. 71:

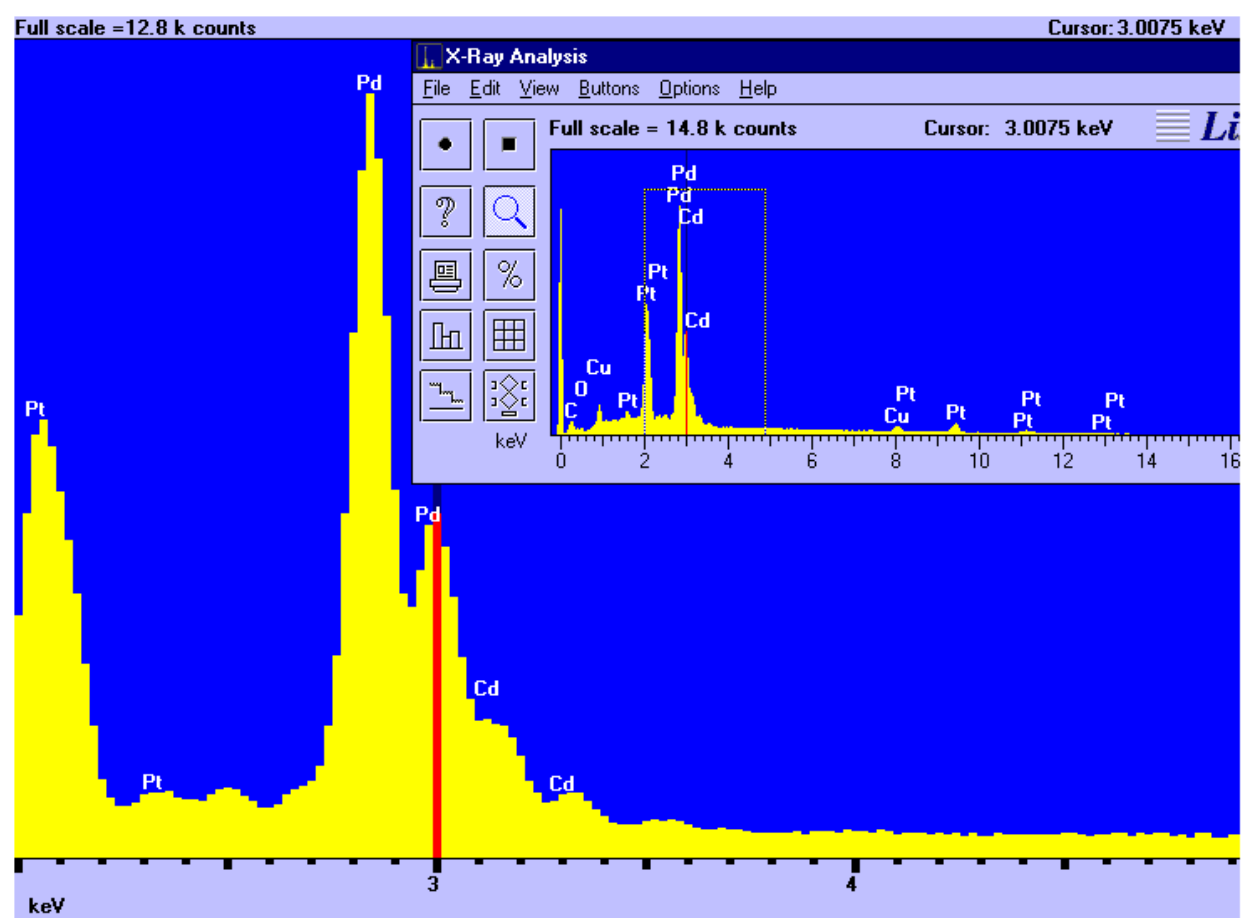


Table 49: Results of elemental analysis of spectrum of FIG. 72, from selected area in FIG.

71

\begin{tabular}{lrrr}
\multicolumn{5}{c}{ In number } & & \\
\multicolumn{5}{c}{ of atoms } & In mass & \multicolumn{2}{l}{ 位 } \\
mass \\
$\mathrm{C}$ & $30.78 \%$ & $4.35 \%$ & $0.12 \%$ \\
$\mathrm{O}$ & $2.61 \%$ & $0.49 \%$ & $0.26 \%$ \\
$\mathrm{~S}$ & $0.40 \%$ & $14.96 \%$ & $0.07 \%$ \\
$\mathrm{Cu}$ & $3.74 \%$ & $2.79 \%$ & $0.19 \%$ \\
$\mathrm{Pd}$ & $46.61 \%$ & $58.31 \%$ & $0.48 \%$ \\
$\mathrm{Ag}$ & $0.00 \%$ & $0.00 \%$ & $0.50 \%$ \\
$\mathrm{Cd}$ & $2.56 \%$ & $3.38 \%$ & $0.32 \%$ \\
$\mathrm{Pt}$ & $13.30 \%$ & $30.52 \%$ & $0.33 \%$
\end{tabular}

(Surface analysis up to a depth of $\sim 1 \mu \mathrm{m}$. Some of the $\mathrm{Cu}$ reading might have been a systems peak from the brass stage).

Table 50: Results of analysis of spectrum of FIG. 72, from selected area in FIG. 71, for the metallic elements. An actual separate SEMQuant analysis was conducted for these elements only.

\begin{tabular}{lrrr}
\multicolumn{5}{c}{ In number } & & \\
& of atoms & In mass & \multicolumn{1}{l}{ 作 mass } \\
$\mathrm{Cu}$ & $5.60 \%$ & $2.92 \%$ & $0.19 \%$ \\
$\mathrm{Pd}$ & $70.48 \%$ & $61.46 \%$ & $0.49 \%$ \\
$\mathrm{Ag}$ & $0.00 \%$ & $0.00 \%$ & $0.53 \%$ \\
$\mathrm{Cd}$ & $3.87 \%$ & $3.56 \%$ & $0.34 \%$ \\
$\mathrm{Pt}$ & $20.05 \%$ & $32.05 \%$ & $0.34 \%$
\end{tabular}

(Surface analysis up to a depth of $\sim 1 \mu \mathrm{m}$. Some of the $\mathrm{Cu}$ reading might have been a systems peak from the brass stage).

The next goal was to check if $\mathrm{Cd}$ accumulated near the edges. For this, an area was chosen along the left rim of the cathode (which gradually receded from view) only $2 \mathrm{~mm}$ below the upper right corner (FIG. 73). 
FIG. 73: Micrograph of left edge of the $\mathrm{H}$ cell cathode after electrolysis, with the tip that was lower in the electrolyte above the picture. This was the spotweld side, facing the anode.

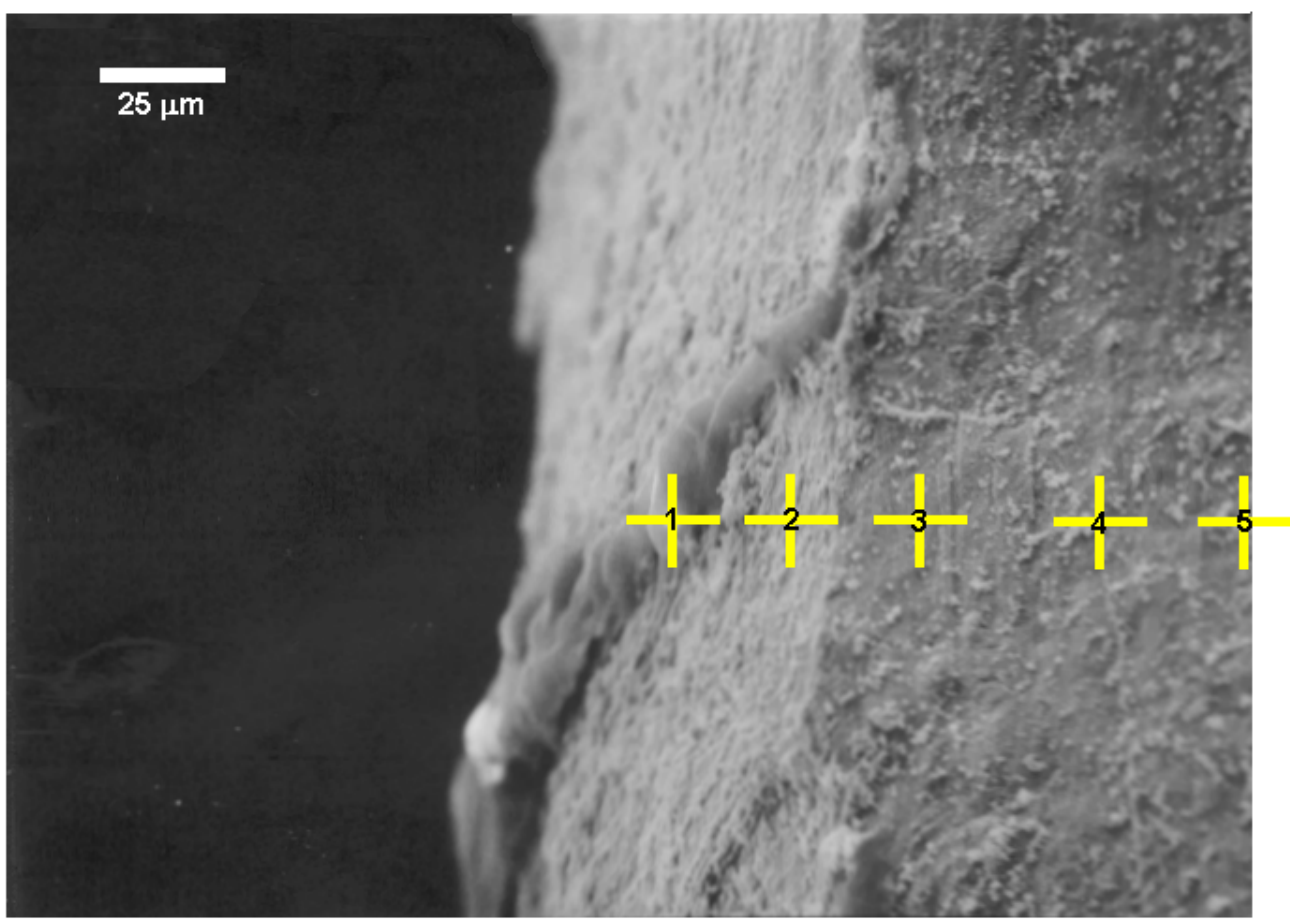

It shows the five spots from which X-ray spectra were acquired.

X-rays were acquired from a first spot on the rim, spot 1 in FIG. 73, on a little ridge-like formation. There were almost 4 atoms of $\mathrm{Cd}$ for every $10 \mathrm{of} \mathrm{Pd}$ : the number concentration of $\mathrm{Cd}$ was $39.80 \pm 1.84 \%$ relative to $\mathrm{Pd}$. The local number concentration of $\mathrm{Pd}$ was $18.34 \pm 0.38 \%$; the local number concentration of $\mathrm{Cd}$ was $7.30 \pm 0.33 \%$, including only the metallic elements in the analysis. The spectrum from this spot 1 is shown in FIG. 74 and the results of the Quantitative Analysis are shown in Table 51. Table 52 lists the results for the metallic elements only: 
FIG. 74: X-ray spectrum from spot 1 in FIG. 73

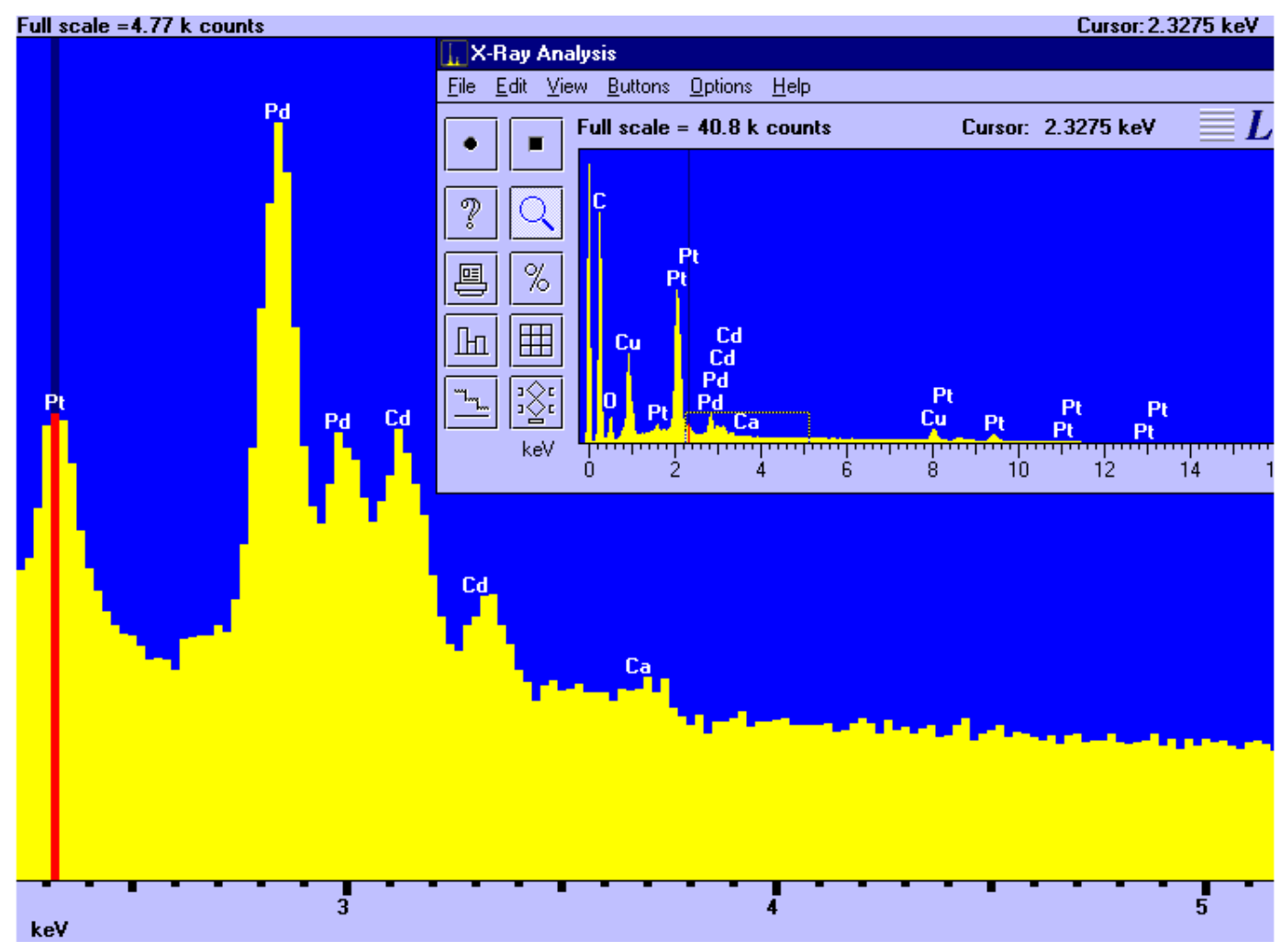

Table 51: Results of elemental analysis of spectrum of FIG. 74, from spot 1 in FIG. 73.

\begin{tabular}{lrrr}
\multicolumn{5}{c}{$\begin{array}{l}\text { In number } \\
\text { of atoms }\end{array}$} & \multicolumn{2}{l}{ In mass } & \multicolumn{1}{l}{ 而 mass } \\
$\mathrm{C}$ & $81.60 \%$ & $53.33 \%$ & $0.17 \%$ \\
$\mathrm{O}$ & $13.67 \%$ & $11.90 \%$ & $0.16 \%$ \\
$\mathrm{~S}$ & $0.15 \%$ & $0.26 \%$ & $0.03 \%$ \\
$\mathrm{Cu}$ & $1.30 \%$ & $4.49 \%$ & $0.09 \%$ \\
$\mathrm{Pd}$ & $0.72 \%$ & $4.18 \%$ & $0.09 \%$ \\
$\mathrm{Ag}$ & $0.02 \%$ & $0.12 \%$ & $0.11 \%$ \\
$\mathrm{Cd}$ & $0.29 \%$ & $1.80 \%$ & $0.09 \%$ \\
$\mathrm{Pt}$ & $2.25 \%$ & $23.92 \%$ & $0.11 \%$
\end{tabular}

(Surface analysis up to a depth of $\sim 1 \mu \mathrm{m}$. Some of the $\mathrm{Cu}$ reading might have been a systems peak from the brass stage). 
Table 52: Results of analysis of spectrum of FIG. 74, from spot 1 in FIG. 73, for the metallic elements. An actual separate SEMQuant analysis was conducted for these elements only.

\begin{tabular}{lrrr}
\multicolumn{5}{c}{ In number } & & \\
& of atoms & In mass & \multicolumn{1}{c}{ O in mass } \\
$\mathrm{Cu}$ & $24.26 \%$ & $10.98 \%$ & $0.22 \%$ \\
$\mathrm{Pd}$ & $18.34 \%$ & $13.90 \%$ & $0.29 \%$ \\
$\mathrm{Ag}$ & $0.52 \%$ & $0.40 \%$ & $0.35 \%$ \\
$\mathrm{Cd}$ & $7.30 \%$ & $5.84 \%$ & $0.27 \%$ \\
$\mathrm{Pt}$ & $49.59 \%$ & $68.88 \%$ & $0.43 \%$
\end{tabular}

(Surface analysis up to a depth of $\sim 1 \mu \mathrm{m}$. Some of the $\mathrm{Cu}$ reading might have been a systems peak from the brass stage).

Then the spot was moved to the right, almost to the line where the face of the cathode and the rim met: spot 2 .

On that location, the number concentration of cadmium had risen to $9.38 \pm 0.51 \%$, with the local number concentration of Pd being $32.15 \pm 0.59 \%$. Relative to Pd, therefore, the number abundance of $\mathrm{Cd}$ had decreased somewhat: there were now only 29 atoms of Cd for every 100 of Pd.

The spectrum from spot 2 is shown in FIG. 75; and the results of the quantitative analysis of this spectrum are shown in Tables 53 (for all the elements) and 54 (for the metallic elements only): 
FIG. 75: X-ray spectrum from spot 2 in FIG. 73

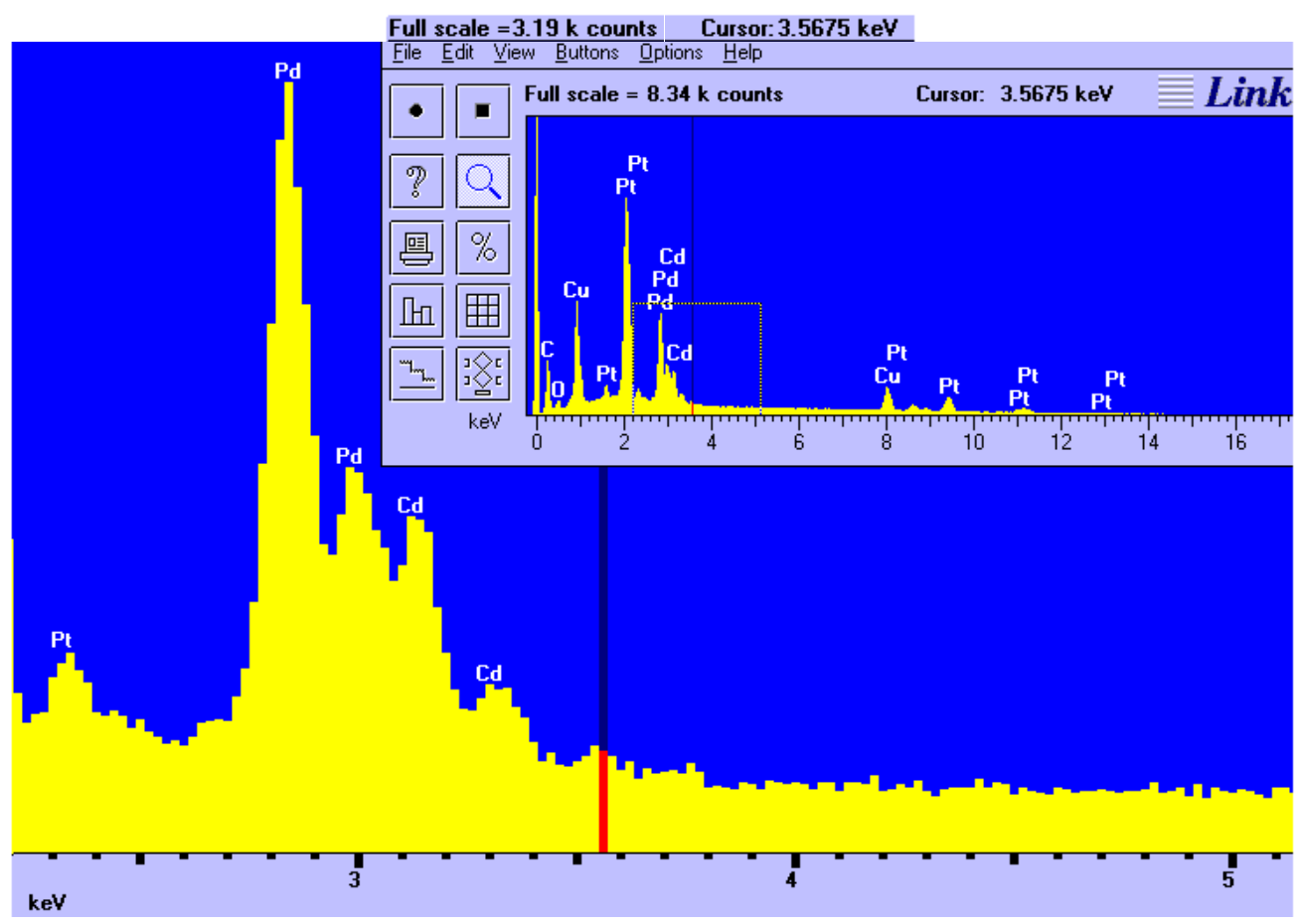

Table 53: Results of analysis of spectrum of FIG. 75, from spot 2 in FIG. 73:

\begin{tabular}{lrrr}
\multicolumn{5}{c}{$\begin{array}{l}\text { In number } \\
\text { of atoms }\end{array}$} & In mass & \multicolumn{2}{c}{$\sigma_{\text {in }}$ mass } \\
C & $64.50 \%$ & $18.42 \%$ & $0.29 \%$ \\
$\mathrm{O}$ & $9.49 \%$ & $3.61 \%$ & $0.34 \%$ \\
$\mathrm{~S}$ & $0.30 \%$ & $0.23 \%$ & $0.10 \%$ \\
$\mathrm{Cu}$ & $6.26 \%$ & $9.46 \%$ & $0.29 \%$ \\
$\mathrm{Pd}$ & $8.07 \%$ & $20.42 \%$ & $0.39 \%$ \\
$\mathrm{Ag}$ & $0.15 \%$ & $0.38 \%$ & $0.47 \%$ \\
$\mathrm{Cd}$ & $2.36 \%$ & $6.32 \%$ & $0.35 \%$ \\
$\mathrm{Pt}$ & $8.87 \%$ & $41.16 \%$ & $0.44 \%$
\end{tabular}

(Surface analysis up to a depth of $\sim 1 \mu \mathrm{m}$. Some of the $\mathrm{Cu}$ reading might have been a systems peak from the brass stage). 
Table 54: Results of analysis of spectrum of FIG. 75, from spot 2 in FIG. 73, for the metallic elements. An actual separate SEMQuant Analysis was conducted for these elements only

\begin{tabular}{|c|c|c|c|}
\hline & $\begin{array}{l}\text { In number } \\
\text { of atoms }\end{array}$ & In mass & $\sigma_{\text {in }}$ mass \\
\hline $\mathrm{Cu}$ & $23.38 \%$ & $11.65 \%$ & $0.35 \%$ \\
\hline $\mathrm{Pd}$ & $32.15 \%$ & $26.82 \%$ & $0.49 \%$ \\
\hline $\mathrm{Ag}$ & $0.59 \%$ & $0.50 \%$ & $0.61 \%$ \\
\hline $\mathrm{Cd}$ & $9.38 \%$ & $8.27 \%$ & $0.45 \%$ \\
\hline $\mathrm{Pt}$ & $34.50 \%$ & $52.76 \%$ & $0.59 \%$ \\
\hline
\end{tabular}

(Surface analysis up to a depth of $\sim 1 \mu \mathrm{m}$. Some of the $\mathrm{Cu}$ reading might have been a systems peak from the brass stage).

On spot 3 farther to the right, already on the flat face of the cathode, the number abundance of cadmium was $7.44 \pm 0.54 \%$, and the local number abundance of $\mathrm{Pd}$ was $49.21 \pm 0.69 \%$.

The spectrum is shown in FIG. 76, the results of the SEMQuant analysis are listed in Tables 55 (for all the elements) and 56 (for the metallic elements only). 
FIG. 76: X-ray spectrum from spot 3 in FIG. 73

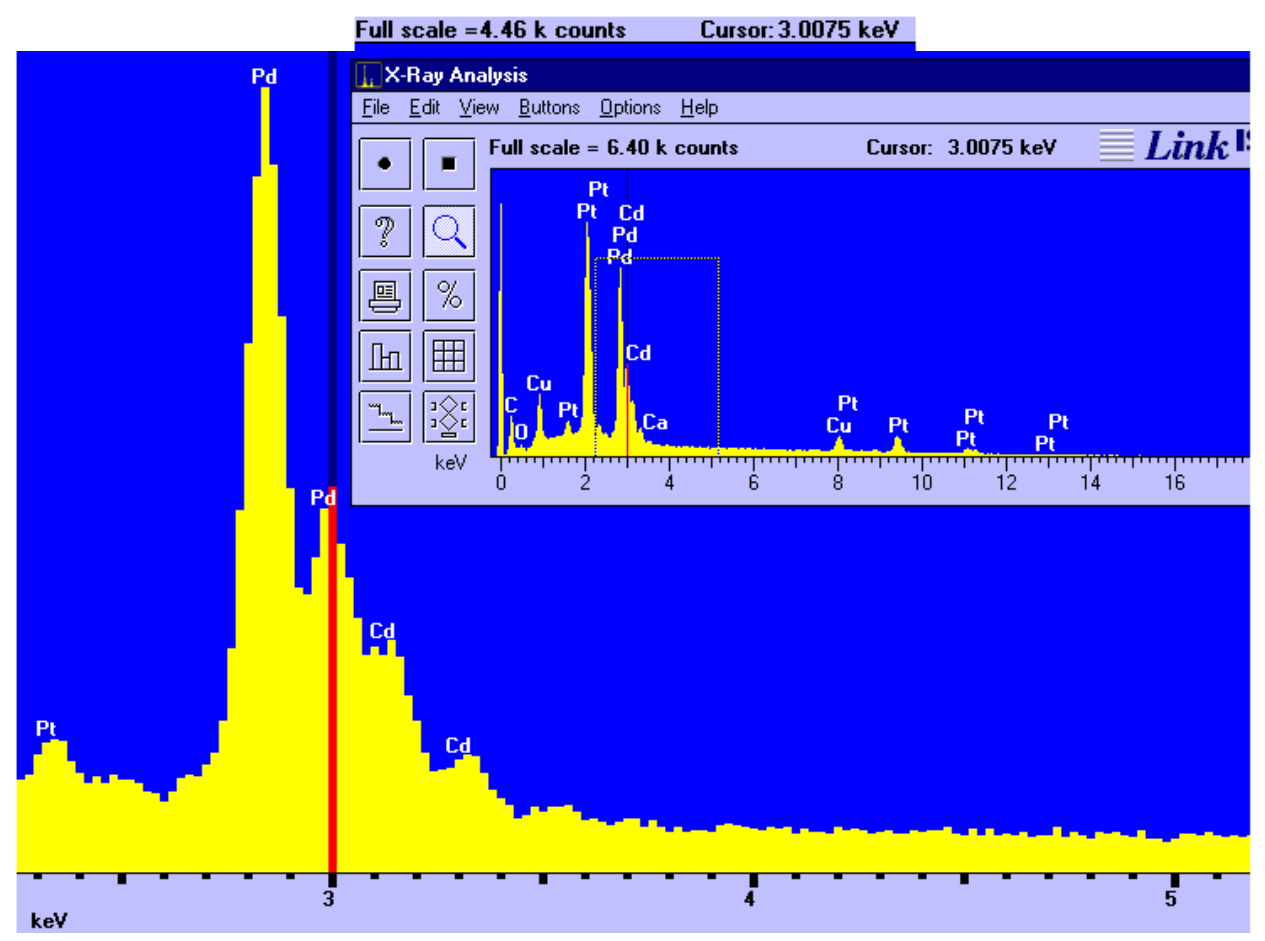

Table 55: Results of elemental analysis of spectrum of FIG. 76, from spot 3 in FIG. 73

\begin{tabular}{lrrr}
\multicolumn{5}{c}{$\begin{array}{l}\text { In number } \\
\text { of atoms }\end{array}$} & In mass & \multicolumn{2}{c}{ O in mass } \\
& $53.08 \%$ & $10.78 \%$ & $0.24 \%$ \\
$\mathrm{C}$ & $6.16 \%$ & $1.67 \%$ & $0.34 \%$ \\
$\mathrm{O}$ & $0.69 \%$ & $0.37 \%$ & $0.10 \%$ \\
$\mathrm{~S}$ & $5.04 \%$ & $5.41 \%$ & $0.28 \%$ \\
$\mathrm{Cu}$ & $19.72 \%$ & $35.48 \%$ & $0.50 \%$ \\
$\mathrm{Pd}$ & $0.02 \%$ & $0.03 \%$ & $0.59 \%$ \\
$\mathrm{Ag}$ & $2.98 \%$ & $5.66 \%$ & $0.41 \%$ \\
$\mathrm{Cd}$ & $12.31 \%$ & $40.60 \%$ & $0.49 \%$ \\
$\mathrm{Pt}$ & & &
\end{tabular}

(Surface analysis up to a depth of $\sim 1 \mu \mathrm{m}$. Some of the $\mathrm{Cu}$ reading might have been a systems peak from the brass stage). 
Table 56: Results of analysis of spectrum of FIG. 76, from spot 3 in FIG. 73, for the metallic elements

\begin{tabular}{lrrr}
\multicolumn{5}{c}{ In number } & & \\
& of atoms & In mass & \multicolumn{1}{c}{ O in mass } \\
$\mathrm{Cu}$ & $12.58 \%$ & $6.21 \%$ & $0.32 \%$ \\
$\mathrm{Pd}$ & $49.21 \%$ & $40.70 \%$ & $0.57 \%$ \\
$\mathrm{Ag}$ & $0.05 \%$ & $0.03 \%$ & $0.68 \%$ \\
$\mathrm{Cd}$ & $7.44 \%$ & $6.49 \%$ & $0.47 \%$ \\
$\mathrm{Pt}$ & $30.72 \%$ & $46.57 \%$ & $0.56 \%$
\end{tabular}

(Surface analysis up to a depth of $\sim 1 \mu \mathrm{m}$. Some of the $\mathrm{Cu}$ reading might have been a systems peak from the brass stage).

Slightly even farther to the right, on spot 4 , the number concentration of cadmium was $7.96 \pm 0.55 \%$, with the local number concentration of Pd being $46.64 \pm 0.70 \%$.

The spectrum from spot 4 is displayed in FIG. 77; the results of the SEMQuant quantitative analysis are listed in Tables 57 (for all the elements) and 58 (for the metallic elements only): 
FIG. 77: X-ray spectrum from spot 4 in FIG. 73

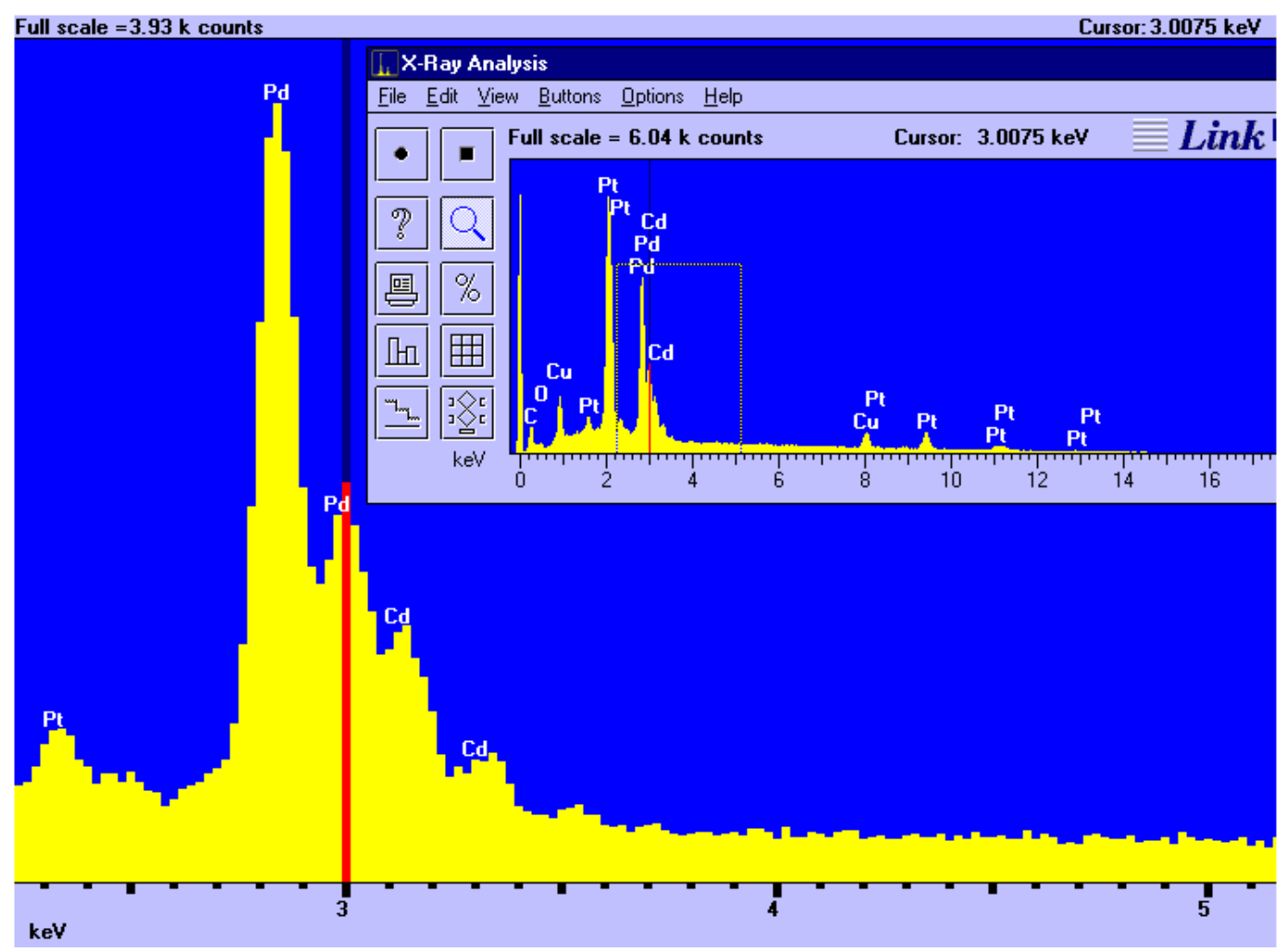

Table 57: Results of elemental analysis of spectrum of FIG. 77, from spot 4 in FIG. 73

\begin{tabular}{|c|c|c|c|}
\hline & $\begin{array}{l}\text { In number } \\
\text { of atoms }\end{array}$ & In mass & $\sigma_{\text {in }}$ mass \\
\hline C & $44.50 \%$ & $7.35 \%$ & $6 \quad 0.21 \%$ \\
\hline $\mathrm{O}$ & $3.69 \%$ & $0.81 \%$ & $0.32 \%$ \\
\hline$S$ & $0.81 \%$ & $0.36 \%$ & $0.11 \%$ \\
\hline $\mathrm{Cu}$ & $6.25 \%$ & $5.46 \%$ & $0.28 \%$ \\
\hline $\mathrm{Pd}$ & $23.78 \%$ & $34.78 \%$ & $0.52 \%$ \\
\hline $\mathrm{Ag}$ & $0.29 \%$ & $0.43 \%$ & $0.62 \%$ \\
\hline $\mathrm{Cd}$ & $4.06 \%$ & $6.27 \%$ & $0.44 \%$ \\
\hline $\mathrm{Pt}$ & $16.61 \%$ & $44.55 \%$ & $0.54 \%$ \\
\hline
\end{tabular}

(Surface analysis up to a depth of $\sim 1 \mu \mathrm{m}$. Some of the $\mathrm{Cu}$ reading might have been a systems peak from the brass stage). 
Table 58: Results of analysis of spectrum of FIG. 77, from spot 4 in FIG. 73, for the metallic elements:

\begin{tabular}{lrrr}
\multicolumn{5}{c}{ In number } & & \\
& of atoms & In mass & \multicolumn{1}{c}{ O in mass } \\
$\mathrm{Cu}$ & $12.26 \%$ & $5.97 \%$ & $0.31 \%$ \\
$\mathrm{Pd}$ & $46.64 \%$ & $38.02 \%$ & $0.57 \%$ \\
$\mathrm{Ag}$ & $0.57 \%$ & $0.47 \%$ & $0.68 \%$ \\
$\mathrm{Cd}$ & $7.96 \%$ & $6.85 \%$ & $0.48 \%$ \\
$\mathrm{Pt}$ & $32.58 \%$ & $48.69 \%$ & $0.59 \%$
\end{tabular}

(Surface analysis up to a depth of $\sim 1 \mu \mathrm{m}$. Some of the $\mathrm{Cu}$ reading might have been a systems peak from the brass stage).

A last spot at the very right edge of the field of view, spot 5, gave a number concentration of $5.25 \pm 0.52 \%$ for $\mathrm{Cd}$ and $54.57 \pm 0.71 \%$ for $\mathrm{Pd}$.

The X-ray spectrum from this spot 5 is displayed in FIG. 78; the elemental composition resulting from this spectrum is listed in Tables 59 (for all the elements) and 60 (for the metallic elements only): 
FIG. 78: X-ray spectrum from spot 5 in FIG. 73

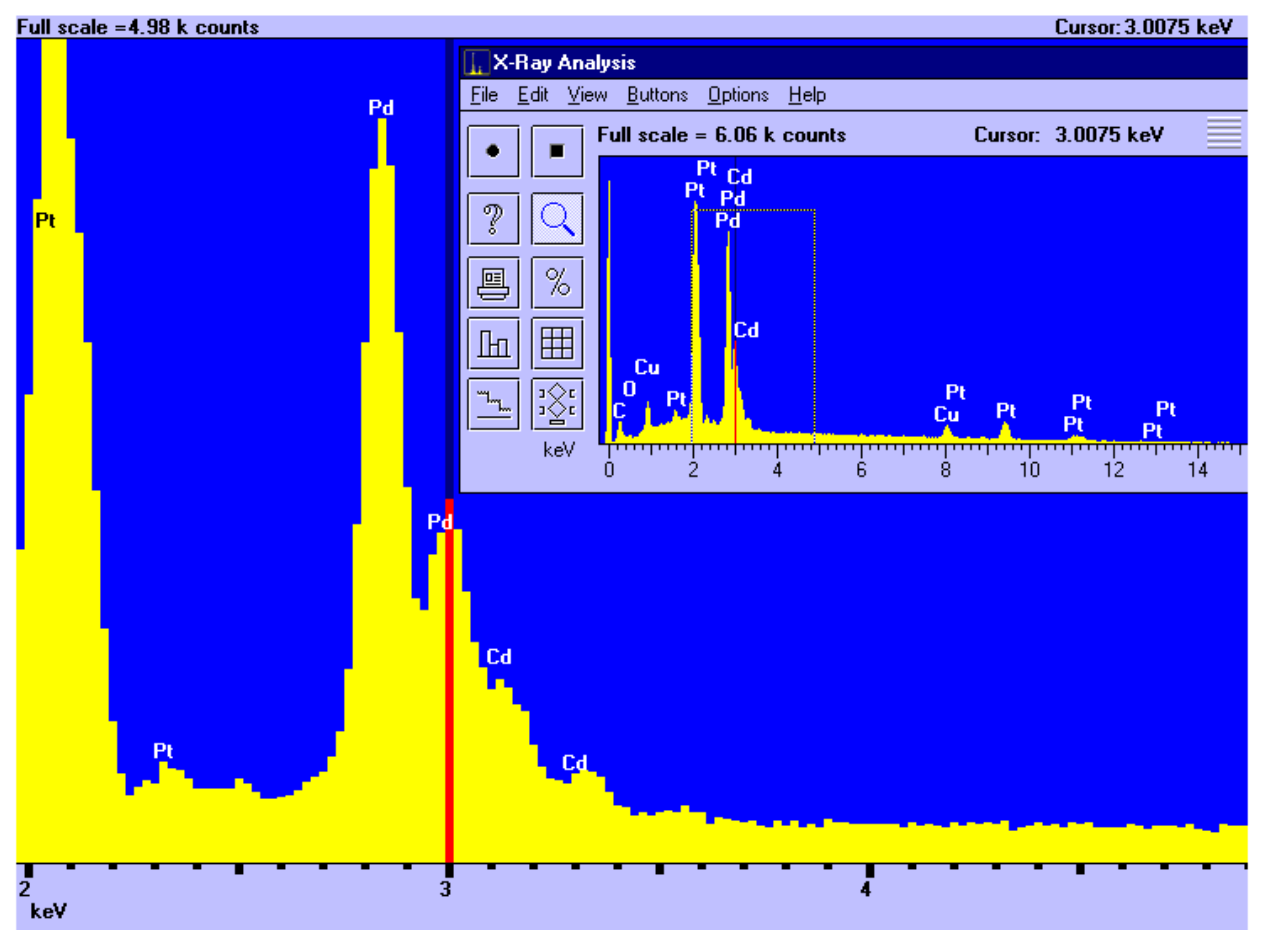

Table 59: Results of elemental analysis of spectrum of FIG. 78, from spot 5 in FIG. 73.

\begin{tabular}{lrrr}
\multicolumn{5}{c}{$\begin{array}{l}\text { In number } \\
\text { of atoms }\end{array}$} & In mass & \multicolumn{2}{c}{$\sigma_{\text {in }}$ mass } \\
C & $40.15 \%$ & $6.10 \%$ & $0.19 \%$ \\
$\mathrm{O}$ & $2.75 \%$ & $0.56 \%$ & $0.30 \%$ \\
$\mathrm{~S}$ & $0.25 \%$ & $0.10 \%$ & $0.11 \%$ \\
$\mathrm{Cu}$ & $5.49 \%$ & $4.41 \%$ & $0.28 \%$ \\
$\mathrm{Pd}$ & $31.03 \%$ & $41.76 \%$ & $0.54 \%$ \\
$\mathrm{Ag}$ & $0.00 \%$ & $0.00 \%$ & $0.63 \%$ \\
$\mathrm{Cd}$ & $2.99 \%$ & $4.25 \%$ & $0.42 \%$ \\
$\mathrm{Pt}$ & $17.35 \%$ & $42.81 \%$ & $0.52 \%$
\end{tabular}

(Surface analysis up to a depth of $\sim 1 \mu \mathrm{m}$. Some of the $\mathrm{Cu}$ reading might have been a systems peak from the brass stage). 
Table 60: Results of analysis of spectrum of FIG. 78, from spot 5 in FIG. 73, for the metallic elements

\begin{tabular}{lrrr}
\multicolumn{5}{c}{ In number } \\
of atoms & In mass & \multicolumn{2}{c}{ 而 } \\
& $9.66 \%$ & $4.73 \%$ & $0.30 \%$ \\
$\mathrm{Cu}$ & $54.57 \%$ & $44.79 \%$ & $0.58 \%$ \\
$\mathrm{Pd}$ & $0.00 \%$ & $0.00 \%$ & $0.67 \%$ \\
$\mathrm{Ag}$ & $5.25 \%$ & $4.56 \%$ & $0.45 \%$ \\
$\mathrm{Cd}$ & $30.52 \%$ & $45.91 \%$ & $0.56 \%$ \\
$\mathrm{Pt}$ & & &
\end{tabular}

(Surface analysis up to a depth of $\sim 1 \mu \mathrm{m}$. Some of the $\mathrm{Cu}$ reading might have been a systems peak from the brass stage).

It is noteworthy that the number abundance of carbon seemed to diminish with the distance from the edge of the cathode. FIG. 79 contrasts the number abundances of $\mathrm{C}$ that were found at the five different spots from which $\mathrm{X}$-rays were acquired.

FIG. 79: Comparison of the $C$ number abundance at the five different spots from which $X-$ rays were acquired:

C number abundance

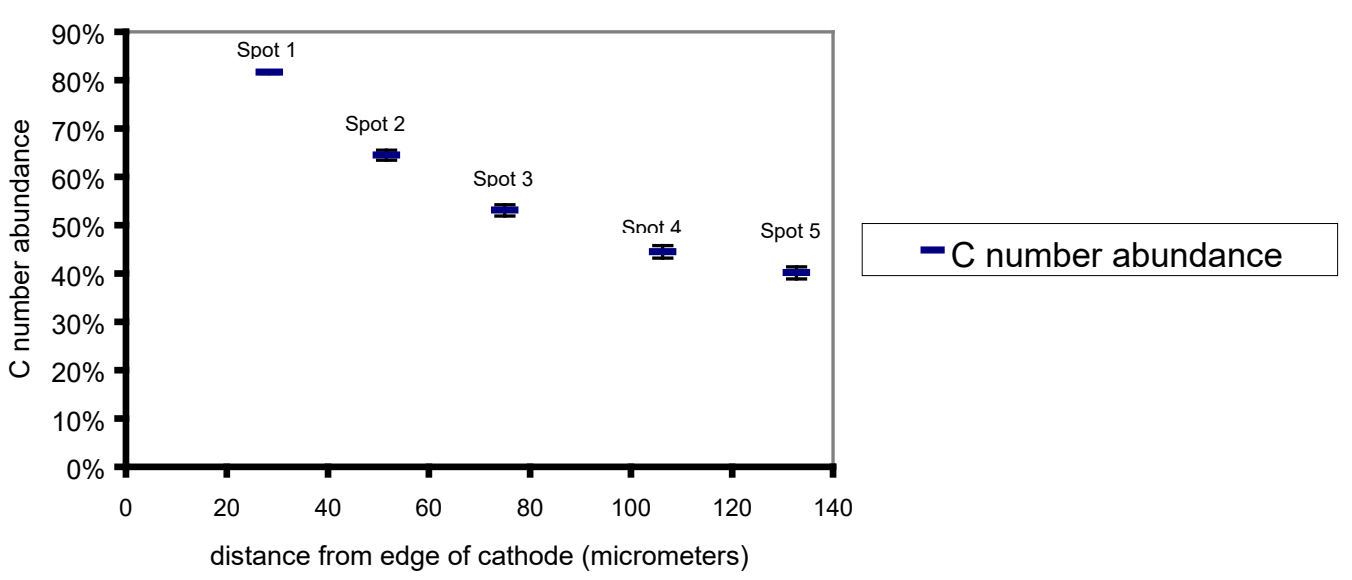




\section{APPENDIX H: ADDITIONAL MICROGRAPHS AND SPECTRA FROM THE D CELL CATHODE OF THE SECOND EXPERIMENT AFTER ELECTROLYSIS.}

FIGS. 80 and 81 contrast the appearance before and after the electrolysis of the spotweld side of D cell cathode (which faced the anode during electrolysis).

The curvature of the cathode after electrolysis is not as visible in FIG. 81 as it was with the other side of the cathode (FIG. 13) due to the fuzziness of FIG. 81 and the fact that FIG. 81 shows the cathode almost face-on.

FIG. 80: D cell cathode of the second experiment before electrolysis, spotweld side (facing the anode).

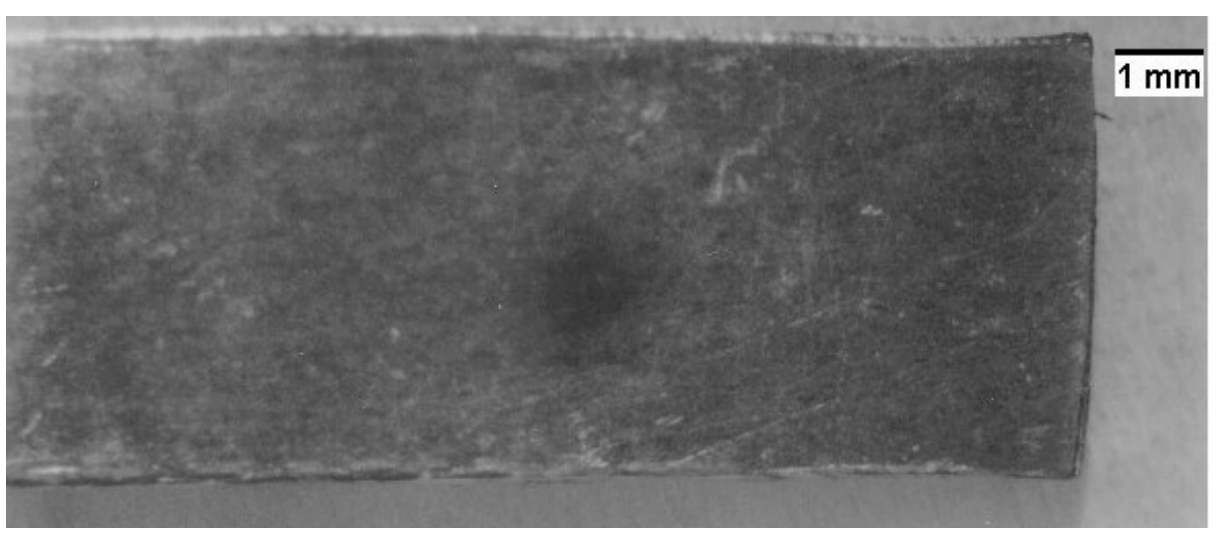


FIG. 81: D cell cathode of the second experiment after electrolysis, spotweld side (facing the anode).

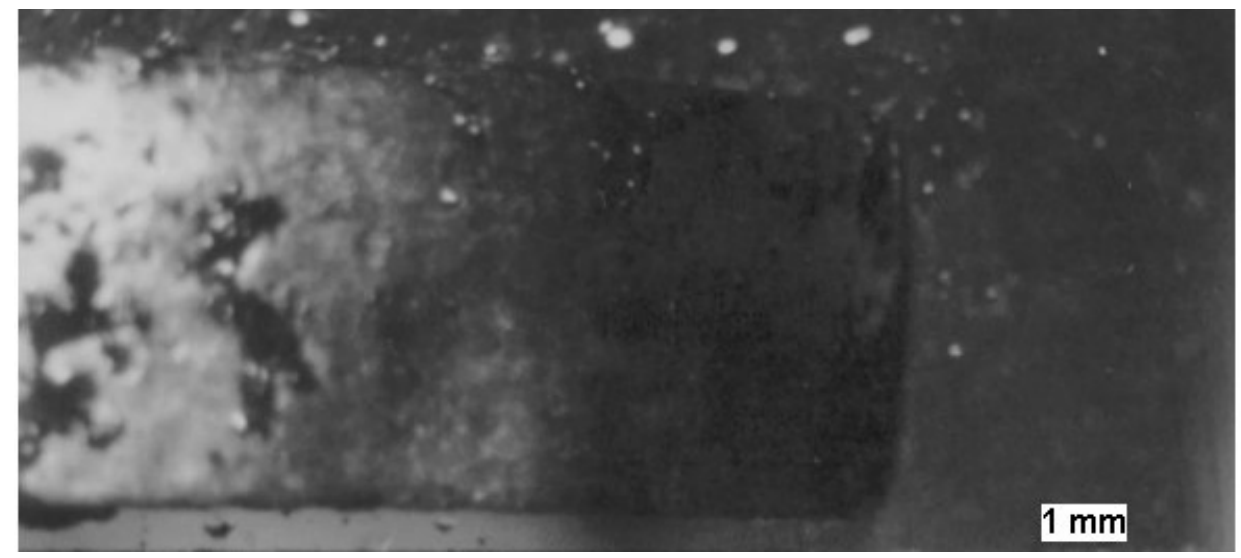

FIG. 82 gives an edge-on view of the D cell of the second experiment after electrolysis, showing more clearly the curvature.

FIG. 82: Edge-on photo of D cell cathode bent after electrolysis.

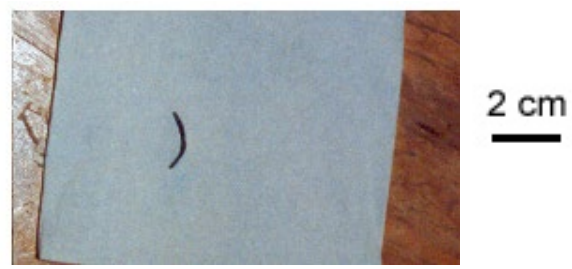

On this cathode, silver was present in the deposit of substance. In regions that were not covered in the substance the concentration of silver was somewhat smaller but still statistically significant. Also, the number concentrations of oxygen and sulfur 
were lower than in the regions with the substance. This suggested that $\mathrm{PdS}$ and $\mathrm{PdO}$ were components of the substance.

A region was chosen on the concave side of the D cell cathode after electrolysis, where the substance and non-substance covered regions met, $1.75 \mathrm{~mm}$ from the right edge and $2.6 \mathrm{~mm}$ from the lower tip. (This side of the cathode was opposite the spotweld and looking away from the anode when the experiment ended). The region is shown in FIG. 83.

FIG. 83: Micrograph of region on the concave side of the D cell cathode after electrolysis, where the substance and non-substance-covered regions met. This side was opposite the spotweld and looking away from the anode.

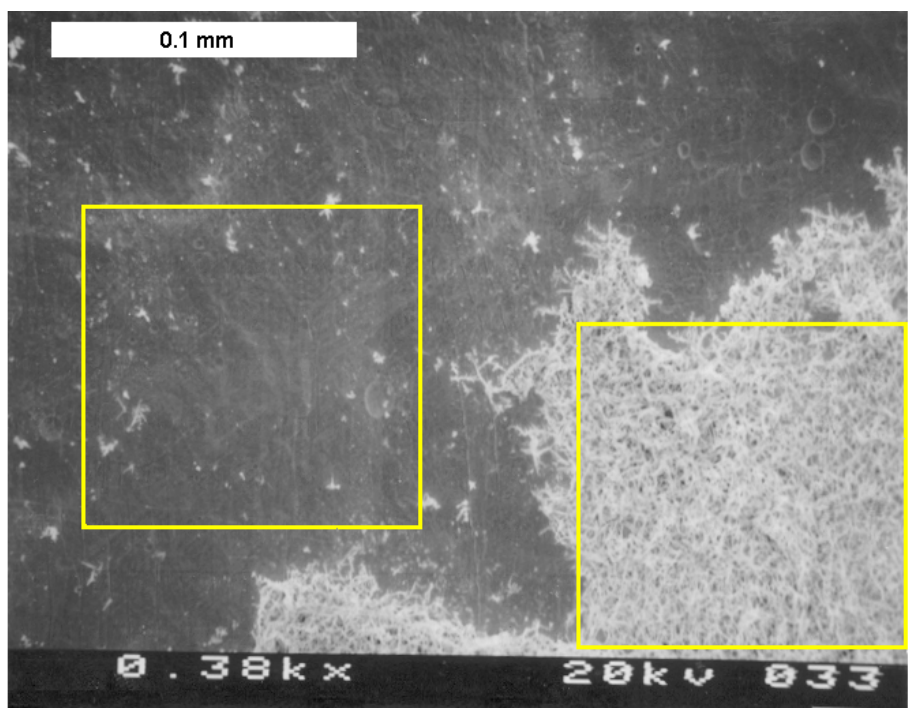


Two selected areas of $0.1 \mathrm{~mm} \times 0.1 \mathrm{~mm}$ were chosen for X-ray acquisition, one on the substance-covered region (right in the image) and another on the nonsubstance-covered region (left in image).

The spectrum from the selected area on the left, on the relatively substance-clear region, is shown in FIG. 84.

Table 61 lists the results of the SEMQuant analysis of this spectrum for all the relevant elements while Table 62 lists the results for the metallic elements only.

FIG. 84: X-ray spectrum from left selected area in FIG. 83, on the substance-clear region.

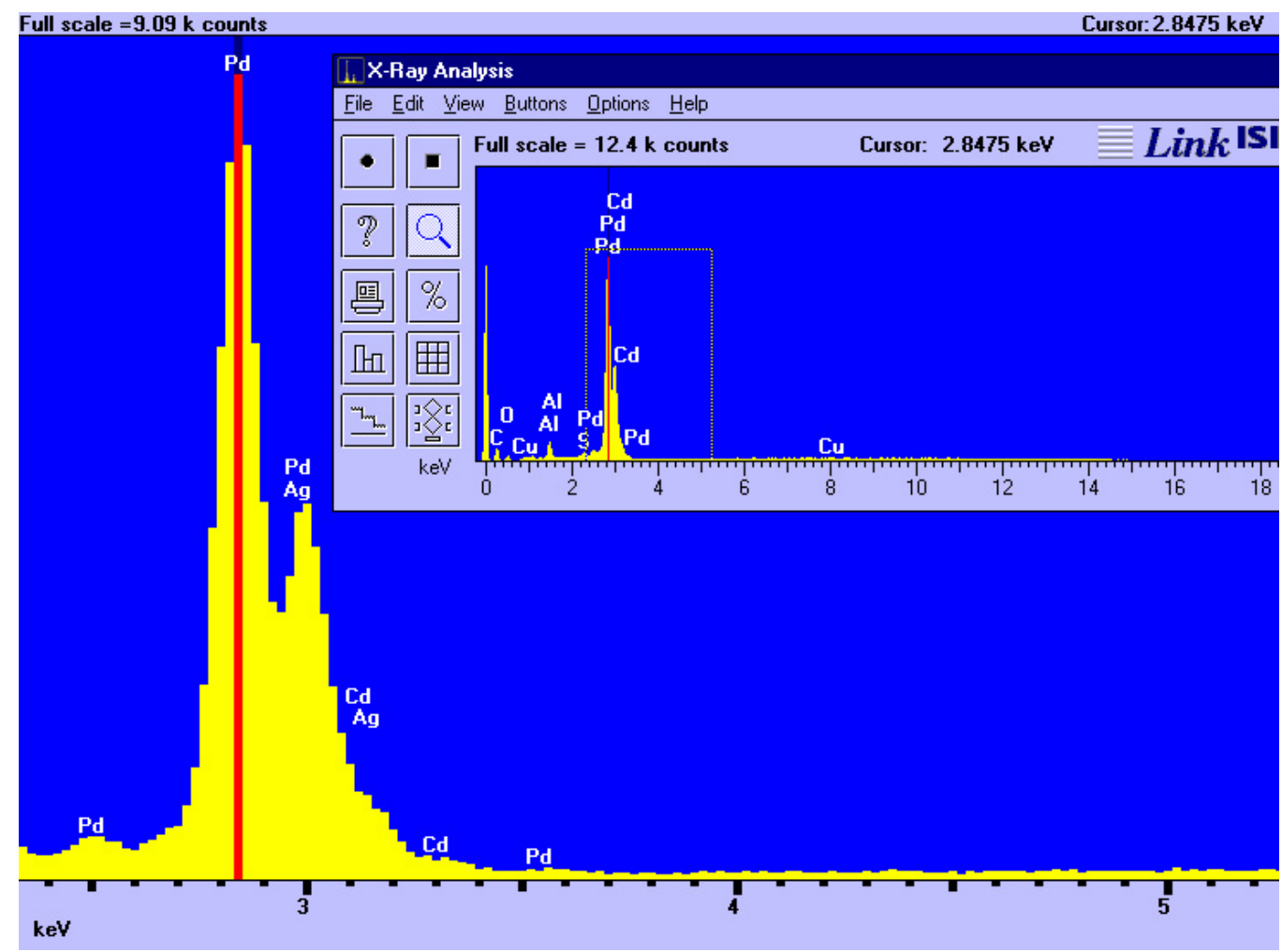


Table 61: Results of elemental analysis of spectrum of FIG. 84, from left selected area in FIG. 83.

\begin{tabular}{lrrr}
\multicolumn{5}{c}{$\begin{array}{l}\text { In number } \\
\text { of atoms }\end{array}$} & In mass & \multicolumn{2}{l}{ 位 } \\
& $24.75 \%$ & $5.16 \%$ & $0.13 \%$ \\
$\mathrm{C}$ & $27.14 \%$ & $7.54 \%$ & $0.42 \%$ \\
$\mathrm{O}$ & $1.13 \%$ & $0.63 \%$ & $0.06 \%$ \\
$\mathrm{~S}$ & $0.25 \%$ & $0.27 \%$ & $0.31 \%$ \\
$\mathrm{Cu}$ & $45.89 \%$ & $84.80 \%$ & $0.88 \%$ \\
$\mathrm{Pd}$ & $0.85 \%$ & $1.59 \%$ & $0.72 \%$ \\
$\mathrm{Ag}$ & $0.00 \%$ & $0.00 \%$ & $0.42 \%$ \\
$\mathrm{Cd}$ & $0.00 \%$ & $0.00 \%$ & $0.17 \%$ \\
$\mathrm{Pt}$ & & &
\end{tabular}

(Surface analysis up to a depth of $\sim 1 \mu \mathrm{m}$ ).

Table 62: Analysis of spectrum of FIG. 84, from left selected area in FIG. 83, for the metallic elements.

\begin{tabular}{lrrr}
\multicolumn{5}{c}{$\begin{array}{l}\text { In number } \\
\text { of atoms }\end{array}$} & In mass & \multicolumn{2}{c}{$\sigma_{\text {in }}$ mass } \\
Cu & $0.53 \%$ & $0.31 \%$ & $0.35 \%$ \\
$\mathrm{Pd}$ & $97.67 \%$ & $97.85 \%$ & $1.02 \%$ \\
$\mathrm{Ag}$ & $1.80 \%$ & $1.84 \%$ & $0.83 \%$ \\
$\mathrm{Cd}$ & $0.00 \%$ & $0.00 \%$ & $0.48 \%$ \\
$\mathrm{Pt}$ & $0.00 \%$ & $0.00 \%$ & $0.19 \%$
\end{tabular}

(Surface analysis up to a depth of $\sim 1 \mu \mathrm{m}$ ).

For comparison, the square selected area immediately to the right of the former one, already in the substance-covered region, had a number abundance of sulfur of $2.66 \%$ sulfur instead of $1.13 \%$. The number abundance of $\mathrm{Ag}$ in mass had dropped from $1.80 \%$ in the substance-clear region to $1.32 \%$ (below $2 \sigma$ ) in the substancecovered region. 
The spectrum of this selected area on the right in FIG. 83, on the substance-covered region, is shown in FIG. 85.

The results of the SEMQuant analysis performed on this spectrum are listed in Tables 63 (for all the relevant elements) and 64 (for the metallic elements only):

FIG. 85: X-ray spectrum from selected area on the right in FIG. 83, on the substance-clear region.

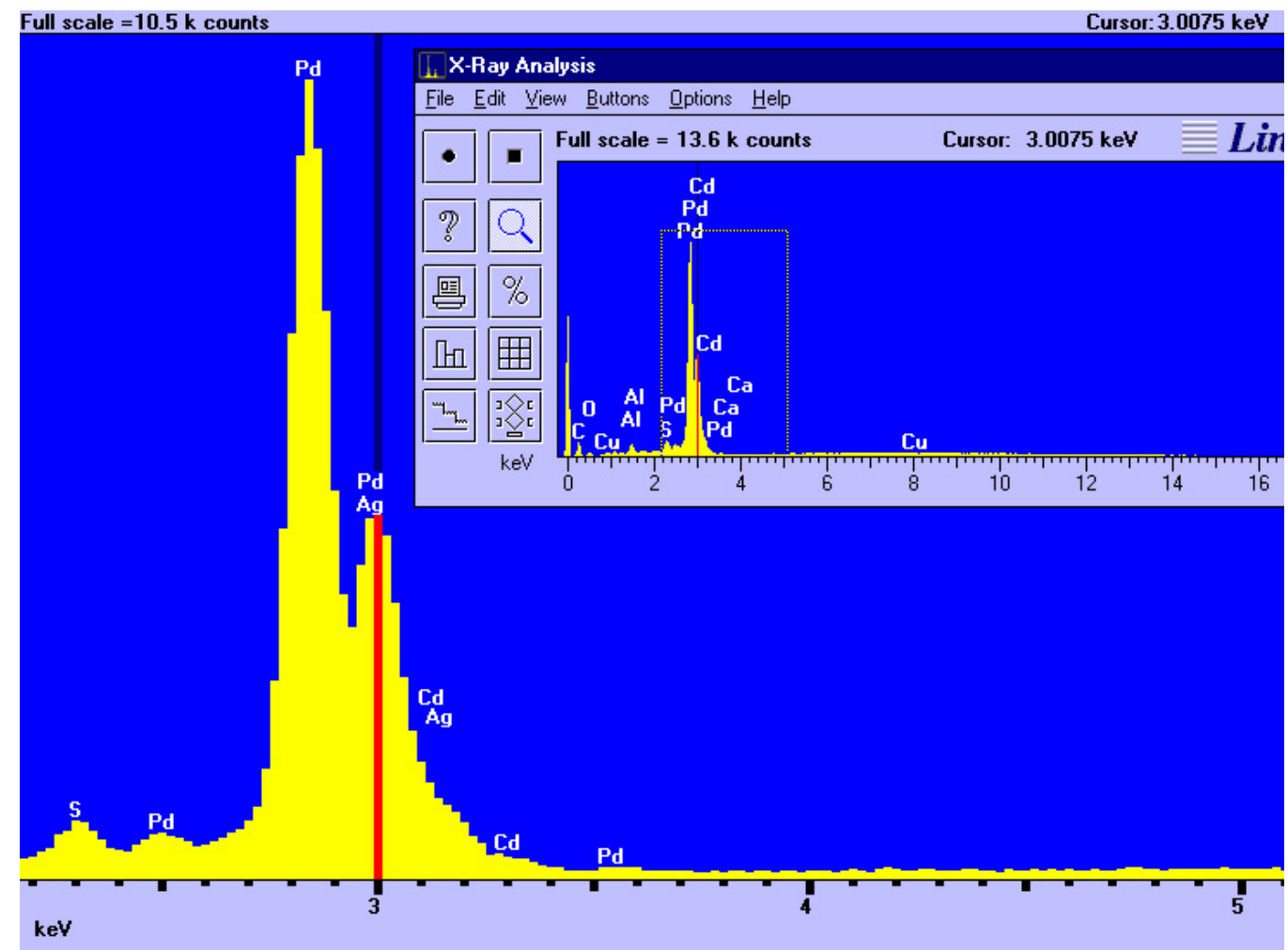


Table 63: Results of elemental analysis of spectrum of FIG. 85, from selected area on the right in FIG. 83.

\begin{tabular}{lrrr}
\multicolumn{5}{c}{$\begin{array}{l}\text { In number } \\
\text { of atoms }\end{array}$} & In mass & \multicolumn{2}{l}{ 而 } \\
& $26.78 \%$ & $5.46 \%$ & $0.13 \%$ \\
$\mathrm{C}$ & $22.55 \%$ & $6.13 \%$ & $0.38 \%$ \\
$\mathrm{O}$ & $2.66 \%$ & $1.45 \%$ & $0.07 \%$ \\
$\mathrm{~S}$ & $0.15 \%$ & $0.16 \%$ & $0.29 \%$ \\
$\mathrm{Cu}$ & $47.03 \%$ & $84.99 \%$ & $0.83 \%$ \\
$\mathrm{Pd}$ & $0.64 \%$ & $1.17 \%$ & $0.68 \%$ \\
$\mathrm{Ag}$ & $0.00 \%$ & $0.00 \%$ & $0.40 \%$ \\
$\mathrm{Cd}$ & $0.20 \%$ & $0.64 \%$ & $0.18 \%$ \\
$\mathrm{Pt}$ & & &
\end{tabular}

(Surface analysis up to a depth of $\sim 1 \mu \mathrm{m}$ ).

Table 64: Results of analysis of spectrum of FIG. 85, from selected area on the right in FIG. 83, for the metallic elements.

\begin{tabular}{lrrr}
\multicolumn{5}{c}{$\begin{array}{l}\text { In number } \\
\text { of atoms }\end{array}$} & In mass & \multicolumn{2}{c}{$\sigma_{\text {in }}$ mass } \\
Cu & $0.31 \%$ & $0.18 \%$ & $0.33 \%$ \\
$\mathrm{Pd}$ & $97.95 \%$ & $97.74 \%$ & $0.95 \%$ \\
$\mathrm{Ag}$ & $1.32 \%$ & $1.34 \%$ & $0.78 \%$ \\
$\mathrm{Cd}$ & $0.00 \%$ & $0.00 \%$ & $0.45 \%$ \\
$\mathrm{Pt}$ & $0.41 \%$ & $0.74 \%$ & $0.20 \%$
\end{tabular}

(Surface analysis up to a depth of $\sim 1 \mu \mathrm{m}$ ).

A $0.4 \mathrm{~mm}$ diameter wide sponge-like structure was situated $1.84 \mathrm{~mm}$ from the right edge of the cathode and $1.3 \mathrm{~mm}$ from the segment along which the cathode had been cut off (the segment being on top in the field of view), on the concave side of the cathode opposite the spotweld, looking away from the anode. FIG. 86 shows the cathode covered with the black spongy substance (which actually looks lighter in the micrographs). The sponge-like formation is visible on the upper right, and it is zoomed out later in FIG. 88. 
FIG. 86: D cell cathode after electrolysis. The curved edge above is the line along which the cathode was detached from the Teflon sheathing after the experiment for examination. This is the concave side of the cathode, opposite the spotweld, looking away from the anode.

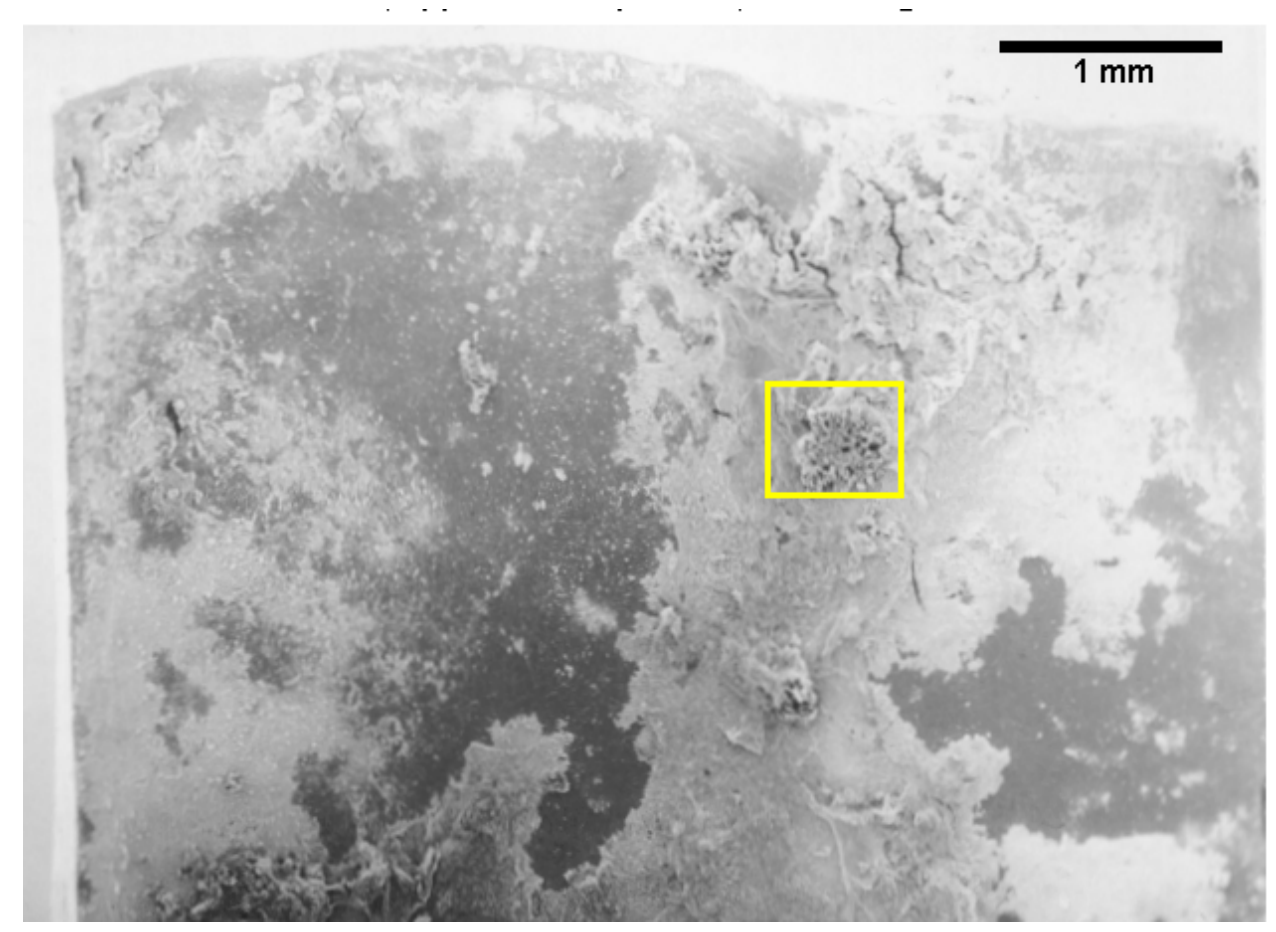

X-rays were acquired from a $2.1 \mathrm{~mm} \times 2.1 \mathrm{~mm}$ general area on this region of the cathode shown in FIG. 86. This general area encompassed both substance and nonsubstance-covered regions, and it was not possible to confirm from its spectrum the presence of silver or cadmium in the few counts that were taken. Still, the spectrum was suggestive of $\mathrm{Cd}$ or $\mathrm{Ag}$ being present and it is shown in FIG. 87. The full results of the analysis are listed in Tables 65 (for all the elements) and 66 (for the metallic elements only): 
FIG. 87: X-ray spectrum from $2.1 \mathrm{~mm} \times 2.1 \mathrm{~mm}$ general area on the region of the $D$ cathode in FIG. 86.

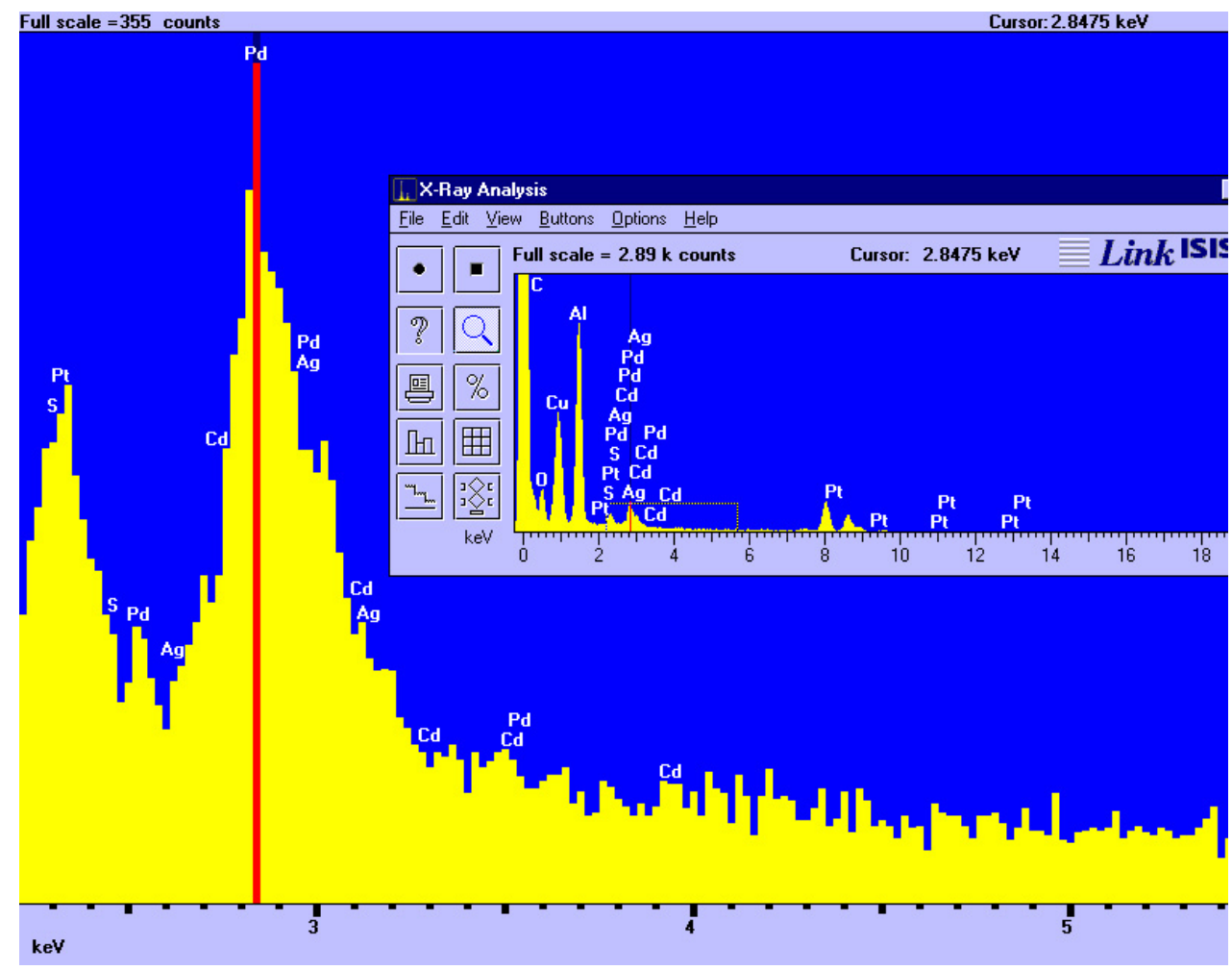

Table 65: Results of elemental analysis of spectrum of FIG. 87.

\begin{tabular}{lrrr}
\multicolumn{5}{c}{$\begin{array}{l}\text { In number } \\
\text { of atoms }\end{array}$} & In mass & \multicolumn{1}{l}{ 位 mass } \\
$\mathrm{C}$ & $96.40 \%$ & $94.95 \%$ & $0.57 \%$ \\
$\mathrm{O}$ & $3.55 \%$ & $4.65 \%$ & $0.35 \%$ \\
$\mathrm{~S}$ & $0.00 \%$ & $0.00 \%$ & $0.05 \%$ \\
$\mathrm{Cu}$ & $0.00 \%$ & $0.00 \%$ & $0.18 \%$ \\
$\mathrm{Pd}$ & $0.00 \%$ & $0.00 \%$ & $0.22 \%$ \\
$\mathrm{Ag}$ & $0.01 \%$ & $0.08 \%$ & $0.25 \%$ \\
$\mathrm{Cd}$ & $0.04 \%$ & $0.32 \%$ & $0.19 \%$ \\
$\mathrm{Pt}$ & $0.00 \%$ & $0.00 \%$ & $0.11 \%$
\end{tabular}

(Surface analysis up to a depth of $\sim 1 \mu \mathrm{m}$. The $\mathrm{C}$ peak swamped all the other results). 
Table 66: Results of analysis of spectrum of FIG. 87, for the metallic elements. An actual separate SEMQuant analysis was conducted for these metallic elements only.

\begin{tabular}{lrrr}
\multicolumn{5}{c}{ In number } \\
of atoms & In mass & \multicolumn{1}{c}{ 佂 mass } \\
$\mathrm{Cu}$ & $64.05 \%$ & $51.55 \%$ & $5.26 \%$ \\
$\mathrm{Pd}$ & $35.95 \%$ & $48.45 \%$ & $4.94 \%$ \\
$\mathrm{Ag}$ & $0.00 \%$ & $0.00 \%$ & $5.28 \%$ \\
$\mathrm{Cd}$ & $0.00 \%$ & $0.00 \%$ & $4.37 \%$ \\
$\mathrm{Pt}$ & $0.00 \%$ & $0.00 \%$ & $2.59 \%$
\end{tabular}

(Surface analysis up to a depth of $\sim 1 \mu \mathrm{m}$. The $\mathrm{Cu}$ signal was probably a systems peak from the brass stage.)

FIG. 88 zooms out the sponge-like formation of FIG. 86 , and shows the $0.2 \mathrm{~mm} \mathrm{x}$ $0.2 \mathrm{~mm}$ selected area on the feature from which X-rays were acquired.

FIG. 88 displays the X-ray spectrum from this selected area while Table 67 lists the results of the quantitative analysis.

Table 68 lists the results of the analysis for the metallic elements: 
FIG. 88: Sponge-like structure on the concave side of the D cell cathode after electrolysis. Visible as a small feature in FIG. 86, it was located high up the cathode near its middle line, close to the edge of the Teflon sheathing. The spotweld was on the other side.

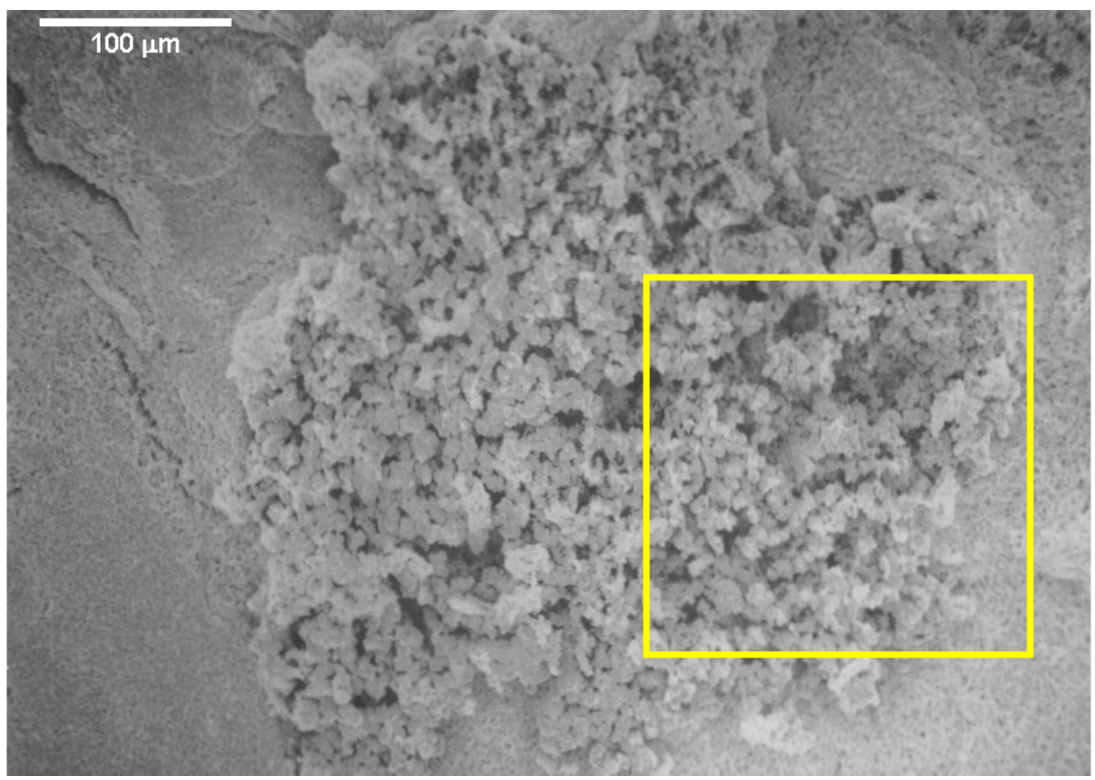

FIG. 89: X-ray spectrum from $0.2 \mathrm{~mm} \times 0.2 \mathrm{~mm}$ selected area in FIG. 88.

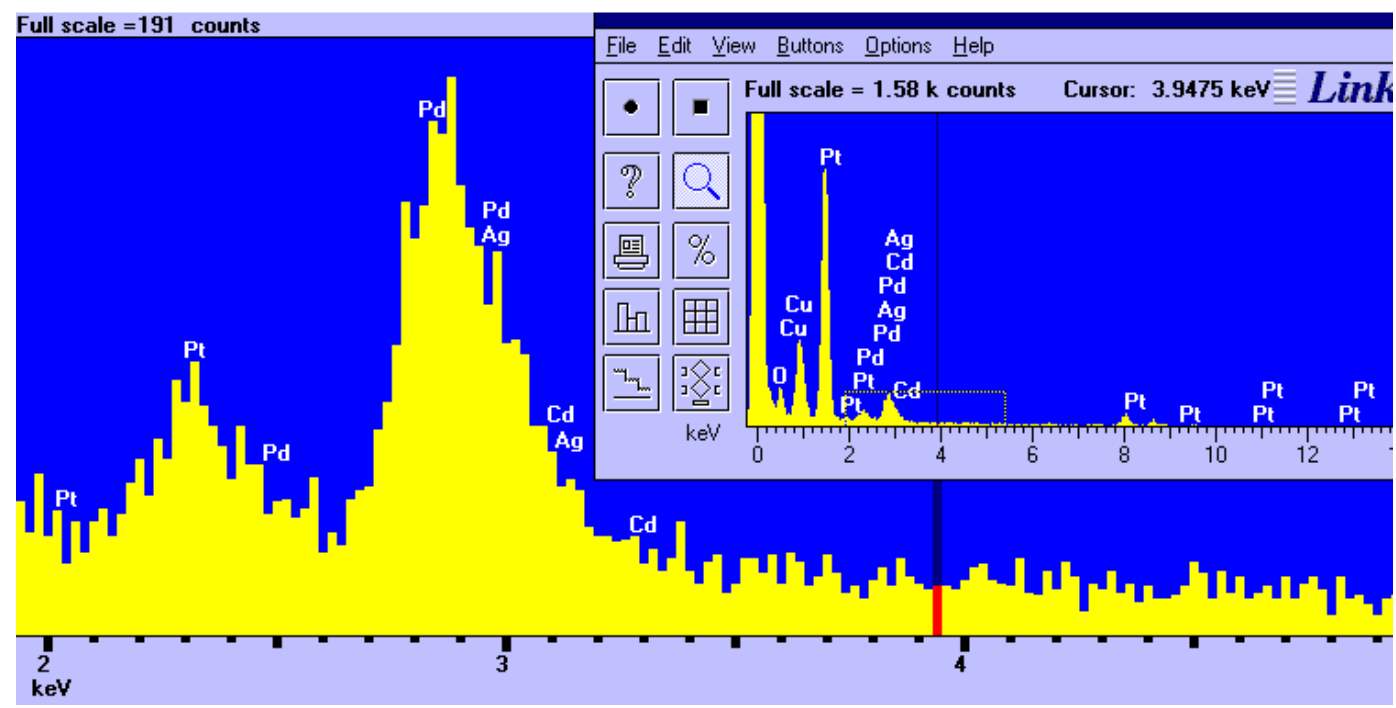


Table 67: Results of elemental analysis of spectrum of FIG. 89, from selected area in FIG.

88.

\begin{tabular}{lrrr}
\multicolumn{5}{c}{$\begin{array}{c}\text { In number } \\
\text { of atoms }\end{array}$} & In mass & \multicolumn{2}{c}{ 而 } \\
& $93.55 \%$ & $91.40 \%$ & $0.57 \%$ \\
$\mathrm{C}$ & $6.44 \%$ & $8.37 \%$ & $0.43 \%$ \\
$\mathrm{O}$ & $0.00 \%$ & $0.00 \%$ & $0.04 \%$ \\
$\mathrm{~S}$ & $0.00 \%$ & $0.00 \%$ & $0.14 \%$ \\
$\mathrm{Cu}$ & $0.00 \%$ & $0.00 \%$ & $0.20 \%$ \\
$\mathrm{Pd}$ & $0.00 \%$ & $0.00 \%$ & $0.22 \%$ \\
$\mathrm{Ag}$ & $0.00 \%$ & $0.04 \%$ & $0.17 \%$ \\
$\mathrm{Cd}$ & $0.01 \%$ & $0.19 \%$ & $0.11 \%$ \\
$\mathrm{Pt}$ & & &
\end{tabular}

(Surface analysis up to a depth of $\sim 1 \mu \mathrm{m}$. The $\mathrm{C}$ peak went off-scale and swamped all the other results).

Table 68: Analysis of spectrum of FIG. 89, from selected area in FIG. 88, for metallic elements. An actual separate SEMQuant analysis was conducted for these elements only.

\begin{tabular}{|c|c|c|c|}
\hline & $\begin{array}{l}\text { In number } \\
\text { of atoms }\end{array}$ & In mass & $\sigma_{\text {in mass }}$ \\
\hline $\mathrm{Cu}$ & $49.71 \%$ & $37.09 \%$ & $6.14 \%$ \\
\hline $\mathrm{Pd}$ & $45.65 \%$ & $57.03 \%$ & $8.14 \%$ \\
\hline $\mathrm{Ag}$ & $4.64 \%$ & $5.88 \%$ & $7.40 \%$ \\
\hline $\mathrm{Cd}$ & $0.00 \%$ & $0.00 \%$ & $6.22 \%$ \\
\hline $\mathrm{Pt}$ & $0.00 \%$ & $0.00 \%$ & $4.65 \%$ \\
\hline
\end{tabular}

(Surface analysis up to a depth of $\sim 1 \mu \mathrm{m}$ ).

FIG. 90 shows a spot at the corner of the segment where the D cell cathode had been detached from the Teflon sheathing for examination after electrolysis. FIG. 91 displays the X-ray spectrum from this spot. SEMQuant analysis revealed that at this spot there was 1 atom of silver for every 6 of palladium. The full results of the analysis are listed in Table 69; Table 70 lists the results for the metallic elements only. 
FIG. 90: Spot at the corner of the edge of the Teflon sheathing of the D cell cathode after electrolysis. The Teflon sheathing is the lighter-gray area above in the small picture on the left; the undulating divide marks the edge of the Teflon sheathing along which the cathode was detached for examination. The region with the spot is zoomed out in the right picture. This was the concave side of the D cell cathode, opposite the spotweld, looking away from the anode.

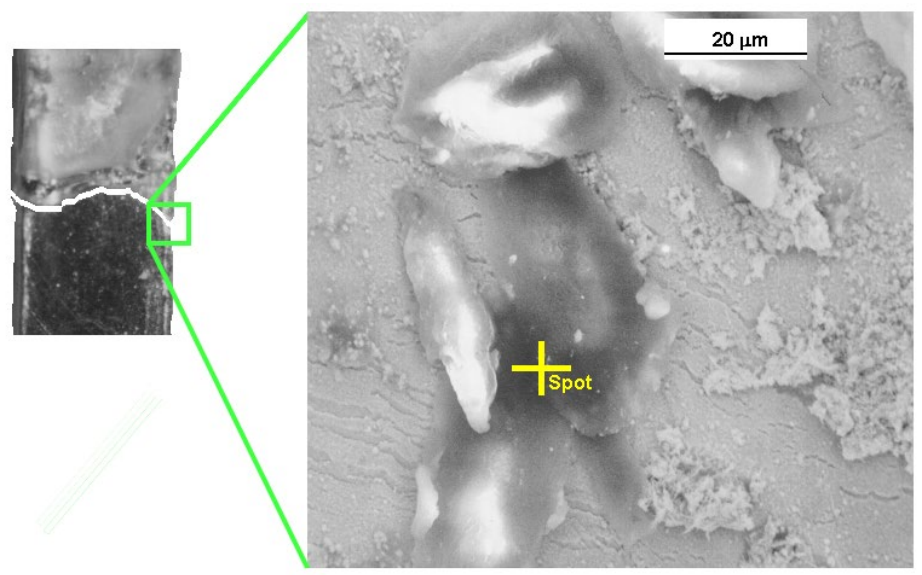

FIG. 91: Spectrum from spot in FIG. 90

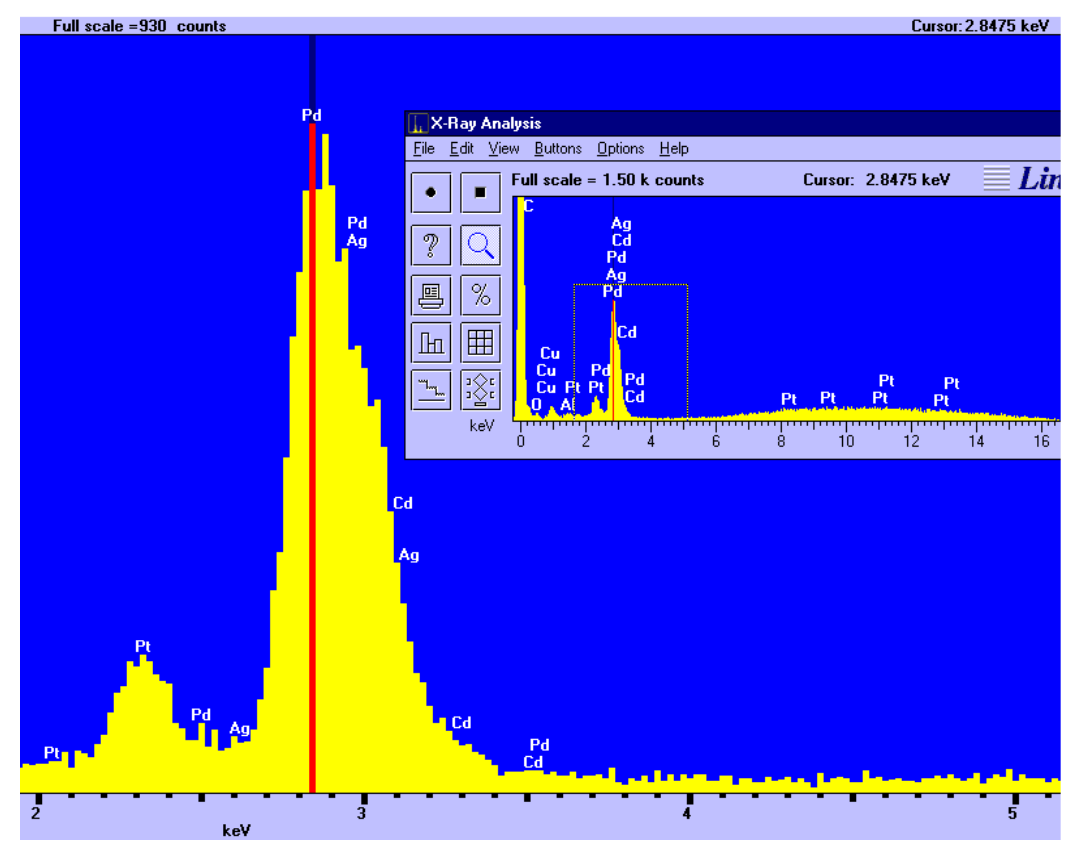


Table 69: Results of elemental analysis of spectrum of FIG. 91, from spot in FIG. 90

\begin{tabular}{|c|c|c|c|}
\hline & $\begin{array}{l}\text { In number } \\
\text { of atoms }\end{array}$ & In mass & $\sigma_{\text {in }}$ mass \\
\hline C & $0.00 \%$ & $0.00 \%$ & $3.35 \%$ \\
\hline O & $38.90 \%$ & $9.88 \%$ & $2.83 \%$ \\
\hline$S$ & $10.55 \%$ & $5.36 \%$ & $0.64 \%$ \\
\hline $\mathrm{Cu}$ & $2.01 \%$ & $2.03 \%$ & $2.11 \%$ \\
\hline $\mathrm{Pd}$ & $47.37 \%$ & $80.00 \%$ & $6.06 \%$ \\
\hline $\mathrm{Ag}$ & $0.62 \%$ & $1.06 \%$ & $3.12 \%$ \\
\hline $\mathrm{Cd}$ & $0.00 \%$ & $0.00 \%$ & $2.77 \%$ \\
\hline $\mathrm{Pt}$ & $0.54 \%$ & $1.67 \%$ & $0.98 \%$ \\
\hline
\end{tabular}

(Surface analysis up to a depth of $\sim 1 \mu \mathrm{m}$. The small $\mathrm{Cu}$ reading was probably a systems peak from the brass stage. The number abundance figures were deduced from the mass results, as the software had returned negative numbers for the former in all cases but carbon).

Table 70: Results of analysis of spectrum of FIG. 91, from spot in FIG. 90, for the metallic elements. An actual separate SEMQuant analysis was conducted for the metallic elements only.

\begin{tabular}{lrrr}
\multicolumn{5}{c}{ In number } & & \\
& of atoms & In mass & \multicolumn{2}{l}{ 位 mass } \\
$\mathrm{Cu}$ & $3.59 \%$ & $2.18 \%$ & $2.26 \%$ \\
$\mathrm{Pd}$ & $82.21 \%$ & $83.26 \%$ & $4.62 \%$ \\
$\mathrm{Ag}$ & $14.19 \%$ & $14.57 \%$ & $3.22 \%$ \\
$\mathrm{Cd}$ & $0.00 \%$ & $0.00 \%$ & $2.87 \%$ \\
$\mathrm{Pt}$ & $0.00 \%$ & $0.00 \%$ & $1.04 \%$
\end{tabular}

(Surface analysis up to a depth of $\sim 1 \mu \mathrm{m}$. The $\mathrm{Cu}$ signal was a systems peak from the brass stage).

FIG. 92 shows another region at the corner of the segment where the D cell cathode had been detached from the Teflon sheathing after electrolysis. This region had two tiny cave-like entrances. 
FIG. 92: Region on the D cell cathode after electrolysis along the edge, near the segment along which the cathode had been detached from the Teflon sheathing. This is the concave side (opposite the spotweld), looking away from the anode.

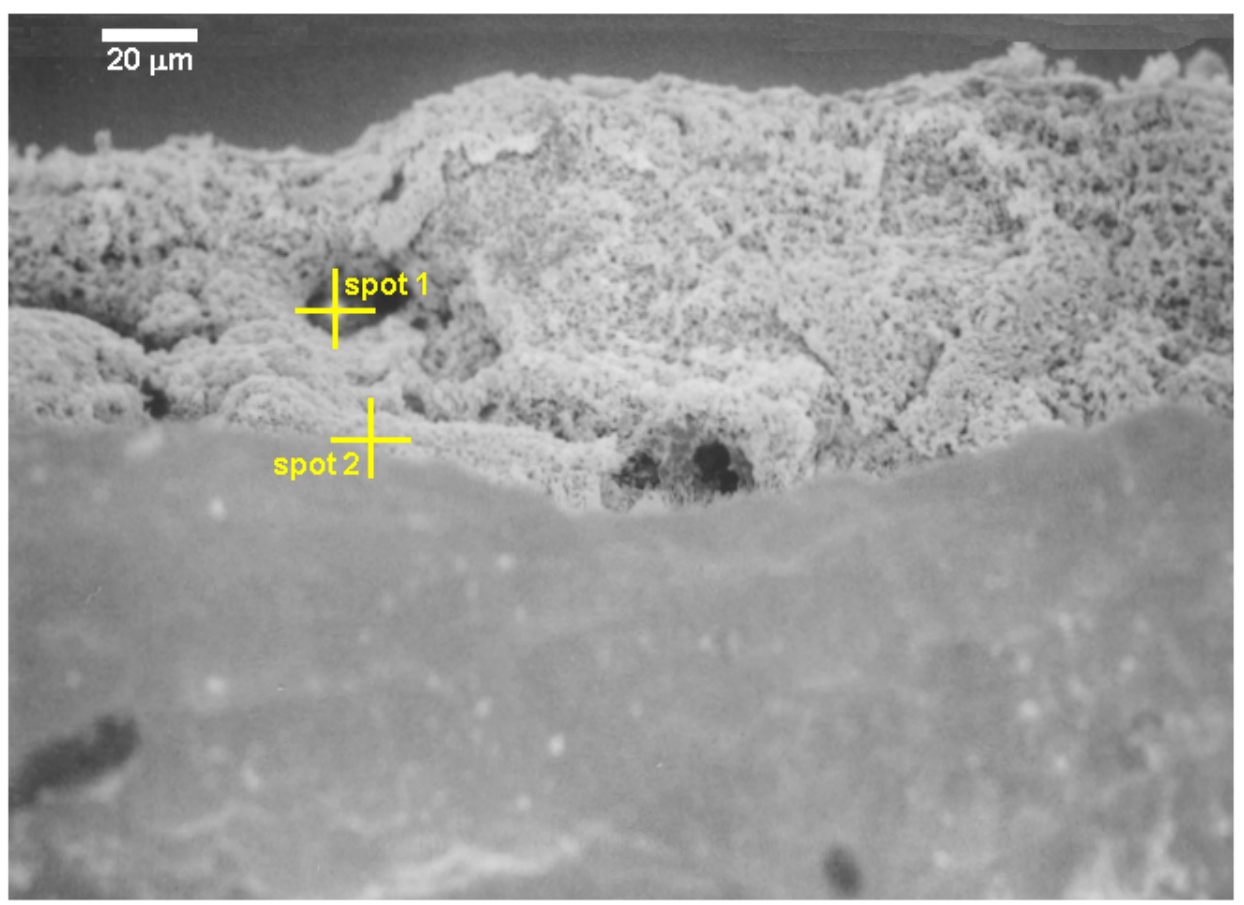

The X-ray acquisition spot was placed in one of these little caves (spot 1), and the subsequent spectrum is displayed in FIG. 93.

The results of the SEMQuant analysis of this spectrum from spot 1 are listed in Tables 71 (for all the elements) and 72 (for the metallic elements only).

There was over 1 atom of silver for every 6 of palladium: 
FIG. 93: X-ray spectrum from spot 1 in FIG. 92.

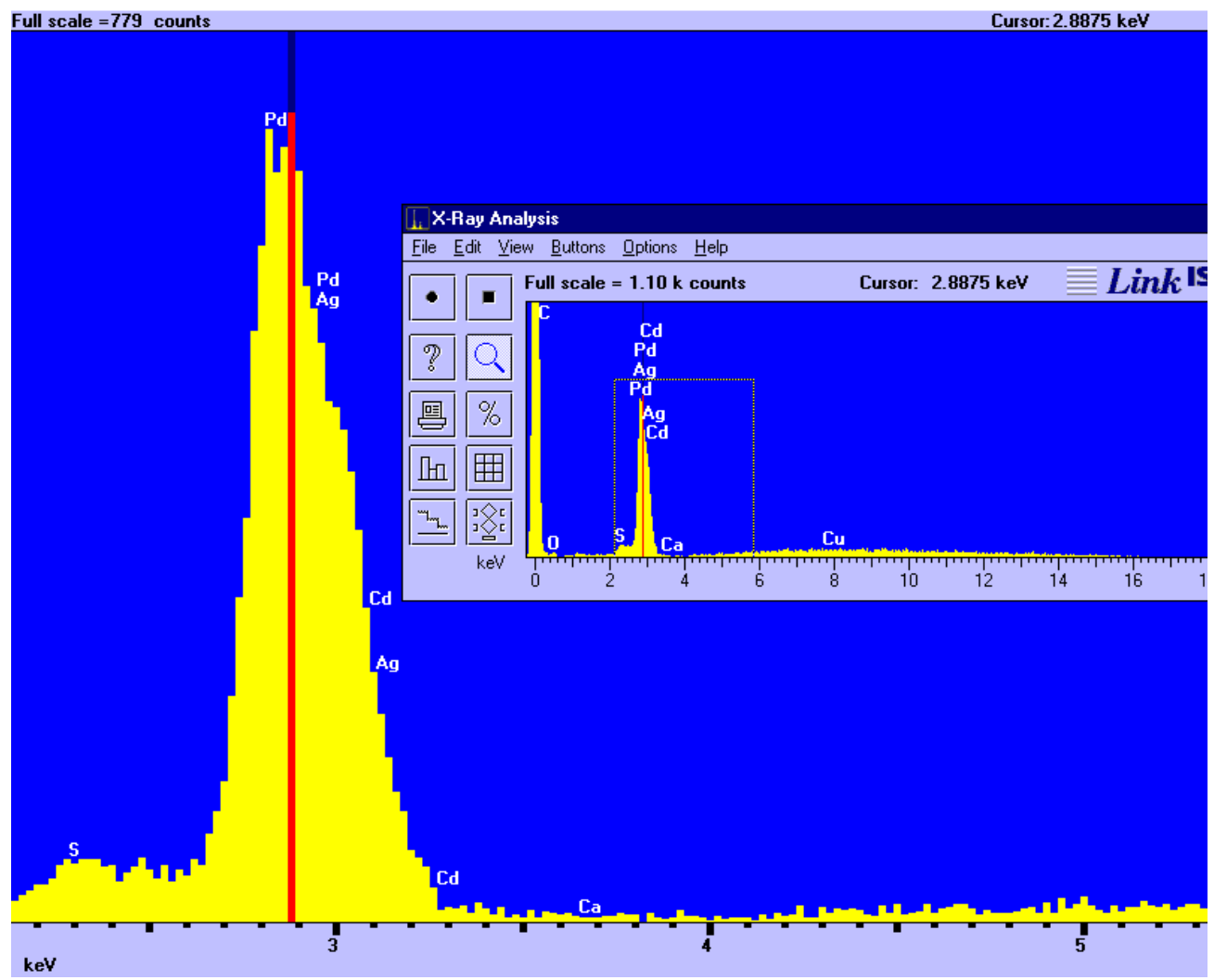

Table 71: Results of elemental analysis of spectrum of FIG. 93, from spot 1 in FIG. 92.

\begin{tabular}{|c|c|c|c|}
\hline & $\begin{array}{l}\text { In number } \\
\text { of atoms }\end{array}$ & In mass & $\sigma_{\text {in }}$ mass \\
\hline C & $80.14 \%$ & $75.18 \%$ & $14.24 \%$ \\
\hline $\mathrm{O}$ & $19.86 \%$ & $24.82 \%$ & $4.50 \%$ \\
\hline S & $0.00 \%$ & $0.00 \%$ & $0.35 \%$ \\
\hline $\mathrm{Cu}$ & $0.00 \%$ & $0.00 \%$ & $1.23 \%$ \\
\hline $\mathrm{Pd}$ & $0.00 \%$ & $0.00 \%$ & $13.05 \%$ \\
\hline $\mathrm{Ag}$ & $0.00 \%$ & $0.00 \%$ & $4.49 \%$ \\
\hline $\mathrm{Cd}$ & $0.00 \%$ & $0.00 \%$ & $2.15 \%$ \\
\hline $\mathrm{Pt}$ & $0.00 \%$ & $0.00 \%$ & $0.54 \%$ \\
\hline
\end{tabular}

(Surface analysis up to a depth of $\sim 1 \mu \mathrm{m}$ ). 
Table 72: Analysis of spectrum of FIG. 93, from spot 1 in FIG. 92, for the metallic elements.

An actual separate SEMQuant analysis was conducted for the metallic elements only.

\begin{tabular}{lrrr}
\multicolumn{5}{c}{ In number } \\
of atoms & In mass & \multicolumn{2}{c}{ 保 } \\
& $1.01 \%$ & $0.60 \%$ & $1.67 \%$ \\
$\mathrm{Cu}$ & $82.34 \%$ & $82.43 \%$ & $4.42 \%$ \\
$\mathrm{Pd}$ & $14.78 \%$ & $15.00 \%$ & $3.50 \%$ \\
$\mathrm{Ag}$ & $1.87 \%$ & $1.97 \%$ & $2.73 \%$ \\
$\mathrm{Cd}$ & $0.00 \%$ & $0.00 \%$ & $0.69 \%$ \\
$\mathrm{Pt}$ & & &
\end{tabular}

(Surface analysis up to a depth of $\sim 1 \mu \mathrm{m}$ ).

FIG. 94 shows the spectrum from spot 2 in FIG. 92, already outside the small hole. The results of the SEMQuant analysis from this spot 2 are listed in Tables 73 (for all the elements) and 74 (for the metallic elements only). Silver had virtually disappeared.

FIG. 94: X-ray spectrum from spot 2 in FIG. 92.

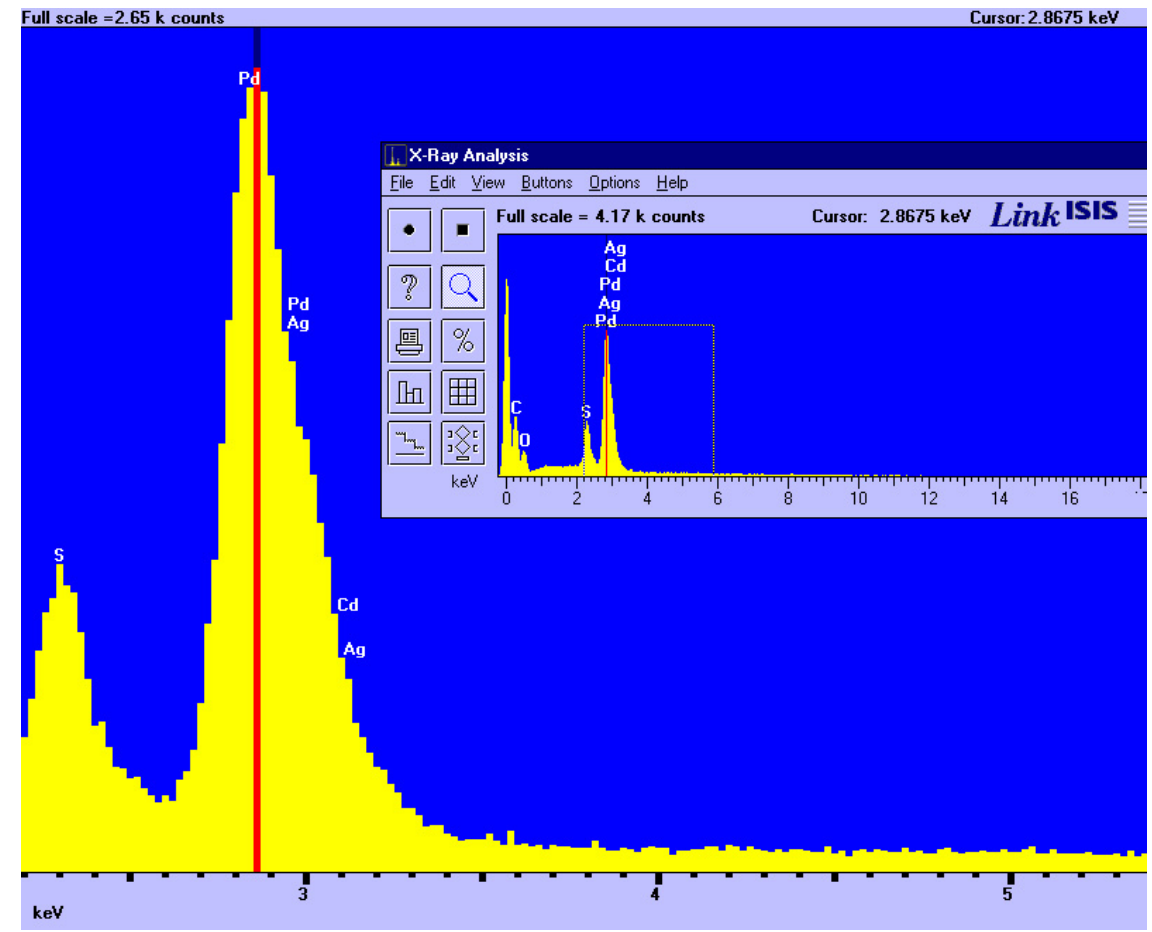


Table 73: Results of elemental analysis of spectrum of FIG. 94, from spot 2 in FIG. 92.

\begin{tabular}{lrrr}
\multicolumn{5}{c}{$\begin{array}{l}\text { In number } \\
\text { of atoms }\end{array}$} & In mass & \multicolumn{2}{c}{ 更 mass } \\
C & $33.90 \%$ & $14.17 \%$ & $0.98 \%$ \\
$\mathrm{O}$ & $46.07 \%$ & $25.64 \%$ & $1.46 \%$ \\
$\mathrm{~S}$ & $5.49 \%$ & $6.12 \%$ & $0.28 \%$ \\
$\mathrm{Cu}$ & $0.00 \%$ & $0.00 \%$ & $0.35 \%$ \\
$\mathrm{Pd}$ & $14.30 \%$ & $52.93 \%$ & $1.54 \%$ \\
$\mathrm{Ag}$ & $0.16 \%$ & $0.62 \%$ & $1.28 \%$ \\
$\mathrm{Cd}$ & $0.00 \%$ & $0.00 \%$ & $0.98 \%$ \\
$\mathrm{Pt}$ & $0.08 \%$ & $0.54 \%$ & $0.45 \%$
\end{tabular}

(Surface analysis up to a depth of $\sim 1 \mu \mathrm{m}$ ).

Table 74: Results of analysis of spectrum of FIG. 94, from spot 2 in FIG. 92, for the metallic elements. An actual separate SEMQuant analysis was conducted for the metallic elements only.

\begin{tabular}{lrrr}
\multicolumn{5}{c}{$\begin{array}{l}\text { In number } \\
\text { of atoms }\end{array}$} & In mass & \multicolumn{2}{c}{$\sigma_{\text {in }}$ mass } \\
Cu & $2.38 \%$ & $1.44 \%$ & $0.90 \%$ \\
$\mathrm{Pd}$ & $96.40 \%$ & $97.32 \%$ & $5.09 \%$ \\
$\mathrm{Ag}$ & $1.22 \%$ & $1.24 \%$ & $3.85 \%$ \\
$\mathrm{Cd}$ & $0.00 \%$ & $0.00 \%$ & $0.00 \%$ \\
$\mathrm{Pt}$ & $0.00 \%$ & $0.00 \%$ & $1.22 \%$
\end{tabular}

(Surface analysis up to a depth of $\sim 1 \mu \mathrm{m}$ ).

FIG. 95 shows two selected areas from which X-rays were acquired on a region around the center of the $\mathrm{D}$ cell cathode on its concave spotweld side where the deposit of substance had thickened and there were changes in topography. The spectrum from selected area 1 is displayed in FIG. 96; the results of the quantitative analysis of this spectrum are listed in Tables 75 (for all the elements) and 76 (for 
the metallic elements only). The spectrum from selected area 2 is displayed in FIG. 97; the results of the quantitative analysis of this spectrum are listed in Tables 77 (for all the elements) and 78 (for the metallic elements only).

FIG. 95: Localized change in topography on the D cell cathode after electrolysis. This was the concave side opposite the spotweld, looking away from the anode.

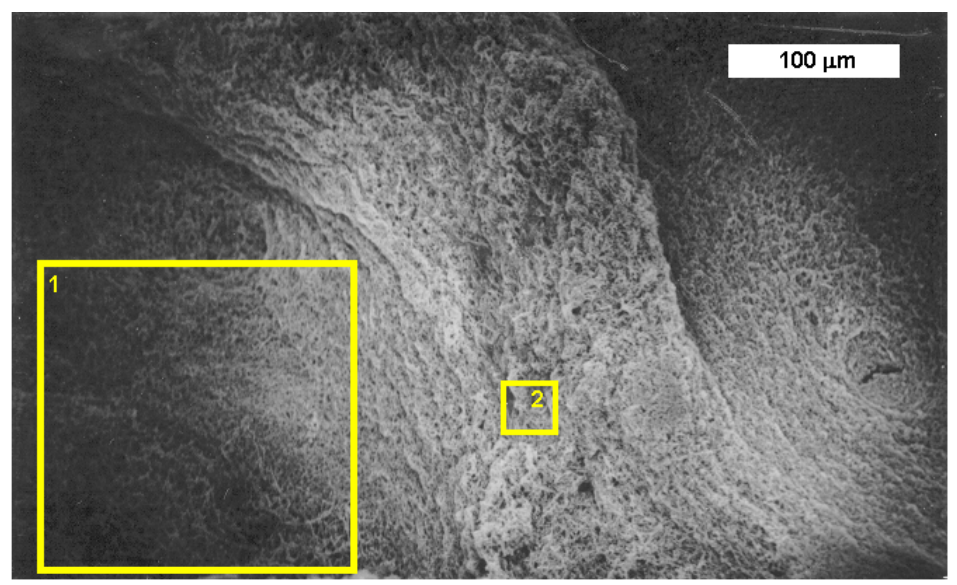

FIG. 96: X-ray spectrum from selected area 1 in FIG. 95.

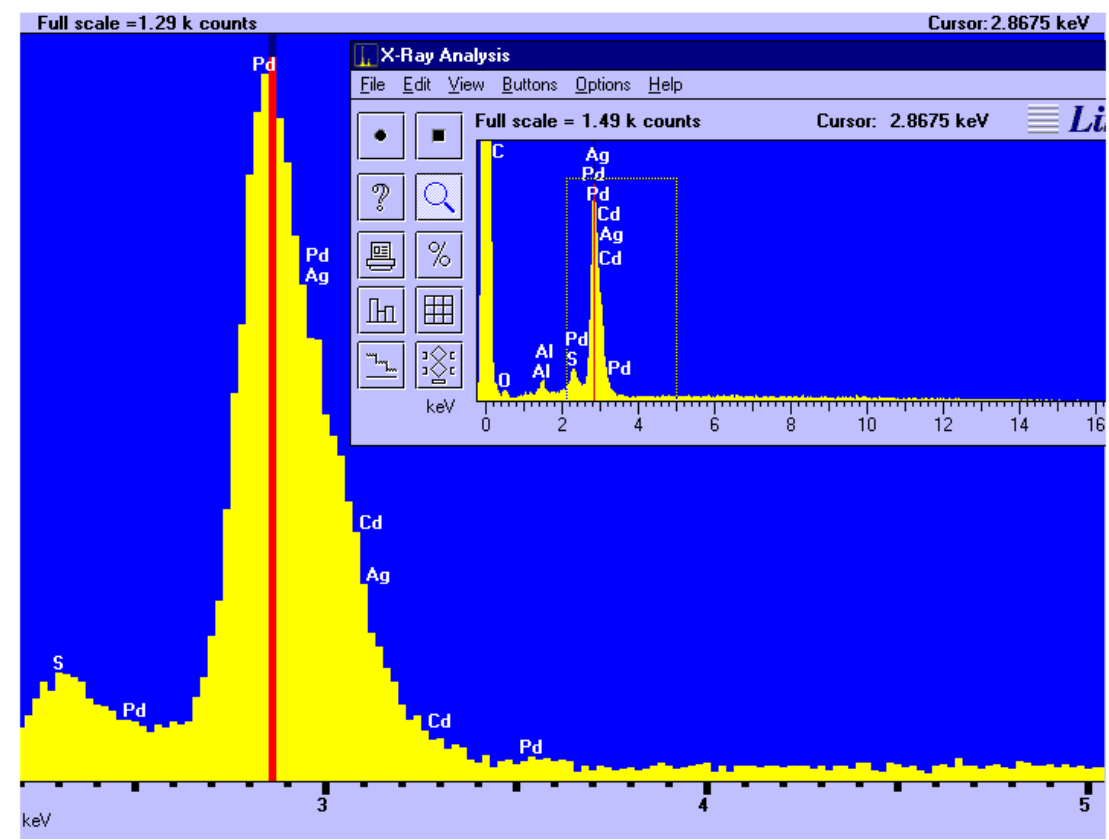


Table 75: Results of elemental analysis of spectrum of FIG. 96 from selected area 1 in FIG.

95.

\begin{tabular}{lrrr}
\multicolumn{5}{c}{$\begin{array}{l}\text { In number } \\
\text { of atoms }\end{array}$} & In mass & \multicolumn{1}{c}{ 佂 mass } \\
C & $0.00 \%$ & $0.00 \%$ & $3.15 \%$ \\
$\mathrm{O}$ & $49.28 \%$ & $13.69 \%$ & $1.82 \%$ \\
$\mathrm{~S}$ & $5.76 \%$ & $3.20 \%$ & $0.40 \%$ \\
$\mathrm{Cu}$ & $0.72 \%$ & $0.79 \%$ & $0.81 \%$ \\
$\mathrm{Pd}$ & $42.30 \%$ & $78.14 \%$ & $5.02 \%$ \\
$\mathrm{Ag}$ & $1.57 \%$ & $2.95 \%$ & $2.45 \%$ \\
$\mathrm{Cd}$ & $0.00 \%$ & $0.00 \%$ & $1.90 \%$ \\
$\mathrm{Pt}$ & $0.36 \%$ & $1.22 \%$ & $0.73 \%$
\end{tabular}

(Surface analysis up to a depth of $\sim 1 \mu \mathrm{m}$. The number abundance figures were deduced from the mass results, as the software had returned negative numbers for the former in all cases but carbon).

Table 76: Analysis of spectrum of FIG. 96, from selected area 1 in FIG. 95, for the metallic elements. An actual separate SEMQuant analysis was conducted for these metallic elements only.

\begin{tabular}{lrrr}
\multicolumn{5}{c}{$\begin{array}{l}\text { In number } \\
\text { of atoms }\end{array}$} & In mass & \multicolumn{1}{c}{ 任 mass } \\
$\mathrm{Cu}$ & $1.75 \%$ & $1.05 \%$ & $1.01 \%$ \\
$\mathrm{Pd}$ & $94.24 \%$ & $94.85 \%$ & $4.00 \%$ \\
$\mathrm{Ag}$ & $3.95 \%$ & $4.02 \%$ & $3.01 \%$ \\
$\mathrm{Cd}$ & $0.07 \%$ & $0.08 \%$ & $2.33 \%$ \\
$\mathrm{Pt}$ & $0.00 \%$ & $0.00 \%$ & $0.88 \%$
\end{tabular}

(Surface analysis up to a depth of $\sim 1 \mu \mathrm{m}$ ) 
FIG. 97: X-ray spectrum from selected area 2 in FIG. 95.

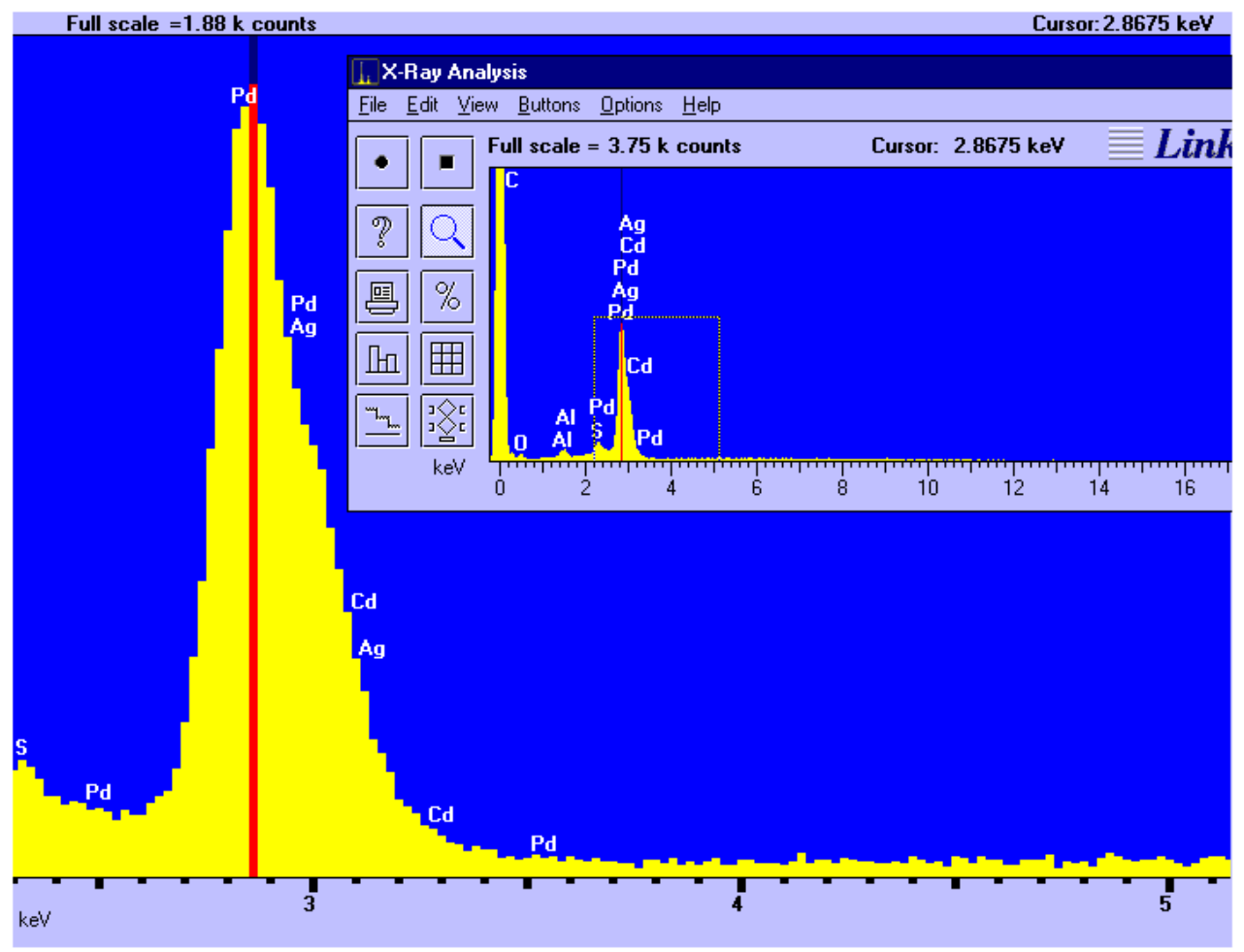

Table 77: Results of elemental analysis of spectrum of FIG. 97, from selected area 2 in FIG. 95

\begin{tabular}{lrrr}
\multicolumn{5}{c}{ In number } \\
\multicolumn{5}{c}{ of atoms } & In mass & \multicolumn{1}{c}{ 更 mass } \\
$\mathrm{C}$ & $0.00 \%$ & $0.00 \%$ & $1.99 \%$ \\
$\mathrm{O}$ & $47.32 \%$ & $12.68 \%$ & $1.55 \%$ \\
$\mathrm{~S}$ & $5.63 \%$ & $3.02 \%$ & $0.32 \%$ \\
$\mathrm{Cu}$ & $0.00 \%$ & $0.00 \%$ & $0.65 \%$ \\
$\mathrm{Pd}$ & $45.02 \%$ & $80.22 \%$ & $3.90 \%$ \\
$\mathrm{Ag}$ & $1.73 \%$ & $3.12 \%$ & $2.09 \%$ \\
$\mathrm{Cd}$ & $0.00 \%$ & $0.01 \%$ & $1.62 \%$ \\
$\mathrm{Pt}$ & $0.29 \%$ & $0.95 \%$ & $0.63 \%$
\end{tabular}

(Surface analysis up to a depth of $\sim 1 \mu \mathrm{m}$. The number abundance figures were deduced from the mass results, as the software had returned negative numbers for the former in all cases but carbon). 
Table 78: Results of analysis of spectrum of FIG. 97, from selected area 2 in FIG. 95, for the metallic elements. An actual separate SEMQuant analysis was conducted for these metallic elements only.

\begin{tabular}{lrrr}
\multicolumn{5}{c}{ In number } & & \\
& of atoms & In mass & \multicolumn{1}{c}{ 而 mass } \\
$\mathrm{Cu}$ & $0.00 \%$ & $0.00 \%$ & $0.79 \%$ \\
$\mathrm{Pd}$ & $95.80 \%$ & $95.75 \%$ & $3.37 \%$ \\
$\mathrm{Ag}$ & $4.04 \%$ & $4.09 \%$ & $2.51 \%$ \\
$\mathrm{Cd}$ & $0.16 \%$ & $0.17 \%$ & $1.94 \%$ \\
$\mathrm{Pt}$ & $0.00 \%$ & $0.00 \%$ & $0.74 \%$
\end{tabular}

(Surface analysis up to a depth of $\sim 1 \mu \mathrm{m}$ )

A region with an oval cleft of axes $28 \mu \mathrm{m} \times 7 \mu \mathrm{m}$ was thought to merit interest. The region in question is shown in FIG. 98, and was on the convex spotweld side of the D cathode (looking away from the anode), only $0.2 \mathrm{~mm}$ from the lower tip. The region was in an area covered with the deposit of substance. X-rays were acquired from 5 different spots. 
FIG. 98: Micrograph of deposit-covered region with small crannies on the (convex) spotweld side of the $D$ cell cathode, facing the anode. The 5 spots from which X-rays were acquired are shown.

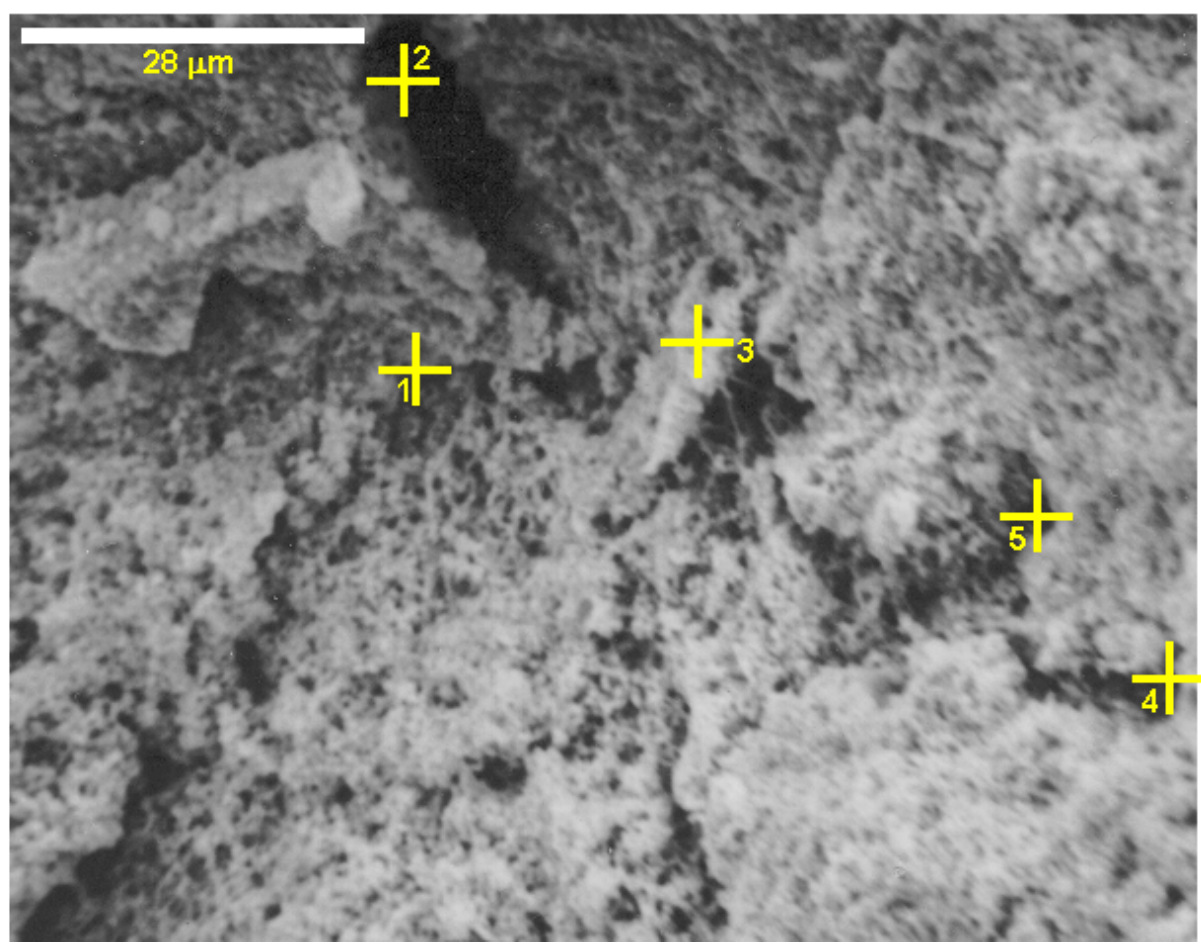

Spot 1 was on a moderately-depressed area just off the lower entrance of the cleft. The spectrum from spot 1 is displayed in FIG. 99. The results of the SEMQuant analysis of this spot 1 are listed in Table 79, for the metallic elements only. When carbon was included in the analysis SEMQuant returned asterisks for the elemental abundances because the $\mathrm{C}$ peak went off-scale and possibly swamped all the other signals. 
FIG. 99: X-ray spectrum from spot 1 in FIG. 98.

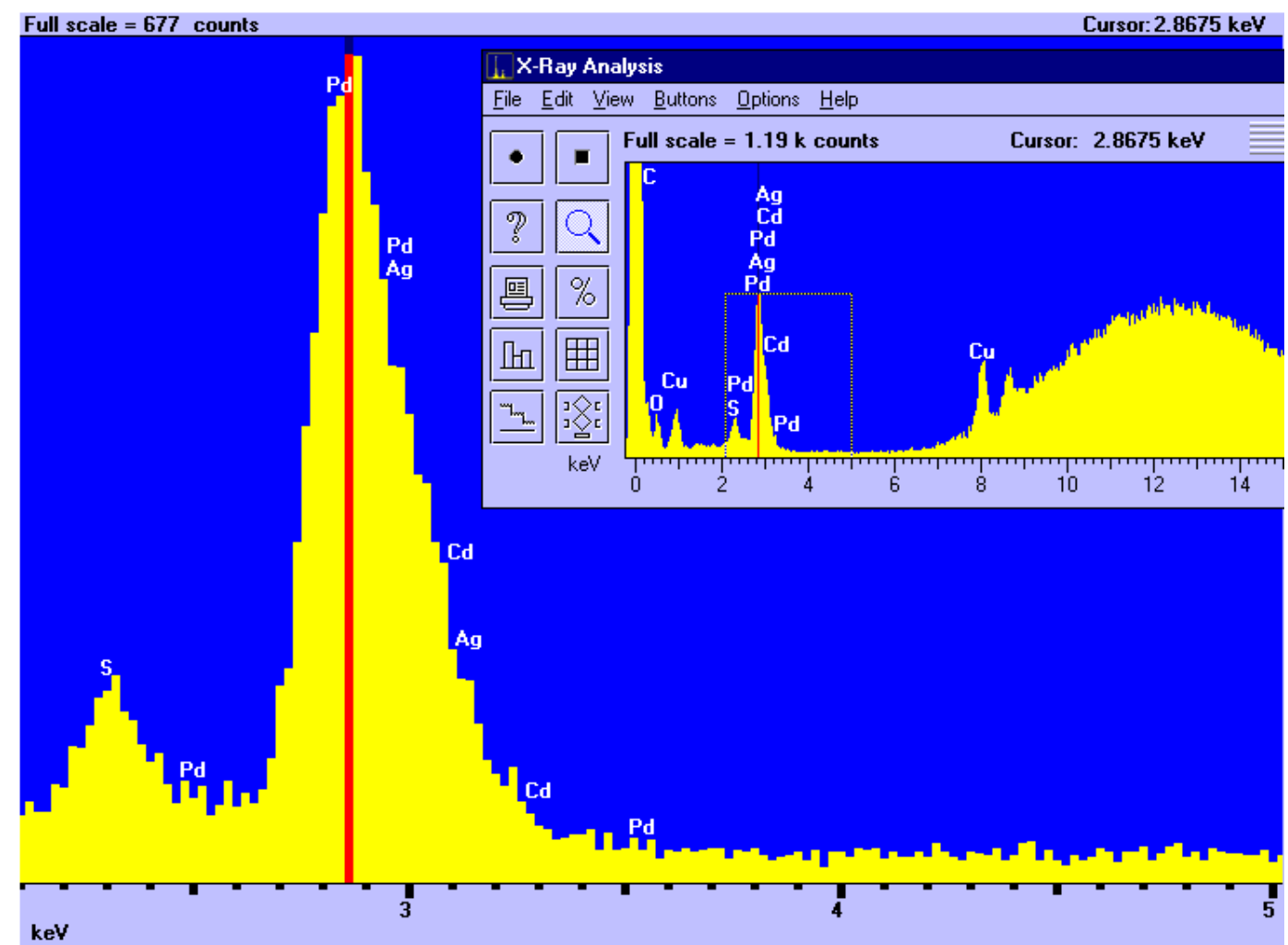

Table 79: Results of analysis of spectrum of FIG. 99, from spot 1 in FIG. 98, for the metallic elements. An actual separate SEMQuant analysis was conducted for the metallic elements only.

\begin{tabular}{lrrr}
\multicolumn{5}{c}{$\begin{array}{l}\text { In number } \\
\text { of atoms }\end{array}$} & In mass & \multicolumn{1}{c}{ 位 mass } \\
$\mathrm{Cu}$ & $53.91 \%$ & $41.09 \%$ & $2.59 \%$ \\
$\mathrm{Pd}$ & $42.72 \%$ & $54.53 \%$ & $2.86 \%$ \\
$\mathrm{Ag}$ & $3.26 \%$ & $4.22 \%$ & $2.56 \%$ \\
$\mathrm{Cd}$ & $0.11 \%$ & $0.16 \%$ & $2.03 \%$ \\
$\mathrm{Pt}$ & $0.00 \%$ & $0.00 \%$ & $0.95 \%$
\end{tabular}

(Surface analysis up to a depth of $\sim 1 \mu \mathrm{m}$. The $\mathrm{Cu}$ signal was probably a systems peak from the brass stage.) 
Spot 2 was inside the oval cleft. The spectrum from this spot 2 is displayed in FIG. 100. The results of the SEMQuant analysis of this spot 2 are listed in Table 80, for all the elements, and 81 for the metallic elements only. There was over 1 atom of $\mathrm{Ag}$ for 4 of Pd.

FIG. 100: X-ray spectrum from spot 2 in FIG. 98.

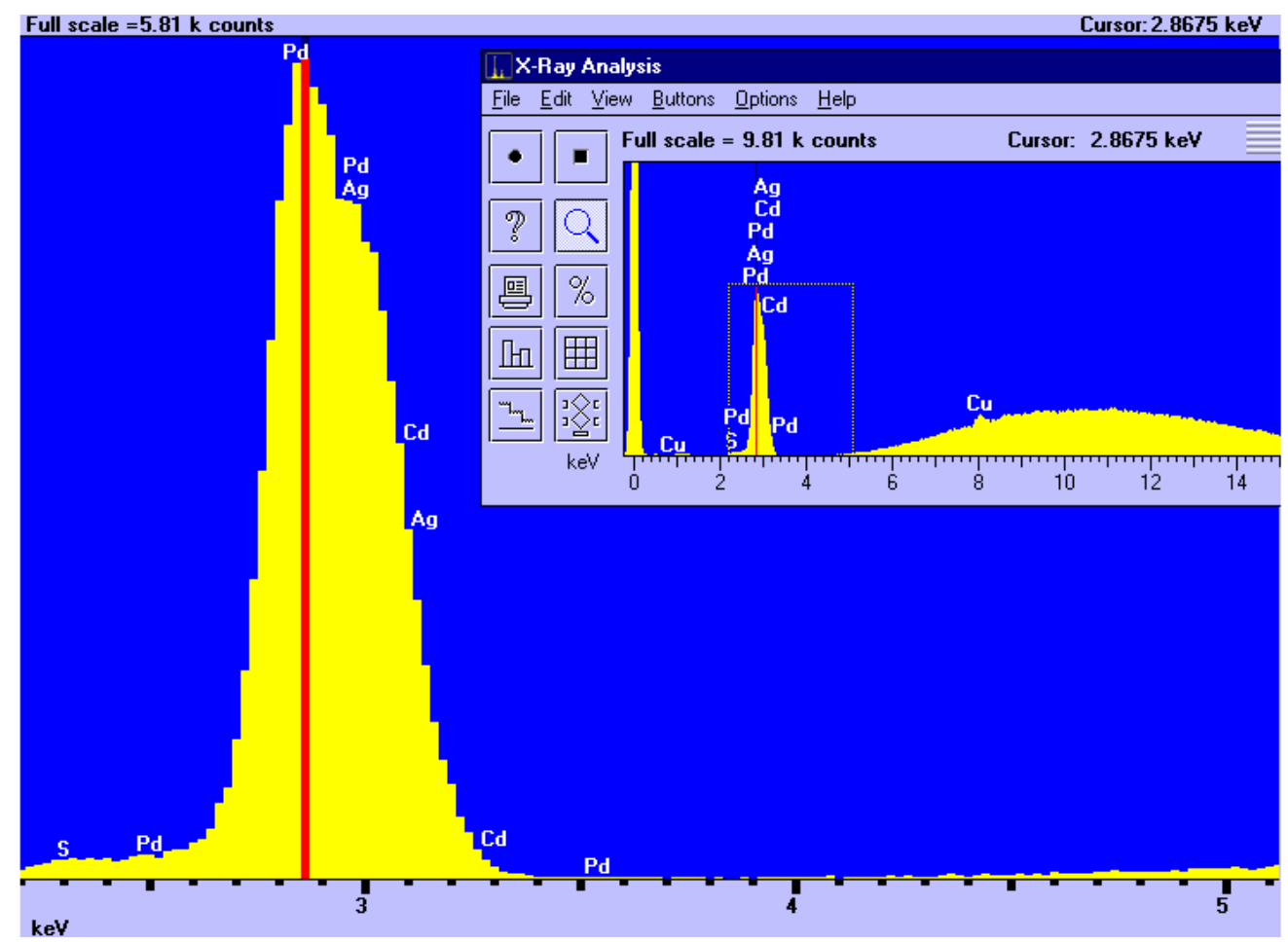

Table 80: Results of elemental analysis of spectrum of FIG. 100, from spot 2 in FIG. 98.

\begin{tabular}{lrrr}
\multicolumn{5}{c}{ In number } & & \\
& of atoms & In mass & \multicolumn{1}{l}{$\sigma_{\text {in }}$ mass } \\
$\mathrm{C}$ & $0.00 \%$ & $0.00 \%$ & $0.30 \%$ \\
$\mathrm{O}$ & $12.68 \%$ & $2.29 \%$ & $0.41 \%$ \\
$\mathrm{~S}$ & $2.03 \%$ & $0.73 \%$ & $0.07 \%$ \\
$\mathrm{Cu}$ & $11.50 \%$ & $8.22 \%$ & $1.02 \%$ \\
$\mathrm{Pd}$ & $57.23 \%$ & $68.53 \%$ & $1.33 \%$ \\
$\mathrm{Ag}$ & $16.43 \%$ & $19.94 \%$ & $0.81 \%$ \\
$\mathrm{Cd}$ & $0.00 \%$ & $0.00 \%$ & $0.65 \%$ \\
$\mathrm{Pt}$ & $0.13 \%$ & $0.29 \%$ & $0.13 \%$
\end{tabular}


(Surface analysis up to a depth of $\sim 1 \mu \mathrm{m}$. The $\mathrm{Cu}$ reading was probably a systems peak from the brass stage. The $\mathrm{C}$ result from the software was actually a large negative value so a zero is listed here in the normalized table)

Table 81: Results of analysis of spectrum of FIG. 100, from spot 2 in FIG. 98, for the metallic elements. An actual separate SEMQuant analysis was conducted for the metallic elements only.

\begin{tabular}{lrrr}
\multicolumn{5}{c}{$\begin{array}{l}\text { In number } \\
\text { of atoms }\end{array}$} & In mass & \multicolumn{1}{c}{ 佂 mass } \\
Cu & $13.64 \%$ & $8.59 \%$ & $1.07 \%$ \\
$\mathrm{Pd}$ & $67.03 \%$ & $70.73 \%$ & $1.27 \%$ \\
$\mathrm{Ag}$ & $19.33 \%$ & $20.68 \%$ & $0.83 \%$ \\
$\mathrm{Cd}$ & $0.00 \%$ & $0.00 \%$ & $0.66 \%$ \\
$\mathrm{Pt}$ & $0.00 \%$ & $0.00 \%$ & $0.12 \%$
\end{tabular}

(Surface analysis up to a depth of $\sim 1 \mu \mathrm{m}$. The $\mathrm{Cu}$ reading was probably a systems peak from the brass stage.)

Spot 3 in FIG. 98 was on a little ridge-like elevation just off the entrance of the oval cleft. The spectrum from this spot 3 is displayed in FIG. 101. The results of the SEMQuant analysis of this spot 3 are listed in Table 82, for all the elements, and 83, for the metallic elements only. The number abundance of Ag was $4.63 \pm 1.81 \%$ compared with $53.55 \pm 2.14 \%$ for $\mathrm{Pd}$, ignoring the non-metallic elements.

There was over 1 atom of $\mathrm{Ag}$ for 12 of Pd. 
FIG. 101: X-ray spectrum from spot 3 in FIG. 98.

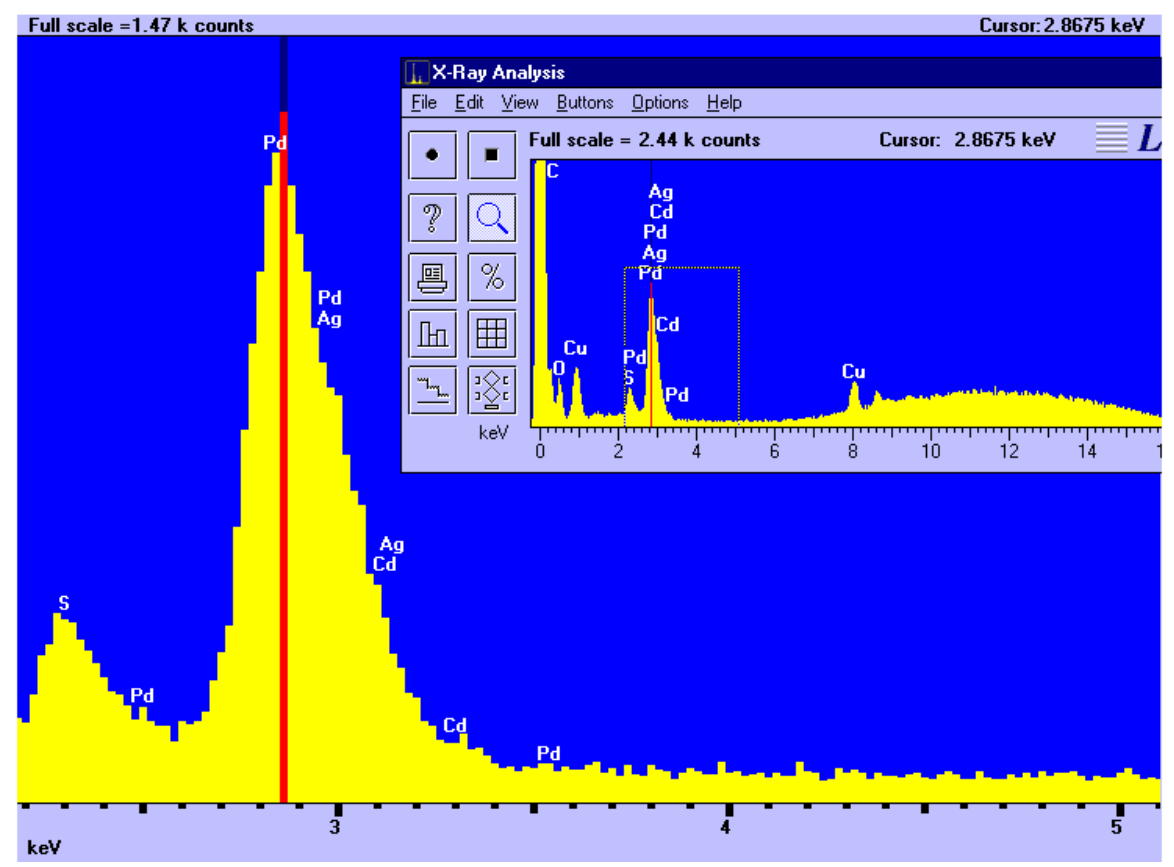

Table 82: Results of elemental analysis of spectrum of FIG. 101, from spot 3 in FIG. 98.

\begin{tabular}{lrrr}
\multicolumn{5}{c}{ In number } \\
of atoms & In mass & \multicolumn{1}{c}{ 位 mass } \\
$\mathrm{C}$ & $0.00 \%$ & $0.00 \%$ & $14.97 \%$ \\
$\mathrm{O}$ & $69.30 \%$ & $30.45 \%$ & $4.82 \%$ \\
$\mathrm{~S}$ & $3.86 \%$ & $3.39 \%$ & $0.64 \%$ \\
$\mathrm{Cu}$ & $10.95 \%$ & $19.11 \%$ & $3.17 \%$ \\
$\mathrm{Pd}$ & $14.28 \%$ & $41.74 \%$ & $7.05 \%$ \\
$\mathrm{Ag}$ & $1.14 \%$ & $3.38 \%$ & $1.40 \%$ \\
$\mathrm{Cd}$ & $0.26 \%$ & $0.79 \%$ & $1.15 \%$ \\
$\mathrm{Pt}$ & $0.21 \%$ & $1.13 \%$ & $0.57 \%$
\end{tabular}

(Surface analysis up to a depth of $\sim 1 \mu \mathrm{m}$. The $\mathrm{Cu}$ signal was probably a systems peak from the brass stage. The software actually returned asterisks for the $\mathrm{C}$ mass concentration and negative values for the number concentrations of the other elements, so the number abundance values were inferred indirectly from the mass abundance results) 
Table 83: Results of analysis of spectrum of FIG. 101, from spot 3 in FIG. 98, for the metallic elements. An actual separate SEMQuant analysis was conducted for the metallic elements only.

\begin{tabular}{lrrr}
\multicolumn{5}{c}{$\begin{array}{l}\text { In number } \\
\text { of atoms }\end{array}$} & In mass & \multicolumn{1}{c}{ 位 mass } \\
$\mathrm{Cu}$ & $40.59 \%$ & $28.94 \%$ & $1.84 \%$ \\
$\mathrm{Pd}$ & $53.55 \%$ & $63.91 \%$ & $2.55 \%$ \\
$\mathrm{Ag}$ & $4.63 \%$ & $5.60 \%$ & $2.19 \%$ \\
$\mathrm{Cd}$ & $1.23 \%$ & $1.55 \%$ & $1.76 \%$ \\
$\mathrm{Pt}$ & $0.00 \%$ & $0.00 \%$ & $0.86 \%$
\end{tabular}

(Surface analysis up to a depth of $\sim 1 \mu \mathrm{m}$. The $\mathrm{Cu}$ signal was probably a systems peak from the brass stage.)

Spot 4 in FIG. 98 was on a little depression. The spectrum from this spot 4 is displayed in FIG. 102. The results of the SEMQuant analysis of this spot 4 are listed in Table 84, for all the elements, and 85, for the metallic elements only. The number abundance of $\mathrm{Ag}$ was $16.37 \pm 0.81 \%$ compared with $73.87 \pm 1.17 \%$ for $\mathrm{Pd}$, ignoring the non-metallic elements.

There was over 1 atom of $\mathrm{Ag}$ for 5 of Pd. 
FIG. 102: X-ray spectrum from spot 4 in FIG. 98.

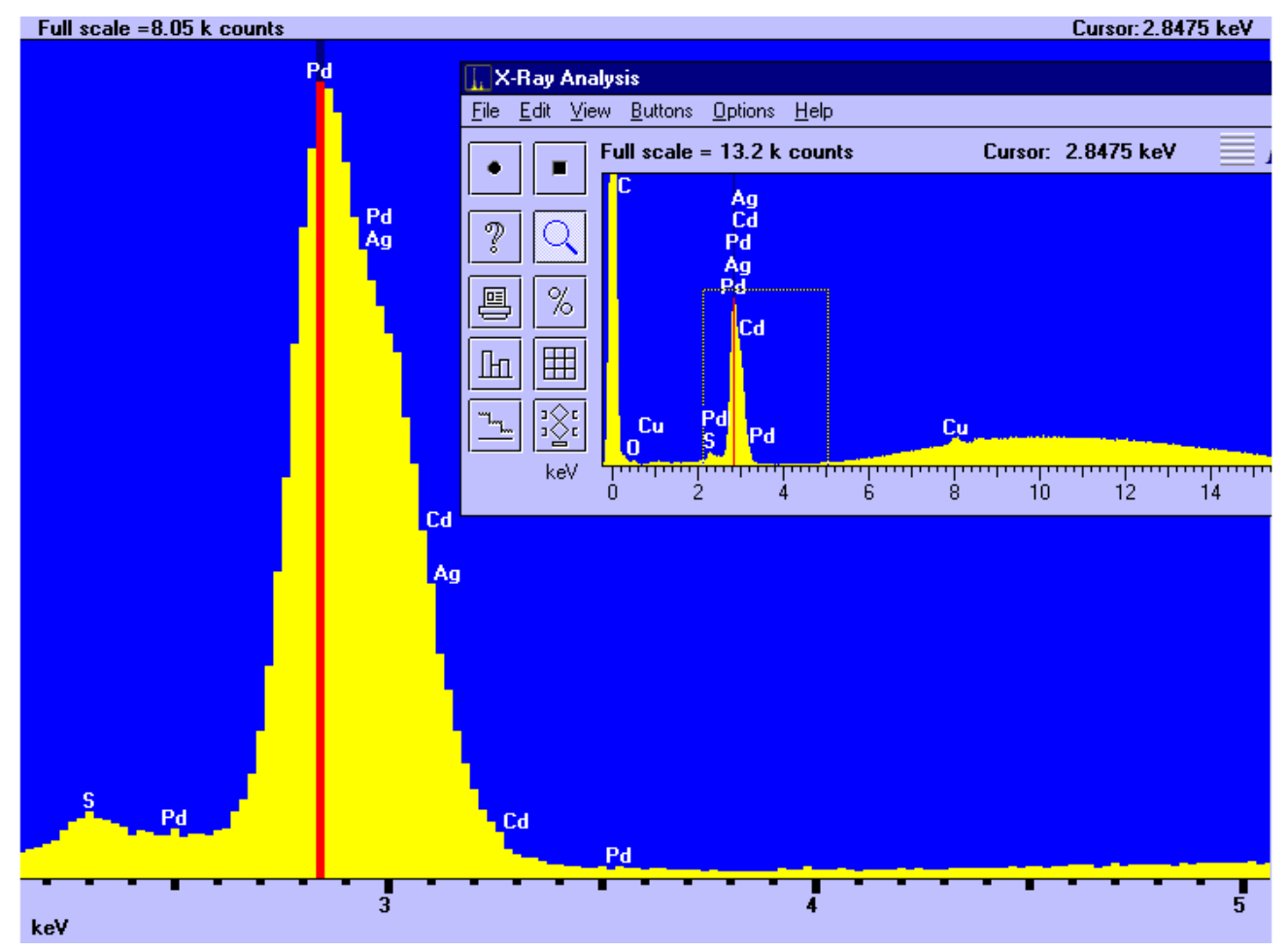

Table 84: Results of elemental analysis of spectrum of FIG. 102, from spot 4 in FIG. 98.

\begin{tabular}{lrrr}
\multicolumn{5}{c}{$\begin{array}{l}\text { In number } \\
\text { of atoms }\end{array}$} & In mass & \multicolumn{1}{c}{ 而 mass } \\
$\mathrm{C}$ & $0.00 \%$ & $0.00 \%$ & $0.53 \%$ \\
$\mathrm{O}$ & $27.21 \%$ & $5.69 \%$ & $0.60 \%$ \\
$\mathrm{~S}$ & $3.92 \%$ & $1.64 \%$ & $0.10 \%$ \\
$\mathrm{Cu}$ & $6.60 \%$ & $5.48 \%$ & $0.76 \%$ \\
$\mathrm{Pd}$ & $50.82 \%$ & $70.67 \%$ & $1.37 \%$ \\
$\mathrm{Ag}$ & $11.14 \%$ & $15.71 \%$ & $0.80 \%$ \\
$\mathrm{Cd}$ & $0.00 \%$ & $0.00 \%$ & $0.69 \%$ \\
$\mathrm{Pt}$ & $0.32 \%$ & $0.81 \%$ & $0.21 \%$
\end{tabular}

(Surface analysis up to a depth of $\sim 1 \mu \mathrm{m}$. The software actually returned asterisks for the Pd number concentration and a negative number for the mass abundance of $\mathrm{C}$ : the listed number abundance results were derived from the mass results of the software) 
Table 85: Results of analysis of spectrum of FIG. 102, from spot 4 in FIG. 98, for the metallic elements.

\begin{tabular}{lrrr}
\multicolumn{5}{c}{ In number } \\
of atoms & In mass & \multicolumn{1}{c}{ 任 mass } \\
$\mathrm{Cu}$ & $9.77 \%$ & $6.05 \%$ & $0.84 \%$ \\
$\mathrm{Pd}$ & $73.87 \%$ & $76.71 \%$ & $1.22 \%$ \\
$\mathrm{Ag}$ & $16.37 \%$ & $17.23 \%$ & $0.86 \%$ \\
$\mathrm{Cd}$ & $0.00 \%$ & $0.00 \%$ & $0.74 \%$ \\
$\mathrm{Pt}$ & $0.00 \%$ & $0.00 \%$ & $0.21 \%$
\end{tabular}

(Surface analysis up to a depth of $\sim 1 \mu \mathrm{m}$. The $\mathrm{Cu}$ signal was a systems peak from the brass stage.)

Spot 5 in FIG. 98 was on a point of medium elevation. The spectrum from spot 5 is displayed in FIG. 103. The results of the SEMQuant analysis of this spot 5 are listed in Table 86, for all the elements, and 87, for the metallic elements only.

The number abundance of $\mathrm{Ag}$ was $7.55 \pm 1.59 \%$ compared with $70.55 \pm 2.21 \%$ for the abundance of $\mathrm{Pd}$, ignoring the non-metallic elements.

There was over 1 atom of $\mathrm{Ag}$ for 10 of $\mathrm{Pd}$. 
FIG. 103: X-ray spectrum from spot 5 in FIG. 98.

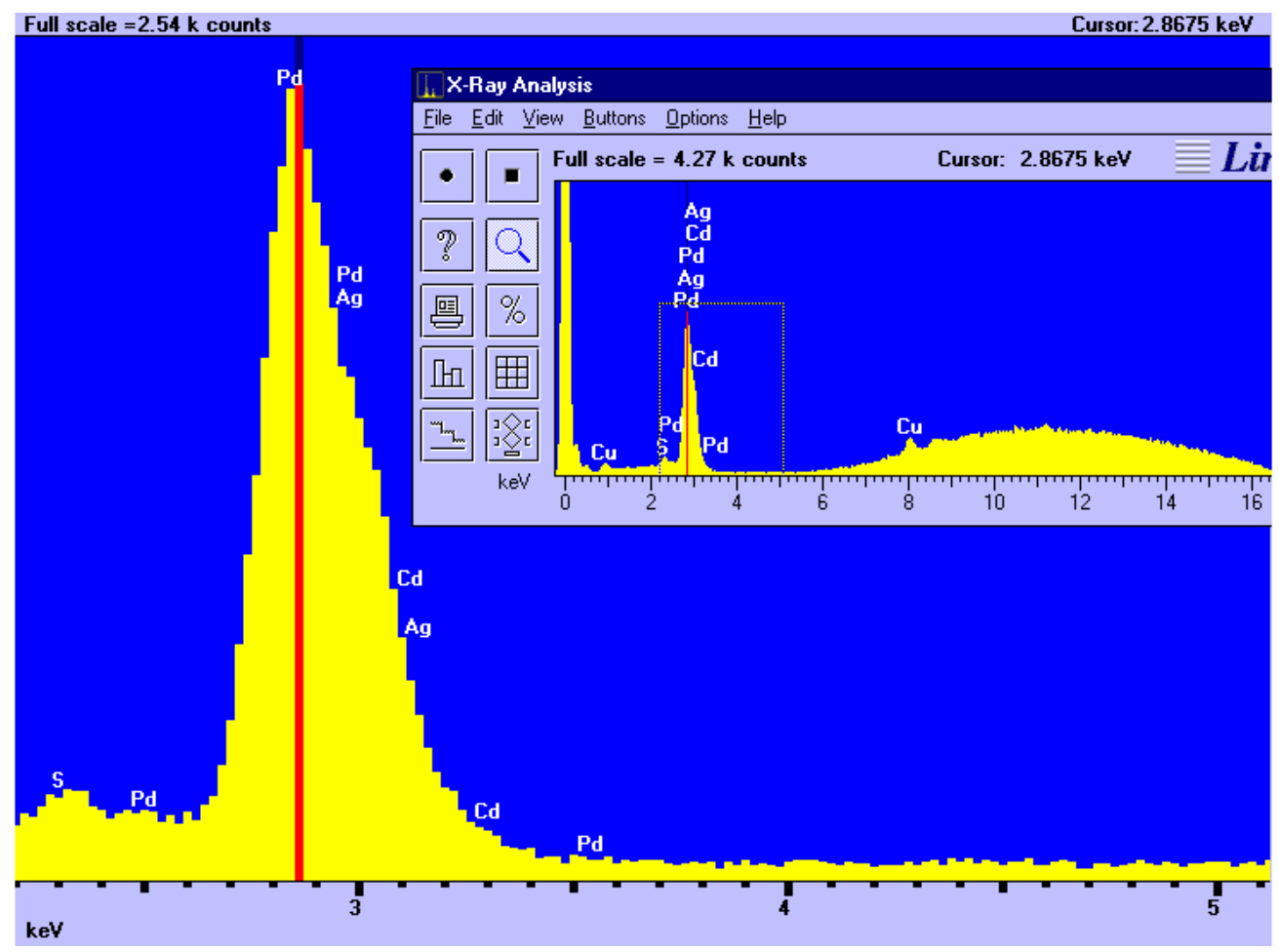

Table 86: Results of elemental analysis of spectrum of FIG. 103, from spot 5 in FIG. 98.

\begin{tabular}{lrrr}
\multicolumn{5}{c}{$\begin{array}{l}\text { In number } \\
\text { of atoms }\end{array}$} & In mass & \multicolumn{1}{l}{ 位 mass } \\
$\mathrm{C}$ & $0.00 \%$ & $0.00 \%$ & $2.01 \%$ \\
$\mathrm{O}$ & $23.86 \%$ & $5.06 \%$ & $1.47 \%$ \\
$\mathrm{~S}$ & $4.48 \%$ & $1.90 \%$ & $0.24 \%$ \\
$\mathrm{Cu}$ & $15.38 \%$ & $12.96 \%$ & $1.45 \%$ \\
$\mathrm{Pd}$ & $50.44 \%$ & $71.14 \%$ & $3.37 \%$ \\
$\mathrm{Ag}$ & $5.31 \%$ & $7.60 \%$ & $1.62 \%$ \\
$\mathrm{Cd}$ & $0.00 \%$ & $0.00 \%$ & $1.35 \%$ \\
$\mathrm{Pt}$ & $0.52 \%$ & $1.34 \%$ & $0.54 \%$
\end{tabular}

(Surface analysis up to a depth of $\sim 1 \mu \mathrm{m}$. The small $\mathrm{Cu}$ reading was probably a systems peak from the brass stage. The software returned a negative value for the $\mathrm{C}$ mass abundance, and negative values for all the number elemental abundances except for $\mathrm{C}$; the listed number abundances were deduced from the software results for the mass abundances) 
Table 87: Results of analysis of spectrum of FIG. 103, from spot 5 in FIG. 98, for the metallic elements. An actual separate SEMQuant analysis was conducted for the metallic elements only.

\begin{tabular}{lrrr}
\multicolumn{5}{c}{$\begin{array}{l}\text { In number } \\
\text { of atoms }\end{array}$} & In mass & \multicolumn{1}{c}{ 位 mass } \\
$\mathrm{Cu}$ & $21.89 \%$ & $14.32 \%$ & $1.57 \%$ \\
$\mathrm{Pd}$ & $70.55 \%$ & $77.29 \%$ & $2.42 \%$ \\
$\mathrm{Ag}$ & $7.55 \%$ & $8.39 \%$ & $1.77 \%$ \\
$\mathrm{Cd}$ & $0.00 \%$ & $0.00 \%$ & $1.46 \%$ \\
$\mathrm{Pt}$ & $0.00 \%$ & $0.00 \%$ & $0.56 \%$
\end{tabular}

(Surface analysis up to a depth of $\sim 1 \mu \mathrm{m}$. The $\mathrm{Cu}$ signal was a systems peak from the brass stage.)

\section{APPENDIX I: SUPPLIERS}

Alfa Aesar, 30 Bond Street, Ward Hill MA 01835, 1-978-5216300

Apiezon, M\&I Materials Ltd, PO Box 136, Manchester M60 1AN, UK

Aldrich, 1001 West Saint Paul Ave, Milwaukee WI 53233, 1-314-7715765

J.T. Baker, Mallinckrodt Baker, Inc., 222 Red School Lane, Phillipsburg NJ 08865 U.S.A., 1-908-8592151, Fax: 1-908-8596905

Keithley instruments, 28775 Aurora Rd., Cleveland OH, 44139 216-2480400.

OMEGA Engineering, P.O. Box 4047, Stamford CT 06907-0047, 1-800-6222378

Oxford Instruments, Microanalysis group, Halifax Road, High Wycombe Bucks, HP12 3SE, England, 44-(0)1494-442255. Fax 44-(0)1494-461033. 